Biológiailag aktív peptidek módosított származékainak előállítása és vizsgálata

DOKTORI ÉRTEKEZÉS

\title{
Rákosi Kinga
}

Témavezető:

Dr. Tóth Gábor

intézetvezető egyetemi tanár

Kémia Doktori Iskola

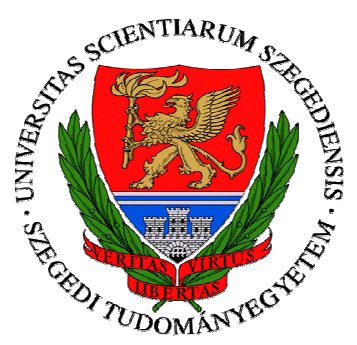

Orvosi Vegytani Intézet

SZTE TTIK

Szeged, 2010 


\section{Tartalomjegyzék}

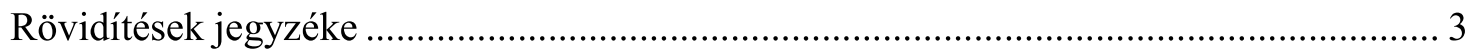

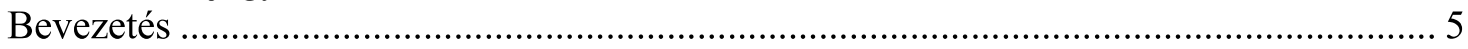

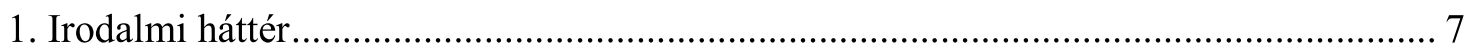

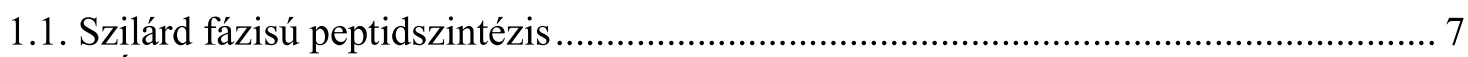

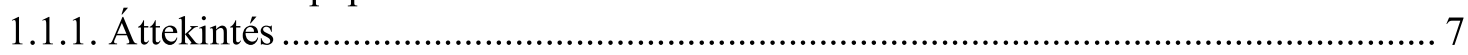

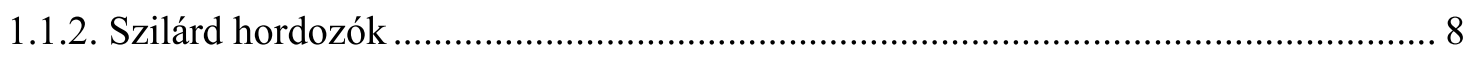

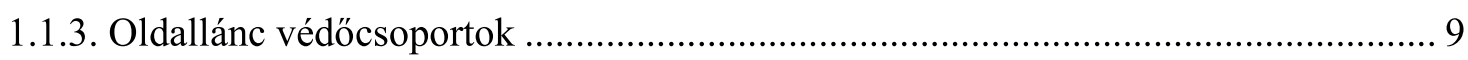

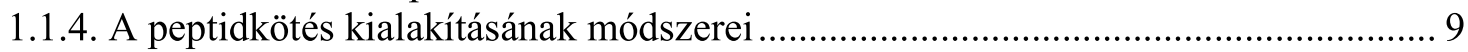

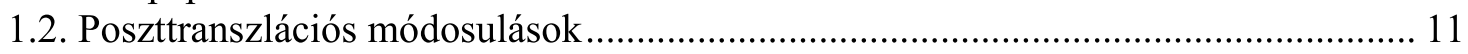

1.2.1. Diszulfid hidak a természetben és a szintetikus peptidkémiában .......................... 12

1.2.2. Fehérje foszforiláció és foszfopeptid kémia ....................................................... 15

1.3. Stresszmechanizmus és a CRF család peptidjei a stresszválaszban ......................... 16

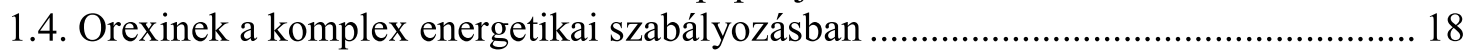

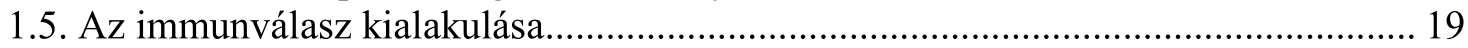

1.5.1. A Kv1.3 ioncsatorna szerepe az immunválasz szabályozásában........................... 20

1.5.2. C3a komplement eredetü peptidek az immunválasz szabályozásában .................... 23

1.5.3. A Gab1 adapter fehérje szerepe a B sejtek jelátviteli szabályozásában................. 25

1.6. Mozgékony fehérje térszerkezeti elemek konformációs egyensúlyának vizsgálata

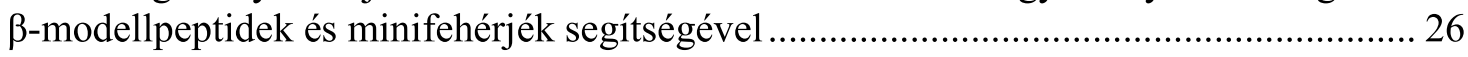

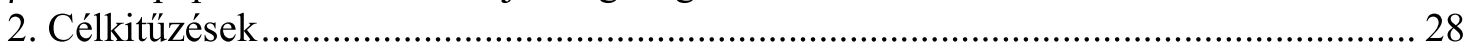

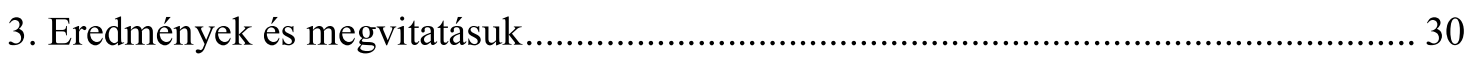

3.1. Stresszválasz szabályozás a CRF családba tartozó Ucn 3 eredetü szintetikus

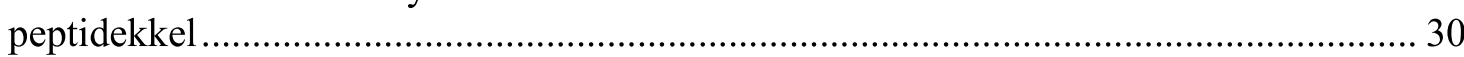

3.1.1. Antidepresszáns és szorongáscsökkentő hatású Ucn 3 és fragmenseinek előállítása

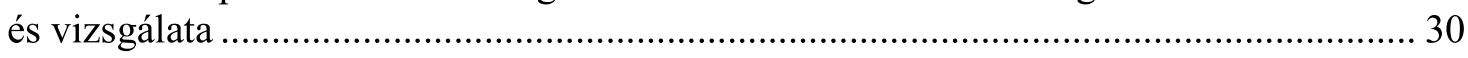

3.1.2. Antidepresszáns és szorongáscsökkentő hatású Ucn 3 analógok tervezése,

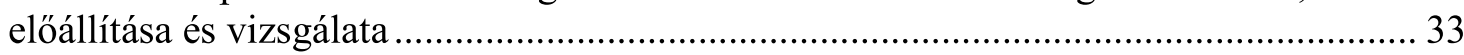

3.2. Orexinek hatása a vízanyagcserére, a vazopresszin kiválasztásra ............................ 41

3.3. Szelektív Kv1.3 ioncsatorna gátló szerek előállítása és vizsgálata......................... 46

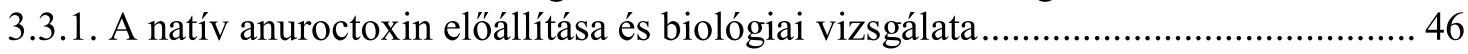

3.3.2. Növelt szelektivitású anuroctoxin mutánsok előállítása és biológiai vizsgálata .... 49

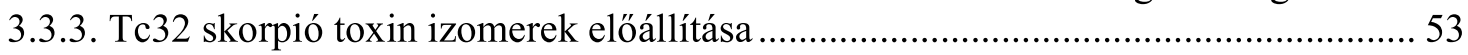

3.4. Allergiás reakció kialakulásának gátlása $\mathrm{C} 3 \mathrm{a}$-eredetü $\mathrm{C} 3 \mathrm{a} 9$ dimerekkel ................... 59

3.5. Gab1 adapter fehérje eredetű foszfopeptidek előállítása és vizsgálata a B-sejtek

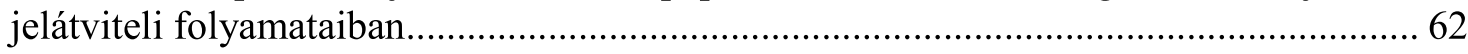

3.5.1. Gab1 eredetű foszfopeptidek és módosított származékainak előállítása ................ 63

3.5.2. Biotinilált Gab1 eredetü foszfopeptidek és módosított származékainak előállítása és

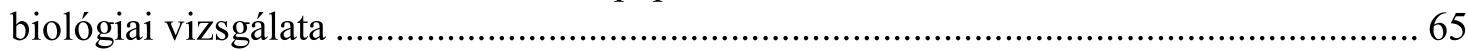

3.5.3. Sejtpermeábilis hordozó-Gab1 eredetű foszfopeptid konjugátumok előállítása és

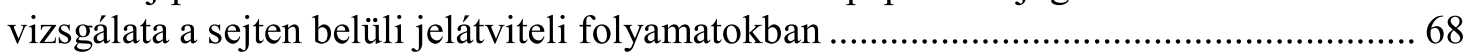
3.6. Mozgékony fehérje térszerkezeti elemek konformációs egyensúlyának vizsgálata $\beta$ -

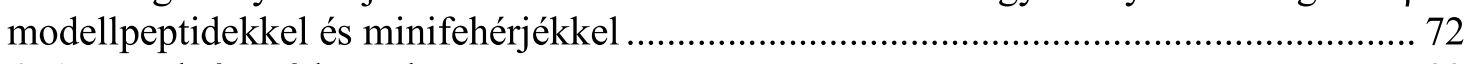

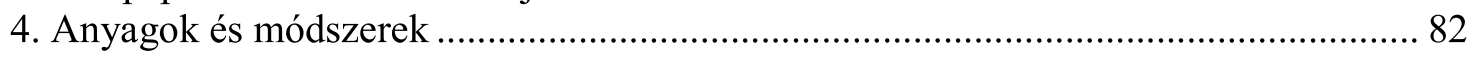




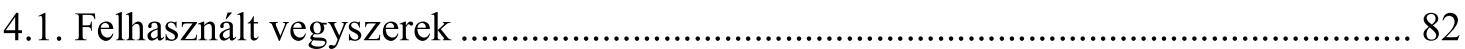

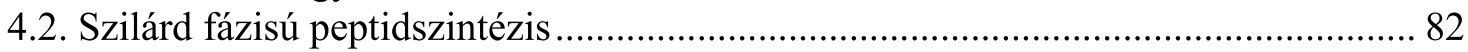

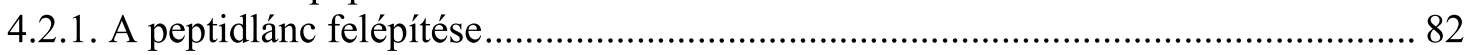

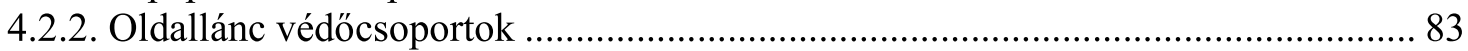

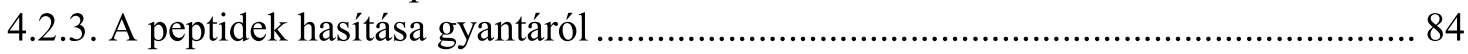

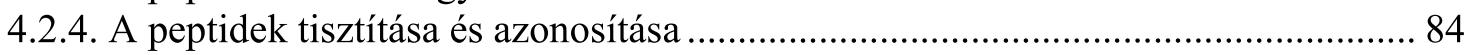

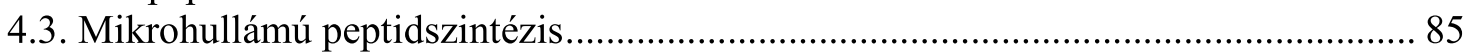

4.4. Peptidgerinc módosítást tartalmazó peptidomimetikumok előállítása ...................... 85

4.5. Foszfotirozint és foszfoszerint tartalmazó peptidek előállítása …............................... 86

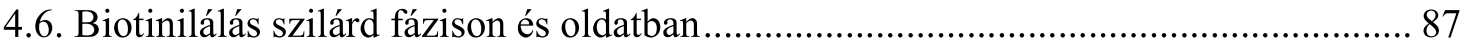

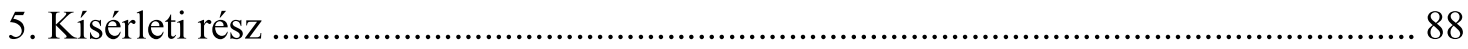

5.1. Antidepresszáns és anxiolitikus hatású Ucn 3 fragmensek és analógok előállítása .. 88

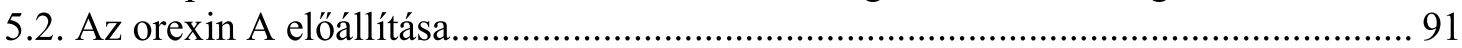

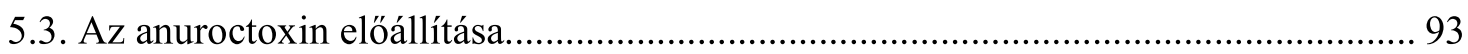

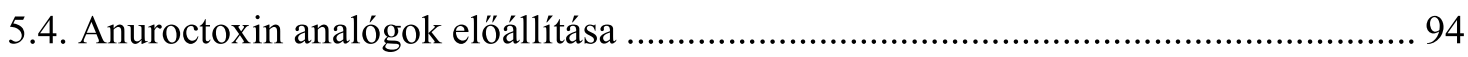

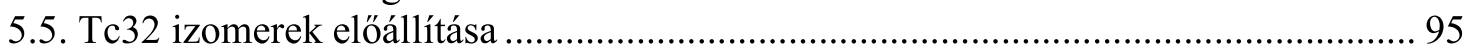

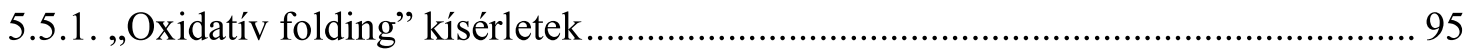

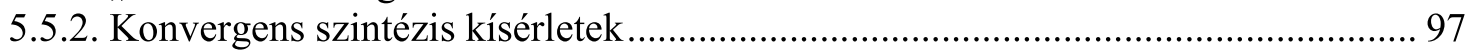

5.5.3. A lépésenkénti regioszelektív cisztein párosítások módszere ….......................... 100

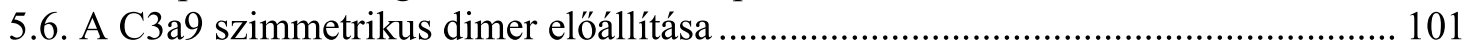

5.7. Gab1 adapter fehérje eredetű foszfopeptidek előállítása ......................................... 102

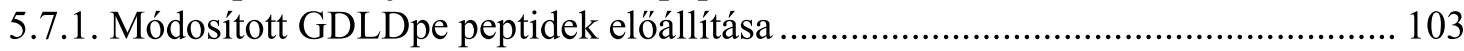

5.7.2. A Gab1 eredetű foszfopeptidek és módosított származékainak jelölése biotinnal 103

5.7.3. A sejtmembrán permeábilis Okt-R8C elóállítása .............................................. 104

5.7.4. Gab1 eredetü sejtmembrán permeábilis foszfopeptid-konjugátumok előállítása . 104

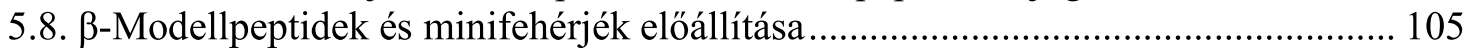

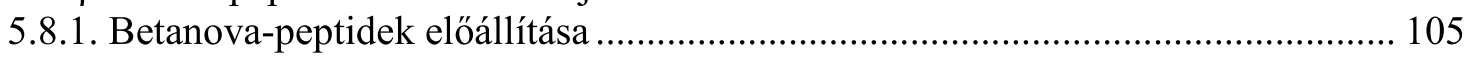

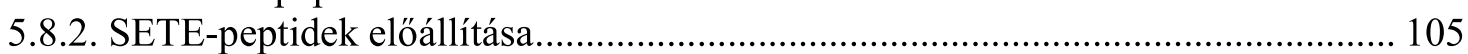

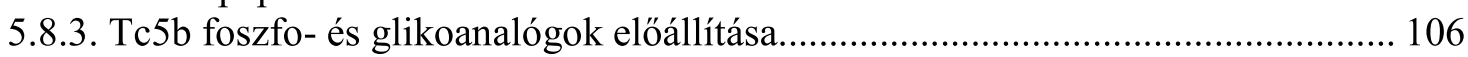

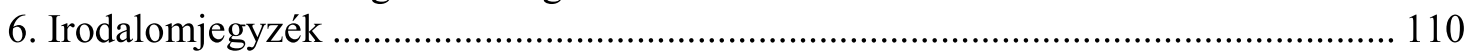

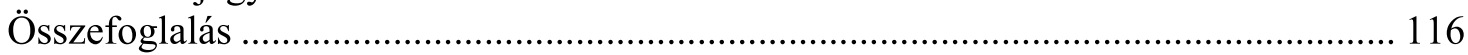

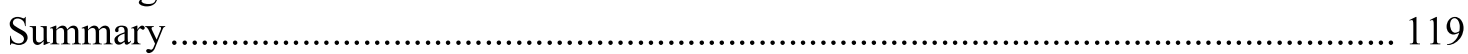

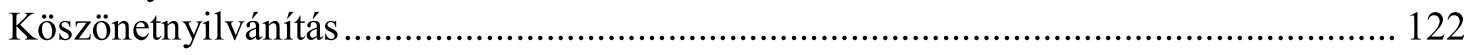




\section{Rövidítések jegyzéke}

\begin{tabular}{|c|c|}
\hline Acm- & acetamidometil- \\
\hline $\mathrm{Ac}_{2} \mathrm{O}$ & ecetsavanhidrid \\
\hline $\mathrm{AcOH}$ & ecetsav \\
\hline ACTH & adrenokortikotróp hormon \\
\hline BCR & B-sejt receptor \\
\hline $\mathrm{BL}$ & Burkitt limfóma \\
\hline Boc- & terc-butiloxikarbonil- \\
\hline Bzl- & benzil- \\
\hline $\mathrm{C} 3$ & komplement komponens 3 \\
\hline $\mathrm{CD}$ & cirkuláris dikroizmus \\
\hline CRF & kortikotróp felszabadulást segítő faktor (Corticotropin Releasing Factor) \\
\hline DCC & $N, N^{\prime}$-diciklohexilkarbodiimid \\
\hline DCM & diklórmetán \\
\hline DIEA & $N$-etildiizopropilamin \\
\hline $\mathrm{DMF}$ & $N, N$-dimetilformamid \\
\hline DMSO & dimetil-szulfoxid \\
\hline DTT & 1,4-ditio- $D L$-treitol \\
\hline ELISA & enzimhez kapcsolt immunszorbens vizsgálat \\
\hline Erk & extracelluláris szignalizáció szabályozta kináz \\
\hline ESI-MS & elektrospray ionizációs tömegspektrometria \\
\hline FceRI & high affinity IgE receptor \\
\hline Fmoc- & 9-fluorenilmetiloxikarbonil- \\
\hline Gab & Grb2 associated binder \\
\hline HATU & 7-aza-benztriazol-1-il-1,1,3,3-tetrametil-urónium hexafluoro-foszfát \\
\hline HBTU & $O$-(benztriazol-1-il)-1,1,3,3-tetrametil-urónium hexafluoro-foszfát \\
\hline $\mathrm{HF}$ & hidrogén fluorid \\
\hline HOAt & 1-hidroxi-7-aza-benztriazol \\
\hline HOBt & 1-hidroxi-benztriazol \\
\hline Ig & immunglobulin \\
\hline
\end{tabular}




$\begin{array}{ll}\text { IKCa1 } & \mathrm{Ca}^{2+} \text { aktivált } \mathrm{K}^{+} \text {csatorna } \\ \text { KHIBE } & \text { izobutil-kloroformát } \\ \mathrm{KV} & \text { feszültségfüggő } \mathrm{K}^{+} \text {csatorna } \\ \mathrm{MBHA} & \text { 4-metil-benzhidrilamin } \\ \mathrm{Meb}- & \text { 4-metil-benzil } \\ \mathrm{MeOH} & \text { metanol } \\ \mathrm{MeSiCl}_{3} & \text { metil-triklór-szilán } \\ \mathrm{NMM} & \text { N-metil-morfolin } \\ \mathrm{NOE} & \text { Nuclear Overhauser Effect } \\ \mathrm{Npys}- & \text { 3-nitro-2-piridil-szulfenil- } \\ \text {-OcHx } & \text {-ciklohexil észter } \\ \text {-O } t \mathrm{Bu} & \text {-terc-butil észter }\end{array}$

Pbf- 2,2,4,6,7-pentametil-dihidrobenzofurán-5-szulfonil-

pGlu, $<$ E piroglutaminsav

PH Pleckstrin Homology

PI3-K foszfatidilinozitol 3-kináz

RP-HPLC fordított fázisú nagyhatékonyságú folyadékkromatográfia

SH2 Src Homology 2

SHP-2 Src Homology 2 domain containing Protein Tyrosine Phosphatase

$\mathrm{St} \mathrm{Bu}-\quad$ terc-butil-szulfenil-

TEA trietilamin

$\mathrm{T}_{\mathrm{EM}} \quad$ effektor memória T-sejt

TFA trifluórecetsav

TIS triizopropil-szilán

Tos- tozil-; $p$-toluol-szulfonil-

TRC/CD3 T-sejtreceptor-CD3 komplex

Tris 2-amino-3-hidroximetil-1,3-propándiol

Trt- tritil-

Z- benziloxikarbonil-

Az aminosavak rövidítésére az irodalomban haznált egy- és hárombetüs kódokat alkalmaztam [1]. 


\section{Bevezetés}

Az előző évtized óriási teljesítménye, hogy meghatározták az ember DNSállományának elsődleges szerkezetét, a humán genom nukleotidszekvenciáját (Human Genom Program). A géneken túl viszont egy még bonyolultabb kapcsolatrendszerrel rendelkező világ, a gének által kódolt fehérjék tartománya kezdődik, amelyek közvetlenül vagy közvetett módon határozzák meg egy szervezet felépítését és funkcióját.

A sejtben a riboszómákon lezajló fehérjeszintézis után a fehérjemolekula sokféle szerkezeti változáson mehet keresztül. Gyakran találkozunk a fehérjék aminosav oldalláncának különböző utólagos - poszttranszlációs - módosulásával, melynek során a fehérje molekula egy része, például a szignálszekvencia, a transzportért felelős régió, propeptidek vagy a biológiai hatás kifejtését gátló aminosavrészek (Met) lehasadhatnak. A molekula szabad amino csoportjaira acetil- illetve metil csoportok is beépülhetnek. A hidroxilcsoportot tartalmazó aminosav oldalláncokon (Ser, Thr, Tyr) foszforsav- vagy zsírsavészterek vagy O-glikozidos kötésben szénhidrátláncok (oligoszacharidok) kapcsolódhatnak a polipeptidgerinchez. A fehérjék aszparagin aminosavat tartalmazó oldalláncához N-glikozidos kötéssel szintén különböző oligoszacharid egységek kapcsolódhatnak. A metalloproteinek valamilyen kationt tartalmaznak komplex kötésben, amelynek az esetek nagy részében közvetlen szerepe van a fehérjék funkciójának kialakításában. Mai tudásunk szerint több mint 300 különböző kémiai átalakulás mehet végbe fehérjeszintézis után a sejtben és ezek szoros összefüggésben vannak a fehérje biológiai funkciójával, illetve működésük ki- és bekapcsolásával.

A fehérjeállomány feltérképezése nagy erővel zajlik napjainkban is. A detektált és biológiai hatással ellátott fehérjék müködésének megértését, szervezetben betöltött funkciójuk teljesebb megismerését segíti a fehérjék modellezése kisebb peptidekkel. A szerkezet-hatás összefüggéseinek feldolgozásával, értékelésével megismerhetővé válnak a fehérjék aktivitásához szükséges szerkezeti elemek. A modellpeptidek, fehérjeszakaszok, biológiailag aktív peptidek, peptidomimetikumok kémiai kutatásának egyik legfőbb preparatív eszköze a szilárd fázisú peptidkémia. A szilárd fázisú peptidszintézis bevezetése óta jelentős fejlődésen ment keresztül, ugyanakkor vannak 
olyan szekvenciák, amelyek előállítása rutin módszerekkel sok nehézségbe ütközik, különösen a poszttranszlációs módosítást tartalmazó biológiailag aktív peptidek esetén.

Doktori munkám során olyan - többnyire módositott - szintetikus peptidek elöállítását tüztem ki célul, amelyekkel molekuláris szinten befolyásolhatók bizonyos biológiai folyamatok, valamint a fehérjék konformációs változásai tanulmányozhatóvá válnak. 


\section{Irodalmi háttér}

\subsection{Szilárd fázisú peptidszintézis}

\subsection{1. Áttekintés}

A peptidek szerkezete és biológiai hatása közötti összefüggések vizsgálatában du Vigneaud oxitocin szintézise [2] egy mérföldkő volt a XX. század közepén. A kezdeti oldatfázisú peptidszintézis nagy idő- és munkaigénye indította Merrifieldet a szilárd fázisú peptidszintézis elvének kidolgozására [3] (Nobel-díj; 1984).

A szilárd fázisú peptidszintézis során az aminosavak egymáshoz kapcsolása szilárd, oldhatatlan hordozón, úgynevezett gyantán történik, amelyre első lépésben a peptid C-terminálisán lévő, $N$-terminálison védett aminosavat kapcsoljuk kovalens kötéssel. A védőcsoport eltávolítása után a további védett aminosavakat ehhez a hordozóhoz kötött aminosavhoz kapcsoljuk, így a növekvő peptid a szintézis végéig a szilárd hordozón marad. A módszer nagy előnye, hogy nincs szükség lépésenkénti tisztításra, mert a gyantához kötött peptidet a szintézis folyamán egyszerủen, oldószerrel történő mosásokkal lehet elválasztani a kapcsolóreagensektől, valamint a feleslegben alkalmazott aminosav-származékoktól. A szintézis igen kevés eszközt igényel, mindössze egy üvegszürővel ellátott edényt. A módszer lehetőséget ad az automatizálására is, hiszen a szintézis azonos lépések ismétlődő ciklusából áll.

Hosszabb peptidek esetén előfordul, hogy a hibás (hiányos, vagy oldalláncvédőcsoportot tartalmazó) peptid tulajdonságai csak kis mértékben különböznek a hibátlan peptidétől. A hagyományos preparatív tisztítási módszerekkel (kirázás, kristályosítás, kromatográfiás eljárások) ezen peptideket nem, vagy csak nagyon nehezen lehet elválasztani egymástól. Ezért érthető, hogy a szilárd fázisú peptidszintézist csak a nagyhatékonyságú elválasztástechnikai módszerek kifejlődése és elterjedése után kezdték széles körben használni (pl. HPLC).

Annak ellenére, hogy a peptid szintetikus módszerek óriási fejlödésen mentek át, vannak olyan szekvenciák, amelyek előállítása rutin módszerekkel sok nehézségbe ütközik. Az utóbbi években több kutatócsoport is beszámolt a mikrohullámú technika alkalmazásával végzett peptidszintézis hatékonyságáról [4-6]. Az új technológia alkalmazása a peptidkémiában nemcsak a reakciók gyorsaságára lehet hatással, hanem a 
termékösszetételt és tisztaságot is kedvezően befolyásolhatja.

A szilárd fázisú peptidszintézis két legfontosabb alapmódszere közül az egyik esetben az $\alpha$-aminocsoportokat $t$-butiloxikarbonil (Boc) csoporttal, míg a másik esetben 9-fluorenilmetiloxikarbonil (Fmoc) csoporttal védjük [7-8]. Ezen két módszer köré fejlődött ki nagyrészt a peptidkémia három alappillérre: a szilárd hordozók kémiája, az oldallánc védőcsoportok kémiája, valamint a peptidkötést kialakító kapcsoló reagensek kémiája.

\subsubsection{Szilárd hordozók}

A peptidkémiában a szilárd hordozónak kiemelt szerep jut. A Merrifield által használt sztirol-divinil-benzol kopolimer alapú gyanták ma is a legnépszerübbek közé tartoznak [3]. A módszer fejlődésével a hordozók száma és fajtája is folyamatosan nőtt. A hordozók döntő többsége alacsony keresztkötési fokú gél típusú hordozó. Ezeknél a gyantáknál kulcsfontosságú a jó duzzadási tulajdonság. Figyelembe véve a mechanikai stabilitást és a minél magasabb duzzadási értéket is, napjainkban általánosan 1\%-os keresztkötésű kopolimereket használnak.

Munkám során Fmoc-stratégiánál Wang, TentaGel R RAM, TentaGel R PHB, valamint Rink hordozót, Boc-stratégiánál Merrifield, PAM, illetve MBHA hordozót használtam. A hordozókról való savas hasítás után a Wang, TentaGel R PHB, PAM, illetve a Merrifield hordozó karboxil $C$-terminális végződést ad, míg a Rink-amid, TentaGel R RAM, illetve az MBHA hordozó amid végződést.

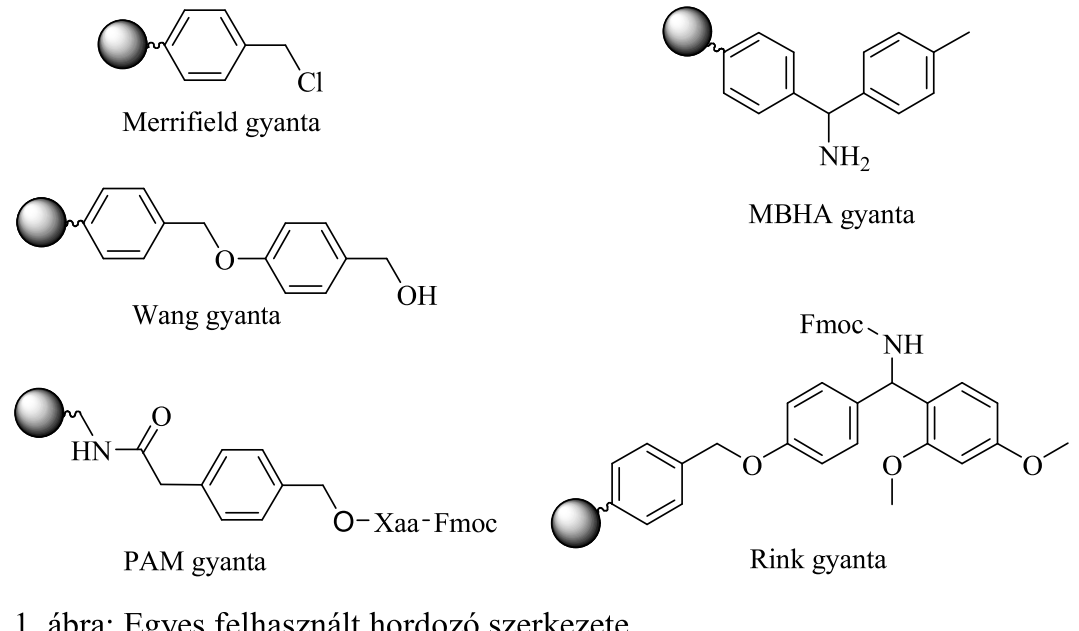

1. ábra: Egyes felhasznált hordozó szerkezete 


\subsubsection{Oldallánc védőcsoportok}

Két aminosav amino- és karboxilcsoportjának megfelelő irányú összekapcsolása csak az egyéb reaktív csoportok blokkolásával valósítható meg. A szilárd fázisú peptidszintézis során, a melléktermékek keletkezésének elkerülése végett, az összes trifunkciós aminosav oldalláncát védeni kell. Olyan oldallánc-védőcsoportokat kell használni, amelyek a Boc-, illetve Fmoc-védőcsoport lehasításakor nem, a peptidek hordozóról való lehasításakor viszont távoznak a peptidről. A szilárd fázisú peptidszintézisben két meghatározó védőcsoport kombinációt használnak $[9,10]$, a legáltalánosabban használt oldallánc védőcsoportok listáját az 1. táblázat foglalja össze.

1. táblázat: Az általánosan használt aminosavak és védőcsoportjaik

\begin{tabular}{|l|c|c|c|c|c|}
\hline \multicolumn{2}{|c|}{ Aminosav } & & $\begin{array}{c}\text { Oldallánc } \\
\text { funkció }\end{array}$ & $\begin{array}{c}\text { Boc/Bzl } \\
\text { védőcsoport }\end{array}$ & $\begin{array}{c}\text { Fmoc/tBu } \\
\text { védócsoport }\end{array}$ \\
\hline Arginin & Arg & R & guanidino & tozil & $\begin{array}{c}\text { 2,2,4,6,7-pentametil- } \\
\text { 2,3-dihidrobenzofurán-5- } \\
\text { szulfonil }\end{array}$ \\
\hline Aszparagin & Asn & N & karboxamid & & tritil \\
\hline Aszparaginsav & Asp & D & karboxil & ciklohexil-észter & terc-butil-észter \\
\hline Cisztein & Cys & C & tiol & 4-metil-benzil & tritil \\
\hline Glutamin & Gln & Q & karboxamid & & tritil \\
\hline Glutaminsav & Glu & N & karboxil & ciklohexil-észter & terc-butil-észter \\
\hline Lizin & Lys & K & amino & 2-klór-benziloxikarbonil & terc-butiloxikarbonil \\
\hline Hisztidin & His & H & imidazol & benziloxikarbonil & tritil \\
\hline Szerin & Ser & S & hidroxil & benzil-éter & terc-butil-éter \\
\hline Tirozin & Tyr & Y & hidroxil & $\begin{array}{c}\text { 2-bróm- } \\
\text { benziloxikarbonil }\end{array}$ & terc-butil-éter \\
\hline Treonin & Thr & T & hidroxil & benzil-éter & terc-butil-éter \\
\hline
\end{tabular}

\subsubsection{A peptidkötés kialakításának módszerei}

Az aminosav-származékok kapcsolása a növekvő peptidszakaszhoz többféle módon történhet. Elterjedten alkalmazzák az anhidrides (föleg oldatfázisban), aktív észteres, karbodiimides ( $N, N^{\prime}$-diciklohexilkarbodiimid, ill. $N, N$ '-diizopropilkarbodiimid) acilezést is [11]. Az anhidrid nem minden esetben stabil, tehát csak közvetlenül a kapcsolási reakció előtt célszerü elkészíteni. A vegyes anhidridek alkalmazása esetén az anhidrid két irányban lehetséges felnyílása mellékreakcióhoz vezethet, de legtöbb esetben ennek mértéke elhanyagolható.

Gyakran használják a védett aminosavak aktivált észtereit, melyek általában stabil, kristályos vegyületek, így előre elkészíthetők és jól tárolhatók. A védett 
aminosavak elektronvonzó csoportokkal szubsztituált fenilészterei általában az anhidrideknél lassabban reagálnak, de a pentafluor-fenil-észter [12], különösen 1-hidroxibenztriazol $(\mathrm{HOBt})$ jelenlétében a szimmetrikus anhidridhez hasonló reaktivitású. Az aminosavak 1-hidroxi-benztriazollal kialakított aktív észtereinek használata is gyakori, az észterkötést gyakran karbodiimid reagenssel alakítják ki in situ, közvetlenül a kapcsolás előtt, és izolálás nélkül használják fel, mert nem stabil. A HOBt helyett Carpino a hatékonyabb kapcsolást lehetővé tévő 1-hidroxi-7-azabenztriazolt (HOAt) javasolja az aktív észter kialakítására [13].

A későbbiekben a benztriazol foszfónium- és urónium-származékaira terelődött a figyelem, melyeknek általában hexafluoro-foszfát vagy tetrafluoro-borát sóit használják: $O$-(benztriazol-1-il)-1,1,3,3-tetrametil-urónium hexafluoro-foszfát (HBTU), 7-azabenztriazol-1-il-1,1,3,3-tetrametil-urónium hexafluoro-foszfát (HATU). A kapcsolás során az aminosav benztriazol észtere, illetve aza-benztriazol-észtere az acilező reagens. Carpino és munkatársai az aza-benztriazol alapú reagenseket találták a leghatékonyabbnak peptidszintézisben, az acilezési reakció szomszédcsoport-részvétellel megy végbe [14].

A kereskedelmi forgalomban megjelent legújabb kapcsolóreagensek az Oxyma [etil-(hidroxi-imino)cianoacetát], illetve a hasonló vázra épülő COMU [1-ciano-2-etoxi2-oxoetilidénaminooxi)-dimetilamino-morfolino-karbénium hexafluorofoszfát], melyek a HOBt, illetve a HATU lehetséges helyettesei $[15,16]$.<smiles>On1nnc2ccccc21</smiles>

$\mathrm{HOBt}$<smiles>CN(C)C(On1nnc2ccccc21)=[N+](C)C</smiles>

HBTU (TBTU)<smiles></smiles><smiles>CN(C)C(On1nnc2cccnc21)=[N+](C)C</smiles>

HATU<smiles>CCOC(=O)C(C#N)=NO</smiles><smiles>CCOC(=O)/C(C#N)=N/OC(N1CCOCC1)=[N+](C)C</smiles>

2. ábra: Néhány kapcsolószer szerkezete 


\subsection{Poszttranszlációs módosulások}

A transzláció során szintetizált fehérjeláncok jelentős része további reakciók során nyeri el végső, biológiailag aktív formáját [17]. Ezeket a transzlációt követő, fehérjeláncot érintő reakciókat összefoglalóan poszttranszlációs módosulásoknak nevezzük, amelyeken mind a prokarióta, mind az eukarióta sejtek fehérjéi keresztülmennek.

A módosulások egy része, például a szignálszekvenciák lehasadása, az előfehérjék proteolítikus hasítása nem igényel kofaktort. A módosulások nagyobb része azonban kofaktorigényes folyamat, a sorból néhány folyamatot kiragadva: egyes fehérjék szerin, treonin és tirozin részei foszforilálódnak (kofaktorként ATP-t igényelve); több véralvadási faktor aszparaginsav és glutaminsav részletei további karboxil csoportokkal egészülnek ki (kofaktorként K-vitamint igényelve); izomfehérjék és a citokróm C lizin részletei metilálódhatnak (kofaktorként $N$-adenozil-metionint igényelve). A kollagének fő szerkezetalkotója a hidroxiprolin aszkorbinsavat igénylő folyamat révén jut hozzá hidroxil csoportjához. A glikoproteinek is poszttranszlációs módosulásuk során nyerik szénhidrát oldalláncukat. Több bakteriális és eukarióta fehérje igényel aktivitásához kovalensen kötött prosztetikus csoportot. Ezen csoportok is a fehérjelánc riboszómáról történő távozása után épülnek be. Példaként említhetjük a kovalensen kötött biotint az acetil-CoA karboxiláz esetében, valamint a hem csoportot a citokróm $\mathrm{C}$ esetében. $\mathrm{Az}$ exportra kerülő fehérjékben gyakran alakulnak ki kovalens diszulfid kötések láncközi és láncok közötti cisztein részletek között natív konformációjuk kialakulásakor. Az így kialakult diszulfid kötések segítenek a natív fehérjeszerkezet megőrzésében az intracelluláristól különböző viszonyok között.

A poszttranszlációs módosulások hatása fehérjék szerkezetére és természetben betöltött szerepére régóta a fehérjekutatás középpontjában áll, azonban ennek tanulmányozása szintetikus fehérjék segítségével sok nehézségbe ütközik ha csak méretüket és jellegüket tekintjük is, ezért oly fontos a módosított peptidek, mint módosított minifehérjék szintézise. 
1.2.1. Diszulfid hidak a természetben és a szintetikus peptidkémiában

A diszulfid híd kovalens kötés, mely két cisztein tiol csoportja között alakul ki. A természetben csak ritkán alakulnak ki intracelluláris fehérjékben. Ezen ritka esetekben is legtöbbször egyes enzimek katalitikus, tranziens állapotában jönnek létre, vagy enzimregulációs szerepet töltenek be. Az előzőekkel ellentétben gyakran megtalálhatóak szekréciós fehérjékben, elengedhetetlenek a megfelelő struktúra kialakulásához és stabilizálják a megfelelő szerkezetet. Egyenlőtlen eloszlásuk az intra- és extracelluláris fehérjék között az eltérő redox viszonyokkal magyarázható [18].

A diszulfid hidak kialakulása tulajdonképpen egy oxidációs folyamat. Az élő szervezetekben zajló diszulfid képződés szigorúan katalizált és ellenőrzött folyamat, amely a „diszulfid donor” (elektronakceptor) és a célfehérje (elektrondonor) közti tioldiszulfid csere során jön létre. Tehát ezen reakciók során nettó diszulfid kötések nem képződnek és nem bomlanak fel, egyszerüen csak kicserélődnek, átvándorolnak két tiolpár között.

Amíg egy fehérje csak két cisztein tiolt tartalmaz, a kialakuló diszulfid híd csak ezen két aminosavrészlet között jöhet létre. A három vagy több cisztein tiolt tartalmazó fehérjeláncokban fennáll a lehetősége, hogy a diszulfid híd nem a megfelelő ciszteinek között alakul ki. Ezen hibásan kialakult diszulfid kötések elektron transzfert nem kívánó átrendeződés során izomerizálódhatnak, felvéve a helyes konformációt.

A diszulfid hidak evolúciósan konzervált szerkezeti motívumok. Sok biológiailag aktív peptid és protein (hormonok, enzimek, növekedési faktorok, toxinok, immunglobulinok) több diszulfid híd által stabilizált szerkezettel rendelkezik, ezek lehetnek intra- vagy intermolekulárisak. A szintetikus peptidkémia egyik régi kihívásának számít ezen cisztein-tartalmú peptidek szintézise, föként a többszörös, regioszelektív diszulfid hidak kialakitásánál felmerülő nehézségek miatt (pl. egy 3 diszulfid hidat tartalmazó molekulánál 75 izomer keletkezhet - 15 egy, 45 két, illetve 15 három diszulfid hidat tartalmazó izomer) [19, 20].

A főbb szintézisstratégiák [21] így összegezhetőek:

i) lépésenkénti regioszelektív cisztein párosítások;

ii) konvergens stratégiák, amelyek kombinálják a kisebb cisztein tartalmú származékok statisztikus oxidációját a regioszelektív diszulfid képzéssel; 
iii) „oxidatív folding”;

iv) szelenocisztein segítségével irányított diszulfid hidak kialakítása.

A peptidkémiában leginkább használt tiol védőcsoportokat a 2. táblázat mutatja be [22].

2. táblázat: Néhány tiol védőcsoport

\begin{tabular}{|c|c|c|c|}
\hline Védőcsoport & Szerkezet & Stabilitás & Eltávolítás \\
\hline 4-metilbenzil (Meb) & & $\begin{array}{l}\text { TFA, } \operatorname{Ag}(\mathrm{I}) \text {, } \\
\text { bázis, } \mathrm{RSCl}\end{array}$ & $\begin{array}{l}\mathrm{HF}\left(0^{\circ} \mathrm{C}\right), \mathrm{Tl}(\mathrm{III}) \\
\mathrm{Ph}_{2} \mathrm{SO} / \mathrm{MeSiCl}_{3}\end{array}$ \\
\hline 4-metoxibenzil (Mob) & & $\begin{array}{l}\text { TFA, } \mathrm{I}_{2}, \\
\text { bázis, RSCl }\end{array}$ & $\begin{array}{l}\mathrm{HF}\left(0^{\circ} \mathrm{C}\right), \mathrm{Ag}(\mathrm{I}) \\
\mathrm{Hg}(\mathrm{II}), \mathrm{Tl}(\mathrm{III}) \\
\mathrm{Ph}_{2} \mathrm{SO} / \mathrm{MeSiCl}_{3}\end{array}$ \\
\hline terc-butil $(t \mathrm{Bu})$ & & $\begin{array}{l}\text { TFA, } \\
\text { HF }\left(0{ }^{\circ} \mathrm{C}\right) \text {, } \\
\text { bázis }\end{array}$ & $\begin{array}{l}\mathrm{HF}\left(20^{\circ} \mathrm{C}\right), \mathrm{Hg}(\mathrm{II}), \mathrm{RSCl} \\
\mathrm{Ph}_{2} \mathrm{SO} / \mathrm{MeSiCl}_{3}\end{array}$ \\
\hline acetamidometil (Acm) & & $\begin{array}{l}\text { TFA, HF } \\
\text { (részben), } \\
\text { bázis, RSCl }\end{array}$ & $\begin{array}{l}\mathrm{I}_{2}, \mathrm{Ag}(\mathrm{I}), \mathrm{Hg}(\mathrm{II}), \mathrm{Tl}(\mathrm{III}) \\
\mathrm{Ph}_{2} \mathrm{SO} / \mathrm{MeSiCl}_{3}, \mathrm{RSCl}\end{array}$ \\
\hline $\begin{array}{l}\text { terc-butil-szulfenil } \\
(\mathrm{S} t \mathrm{Bu})\end{array}$ & & $\mathrm{HF}$ & $\begin{array}{l}\mathrm{RSH}, \mathrm{Bu}_{3} \mathrm{P},\left(\mathrm{HOOC}-\mathrm{CH}_{2}-\right. \\
\left.\mathrm{CH}_{2}\right)_{3} \mathrm{P}\end{array}$ \\
\hline $\begin{array}{l}\text { 3-nitro-2-piridil- } \\
\text { szulfenil (Npys) }\end{array}$ & & $\begin{array}{l}\text { bázis, } \\
\text { nukleofilok }\end{array}$ & $\begin{array}{l}\mathrm{RSH}, \mathrm{Bu}_{3} \mathrm{P},\left(\mathrm{HOOC}-\mathrm{CH}_{2^{-}}\right. \\
\left.\mathrm{CH}_{2}\right)_{3} \mathrm{P}\end{array}$ \\
\hline trifenil-metil (Trt) & & $\begin{array}{l}\text { bázis, } \\
\text { nukleofilok }\end{array}$ & $\begin{array}{l}\text { híg TFA/gyökfogó, } \mathrm{I}_{2}, \mathrm{Tl}(\mathrm{III}) \text {, } \\
\mathrm{Ag}(\mathrm{I}), \mathrm{Hg}(\mathrm{II}), \mathrm{RSCl}\end{array}$ \\
\hline 4-metoxitritil (Mmt) & & $\begin{array}{l}\text { bázis, } \\
\text { nukleofilok }\end{array}$ & $\begin{array}{l}\text { híg TFA/gyökfogó, } \mathrm{I}_{2}, \mathrm{Tl}(\mathrm{III}) \text {, } \\
\operatorname{Ag}(\mathrm{I}), \mathrm{Hg}(\mathrm{II})\end{array}$ \\
\hline 9-fluorenilmetil (Fm) & & $\mathrm{HF}, \mathrm{I}_{2}$ & bázis \\
\hline 9H-xanten-9-il (Xan) & & $\begin{array}{l}\text { bázis, } \\
\text { nukleofilok }\end{array}$ & híg TFA/gyökfogó, I 2, Tl(III) \\
\hline
\end{tabular}

A módszerek mindegyike megköveteli a lineáris szekvencia szintézisét szilárd

fázison, amelyhez elengedhetetlen a megfelelő védőcsoport-séma előzetes megválasztása. 
Az oxidáció történhet a szilárd hordozón vagy oldatban, a legáltalánosabban az oldat fázisú oxidációt használják.

A regioszelektív módszert általában egy vagy két, maximálisan három intra- vagy intermolekuláris diszulfid hidat tartalmazó molekulák esetén használják [23, 24], hiszen meglehetősen nagy kémiai kontrollt igényel a folyamat, nagyon alacsony a szintézis hatásfoka, alkalmazása azonban elengedhetetlen heterodimerek szintézisénél [25-27].

A védőcsoportok nagy száma ellenére, kevés teljesíti az ortogonalitás követelményeit ami az általános szintézis stratégiákat (Boc/Bzl, Fmoc/tBu), a kölcsönös szelektivitást illeti. A legtöbb tiol-védőcsoport savérzékenysége eleve kizárja a Boc/Bzl kémiát, így kombinatorikus szempontból mindenképpen a Fmoc/tBu kémia enged nagyobb variációs lehetőségeket. A módszer hátránya, hogy az ismétlődő piperidines kezelések komoly mellékreakciókhoz vezethetnek, mint a racemizáció vagy $\beta$-elimináció.

A legáltalánosabban használt módszer az „oxidatív folding” (a molekula térszerkezetének oxidációs reakcióval történő kialakítása). Ez azt feltételezi, hogy ha biztosítjuk a megfelelő reakciókörülményeket: peptid-koncentráció, oxidálószer, $\mathrm{pH}$, hőmérséklet, a megfelelő vizes/szerves oldószer-, akkor kiaknázhatjuk a peptidszekvenciában kódolt felcsavarodási információkat és ezzel elérhetjük a natív szekvenciához hasonló szerkezetet. A módszer viszonylag egyszerünek tekinthető, hiszen csak egyfajta tiol védőcsoportra van szükségünk, a felcsavarodás elérhető a reakciókörülmények sokszínű változtatásával [28-31].

A leggyakrabban bázikus pufferben feloldják a lineáris peptidet és levegőn kevertetik. Oxidálószer hozzáadásával gyorsítható a folyamat, így általában redox puffert, dimetil-szulfoxidot [32], kálium hexa-cianoferrátot(III) vagy jódot [33] használnak. A legújabb oxidáló közegek közé tartoznak a különböző C2-, illetve C4-szubsztituált imidazolinium tartalmú ionos oldatok [34] (pl. [C2mim][OAc]), valamint a szilárd hordozóra kötött oxidálószerek, mint például a Clear-ox ${ }^{\mathrm{TM}}$ gyanta [35].

A cisztein gazdag peptidek szintézisére nincs általánosan alkalmazható módszer, azonban a létező stratégiák valamelyikének megfelelő optimalizálásával szép eredmények érhetőek el. 


\subsubsection{Fehérje foszforiláció és foszfopeptid kémia}

A sejtélettani folyamatok egyik legáltalánosabb és egyben legfontosabb reverzibilis szabályozási módja a fehérje-foszforiláció folyamata [36]. Emlős sejteken végzett ${ }^{32} \mathrm{P}$ foszforizotópos vizsgálatok alapján a celluláris fehérjék mintegy harmadánál jellemző ez a transzlációt követő kovalens módosítás. A kinázok által katalizált foszforiláció, illetve az ellentétes szerepű foszfatázok által irányított defoszforiláció lényeges szerepet játszik a növekedés és differenciáció szabályozásában, a sejtciklus, az alakváltozás, a metabolizmus, az apoptózis, a transzkripció kontrolljában és az intracelluláris jelátvitel szabályozásában [37].

A fehérjék foszforilációja túlnyomó többségében a szerin és treonin aminosavak oldalláncain történik. A tirozin foszforilációja mindössze néhány százalékot tesz ki a teljes fehérje-foszforilációs mintázatban, szerepe mégis kiemelt jelentőséggel bír, ugyanis mintegy tíz százalékos eltérés a normál, egyensúlyi értéktől elegendő lehet a sejt rosszindulatú transzformációjának a megindításában, illetve egyéb kóros mủködés kialakításában.

A szintetikus foszfopeptidek felhasználhatók foszforiláció vagy defoszforiláció hatására végbemenő esetleges konformációs változások tanulmányozására, illetve az egyes foszforilációs folyamatokban résztvevő kinázok ismeretében közelebb kerülhetünk az immunrendszer müködésének megértéséhez. Mégis csak az 1980-as években jelentek meg az első közlemények ilyen származékok előállításáról. Ennek oka részben a foszfát beépítés problémáiban, részben a foszfopeptid szintézis során fellépő mellékreakciókban keresendő.

A foszfopeptidek szintézisére két fo stratégia ismeretes: a „synthon” és a globális módszer [38, 39]. A „synthon” megközelítés lényege, hogy a peptidláncba a kész foszforilált aminosavat építjük be. A globális módszernél az oldallánc védőcsoport nélküli Ser/Thr/Tyr-t tartalmazó kész peptidet utólag foszforiláljuk [40]. A globális módszer egyik módosított változata is ismeretes, amely tulajdonképpen ötvözi a két stratégia lényegét és tapasztalataink szerint a legjobb eredménnyel is alkalmazható: az ún. „online” módszer - lényege, hogy a Ser/Thr/Tyr-t oldallánc védőcsoport nélkül építjük be és a beépítés után közvetlenül alakítjuk ki a foszfátésztert. Ez általában két lépésben történik: az első a foszfitilálás vagy foszfonálás és ezt követi egy oxidációs lépés [41]. 
Az elméletileg szóba jöhető reagensek közül a foszfokloridát módszer jó eredményt ad szerint vagy treonint tartalmazó peptideknél, de tirozinnal nem. A polifoszforsav jó eredménnyel képez foszfát-észtert, de tirozinból csak megemelt hőmérsékleten, amely körülmények között a peptidkötés nem stabil. Foszforilált synthonok előállítására viszont ez alkalmazható módszer. A kapott védetlen foszforsavat tartalmazó vegyület felhasználhatósága azonban mellékreakciók miatt korlátozott. A szerin, ill. treonin tulajdonképpen jóval könnyebben foszforilálódik, mint a tirozin, de a foszfát beépítést követően végzett védőcsoport eltávolítások során a védett foszfátcsoport eliminációjával és reaktív dehidro-peptidek képződésével találkozhatunk. A foszfopeptidek szintézisére a III vegyértékü foszfor megfelelő származékai, a foszforamiditek tünnek szinte kizárólag alkalmasnak. Sajnos a foszforamiditek szintézise gyakran nehézkes, érzékenyek oxidációra, valamint bomlékonyak is [41, 42]. A $H$-foszfonátokat (foszforsav monoésztereket) már régóta ismerik a nukleinsav kémiában. A $H$-foszfonátok a foszforamiditekhez hasonló reaktivitással rendelkeznek [43, 44]. A kapcsolás után kapott $H$-foszfonát oxidációja a megfelelő, részlegesen védett peptidfoszfát-észterhez vezet. E reagens előnyei: lényegesen stabilabb, kevésbé érzékeny nedvességre ill. oxidációra [45].

\subsection{Stresszmechanizmus és a CRF család peptidjei a stresszválaszban}

Az élő szervezet sajátossága, hogy képes változással reagálni a környezetéből, illetve a saját biológiai rendszeréből érkező kihívásokra. Ezek a külső fizikai és szociális tér, vagy belső élettani paraméter megváltozását jelentik. Lehetnek az egyed számára pozitívak vagy negatívak, de mindenképp fontosak és homeosztatikus, illetve viselkedéses választ igényelnek. A válasz többnyire összetett, több szervrendszert magába foglaló reakció.

Bár a különféle sztresszorok eltérő szenzoros és feldolgozó rendszereket mozgósítanak az agyban, minden esetben elérik a stresszválasz „végső közös útját” jelentő hipofizeotróp parvocelluláris neuronokat a hipotalamusz paraventrikuláris magjában. Ez a sejtcsoport szabályozott módon kortikotropin felszabadító hormont (CRH) és vazopresszint juttat az agyalapi mirigy portális keringésébe, ezzel fokozza az adenohipofízis ACTH-elválasztását és végső soron a mellékvesekéreg glükokortikoid felszabadulását [46]. 
Az emlösök többségében a CRH, másképpen CRF- kortikotropin felszabadító faktor, az elsődleges ACTH-szekretagóg anyag [47]. A CRF 41 aminosavból álló egyláncú polipeptid, amely egy hosszabb prekurzor molekulából, 196 aminosav hosszúságú pre-pro-CRF-ből enzimatikusan hasítódik ki. Az utóbbi években további három neuropeptidet fedeztek fel, amelyek mintegy 45\%-os szekvenciaegyezést mutatnak a CRF-ral: az urokortin I (Ucn 1), urokortin II (Ucn 2) és urokortin III (Ucn 3) [48, 49]. Az eddigi vizsgálatok két receptort azonosítottak, amelyek felelősek a CRF biológiai hatásaiért. Mindkét CRF-receptor serkentő G-proteinhez kapcsolt membránfehérje, amely az adenilát-cikláz-cAMP-PKA szignáltranszdukciós útvonalat használja a célsejtben.

Az 1. típusú CRF-receptor (CRF-R1) nagy affinitással köti a CRF-t. Elsősorban az adenohipofízis kortikotróp sejtjein található, de az agy számos területén kimutatható [50]. A CRF hatását a CRF-R1 receptoron keresztül fejti ki, aktiválja az ACTHmellékvesekéreg rendszert és fokozza a mellékvesekéreg kortikoszteroid szekrécióját, ugyanakkor felelős a stressz-aktiválásához kapcsolódó szorongás (anxiogenitás) hatásáért is. A CRF-R1 tehát a stressz mechanizmus aktiválását közvetíti és anxiogén. A CRFhatás szabályozásának extracelluláris tényezője az ún. CRF-kötő fehérje (CRF-Binding Protein). Affinitása a CRF iránt egy nagyságrenddel nagyobb, mint a CRF-R1-nek. A kötőfehérje csökkenti a CRF elérhetőségét a receptora számára, ugyanakkor az agyi extracelluláris CRF-kötő kapacitás növelése (pl. krónikus stressz során) egy lehetséges kiegyenlítő válasz, amely csökkentheti a CRF-receptorok deszenzitizációját.

Számos kísérletes és klinikai megfigyelés szól amellett, hogy a CRF-rendszer zavara hozzájárul néhány pszichiátriai kórkép (pl. depresszió, szorongásos betegségek) kialakulásához.

A 2. típusú CRF-receptor (CRF-R2) kisebb affinitást mutat a CRF iránt, mint a CRF-R1, ugyanakkor nagy affinitással köti az urokortinokat. CRF-R2-t legnagyobb sürüségben a laterális szeptum, a BNST (bed nucleus stria terminalis) és az amigdala kortikális magjában mutattak ki. Az Ucn 1 mindkét receptorhoz, az Ucn 2 többnyire a CRF-R2-hoz, míg az Ucn3 kizárólagosan a CRF-R2-hoz kötődik. A CRF-R2 bizonyítottan anxiolitikus (szorongásoldó) hatást fejt ki függően a tesztelés idejétől és képes visszaszorítani a CRF-R1 stimulálását [51]. 
Az Ucn3 egy 38 aminosavból álló peptid, mely a hipotalamuszban és az amigdalában fordul elő nagyobb mennyiségben és specifikus ligandumja a CRF-R2-nak. Az Ucn3-CRF-R2 fokozza a szerotonin (5-HT) kiáramlását a bazolaterális amigdalából, erőteljesen fokozza a depressziós tesztben az antidepressziós aktivitást, ami arra a következtetésre vezetett, hogy a CRF-R2 aktiválás az endogén szerotonin kiáramlás fokozásán keresztül fejtheti ki hatását [52]. Tehát bármely gyógyszer amely képes szelektíven serkenteni a CRF-R2 müködését, potenciálisan anxiolitikus hatású, ellenkezőleg: a CRF-R2 antagonisták félelmi és depresszív magatartási reakciót képesek kiváltani.

Doktori munkám során Ucn 3, valamint ezen szekvencia célzott rövidítésével kapott fragmensei, illetve analógjai kerültek tervezésre, előállításra és tesztelésre, mint potenciális farmakonok depresszió és szorongás kezelésében.

\subsection{Orexinek a komplex energetikai szabályozásban}

Az orexinek képződése a laterális hipotalamuszban történik, receptorai az egész agyban megtalálhatóak. Az elmúlt évek számos vizsgálata bizonyította az orexineknek a szervezetben betöltött fontos szerepét [53]. Hatással vannak: az alvás-ébrenlétre, a testhőmérsékletre, az étvágyra, az energiaháztartásra, a neuroendokrin rendszer müködésére, az éberség fenntartására táplálkozás közben, az urinális és gasztrointesztinális funkciókra. Mindössze 10-20000 sejt képes ezt a speciális molekulát termelni. Az orexin sejtek elpusztulása feltehetőleg autoimmun eredetü lehet.

A két leginkább tanulmányozott terület: az orexin hatása az alvásra, valamint az étvágyra [54, 55]. Megfigyelték, hogy orexin adagolásra az éberség tartama, mértéke nő, a 2. stádiumú alvás mennyisége csökken, a REM alvás (gyors szemmozgásokkal járó alvás) mennyisége csökken. Ezeket a hatásokat az orexin a bazális előagyban és az agytörzsben levő receptorain keresztűl fejti ki. Az orexinek: direkt étvágykeltők, mozgásfokozók; az orexin expressziót fokozza az éhezés és a hipoglikémia; az orexin receptor antagonisták gátolják a táplálékfelvételt; az orexin knock-out egerek étvágytalanok. 
Doktori munkám során a két diszulfid híddal stabilizált orexin A szintézisének optimalizálását tüztem ki célul, hogy állatkísérletekben (patkányban) az orexin hatását vizsgáljuk a vízanyagcserére és a vazopresszin kiválasztásra.

\subsection{Az immunválasz kialakulása}

Az embert megtámadó idegen anyagok - antigének, szervezetbe jutásuk után a természetes immunrendszer elemeivel találkoznak először. Az ilyenkor azonnal müködésbe lépő pusztító mechanizmusokban egyrészt különböző sejtek - köztük makrofágok, természetes ölősejtek és hízósejtek -, másrészt különböző oldékony faktorok - a komplementrendszer, citokinek, antibakteriális fehérjék - vesznek részt. E veleszületett funkciók gyors aktiválódása azt eredményezi, hogy a káros anyagok jelentős része rövid időn belül elpusztul, így nem indulhat meg korlátlan elszaporodásuk. Emellett a nagyon fontos funkció mellett a természetes immunitás elemeinek döntő szerepük van az adaptív immunválasz megindításában, irányának meghatározásában is. Ezt a funkciót elsősorban a makrofágok és a nyúlványos, ún. dendritikus sejtek közvetítik, de a többi tényező (komplementrendszer, hízósejtek, természetes ölő-(NK)-sejtek stb.) szerepe sem elhanyagolható. A makrofágok és a dendritikus sejtek elsődleges szerepe a kórokozó felvételét követően az idegen struktúra finom részleteinek bemutatása az adaptív immunrendszer kulcsszereplői, a limfociták számára. Ez utóbbi sejtek aktiválódása vezet el a nagymértékü fajlagosságot és immunológiai memóriát is biztosító adaptív immunválasz kialakulásához [56].

A szerzett immunitás kulcsszereplői a T- és B-limfociták, valamint azok termékei: az ellenanyagok és limfokinek. Az antigén-felismerő receptorral rendelkező limfociták két fő típusa ismert: az ún. B- és T-sejtek. Az adaptív immunválasz beindítása e sejtek, közülük is elsősorban a T-limfociták egy csoportjának, az ún. segítő T-sejteknek az aktiválódása nélkül nem történik meg. Ehhez azonban feltétlenül szükség van a természetes immunrendszer sejtjeire, mindenekelőtt az ún. hivatásos antigén-prezentáló sejtek közé tartozó dendritikus sejtekre és a makrofágokra, amelyek képesek bemutatni az általuk felismert, majd bekebelezés után lebontott idegen anyag bizonyos részeit a megfelelő fajlagosságú receptort hordozó T-sejt számára. Ezt az ún. antigén-bemutatási folyamatot követi az eredetileg csak kis számban jelenlevő fajlagos T-sejtek klonális osztódása, majd hatékony effektorsejtekké való differenciálódása. 
A természetes immunrendszer azonban nem csak az adaptív immunválasz beindításában játszik elengedhetetlen szerepet. Az idegen anyagok szervezetből való eltávolításához ismét feltétlenül szükség van a makrofágokra, granulocitákra, valamint a számos enzim kaszkádját magába foglaló ún. komplementrendszerre. Fontos megjegyezni, hogy a nagyfokú fajlagosságot és immunológiai memóriát biztosító adaptív rendszer nem működhet a természetes immunrendszer elemei nélkül, a kettő egymásra épülve, összefonódva tartja fenn a magasabb rendủek immun-homeosztázisát.

Annak érdekében, hogy minél jobban megértsük immunrendszerünk müködését, nagyon fontos megismerni azokat a tényezőket és mechanizmusokat, amely a két rendszer közötti kapcsolat kialakításában szerepet játszanak.

Doktori munkám során a két rendszer közötti különböző jelátviteli folyamatokra szelektíven ható szintetikus peptidek előállítása volt a cél, amelyek szelektivitásuk révén különböző immunológiai betegségekre ható gyógyszerkészítmények fejlesztésének alapját képezhetik.

1.5.1. A Kv1.3 ioncsatorna szerepe az immunválasz szabályozásában

Az adaptív immunrendszer sejtjeinek zömét a T- és B-limfociták alkotják. Ezen sejtek legfőbb jellemzője, hogy antigéneket fajlagosan felismerni képes receptorokat hordoznak a felszínükön. Az antigénnel közvetve (T-sejt) vagy közvetlenül (B-sejt) kölcsönhatásba kerülő sejtek aktiválódnak. Az aktiválódás eredményeképpen a sejtek osztódnak, majd effektor sejtekké és hosszú életű emlékezősejtekké differenciálódnak. A T-sejt receptor (TCR/CD3 komplex) stimulációját követően a limfociták akkor is osztódnak, ha a kezdeti stimulust megszüntetjük [57]. Egy jelátviteli kaszkád kezdődik ekkor, melynek része az intracelluláris $\mathrm{Ca}^{2+}$ koncentráció $\left(\left[\mathrm{Ca}^{2+}\right]_{\mathrm{i}}\right)$ megemelkedése, majd aktivációval összefüggő gének íródnak át, s végül a T-sejtek proliferációjával végződik. A limfociták Kv1.3 (feszültségfüggő $\mathrm{K}^{+}$) csatornájának felfedezésével egy időben derült ki, hogy ezek a csatornák központi szerepet játszanak a T-sejtek aktivációjának és proliferációjának szabályozásában [58]. Az IKCa1 ( $\mathrm{K}_{\mathrm{Ca}} 3.1$ a szisztematikus nómenklatúrában, $\mathrm{Ca}^{2+}$ aktivált $\mathrm{K}^{+}$) csatornákkal együtt a Kv1.3 csatornák döntően meghatározzák a T-sejtek membránpotenciálját, $\mathrm{s}$ ezen keresztül a sejtek aktivációjában kulcsszerepet játszó $\mathrm{Ca}^{2+}$ jelátvitelt $[59,60]$ (3. ábra). 


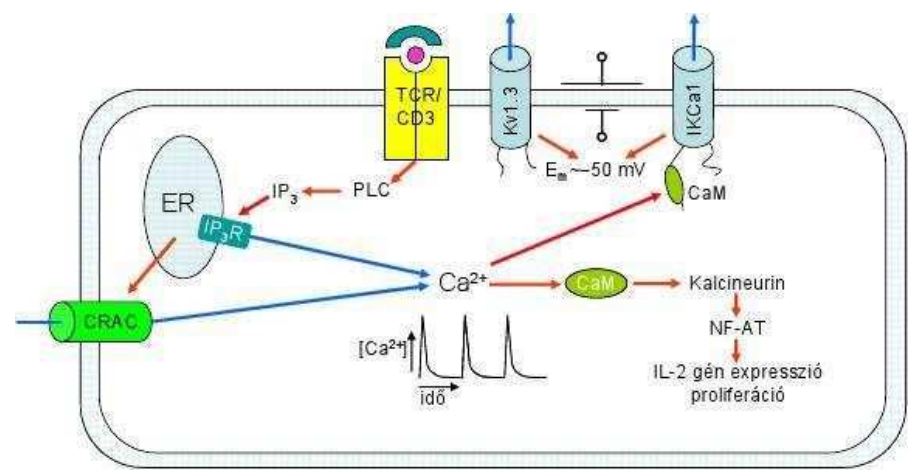

3. ábra: A Kv1.3 és IKCa1 csatornák szerepe a T-sejt receptor jelátvitelében

A Kv1.3 ioncsatorna négy egymáshoz nem kovalensen kapcsolódó alegységből áll (tetramer), melyek elrendeződése megközelítőleg szimmetrikus az együttesen létrehozott pórus körül. Az alegységek kb. 500 aminosavat tartalmaznak, minden egyes alegység 6 a membránt teljes egészében átérő helikális transzmembrán szegmensből áll (S1-S6), ezekhez és az őket összekötő intra- és extracelluláris hurkokhoz meghatározott funkciók tartoznak. Az S5 és S6 domének közötti extracelluláris hurkok, valamint az S6 szegmensek egyes részei együttesen alkotják a $\mathrm{K}^{+}$-csatorna pórusát, melyen keresztül a $\mathrm{K}^{+}$átjut a plazmamembránon. A csatorna ugyanezen régiója felelős a Kv1.3 csatornák számos peptid és kis-molekula gátlószerének kötéséért. A pórusrégió tartalmazza a $\mathrm{K}^{+}$ szelektivitást biztosító különösen konzervatív szelektivitási filter (GYGD) szekvenciát is. A membránpotenciál változásait a csatorna feszültségszenzora érzékeli, melyet a többszörösen pozitívan töltött S4 hélixek, ill. a nettó negatív töltést hordozó S3 hélixek közösen alkotnak. A feszültségszenzor membránpotenciál-függő elmozdulása a csatorna aktivációs kapujának megnyílásához vezet. Az aktivációs kaput magát a csatorna citoszolikus bejáratánál az S6 hélixek kereszteződése hozza létre.

Feszültségfüggő jellegéből adódóan a Kv1.3 csatorna fiziológiás funkciója a membránpotenciál és a $\mathrm{Ca}^{2+}$-jelátvitel szabályozása. Ez az ioncsatorna az immunrendszer és a központi idegrendszer jellemző feszültségfüggő ioncsatornája, de fellelhető az agyban, a tüdőben, hasnyálmirigy Langerhans szigetekben, a tímuszban, a lépben, a nyirokcsomóban, a fibroblasztokban, B- és T-limfocitákban, az elő(progenitor)-Bsejtekben, a mandulában, makrofágokban, mikrogliákban, oligodendrocitákban, oszteoklasztokban, vérlemezkékben és a herében is. 
Ma már számos kísérlet bizonyítja, hogy a T sejt aktivációhoz szükséges $\mathrm{Ca}^{2+}$ jel létrehozásában kulcsszerepet betöltő $\mathrm{K}^{+}$csatornák gátlásán keresztül a $\mathrm{T}$ sejtek proliferációja in vitro és in vivo is gátolható [57, 61].

Strukturálisan nagyon különböző nem peptid típusú vegyületekről bizonyosodott be, hogy gátolni képesek a limfociták Kv1.3 csatornáit. Ezen vegyületek (pl. 4aminopiridin, trietilamin, progeszteron, melatonin) kötődési mechanizmusukat és kötőhelyeiket illetően is igen sokszínúek. A gátlószer csoport közös neve ennek megfelelően „kis-molekula” inhibitor. A klasszikus nem peptid típusú csatornablokkolók mikro-, illetve millimoláris koncentrációban gátolták a Kv1.3 csatornákat.

A Kv1.3 csatornablokkolók másik csoportjába a peptid típusú toxinok tartoznak. Ezek már pico-, illetve nanomoláris koncentrációban is képesek hatni [62].

1.5.1.1. Skorpióméregből származó peptid toxinok mint szelektív Kv1.3 ioncsatorna gátló szerek

A skorpióméregből izolált $\mathrm{K}^{+}$csatorna toxinok 30-40 vagy 60-70 aminosavból állnak, mindegyikük rendelkezik egy $\alpha$-hélixszel és két $\beta$-redővel, melyeket 3 vagy 4 diszulfid híd stabilizál. Általános szerkezeti tulajdonságuk még a nagy affinitással kötődő toxinoknak az ún. ,esszenciális diád”, amely egy lizinből és egy tőle kilenc pozicióval Cterminális irányban elhelyezkedő aromás aminosavból áll. A toxinok hasonló 3 dimenziós szerkezete miatt a centrális lizin és az aromás aminosav $\alpha$ szénatomja egymástól néhány Angstrom távolságra van a molekula azon felszínén, mely az ioncsatornák extracelluláris pórusa felé tekint. Az aromás aminosav azonban nem tűnik szükségesnek a hatékony gátláshoz, de annál inkább a különböző csatornatípusok közötti szelektivitáshoz, mint pl. a Kv1.2 és Kv1.3 között. Ezzel szemben a diád lizin aminosavjának pozitív töltésü oldallánca, amely a blokkolás során a $\mathrm{K}^{+}$-csatorna szelektivitási filterébe nyúlik bele, nagyon fontos a nagy affinitású gátláshoz [62].

Mindemellett a toxin és a csatorna közötti hosszan tartó összekapcsolódás több ponton történő, különböző mechanizmusokon keresztüli kölcsönhatást igényel. Három alapvető mechanizmus járulhat hozzá a toxin-csatorna kölcsönhatáshoz. Az egyik ezek közül az ún. hosszú távú elektrosztatikus kölcsönhatás, ami a többszörösen pozitív töltésü toxin és a csatorna extracelluláris bejáratának negatív töltései között ébrednek. A másik, a 
pozitív töltésü diád lizin szempontjából lényeges kölcsönhatás a rövid távú, specifikus elektrosztatikus kölcsönhatás, és végül az oldalláncok közötti sztérikus kölcsönhatás. Nagyon valószínű az is, hogy egy toxinnak a különböző csatornák közötti szelektivitását az határozza meg, hogy mennyire különböznek a toxin-csatorna kontaktust létrehozó pontok és a következményes fizikokémiai kölcsönhatások. A nagy szelektivitás igen fontos abban az esetben, ha a toxint, vagy annak származékát a jövőben terápiás célokra szeretnék használni egy adott sejttípus speciális funkciójának módosításán keresztül. Ugyanakkor a majdani terápia mellékhatásának minimalizálása miatt is fontos a nagy szelektivitás, hogy más ioncsatorna típusra a toxin ne fejtsen ki hatást.

Doktori munkám olyan skorpiótoxinok, valamint ezen toxinok pontmutációkkal létrehozott szintetikus változatainak szintézisét célozza, amelyek növelt specificitású gátlószerei lehetnek a Kv1.3 ioncsatornáknak, tehát potenciálisan alkalmasak arra, hogy alkalmazásukkal a $\mathrm{T}_{\mathrm{EM}}$ sejtek szaporodását gátolva bizonyos autoimmun betegségek előrehaladását gátoljuk, ugyanakkor a szervezet kórokozókkal szembeni védekezőképességét megtartsuk.

1.5.2. C3a komplement eredetü peptidek az immunválasz szabályozásában

Számos idegen anyag vagy kórokozó a szervezetbe jutva képes azonnal aktiválni a testfolyadékokban jelen lévő komplementrendszert. Ennek eredményeként olyan biológiailag aktív molekulák keletkeznek, amelyek a különböző sejtekhez kötődve döntő módon befolyásolják azok müködését. A komplementrendszer a természetes immunrendszer egyik fontos eleme, de emellett nélkülözhetetlen az adaptív immunválasz minden fázisában, mivel részt vesz immunfolyamatok megindításában, szabályozásában, majd az effektor-fázisban is, vagyis a kórokozók, antigének és idegen anyagok eltakarítása során. Kulcsszerepe van ezekben a folyamatokban a C3-as komplementkomponensnek, amely "kettős kötődésre" képes. Ugyanis azzal a különleges tulajdonsággal rendelkezik, hogy az aktiváló felszínre - így egyes kórokozók és tumorsejtek membránjára, továbbá antigén-ellenanyag komplexekhez - kovalens módon kötődik, majd ezt követően különböző sejtek ún. C3-receptoraival képes kapcsolatba lépni [63]. E kötődés eredményeként számos nagyon fontos biológiai funkció valósul meg. Kimutatták, hogy ezek a komplement-közvetített kölcsönhatások az immunválasz 
kialakulására több pontban döntően hatnak: így befolyásolják az antigén-bemutatás folyamatát, a T- illetve a B-limfociták aktiválását, valamint az ellenanyag-termelést. Igazolták, hogy az antigén-bemutató sejthez kovalensen kötődő C3-fragmentumok jelentősen fokozzák az antigén-specifikus T-limfociták felszaporodását, így az adaptív immunválaszt. E folyamatban a C3 "kettős kötődése" alapvető szerepet játszik, ugyanis az antigén-bemutató sejthez kovalensen kötődő C3-fragmentumok az aktivált T-sejteken megjelenő C3-receptorokkal kölcsönhatásba lépve erősítik a két sejt közötti kölcsönhatást.

Az allergiás reakciók egyik legfontosabb effektorsejtje a hízósejt, amelyet az IgEtípusú ellenanyagot megkötő receptorok (FcعRI) allergének általi keresztkötése aktivál. E folyamat eredményeként a sejtek granulumainak tartalma a környezetbe ürül, és az allergiás reakciók jellegzetes tüneteit (tüsszögés, viszketés, bőr-pír, stb.) okozza. Ha azonban a komplement-eredetü peptid a sejtekhez kötődik, ez a folyamat gátolt, és nem szabadulnak ki a sejtből a túlérzékenységi reakciót előidéző anyagok (pl. a hisztamin) [64].

Kutatócsoportunk az ELTE Immunológiai Tanszékével együttműködésben már korábban kimutatta, hogy a komplement rendszerből származó C3a peptid gátolja a mukóza típusú hízósejtek IgE közvetített aktivációját, degranulációját (4. ábra). A gátló hatás létrejöttében az 56-64-es szekvencia szerepe döntő $[65,66]$.

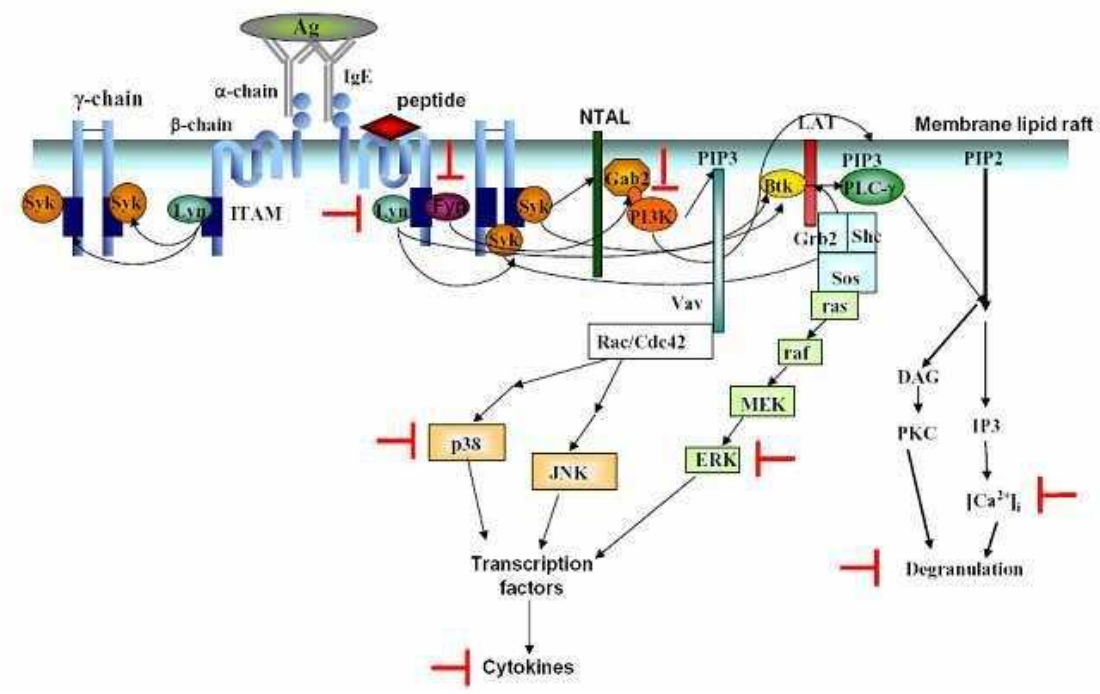

4. ábra: A C3a9 szekvencia általi bizonyított gátlási pontok $(\mathrm{T})$

Doktori munkám során a C3a-eredetü C3a9 peptid dimer származékainak 
szintézise volt a cél, annak a feltételezésnek az igazolására miszerint az allergiás reakciók gátlása a szekvencia között kialakuló diszulfid hidakkal képzett dimereknek köszönhető.

1.5.3. A Gab1 adapter fehérje szerepe a B sejtek jelátviteli szabályozásában

$\mathrm{Az}$ immunsejtek antigénfelismerő receptoraikon keresztül ismerik fel a kórokozókat, a szervezet számára idegen anyagot, ami elindítja a sejtaktiválódáshoz vezető jelátviteli folyamatot. A receptorok ligandum felismerését a sejten belül számos enzim, köztük kinázok, foszfatázok, foszfolipázok aktiválódása követi. A jelátvitel során fehérjehálózatok lépnek kölcsönhatásba, enzimek aktiválódása és inaktiválódása, sejten belüli- és membránfehérjék átrendeződése megy végbe, és az egymásra épülö, kaszkádszerüen bekövetkezett események végén a transzkripciós faktorok aktiválódása következtében génátírási folyamatok kezdődnek el a sejtmagban.

Az adapter fehérjék rendkívül fontos szerepet töltenek be a különböző stimulusok hatására aktiválódó jelpályák szabályozásában, illetve a jel amplifikációjában. Olyan enzimatikusan inaktív fehérjék, amelyek a felszínükön található tirozinon foszforilált peptidszekvenciái, illetve prolinban gazdag régiói segítségével különböző - SH2, PTB, SH3 - domén tartalmú enzimeket, illetve további adapter fehérjéket gyüjtenek egy multimolekuláris jelátviteli komplexbe [67]. Tehát a jelátviteli hálózatban szereplő különböző enzimek és azok szubsztrátjainak térbeli lokalizációját szabályozva az egyes jelpályák integrálásában van szerepük. Az ún. scaffolding adapter fehérjék sajátsága, hogy rendelkeznek egy sejtmembránhoz kapcsoló PH doménnel, illetve valamilyen zsírsav-oldallánccal, ami által képesek a jelátviteli fehérjéket a membrán asszociált receptorok közelébe toborozni.

A scaffolding adapter fehérjék közé soroljuk a Gab1 (Grb2 associated binder1) fehérjét [68]. A ligand általi receptor keresztkötést követően a Gab1 számos tirozinján foszforilálódik. A foszfotirozin tartalmú motívumokhoz SH2 doménnel rendelkező fehérjék asszociálódnak, mint például az SHP2 tirozin foszfatáz [69] és a foszfatidilinozitol-3-kináz (PI3-K) [70]. A Gab1/SHP2 kapcsolat lényeges szerepet játszik a sejtnövekedés szabályozásában, míg a PI3-K-nak a túlélési és proliferációs szignálokban van nélkülözhetetlen szerepe [71, 72]. A Gab1/SHP2 és a Gab1/PI3-K fehérje kölcsönhatások (5. ábra) ebböl kifolyólag a tumor terápiás kutatások kiemelt célpontjaivá válhatnak. 


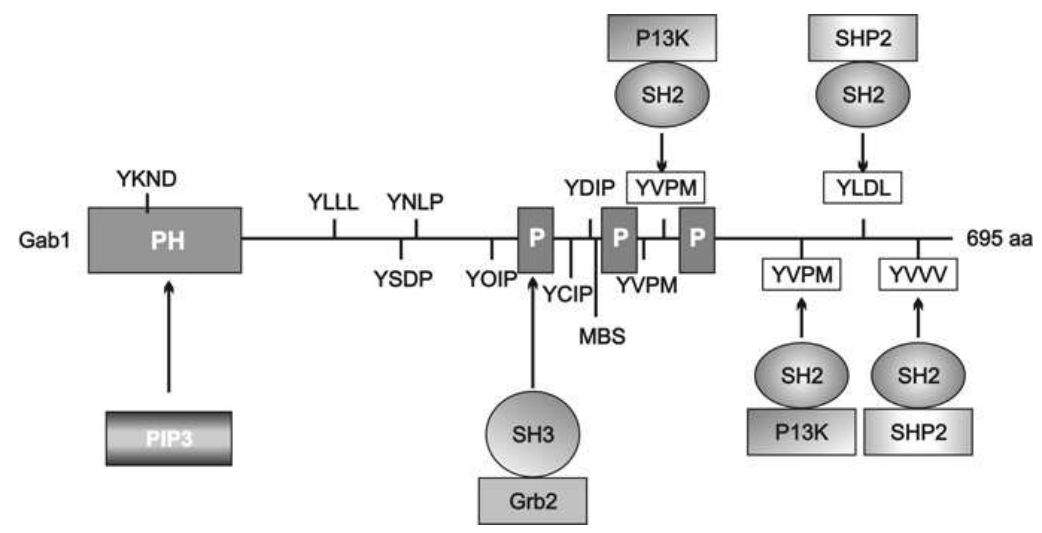

5. ábra: A Gab1/2 fehérjék molekuláris kölcsönhatásai

Doktori munkám során olyan, az SH2 doménekkel interakcióba lépő, szintetikus foszfopeptidek szintézise volt a cél, amelyek gátolhatják a fehérje-fehérje kapcsolatok kialakulását, befolyásolva ezáltal a jelátviteli folyamatok kimenetelét.

\subsection{Mozgékony fehérje térszerkezeti elemek konformációs egyensúlyának vizsgálata $\beta$-modellpeptidek és minifehérjék segítségével}

A fehérjék feltekeredése, valamint az azzal egyensúlyban lévő kitekeredési lépések kritikus pontjai a makromolekulák szabályozásának és izgalmas példái a biológiai aktivitás kontrollálásának. Az egyre jobban megismert konformációs vagy „aggregációs” betegségek közös jellemvonása a hibásan vagy részlegesen feltekeredett fehérjék aggregációja. Jó példa erre az Alzheimer- és a Parkinson-kór, melyben a kitekeredett fehérjék - kikerülve a sejt védő mechanizmusa alól - oldhatatlan plakkokat képeznek a sejtben illetve sejtközi térben. Az ún. amiloid típusú betegségekben alapvetően hasonló szerkezetűek az aggregátumokat felépítő amiloid szálak; törzsszerkezetük $\beta$-redőzött rétegekből formálódik, amelynek szálai gyakran merőlegesek az amiloid szál fötengelyére. Normális körülmények között a dajkafehérjék és a „molekuláris chaperonok” más szabályozó rendszerekkel együtt rendkívül hatékonyak a potenciálisan toxikus gócok és prefibrilláris aggregátumok semlegesítésében. A védekező mechanizmus sérülése, a chaperonok és más sejtszervecskék helytelen viselkedése hozzájárulhat a fehérjék kitekeredéséhez és az aggregációs betegségek kialakulásához.

Ahhoz, hogy hatékonyan küzdhessünk ezen betegségek ellen, fontos, hogy megértsük a fehérje feltekeredés atomi szintü mechanizmusát, s ehhez elengedhetetlen a 
peptidek, illetve fehérjék konformációs egyensúlyának kvantitatív vizsgálata. Ennek eszközei az ún. minifehérjék vagy modellpeptidek.

E munka keretei közt háromszálú $\beta$-redőzött réteg térszerkezetű minifehérjék (Betanova), $\beta$-hajtükanyar térszerkezetü polipeptidek (SETE-peptidek), valamint a Tc5b minifehérje néhány foszfo- és glikoanalógjának konformációs egyensúlyát vizsgáltuk. 


\section{Célkitüzések}

Doktori munkám során az alábbi célokat tüztem ki:

- A stresszválasz szabályozásában hatékonyan résztvevő urokortin 3 (Ucn 3) neuropeptid, valamint ezen peptid célzott rövidítésével kapott fragmenseinek előállítása a molekula antidepresszáns és szorongáscsökkentő hatásáért felelős aktív centrumának lokalizálása céljából és ezen fragmensek tesztelése hatástani vizsgálatokban.

- Az Ucn 3 hatásáért felelős aktív centrum alapján olyan analógok tervezése és szintézise, amelyek megőrzik, esetlegesen javítják a hosszabb szekvencia antidepresszáns és szorongáscsökkentő hatását, valamint farmakokinetikai szempontból elönyösebb tulajdonságokkal rendelkeznek, vagyis potenciális farmakonokként szerepelhetnek depresszió és szorongás kezelésében.

- Az orexin A neuropeptid szintézisének optimalizálása, valamint vizsgálata a vízanyagcserére és a vazopresszin kiválasztásra patkányban.

- A természetes és adaptív immunrendszer jelátviteli folyamataiban szelektíven ható szintetikus peptidek előállítása, amelyek különböző immunológiai betegségekre ható gyógyszerkészítmények fejlesztésének alapját képezhetik:

○ A Mexikóban honos Anuroctonus phaiodactylus-ból izolált anuroctoxin, illetve a Brazíliában honos Tityus cambridgei-ből izolált Tc32 skorpiótoxinok natív szekvenciáinak szintézise, amelyek potenciális Kv1.3 ioncsatorna gátló szerek.

○ A szintetizált natív szekvenciák alapján pontmutációkkal olyan Kv1.3 ioncsatorna gátló szerek szintézise és vizsgálata, amelyek nagyobb szelektivitásúak és hatékony immunszuppresszív hatású gyógyszerkészítmények alapjául szolgálhatnak.

○A C3a eredetű C3a9 szimmetrikus dimer szintézise annak a feltételezésnek az igazolására, hogy az allergiás reakciók kialakulásának gátlásáért a C3a9 peptid intermolekuláris diszulfid hidakkal stabilizált dimer formája a felelős.

○Gab1 eredetü foszfopeptidek, illetve ezen peptidek módosított szekvenciáinak előállítása, biotinilálása, valamint sejtpermeábilis hordozó peptidhez való kapcsolása, majd a B-sejtek jelátviteli folyamataiban betöltött szerepének vizsgálata. 
- $\beta$-modellpeptidek (SETE-peptidek) és minifehérjék (Betanova, Tc5b) szintézise és konformációs egyensúlyi vizsgálata. 


\section{Eredmények és megvitatásuk}

\subsection{Stresszválasz szabályozás a CRF családba tartozó Ucn 3 eredetü szintetikus peptidekkel}

Az urokortin 3 egy 38 aminosavból álló peptid, amelynek szekvenciáját és az első 5, 6, 7 vagy 8 aminosav elhagyásával kapott hosszú, maximum 30 aminosavat tartalmazó fragmenseit, valamint mindezek aminosav helyettesítéseket tartalmazó származékait már korábban leírták [73]. Mind a természetes, mind az aminosav helyettesítéseket tartalmazó származékokat és fragmentumokat az alábbi kórélettani állapotok kezelésére alkalmazták: láz, étvágyproblémák, vaszkuláris problémák, gasztrointesztinális rendellenességek, szívbetegségek, stressz, szorongás, alacsony glukagon szekréció, migrénes fejfájás és diabetes mellitus. Korábbi kutatómunkánk során azt találtuk, hogy az urokortin 3 alkalmas lehet arra, hogy megkíséreljünk belöle antidepresszáns és szorongáscsökkentő hatású anyagokat fejleszteni $[74,75]$.

3.1.1. Antidepresszáns és szorongáscsökkentő hatású Ucn 3 és fragmenseinek előállítása és vizsgálata

Az Ucn 3 alapú gyógyszerfejlesztés első lépéseként a neuropeptid antidepresszáns és anxiolitikus hatásáért felelős aktív centrumának lokalizálása volt az elsődleges cél. Az általam előállított Ucn 3 és rövidebb fragmenseinek szekvenciáját a 3. táblázat mutatja be.

3. táblázat: Az Ucn 3 és rövidebb fragmenseinek szekvenciái

\begin{tabular}{|l|c|c|}
\hline \multicolumn{1}{|c|}{ Kód } & $\begin{array}{c}\text { Aminosavak } \\
\text { száma }\end{array}$ & Szekvencia \\
\hline Ucn 3 & 38 & FTLSLDVPTNIMNLLFNIAKAKNLRAQAAANAHLMAQI-NH \\
\hline Ucn 3 (18-38) & 21 & IAKAKNLRAQAAANAHLMAQI-NH \\
\hline Ucn 3 (19-27) & 11 & AKAKNLRAQ-NH $_{2}$ \\
\hline Ucn 3 (28-38) & 9 & AAANAHLMAQI-NH $_{2}$ \\
\hline Ucn 3 (34-38) & 5 & LMAQI-NH $_{2}$ \\
\hline Ucn 3 (36-38) & 3 & AQI-NH $_{2}$ \\
\hline Ucn 3 (34-36) & 3 & LMA-NH $_{2}$ \\
\hline
\end{tabular}


Az Ucn 3, valamint ezen szekvencia fragmenseinek előállítását manuális szilárd fázisú peptidszintézis módszerével valósítottam meg. A peptideket MBHA hordozón építettem fel Boc/Bzl stratégia alkalmazásával. A szintézisben használt Boc-védett aminosav származékok hidrogén-fluoriddal hasítható oldallánc védőcsoporttal rendelkeztek. A Boc/Bzl-stratégiánál az $N$-terminális Boc védőcsoportot trifluorecetsav/ diklórmetán elegyével hasítottam le, ezt követően mostam és semlegesítettem a gyantát kapcsolás elött. A kapcsoláshoz 3-3 ekv. mennyiségben használtam a védett aminosav származékokat, DCC-t és HOBt-t. A kapcsolást követő mosási lépések (DCM, MeOH) után ninhidrin teszttel ellenőriztem a kapcsolás sikerességét. A kész peptideket a gyantáról folyékony hidrogén-fluoriddal hasítottam le, gyökfogóként anizolt, dimetilszulfidot és $p$-krezolt használtam. A kapott nyers peptideket szemipreparatív RP-HPLCvel tisztítottam meg, majd a tiszta termékeket analitikailag jellemeztem retenciós idejük és molekulatömegük alapján (4. táblázat).

4. táblázat: Az Ucn 3 és rövidebb fragmenseinek analitikai paraméterei

\begin{tabular}{|l|c|c|c|c|}
\hline \multicolumn{1}{|c|}{ Kód } & $\begin{array}{c}\text { Analitikai HPLC } \\
\text { gradiens }\end{array}$ & $\begin{array}{c}\mathbf{t}_{\mathbf{R}}{ }^{*} \\
(\text { perc })\end{array}$ & $\mathbf{M}_{\text {számított }}$ & $\begin{array}{c}\mathbf{M}_{\text {mérr }^{\dagger}} \\
\left(\left[\mathbf{M}+\mathbf{H}^{\dagger}\right]^{+}\right.\end{array}$ \\
\hline Ucn 3 & $43-58(\% \mathrm{~B}) ; 15$ perc & 9.34 & 4173.0 & 4174 \\
\hline Ucn 3 (18-38) & $43-58(\% \mathrm{~B}) ; 15$ perc & 8.00 & 2203.6 & 2204 \\
\hline Ucn 3 (19-27) & $40-60(\% \mathrm{~B}) ; 20$ perc & 10.55 & 998.2 & 999 \\
\hline Ucn 3 (28-38) & $10-30(\% \mathrm{~B}) ; 20$ perc & 6.88 & 1109.3 & 1110 \\
\hline Ucn 3 (34-38) & $28-42(\% \mathrm{~B}) ; 15$ perc & 7.65 & 573.7 & 574 \\
\hline Ucn 3 (36-38) & $10-25(\% \mathrm{~B}) ; 15$ perc & 7.99 & 332.4 & 333 \\
\hline Ucn 3 (34-36) & $10-25(\% \mathrm{~B}) ; 15$ perc & 9.21 & 329.4 & 330 \\
\hline
\end{tabular}

*: Retenciós idő meghatározása Agilent 1100 HPLC rendszeren (oszlop: Phenomenex Luna $5 \mu \mathrm{m}$ C18(2) 100Å; 250x4.60 mm; áramlási sebesség: $1.0 \mathrm{ml} /$ perc; eluensek: A-Eluens: 0.1\% TFA/víz; B-Eluens: $80 \%$ acetonitril $/ 20 \%$ víz/ $0.1 \%$ TFA)

${ }^{\dagger}$ : MS $\left(\mathrm{ESI}^{+}\right): m / z$; monoizotópos molekulatömeg meghatározása Finnigan TSQ 7000 ESI-MS-en.

A hatástani vizsgálatokat a szegedi ÁOK Kórélettani Intézetében végezték. A kísérletekhez Wistar hím patkányokat vagy CFPL hím egereket használtak. A kísérleti állatokba altatásban az oldalsó agykamrába kanült építettek be és legalább öt nap elteltével kezdték a vizsgálatokat. A vegyületeket steril desztillált vízben oldották és $2 \mu 1$ dózistérfogatban adagolták. A legmagasabb koncentráció $2 \mu \mathrm{g} / \mu 1$ volt. Az anxiolitikus hatás vizsgálata keresztlabirintus (EPM, elevated-plus-maze test) teszttel történt. A teszt lényege, hogy mérhető az állat tartózkodási ideje egy jól definiált labirintus nyitott 
karjában, mely számára félelmet provokál. Az eredményeket a nyitott kar/(nyitott + zárt kar) százalékában fejezzük ki. Az antidepresszáns hatás vizsgálatára az erőltetett úszás teszt (FST, forced swimming test) módosított változatát alkalmazták. A tesztben mérhető az állatok mászási ideje, az úszási idő és a mozdulatlansági idő egy $25^{\circ} \mathrm{C}$ hőmérsékletű vízzel teli üveghengerben.

Az eredmények statisztikai értékelése variancia analízissel történt és az ezt követő páronkénti összehasonlításokhoz Tukey tesztet alkalmaztak.

Az Ucn 3 és rövidebb fragmensei hatástani vizsgálatainak eredményeit a 6-9. ábrák mutatják.

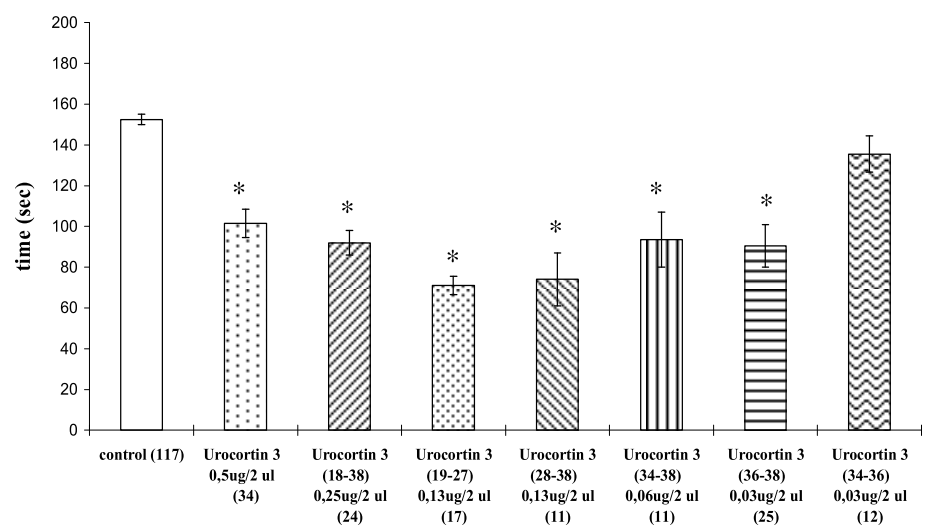

6. ábra: Az Ucn 3 és fragmenseinek hatása az immobilitásra a módosított FST-ben $(\mathrm{P}<0.05$ vs. Control, $\mathrm{P}$ : valószínűség, N: tesztelt állatok száma)

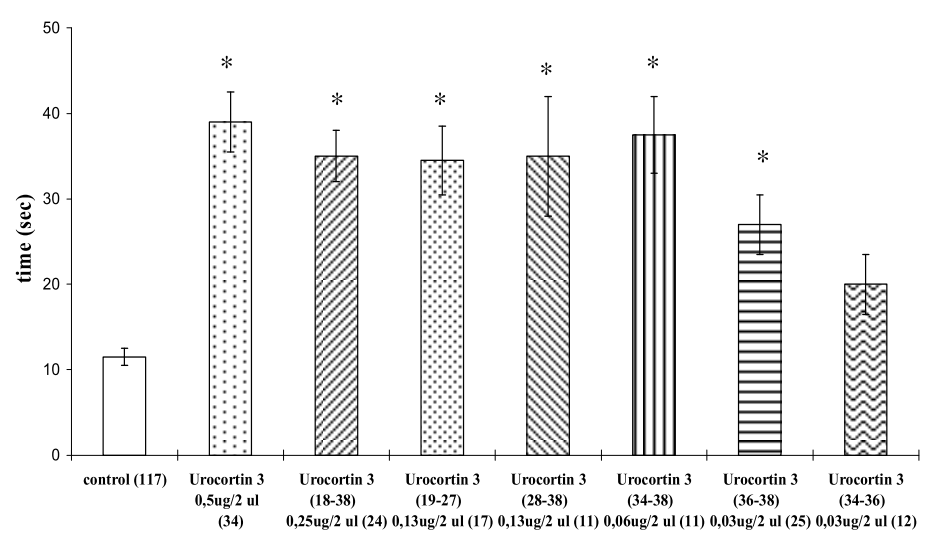

7. ábra: Az Ucn 3 és fragmenseinek hatása az úszási időre a módosított FST-ben ( $\mathrm{P}<0.05$ vs. Control, $\mathrm{P}$ : valószínüség, $\mathrm{N}$ : tesztelt állatok száma) 


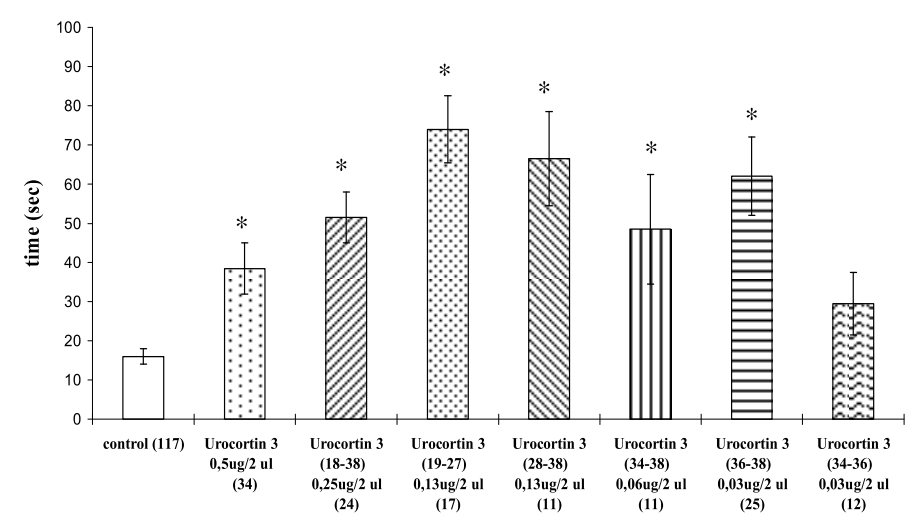

8. ábra: Az Ucn 3 és fragmenseinek hatása a mászásra a módosított FST-ben

$(\mathrm{P}<0.05$ vs. Control, $\mathrm{P}$ : valószínüség, $\mathrm{N}$ : tesztelt állatok száma)

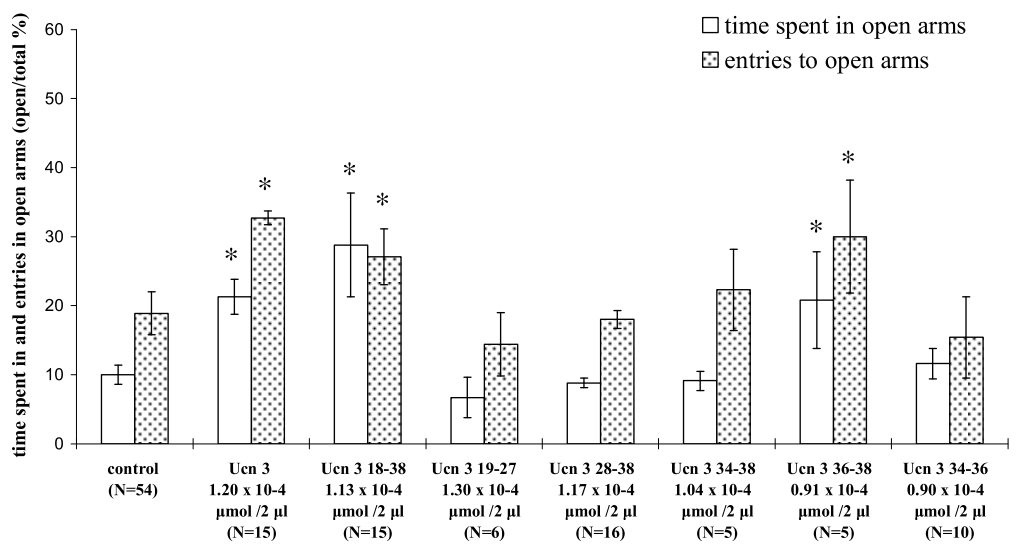

9. ábra: Az Ucn 3 és fragmenseinek hatása az EPM tesztben

$(\mathrm{P}<0.05$ vs. Control, $\mathrm{P}$ : valószínüség, $\mathrm{N}$ : tesztelt állatok száma)

Azt találtuk, hogy az urokortin $3 C$-terminálisán elhelyezkedő Ala-Gln-Ile- $\mathrm{NH}_{2}$ (peptidkód: AQI) tripeptid megőrzi a hosszabb Ucn 3 antidepresszáns és szorongáscsökkentő hatását, ez a tripeptid a felelős a molekula ezen hatásáért. A továbbiakban ezt a tripeptidet használtam módosított származékok tervezésének alapjául.

3.1.2. Antidepresszáns és szorongáscsökkentő hatású Ucn 3 analógok tervezése, elöállítása és vizsgálata

A tervezett és előállított módosítások (10. ábra) során több mint 20, nagyobb részben peptidomimetikum származékát készítettem el az Ucn 3 (36-38) fragmensnek és ezek többségének biológiai vizsgálatára is sor került. 

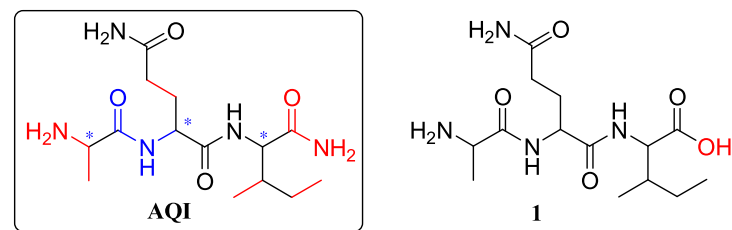<smiles>CC(C)CC(NC(=O)C(CCC(N)=O)NC(=O)C(C)N)C(N)=O</smiles><smiles>CC(N)C(=O)NC(CC(N)=O)C(=O)NC(C(N)=O)C(C)C</smiles><smiles>CCC(C)C(NC(=O)C(CCC(N)=O)NC(=O)CN)C(N)=O</smiles><smiles>CCC(C)C(NC(=O)C(CCC(N)=O)NC(C)=O)C(N)=O</smiles><smiles>CCC(C)C(NC(=O)C(CC(N)=O)NC(=O)C(C)N)C(N)=O</smiles><smiles>CCC(C)C(NC(=O)C(CCCNC(N)=O)NC(=O)C(C)N)C(N)=O</smiles><smiles>CCC(C)C(NC(=O)C(CC(C)CN)NC(=O)C(C)N)C(N)=O</smiles><smiles>CCC(C)C(NC(=O)C(CCC(N)=O)NC(=O)C(C)N)C(N)=O</smiles><smiles>CCC(C)C(N)C(=O)NC(CCC(N)=O)C(=O)NC(C)C(N)=O</smiles><smiles>CC(C)CNC(=O)C(CCC(N)=O)NC(=[V])OC(C)C</smiles><smiles>CC(=O)NC(CCC(N)=O)C(=O)NCC(C)C</smiles><smiles>CC(=O)NC(CCC(N)=O)C(=O)NCC(C)C</smiles>

* : fennáll az aminosa konformációs csere lehetõsége

12

13

*: $D$-aminosav<smiles>[R3]C(=O)NC(CCC(N)=O)C(=O)NC(C(N)=O)C(C)CC</smiles>

14<smiles>[R5]CCNCC(C)C</smiles>

$14 a$

$14 b$

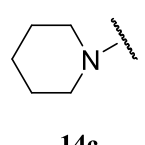

$14 c$

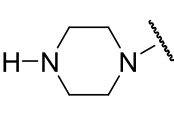

14d

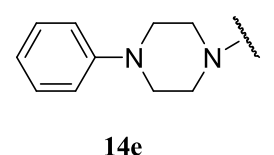

$14 \mathrm{e}$<smiles>CCCCN(CCC(N)=O)C(=O)NC(C(N)=O)C(C)CC</smiles>

$15 \mathbf{a}$<smiles>CCC(C)C(NC(=O)N(N)CCC(N)=O)C(N)=O</smiles>

$15 b$<smiles>CCC(C)C(NC(=O)N(CCC(N)=O)NC(=O)C(C)N)C(N)=O</smiles>

$15 c$<smiles>CCC(C)C(=O)NN(CCC(N)=O)C(=O)OCC(C)C</smiles>

16

10. ábra: Az Ucn 3 (36-38), AQI tripeptid analógok szerkezete

A 2-10 analógok előállítása MBHA hordozón történt az Ucn 3 és fragmenseinél már leírt módon. A $D$-aminosavak beépítésénél a hagyományos szilárd fázisú peptidszintézis módszerei alkalmazhatóak, beépítésük nem igényli a reakciókörülmények megváltoztatását. Az 1 analóg szintézise annyiban tér el az elöbbiektől, hogy szintézise Merrifield polimeren történt a $C$-terminálisan szabad karboxil kialalakítása miatt. Az első aminosav polimerhez való kapcsolása ebben az esetben kálium só formájában lehetséges. 
A peptidláncok felépítéséhez végig 3-3 ekv. mennyiségü Boc-aminosav származékot, DCC-t és HOBt-t használtam. A peptidek gyantáról való hasítása folyékony hidrogénfluoriddal történt mindegyik esetben, gyökfogóként anizolt, dimetil-szulfidot és p-krezolt használtam. A nyers peptidek tisztítása szemipreparatív RP-HPLC-vel történt és a tiszta származékokat minden esetben analitikailag jellemeztem retenciós idejük és molekulatömegük alapján (5. táblázat).

Az 5 analóg szintézise annyiban tér el az előzőekben leírtaktól, hogy a peptid $N$ terminális aminosavát acetileztem. Az acetilezési reakcióhoz a szabad amino csoportot ecetsavanhidrid diklórmetán oldatával kezeltem. A reakció sikerességét ninhidrin próbával követtem.

5. táblázat: Az 1-10 analógok analitikai jellemzői

\begin{tabular}{|c|c|c|c|c|}
\hline Kód & $\begin{array}{c}\text { Analitikai HPLC } \\
\text { gradiens }\end{array}$ & $\mathbf{t}_{\mathbf{R}}{ }^{*}($ perc $)$ & $\mathbf{M}_{\text {számított }}$ & $\begin{array}{c}\mathbf{M}_{\text {mért }^{\dagger}} \\
\left([\mathbf{M}+\mathbf{H}]^{+}\right)\end{array}$ \\
\hline 1 & $13-28(\% \mathrm{~B}) ; 15$ perc & 5.85 & 330.3 & 331 \\
\hline 2 & $7-22(\% B) ; 15$ perc & 7.52 & 329.4 & 330 \\
\hline 3 & $0-15(\% \mathrm{~B}) ; 15$ perc & 7.52 & 315.3 & 316 \\
\hline 4 & $5-20(\% \mathrm{~B}) ; 15$ perc & 6.81 & 315.3 & 316 \\
\hline 5 & $7-22(\% B) ; 15$ perc & 7.95 & 300.3 & 301 \\
\hline 6 & $6-21(\% \mathrm{~B}) ; 15$ perc & 5.84 & 315.5 & 316 \\
\hline 7 & $9-24(\% \mathrm{~B}) ; 15$ perc & 7.95 & 358.4 & 359 \\
\hline 8 & $8-23(\% \mathrm{~B}) ; 15$ perc & 7.65 & 329.1 & 330 \\
\hline 9 & $10-25(\% \mathrm{~B}) ; 15$ perc & 6.65 & 329.4 & 330 \\
\hline 10 & $8-23(\% B) ; 15$ perc & 6.41 & 329.4 & 330 \\
\hline
\end{tabular}

*: Retenciós idő meghatározása Agilent 1100 HPLC rendszeren (oszlop: Phenomenex Jupiter 10 $\mu \mathrm{m}$ C18 300Å; 250x4.60 mm; áramlási sebesség: $1.2 \mathrm{ml} /$ perc; eluensek: A-Eluens: $0.1 \%$ TFA/víz; B-Eluens: $80 \%$ acetonitril $/ 20 \%$ víz/ $0.1 \%$ TFA)

${ }^{\dagger}$ : MS $\left(\mathrm{ESI}^{+}\right): \mathrm{m} / z$; monoizotópos molekulatömeg meghatározása Finnigan TSQ 7000 ESI-MS-en.

A 11-13 analógok szintézise oldatfázisban történt a megfelelő Boc-védett $L$ - vagy $D$-glutaminsavból kiindulva. A $C$-terminális izobutil amin kapcsolásához a vegyes anhidrides módszert választottam, 1.1 ekv. klórhangyasav-izobutil észtert és DIEA-t használva. A 12-13 analógok esetében az $N$-terminális Boc-védőcsoport TFA-val történő eltávolítása után, acetileztem a szabad aminocsoportot ecetsavanhidriddel. A kész 11-13 analógokat szemipreparatív HPLC-vel tisztítottam és analitikailag jellemeztem retenciós idejük és molekulatömegük alapján (6. táblázat). 
Az urea-peptidek szintézisére azért került sor, mert ezek a származékok mint peptidomimetikumok, lényegesen kedvezőbb farmakokinetikai tulajdonságokkal rendelkeznek a peptidekhez képest, mint például a felszívódás, toxicitás, merevebb a szerkezetük és nagyobb a metabolikus stabilitásuk.

Az aszimmetrikus karbamidok szintézise a megfelelő izocianát és primer amin reakciójával lehetséges [76, 77]. Az aminosav észterek vagy peptid észterek hidroklorid sójából nyert izociánátok szintézise a megfelelő amino komponens toluolban történő refluxáltatásával lehetséges melybe foszgén gázt buborékoltatunk több órán keresztül vagy használhatjuk a Nowick és társai által tökéletesített módszert [78], mely egy kétfázisú rendszert javasol, egyrészt a toluolban oldott foszgént, másrészt a nátrium karbonát vizes oldatát vagy piridint fölöslegben. Újabban a „zöld kémiá”-ra való tekintettel a foszgént a kevésbé szennyező trifoszgén [bis(triklórmetil)karbonát] váltotta fel. Egy másik lehetséges szintézisút az aktív karbamátokon keresztül valósulhat meg, amelyek egy következő lépésben a szabad aminnal reagálnak ureát eredményezve. A leggyakrabban használt karbamátok a 2,4,6-triklór-fenil karbamát és a $p$-nitro-fenil karbamát. A legújabb szintézisstratégiák leginkább a Curtius és a Hoffmann átrendeződésen alapulnak $[79,80]$.

$\mathrm{Az}$ általam választott módszer lényege, hogy a gyantára kötött Fmoc-védett aminosav trimetilklórszilánnal $\left(\mathrm{MeSiCl}_{3}\right)$ egy lépésben alakítható át izocianáttá, majd ezt a megfelelő aminnal reagáltatva urea-peptideket kapunk [81, 82]. A hidantoin képződés, mint lehetséges mellékreakció, a megfelelő oldószer, valamint szekunder amin használatával teljes mértékben elkerülhető. A szintézis módszert a 11. ábra mutatja be.
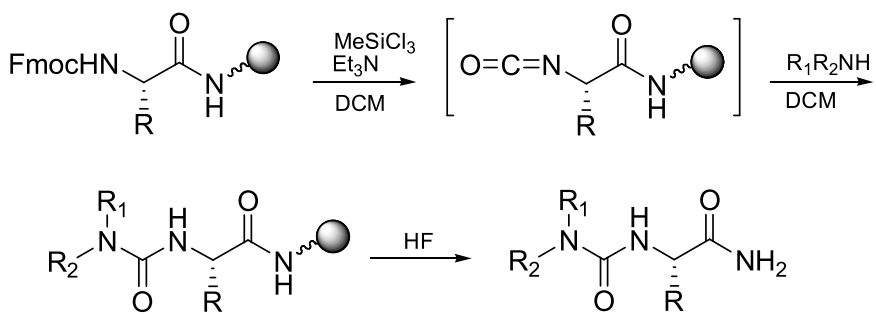


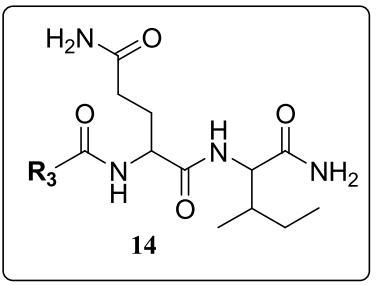

$\mathbf{R}_{3}: \sim \mathrm{N}_{-\xi}^{\mathrm{H}}$
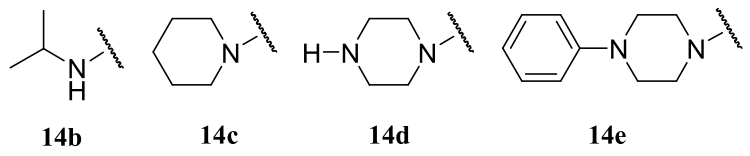

11. ábra: Az urea-peptidek általános szintézismódszere és az előállított Ucn 3 (36-38) urea-analógok szerkezete

A 14a-e analógok előállítása manuális szilárd fázisú peptidszintézis módszerével történt MBHA hordozón egy kombinált Fmoc/Boc stratégiával. A peptidláncot Bockémiával építettem fel a glutaminig, amely Fmoc-védett $N$-terminálisát egy lépésben alakítottam izocianáttá $10 \mathrm{ekv}$. $\mathrm{MeSiCl}_{3}$ és $20 \mathrm{ekv}$. trietilamin jelenlétében. A keletkező izocianát-intermedier nem stabil, ezért in situ reagáltattam a megfelelö bázis 10 (v/v\%)os oldatával. Az általam tervezett Ucn 3 (36-38) urea-analógok (14a-e) esetén bázisként propilamint, izopropilamint, piperidint, piperazint és 1-fenil-piperazint használtam. A kész urea-peptideket a gyantáról folyékony hidrogén-fluoriddal hasítottam le, szemipreparatív RP-HPLC-vel tisztítottam és analitikailag jellemeztem retenciós idejük és molekulatömegük alapján (6. táblázat).

6. táblázat: Az Ucn 3 (36-38) 11-14e analógjainak analitikai jellemzői

\begin{tabular}{|c|c|c|c|c|}
\hline Kód & $\begin{array}{c}\text { Analitikai HPLC } \\
\text { gradiens }\end{array}$ & $\mathbf{t}_{\mathbf{R}}{ }^{*}$ (perc) & $\mathbf{M}_{\text {számított }}$ & $\begin{array}{c}\mathbf{M}_{\text {mért }^{\dagger}} \\
\left(\left[\mathbf{M}^{\dagger}+\mathbf{H}^{+}\right)\right.\end{array}$ \\
\hline $\mathbf{1 1}$ & $30-45(\% B) ; 15$ perc & 6.97 & 301.4 & 302 \\
\hline $\mathbf{1 2}$ & $10-25(\% B) ; 15$ perc & 6.37 & 243.3 & 244 \\
\hline $\mathbf{1 3}$ & $16-31(\% B) ; 15$ perc & 6.61 & 243.3 & 244 \\
\hline $\mathbf{1 4 a}$ & $26-41(\% B) ; 15$ perc & 9.01 & 343.4 & 344 \\
\hline $\mathbf{1 4 b}$ & $23-38(\% B) ; 15$ perc & 7.74 & 343.4 & 344 \\
\hline $\mathbf{1 4 c}$ & $23-38(\% B) ; 15$ perc & 8.04 & 369.4 & 370 \\
\hline $\mathbf{1 4 d}$ & $20-35(\% B) ; 15$ perc & 8.92 & 370.4 & 371 \\
\hline $\mathbf{1 4 e}$ & $20-35(\% B) ; 15$ perc & 7.79 & 446.5 & 447 \\
\hline
\end{tabular}

*: Retenciós idő meghatározása Agilent 1100 HPLC rendszeren (oszlop: Phenomenex Luna $5 \mu \mathrm{m}$ C18(2) 100Å; 250x4.60 mm; áramlási sebesség: $1.0 \mathrm{ml} /$ perc; eluensek: A-Eluens: 0.1\% TFA/víz; B-Eluens: $80 \%$ acetonitri1/20\% víz/0.1\% TFA)

${ }^{\dagger}$ : MS (ESI ${ }^{+}$): $m / z$; monoizotópos molekulatömeg meghatározása Finnigan TSQ 7000 ESI-MS-en.

$\mathrm{Az}$ urea típusú peptidomimetikumokon kívül az azapeptidek rendelkeznek farmakokinetikai szempontból előnyös tulajdonságokkal, például a peptidekhez képest sokkal inkább ellenállnak a hidrolízisnek (mind a kémiai, mind az enzimatikus hidrolízisnek), ezért aktivitás, hatás szempontjából a biológiailag aktív peptideknél értékesebb analógokra lelhetünk bennük. Az azapeptidek sajátsága, hogy a peptidgerinc 
módosul, hiszen az $\alpha$-szénatom kicserélődik egy N-atomra. Építőkövei az azaaminosavak, szintézisük és beépítésük a peptidláncba a hidrazin- és a peptidkémia kombinációját feltételezi [83, 84].

Általában egy hidrazidot reagáltatnak egy aktivált „karbonil donorral”, a peptidlánc hosszabbításához a hagyományos peptidkémiai kapcsolószereket használják. A módszert a beépítendő azaaminosav milyensége és a peptidláncban elfoglalt helye határozza meg [83]. Az azapeptidek szintézisének lehetőségeit a 12. ábra foglalja össze.

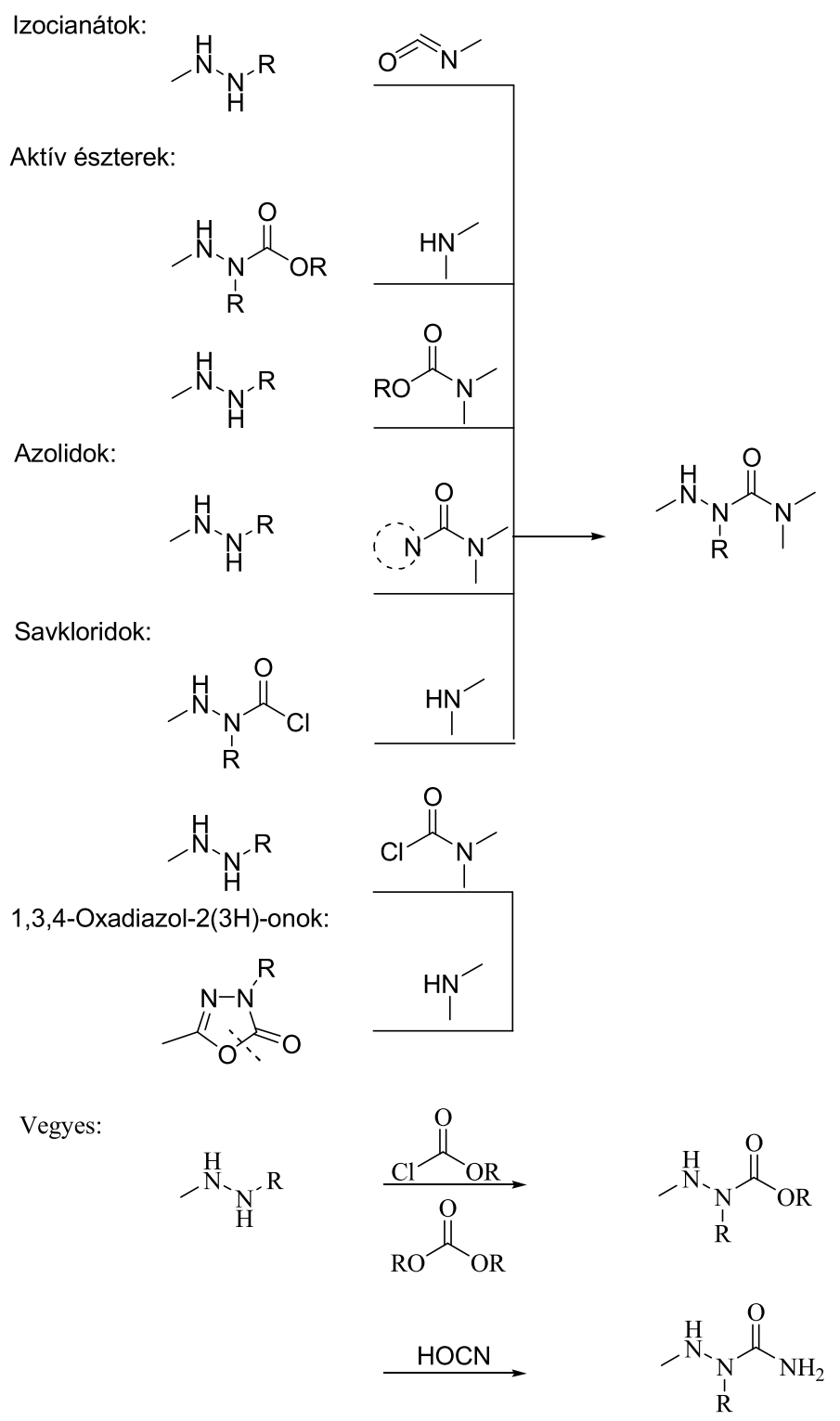

12. ábra: Azapeptidek szintézisének lehetőségei 
Maga az azaaminosav származékok előállítására legáltalánosabban alkalmazott séma (13. ábra) a védett karbazátokból indul ki, mint például a Boc-hidrazid (a). A szabad amino csoport monoalkilálására olyan karbonil komponenssel (b) reagáltatják, amely már tartalmazza a megfelelő aminosav oldalláncot. Hidrazont (c) képez, amely ezután hidrazinná $(\mathbf{d})$ redukálható.

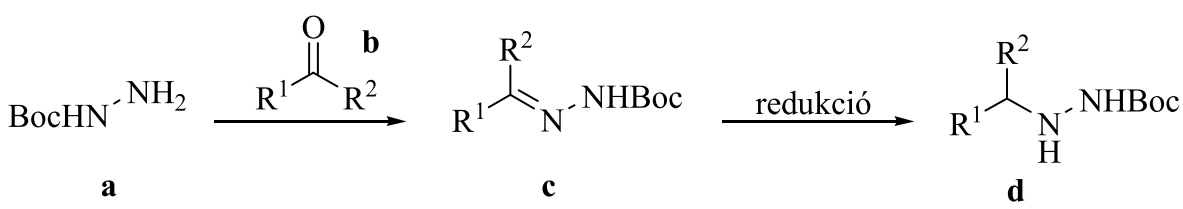

13. ábra: A védett hidrazid derivatizálása

A második karbonil csoport kialakítása (kiegészítve az azaaminosav szerkezetet) történhet alkil vagy aril kloroformáttal, ez esetben egy észter keletkezik, vagy izocianáttal, amikor egy amid keletkezik.

Az Ucn 3 (36-38) alapú 15a-c, illetve 16 peptidomimetikumoknál (7. táblázat) azaglutamin vagy a N-en glutamin oldalláncot tartalmazó építőkövekre volt szükség.

7. táblázat: A 15a-c, valamint a $\mathbf{1 6}$ analóg analitikai jellemzői

\begin{tabular}{|c|c|c|c|c|}
\hline Kód & $\begin{array}{c}\text { Analitikai HPLC } \\
\text { gradiens }\end{array}$ & $\begin{array}{c}\mathbf{t}_{\mathbf{R}}{ }^{*} \\
(\mathbf{p e r c})\end{array}$ & $\mathbf{M}_{\text {számított }}$ & $\begin{array}{c}\mathbf{M}_{\text {mért }^{\dagger}} \\
\left([\mathbf{M}+\mathbf{H}]^{+}\right)\end{array}$ \\
\hline $\mathbf{1 5 a}$ & $33-48(\% \mathrm{~B}) ; 15$ perc & 7.33 & 300.4 & 301 \\
\hline $\mathbf{1 5 b}$ & $5-25(\% \mathrm{~B}) ; 20$ perc & 9.89 & 259.3 & 331 \\
\hline $\mathbf{1 5 c}$ & $8-23(\% \mathrm{~B}) ; 15$ perc & 7.19 & 330.3 & 304 \\
\hline $\mathbf{1 6}$ & $36-51(\% \mathrm{~B}) ; 15$ perc & 8.87 & 303.3 & 260 \\
\hline
\end{tabular}

*: Retenciós idő meghatározása Agilent 1100 HPLC rendszeren (oszlop: Phenomenex Jupiter 10 $\mu \mathrm{m}$ C18

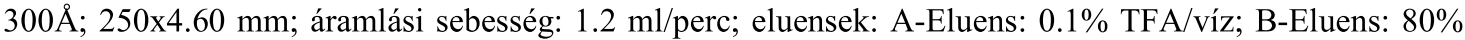
acetonitril $/ 20 \%$ víz/0.1\% TFA)

${ }^{\dagger}$ : MS $\left(\mathrm{ESI}^{+}\right): m / z$; monoizotópos molekulatömeg meghatározása Finnigan TSQ 7000 ESI-MS-en.

$\mathrm{Az}$ azaglutamin szintézise a fenti ábrán leírt szintézis úton nem vezetett eredményre, a szükséges aldehid: $\mathrm{R}^{1}=\mathrm{CH}_{2} \mathrm{CONH}_{2}, \mathrm{R}^{2}=\mathrm{H}$ lenne, de ennek előállítása rengeteg problémába ütközött. Végül Le Berre és társai által leírt szintézis úttal [85] sikerült előállítani a N-en glutamin oldalláncot tartalmazó építőköveket egy aza-Michael addícióval, melynek egyik partnere az akrilamid, a másik a megfelelő amin vagy Bocvédett hidrazid. A 17, 18, 20 építőkövek szintézisét Michael addícióval a 14. ábra mutatja be. 


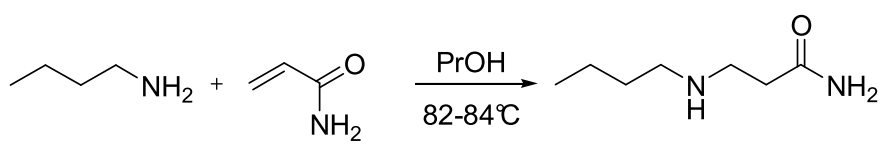

17

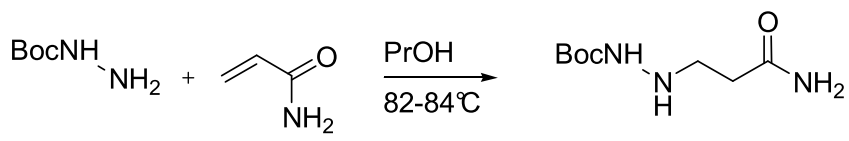

18

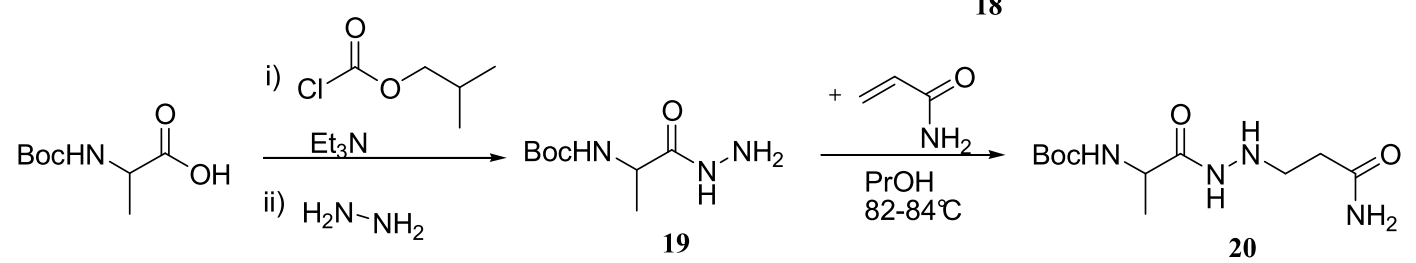

14. ábra: A 17, 18, 20 építőkövek szintézise

A 17-18 építőkövek szintéziséhez ekv. mennyiségü $n$-butilamint, ill. Bochidrazidot, valamint akrilamidot használtam. A reakciót vékony rétegen követtem, a termékeket kristályosítással tisztítottam.

A 20 építőkő szintéziséhez első lépésben kialakítjuk a terc-butiloxikarbonil-Lalanil-hidrazidot vegyes anhidrides módszerrel a Boc- $L$-Ala-OH és hidrazin reakciójával, majd egy aza-Michael addícióban reagáltatjuk ekv. mennyiségü akrilamiddal.

$\mathrm{Az}$ azaglutamint vagy $\mathrm{N}$-en glutamin oldalláncot tartalmazó peptidomimetikumok szintézise történhet szilárd fázison (15a-c) vagy oldat fázisban (16) [86, 87].
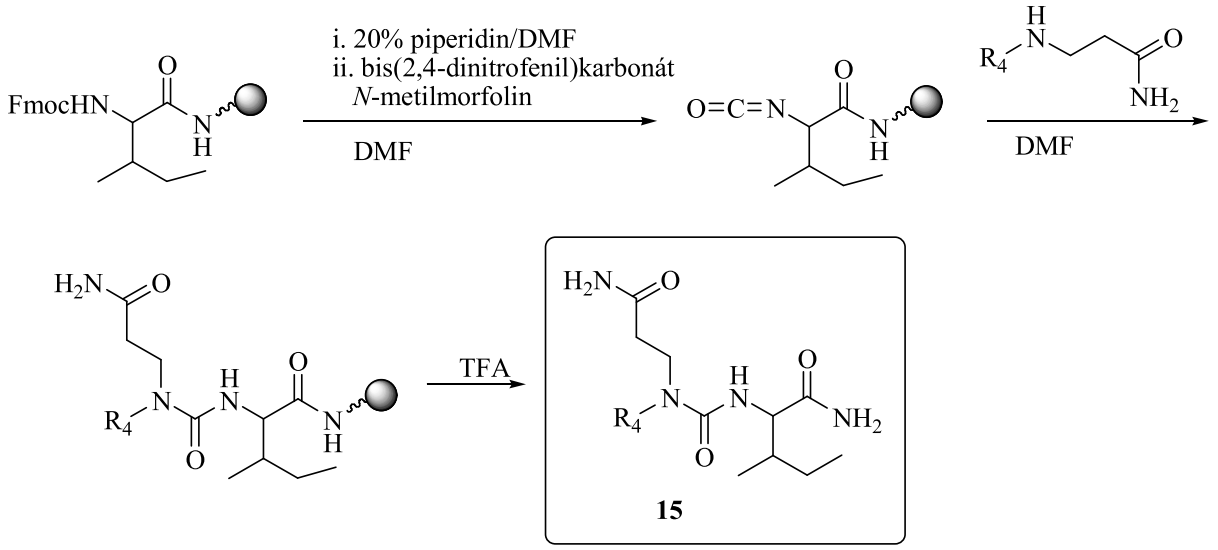<smiles>CCCCN(CCC(N)=O)C(=O)NC(C(N)=O)C(C)CC</smiles>

15a<smiles>CCC(C)C(NC(=O)N(N)CCC(N)=O)C(N)=O</smiles>

15b<smiles>CCC(C)C(NC(=O)N(CCC(N)=O)C(N)=O)C(=O)C(C)N</smiles>

$15 \mathrm{c}$

15. ábra: A 15a-c analógok előállítása és szerkezete 
A 15a-c analógok előállítását Rink amid hordozón végeztem Fmoc-kémiával. A gyantára kötött izoleucin szabad amino csoportját aktiváltam bis(2,4dinitrofenil)karbonáttal (21) $\mathrm{N}$-metilmorfolin jelenlétében és így kapcsoltam a $\mathrm{N}$-en glutamin oldalláncot tartalmazó építőköveket $(\mathbf{1 7}, \mathbf{1 8}, \mathbf{2 0})$. A kész analógokat a gyantáról 90 (v/v\%) TFA/víz elegyével hasítottam le, szemipreparatív RP-HPLC-vel tisztítottam és analitikailag jellemeztem retenciós idejük és molekulatömegük alapján (7. táblázat). A szintézis menetét, valamint az így előállított analógok szerkezetét a 15. ábra mutatja be.

Az aktiváláshoz használt bis(2,4-dinitrofenil)karbonátot (21) az irodalomból ismert difenil-karbonát nitrálásával állítottam elő [88] (16. ábra).

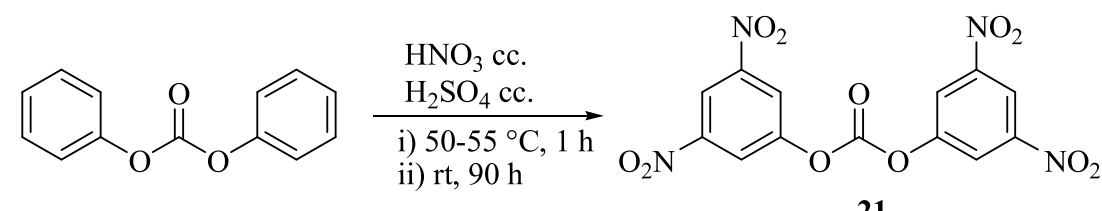

16. ábra: A bis(2,4-dinitrofenil)karbonát szintézise

A 16 analóg szintézisét oldat fázisban végeztem a 3-(terc-butiloxikarbonilhidrazino)propánsavamidból (18) kiindulva. Az acilezési reakcióhoz klórhangyasavizobutil észtert használtam trietilamin jelenlétében (17. ábra). A kész terméket szemipreparatív HPLC-vel tisztítottam, analitikai jellemzését a 7. táblázat foglalja össze.

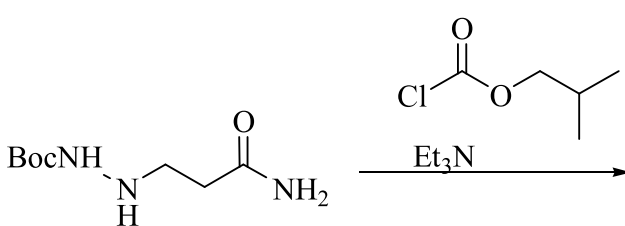

17. ábra: A $\mathbf{1 6}$ analóg szintézise

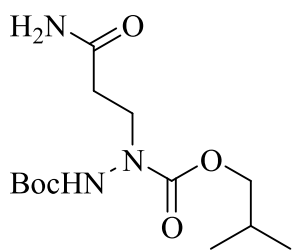

16

Az Ucn 3 analógok biológiai vizsgálata folyamatban van. Az eddigi eredmények alapján elmondható, hogy némelyek akár orális adagolásra is alkalmasnak bizonyultak.

\subsection{Orexinek hatása a vízanyagcserére, a vazopresszin kiválasztásra}

Két orexin neuropeptidet azonosítottak: az orexin A- és orexin B-t [53]. Az orexin A egy erősen konzervált szerkezettel rendelkező neuropeptid, amelyet 33 aminosav épít fel, szerkezetét két intermolekuláris diszulfid híd stabilizálja (18. ábra). Endogén ligandumként erösen kötődik a heptahelikális G-proteinhez kapcsolt OX1 és OX2 receptorokhoz. Az orexin B egy 28 aminosavas peptid, 46\%-ban mutat hasonlóságot az 
orexin A-val - ez többnyire a $C$-terminális részre korlátozódik. A két peptid ugyanabból a 130 aminosavas prekurzorból származik, a prepro-orexinből, azonban funkciójuk eltérő.

Laboratóriumunkban korábban előállították az orexin B-t (RSGPPGLQGRLQRL LQASGNHAAGILTM). Munkám során az orexin A szintézisét végeztem azzal a céllal, hogy az orexinek hatását vizsgáljuk a vízanyagcserére in vivo, a vazopresszin kiválasztásra in vitro körülmények között.

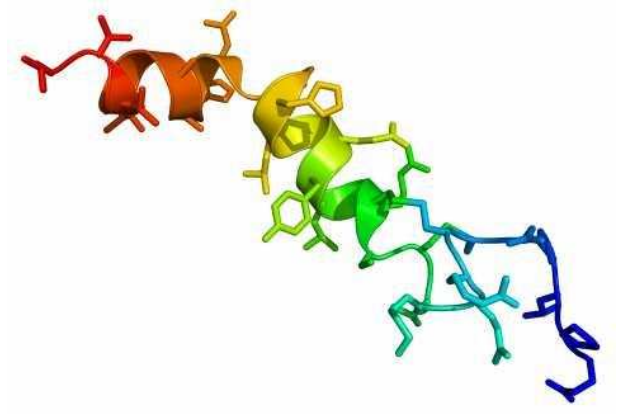

18. ábra: Az Orexin A szalagdiagramja

$\mathrm{Az}$ orexin A kémiai szintézise az irodalomból ismert, Söll és Beck-Sickinger szelektív Cys párosításokat alkalmaztak [89] Acm és Trt tiol védőcsoportokkal, azonban ez a módszer anyag- és időigényesnek bizonyult, ezért az Orexin A előállítására optimalizáltam a legegyszerübb módszert, az „oxidatív folding”-ot.

A lineáris orexin A (kód: $<$ EPTL) előállítása Rink amid-ChemMatrix ${ }^{\circledR}$ hordozón történt CEM mikrohullámú peptidszintetizátoron. Az automata peptidszintetizátor a Fmoc/tBu-stratégiát alkalmaz. A szintézis során felhasznált Fmoc-aminosav származékok TFA-ra érzékeny oldallánc védőcsoportokat tartalmaztak, a Fmoc védőcsoport hasítása 20 (v/v\%)-os piperidin/dimetilformamid elegyével történik. Az N-terminális piroglutaminsavat védőcsoport nélkül építettem be. Az aminosavak kapcsolásához 4-4 ekv. HATU és HOAt elegyét használtam DIEA jelenlétében. A kész peptidet a gyantáról TFA/víz/DTT/TIS 83:10:5:2 (v/v/m/v) arányú elegyével hasítottam le.

A szintézis protokoll optimalizálásához meghatároztam a szekvencia aggregációra hajlamos pontjait a Peptide Companion program segítségével, így döntöttem el, hogy az aminosavakat egyszeri vagy dupla kapcsolásokkal építsem be. A peptidet elöször egy 0.1 mmol-os mennyiségben szintetizáltam, így derült ki, hogy a Cys és His kapcsolására a gyártó által ajánlott $50^{\circ} \mathrm{C}$-os kapcsolási hömérséklet nagyon magas, az ajánlott kapcsolási idők viszont nagyon rövidek. A peptid hasítás után is nagyon érzékenynek bizonyult, 
szobahőmérsékleten levegő hatására rövid idő alatt elindultak a ciklizálási folyamatok, egy izomer keveréket eredményezve. Ezért tértem át a 0.5 mmol-os szintézis során a hosszabb kapcsolási időkre és az alacsonyabb kapcsolási hőmérsékletre $\left(35^{\circ} \mathrm{C}\right)$, valamint hasítás után a szabad oldalláncokkal rendelkező peptidet azonnal savanyítottam (bázikus körülmények között gyorsabb az oxidáció) és liofilizáltam. Az optimalizált CEM szintézisprotokollt a 25. táblázat (ld. 5.2 fejezet) foglalja össze.

$\mathrm{Az}$ „oxidatív folding” kísérletekhez a nyers lineáris peptid kis részleteit használtam. A kísérletek során változtattam a peptidkoncentrációt: $0.5 \mathrm{mg} / \mathrm{ml}, 1 \mathrm{mg} / \mathrm{ml}$; a reakcióközeget: víz, ammónium-acetát puffer $(\mathrm{pH}$ 6.5, $\mathrm{pH}$ 7.5), glikokoll-NaOH puffer ( $\mathrm{pH}$ 8.9), Tris- $\mathrm{HCl}$ puffer ( $\mathrm{pH} 8.4$ ), valamint az oxidálószert: levegő, jód, dimetilszulfoxid, redox puffer (cisztein/cisztin), Clear-ox ${ }^{\text {TM }}$ gyanta. A reakcióelegyből 5, majd 30 percenként mintát vettem, ezt esetenként 10 (v/v\%)-os ecetsavval savanyítottam és analitikai RP-HPLC-re injektáltam, majd az oszlopról eluálódó csúcsokat ESI-MS-el ellenőriztem.

A natív izomer azonosítása a kereskedelemben kapható orexin A-val történő kromatográfiás összehasonlítás révén történt. A kísérletek során különböző ciklizált izomerek eltérő arányú keverékét kaptam. A jódos ciklizálás három izomer közel egyenlő arányú keverékét, a levegőn Gly-NaOH (pH 8.9) pufferben végzett oxidáció két izomer közel egyenlő arányú keverékét eredményezte. A többségében natív izomert a DMSOdal, a redox pufferben, valamint a Clear-ox ${ }^{\mathrm{TM}}$ gyantával végzett oxidáció eredményezte közel hasonló arányban (19. ábra).
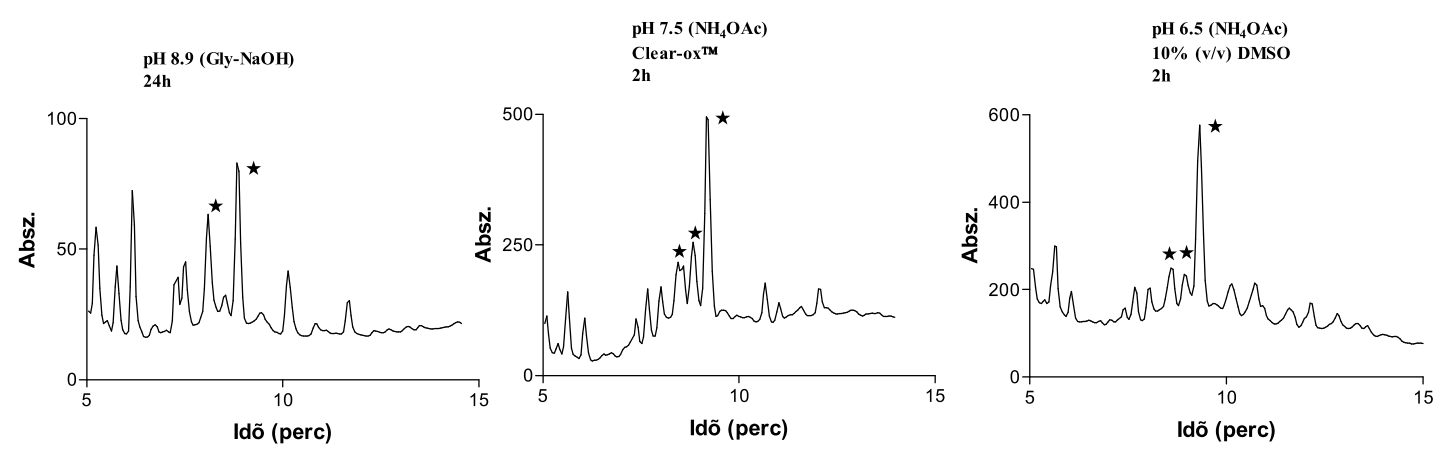

19. ábra: Néhány ciklizálási kísérlet kromatogramja ( ${ }^{*}$ : ciklizált izomer)

$\mathrm{Az}$ orexin A nagyobb mennyiségű izolálására a Clear-ox ${ }^{\mathrm{TM}}$ gyantával történő ciklizálást választottam, mert ezzel a módszerrel teljes mértékben elkerülhetők a 
kromatográfiás tisztítást zavaró tényezők, mint a maradék oxidálószer vagy a használt puffer sótartalma.

A Clear-ox ${ }^{\mathrm{TM}}$ gyanta tulajdonképpen egy szilárd hordozóhoz kapcsolt oxidálószer, a ciklizálás mechanizmusát a 20. ábra mutatja be. Az oxidálószer szintéziséhez tulajdonképpen egy amid végü hordozóra kötik a Lys-t és hozzákapcsolják az aminosav két szabad aminocsoportjához az 5,5'-ditiobis(nitrobenzoesav)-at.

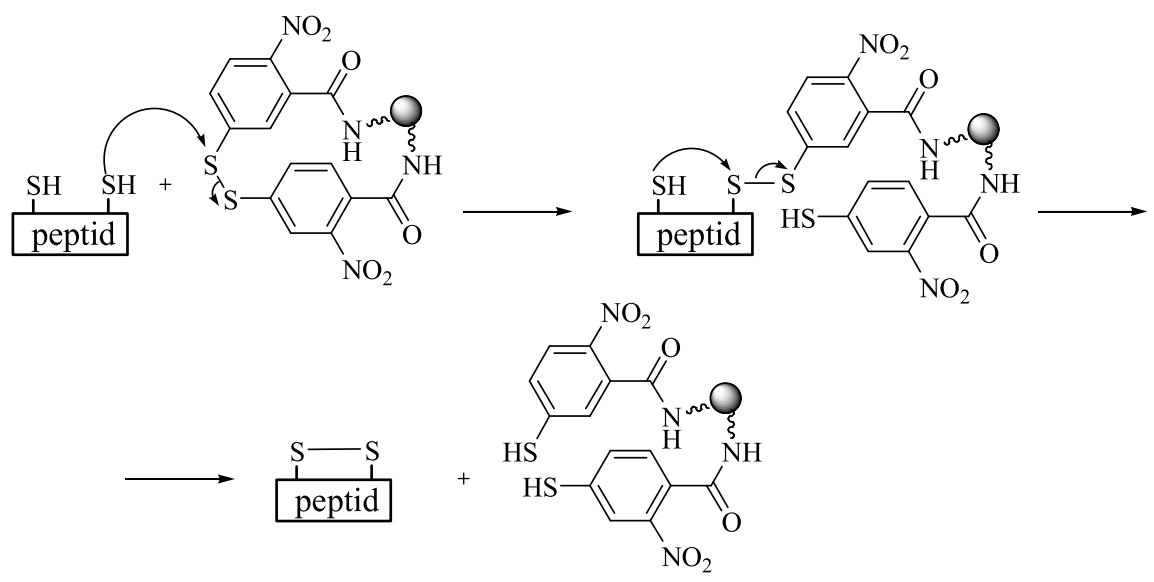

20. ábra: Ciklizálás Clear-ox ${ }^{\mathrm{TM}}$ gyantával

A hordozó nagy előnye, hogy a ciklizálás végén regenerálható, rendkívül enyhe körülmények között használható, a nehezen oldódó peptidek esetén acetonitrilt is adhatunk a reakcióelegyhez, valamint az oxidáció végén a fölösleg egyszerü szüréssel eltávolítható.

A keletkező nyers ciklizált terméket szemipreparatív RP-HPLC-vel tisztítottam, az izolált orexin A-t kromatográfiásan és tömegspektrometriásan jellemeztem (8. táblázat, 21. ábra).

8. táblázat: A lineáris és ciklizált neuropeptid analitikai paraméterei

\begin{tabular}{|c|c|c|c|c|c|}
\hline Kód & Szekvencia & $\begin{array}{c}\text { Anal.HPLC } \\
\text { gradiens }\end{array}$ & $\begin{array}{c}\mathbf{t}_{\mathbf{R}}{ }^{*} \\
(\mathbf{p e r c})\end{array}$ & $\mathbf{M}_{\text {számított }}$ & $\begin{array}{c}\mathbf{M}_{\text {mért }^{\dagger}} \\
\left(\left[\mathbf{M}+\mathbf{H}^{+}\right)\right.\end{array}$ \\
\hline <EPTL & $<$ EPLDCCRQKTCSCRLYELLHGAGNHAAGILTL-NH & $\begin{array}{c}35-55(\% \mathrm{~B}) ; \\
20 \text { perc }\end{array}$ & 9.42 & 3565.1 & 3566 \\
\hline $\begin{array}{c}\text { Orexin } \\
\text { A }\end{array}$ & $\begin{array}{c}<\text { EPLDCCRQKTCSCRLYELLHGAGNHAAGILTL-NH } \\
\text { L }\end{array}$ & $\begin{array}{c}37-52(\% \mathrm{~B}) ; \\
20 \text { perc }\end{array}$ & 6.36 & 3561.1 & 3562 \\
\hline
\end{tabular}

*: Retenciós idő meghatározása Agilent 1200 HPLC rendszeren (oszlop: Phenomenex Jupiter 10 $\mu \mathrm{m}$ C18 300Å; 250x4.60 mm; áramlási sebesség: $1.2 \mathrm{ml} /$ perc; eluensek: A-Eluens: 0.1\% TFA/víz; B-Eluens: $80 \%$ acetonitril $/ 20 \%$ víz/ $0.1 \%$ TFA)

${ }^{\dagger}$ : MS (ESI ${ }^{+}$: $m / z$; monoizotópos molekulatömeg meghatározása Finnigan TSQ 7000 ESI-MS-en. 


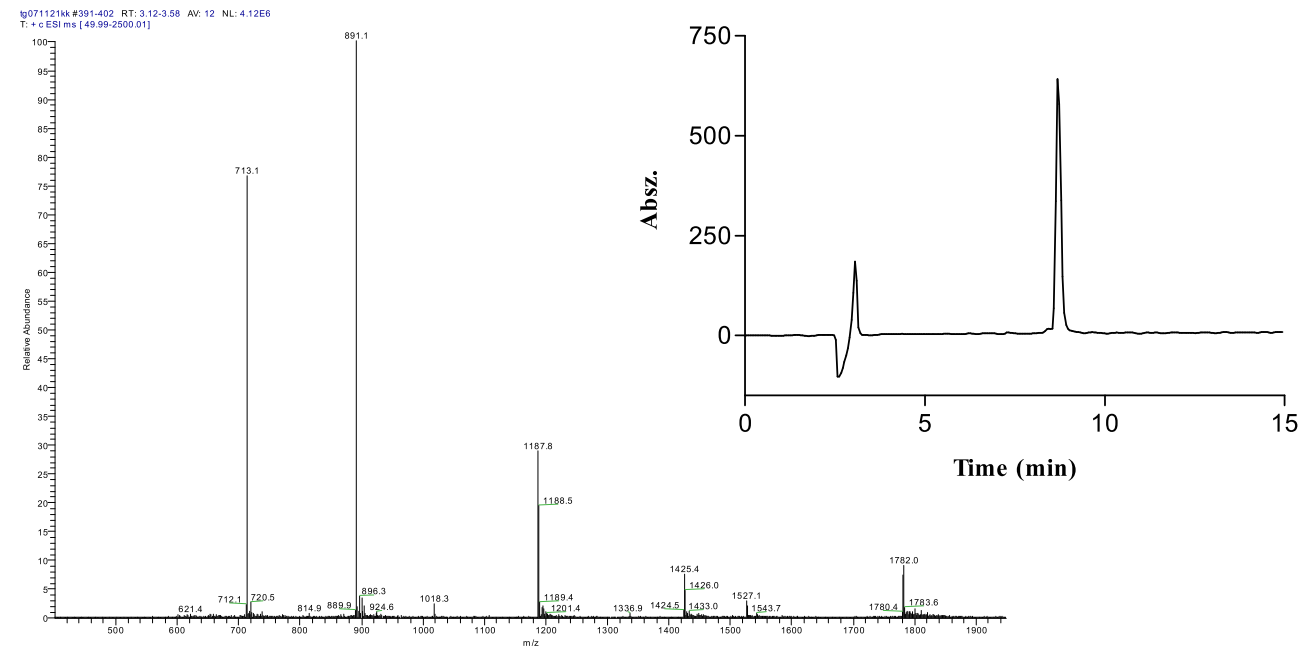

21. ábra: A tisztított Orexin A kromatogramja és ESI-MS spektruma

A biológiai vizsgálatok során László és munkatársai megállapították, hogy az orexin A-t közvetlenül agykamrába adva (intracerebroventrikuláris, i.c.v.) fokozódik a patkányok táplálék- és vízfelvétele, nő a vizeletürítésük. Intraperitoniális (i.p.) bejutást követően ezek a változások nem mutathatóak ki. A szérum vazopresszin szintet radioimmunoesszé (RIA) segítségével mérték; 10, 30 ill. $90 \mu \mathrm{g}$ orexin A i.c.v. adagolás után nem találtak eltérést a vazopresszin koncentrációban. Az adatok alapján feltételezhető, hogy a polidipszia ill. a poliuria a vazopresszin rendszertől függetlenül jön létre.

Előzetes vizsgálatok során [90] kimutatták, hogy a Gálfi és munkatársai által kidolgozott izolált neurohipofízis sejtkultúra felülúszó médiumában az inkubációt követő 14-16. napon jelentős vazopresszin kiválasztás történik. Bazális körülmények között 10${ }^{10}-10^{-6} \mathrm{~mol} / \mathrm{dm}^{3}$ orexin A ill. orexin $\mathrm{B}$ hatására a neurohipofízis sejtkultúra felülúszó médiumában vazopresszin szint változást nem észleltek.

László és munkatársai több közleményben beszámoltak arról, hogy a monoaminerg vegyületek (adrenalin, noradrenalin, dopamin, hisztamin, szerotonin) növelik a neurohipofízis sejtkultúra felülúszó médiumában a vazopresszin kiválasztást [91, 92]. A monoaminerg vegyületek vazopresszin szekréció fokozó hatása mérséklődik $10^{-6} \mathrm{~mol} / \mathrm{dm}^{3}$ orexin A ill. orexin B előzetes bejuttatásával. Legkifejezettebb csökkenést a noradrenalin, ill. a hisztamin adagolás előtt alkalmazott orexin A és B idézett elő. Nem észleltek változást a nem specifikus kiválasztást fokozó $\mathrm{K}^{+}$bejuttatása előtt alkalmazott orexin A és B hatására. Az in vitro vizsgálatok eredményei felvetik azt a lehetőséget, 
hogy a vazopresszin szekréciót növelő anyagok (állapotok) hatásának orexin okozta mérséklése szerepet játszhat a polidipszia, poliuria kifejlődésében.

\subsection{Szelektív Kv1.3 ioncsatorna gátló szerek előállítása és vizsgálata}

$\mathrm{Az}$ Anuroctonus phaiodactylus-ból izolált anuroctoxin, illetve a Tityus cambridgei-ből izolált Tc32 skorpió toxinok nagymértékü szelektivitást mutatnak biológiai vizsgálatokban a Kv1.3 ioncsatorna iránt. Célul tüztük ki előállításukat, majd esetlegesen pontmutációkkal nagyobb szelektivitású módosított változataiknak szintézisét.

3.3.1. A natív anuroctoxin elóállítása és biológiai vizsgálata

$\mathrm{Az}$ anuroctoxin (AnTx) a Mexikóban honos Anuroctonus phaiodactylus skorpióból izolált 35 aminosavból álló peptid, melyet 4 diszulfid híd stabilizál. A skorpió toxinok $\alpha$-KTx 6-os altípusához tartozik és bizonyítottan szelektíven blokkolja a humán T limfociták Kv1.3 ioncsatornáit az IKCa1 ioncsatornákhoz viszonyítva. Mindkét csatorna fontos, de eltérő szerepet játszik a $\mathrm{T}$ limfociták aktiválásában. Az anuroctoxin 3D szerkezetéből megállapítható, hogy hasonlóan a ChTx-hez, a csatornához való kötődésben fontos szerepet játszó két aminosav (K23, F32) megfelelő térbeli orientációban van, azaz az anuroctoxin esetén kialakul az „esszenciális diád”.
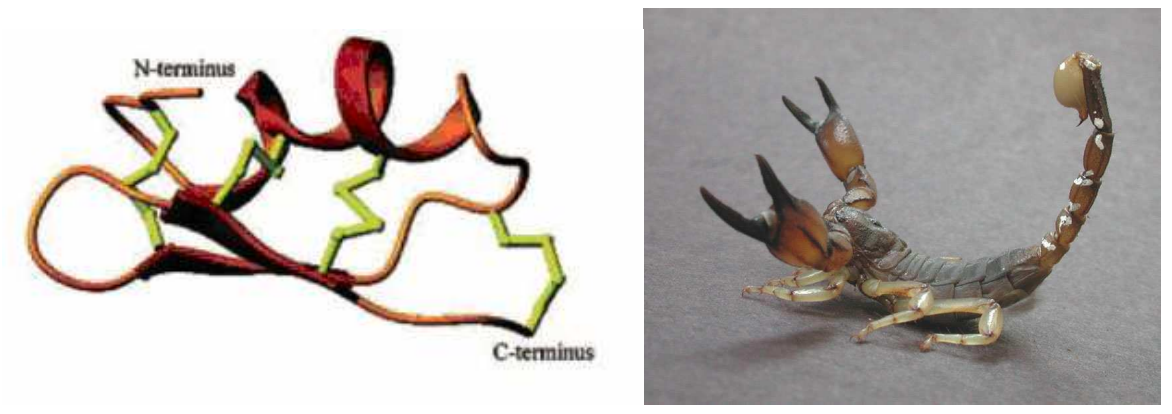

22. ábra: Az anuroctoxin szalagdiagramja (bal) és az Anuroctonus phaiodactylus skorpió, amelyből izolálták a toxint (jobb)

Panyi és társai már korábban azonosították a skorpióból izolált toxint, mint hatékony Kv1.3 csatorna gátlószert [93]. Az AnTx szelektivitását vizsgálták több ioncsatornán (23. ábra) és megállapították, hogy 730 pM-os disszociációs állandóval gátolja a Kv1.3 csatornát. Bár több $\mathrm{K}^{+}$csatornán hatástalan volt az AnTx, a Kv1.3 mellett 
az ideg- és izomsejtekben megtalálható Kv1.2 csatornát is gátolta kisebb affinitással $\left(\mathrm{K}_{\mathrm{d}}\right.$ $=6 \mathrm{nM})$, ́́gy a szelektivitási kritériumnak nem felelt meg.

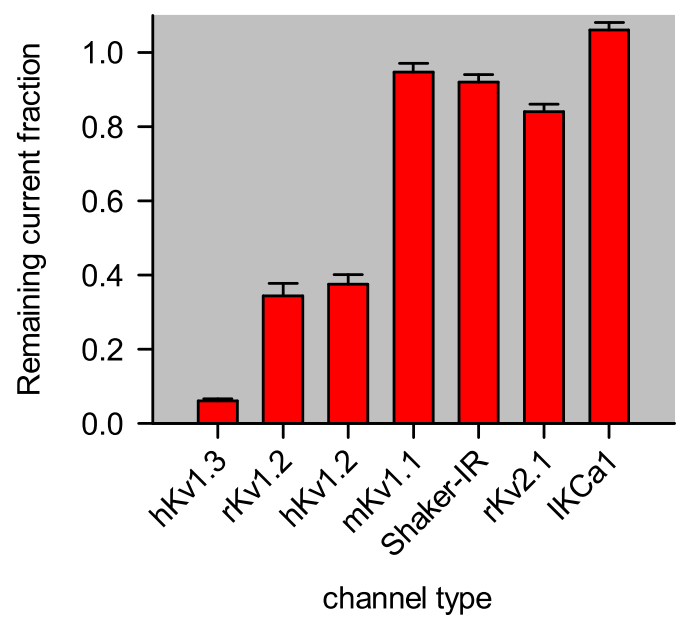

23. ábra: Az AnTx szelektivitási vizsgálatának eredménye. Az ábrán $10 \mathrm{nM}$ AnTx jelenlétében számított megmaradó áramhányadok láthatóak a Kv1.3, IKCa1, Shaker IR, rKv2.1, mKv1.2 és hKv1.2 csatornák esetében. A megmaradó áramhányadot a toxin jelenlétében, valamint kontroll körülmények között mért csúcsáramok hányadosaként számították. Minden esetben négy független mérést végeztek, az eredményt átlag \pm SEM formában adták meg.

Ezek alapján célul tüztük ki az AnTx szelektivitásának javítását az affinitás megtartása, vagy akár további javítása mellett. Ennek első lépése volt a natív izomer előállítása szintetikus módon.

A lineáris AnTx (kód: <EKCK) előállítását manuális szilárd fázisú peptidszintézis módszerével valósítottam meg Boc-Lys(2ClZ)-PAM hordozón Boc/Bzl-stratégiával. A felhasznált aminosavak mindegyike hidrogén-fluoridra érzékeny oldallánc védőcsoporttal rendelkezett. $\mathrm{Az} N$-terminális piroglutaminsavat oldallánc védőcsoport nélkül építettem be. A kapcsolásokhoz 3-3 ekv. Boc aminosav származékot, DCC-t és HOBt-t használtam. A kész peptidet a gyantáról folyékony hidrogén-fluoriddal hasítottam le, gyökfogóként anizolt, dimetil-szulfidot, $p$-krezolt és DTT-t használtam.

A lineáris anuroctoxin ciklizálásához „oxidatív folding”-ot használtam. Az oxidáció optimalizálásához próbareakciókat végeztem a nyers lineáris peptid kis mennyiségeivel. A reakciókban változtattam a peptidkoncentrációt $(0.5 \mathrm{mg} / \mathrm{ml}$ vagy 1 $\mathrm{mg} / \mathrm{ml}$ ), az oldat pH-ját (6.5-8.7), valamint az oxidálószert (levegő, DMSO, redox puffer: cisztein/cisztin). 

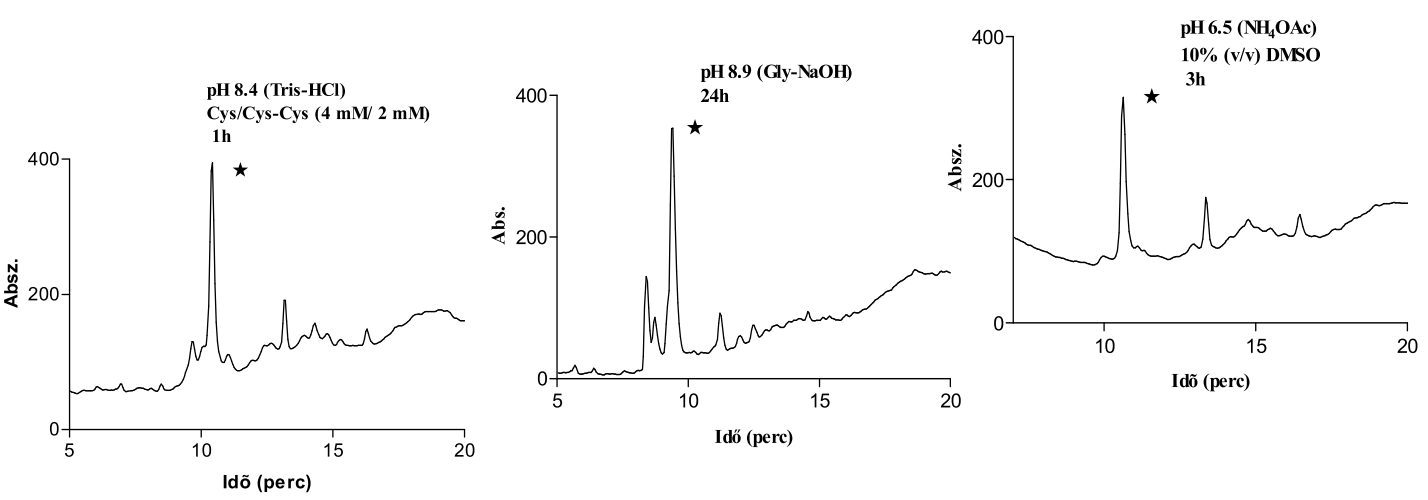

24. ábra: Néhány ciklizálási kísérlet kromatogramja ( ${ }^{*}$ : ciklizált izomer)

A feltekeredési kísérletek mindegyike közel azonos mértékben egyetlen föterméket eredményezett. A leggyorsabb átalakulás redox pufferben történt, de a legszelektívebb módszernek a $10(\mathrm{v} / \mathrm{v} \%)$ DMSO bizonyult ammónium-acetát pufferben (pH 6.5).

9. táblázat: A lineáris és a ciklizált anuroctoxin analitikai jellemzői

\begin{tabular}{|c|c|c|c|c|}
\hline Kód & Szekvencia & $\begin{array}{c}\mathbf{t}_{\mathbf{R}}{ }^{*} \\
\text { (perc) }\end{array}$ & $\mathbf{M}_{\text {számított }}$ & $\begin{array}{c}\mathbf{M}_{\text {mért }^{\dagger}} \\
\left([\mathbf{M}+\mathbf{H}]^{+}\right)\end{array}$ \\
\hline <EKCK & <EKECTGPQHCTNFCRKNKCTHGKCMNRKCKCFNCK-OH & 12.43 & 4108.8 & 4109 \\
\hline $\begin{array}{c}\text { Anuroctoxin } \\
(\text { AnTx) }\end{array}$ & <EKECTGPQHCCNFCRKNKCTHGKCMNRKCKCFNCK-OH & 9.22 & 4100.8 & 4101 \\
\hline
\end{tabular}

*: Retenciós idő meghatározása Agilent 1100 HPLC rendszeren (oszlop: Phenomenex Jupiter $5 \mu$ m C18(2) $100 \AA ; 250 \times 4.60 \mathrm{~mm}$; áramlási sebesség: $1.2 \mathrm{ml} /$ perc; gradiens: 10-30\% (B); 20 perc; eluensek: A-Eluens: $0.1 \%$ TFA/víz; B-Eluens: $80 \%$ acetonitril $/ 20 \%$ víz/0.1\% TFA)

${ }^{\dagger}: \mathrm{MS}\left(\mathrm{ESI}^{+}\right): \mathrm{m} / z$; monoizotópos molekulatömeg meghatározása Finnigan TSQ 7000 ESI-MS-en.

A toxin izolálásához a legegyszerübb módszert, a bázikus pufferben levegőn történő oxidációt választottam, mert így nem kerül az elegybe a kromatográfiás elválasztást esetlegesen zavaró tényező. A tisztított toxin analitikai jellemzőit a 9. táblázat és a 25. ábra foglalja össze. 


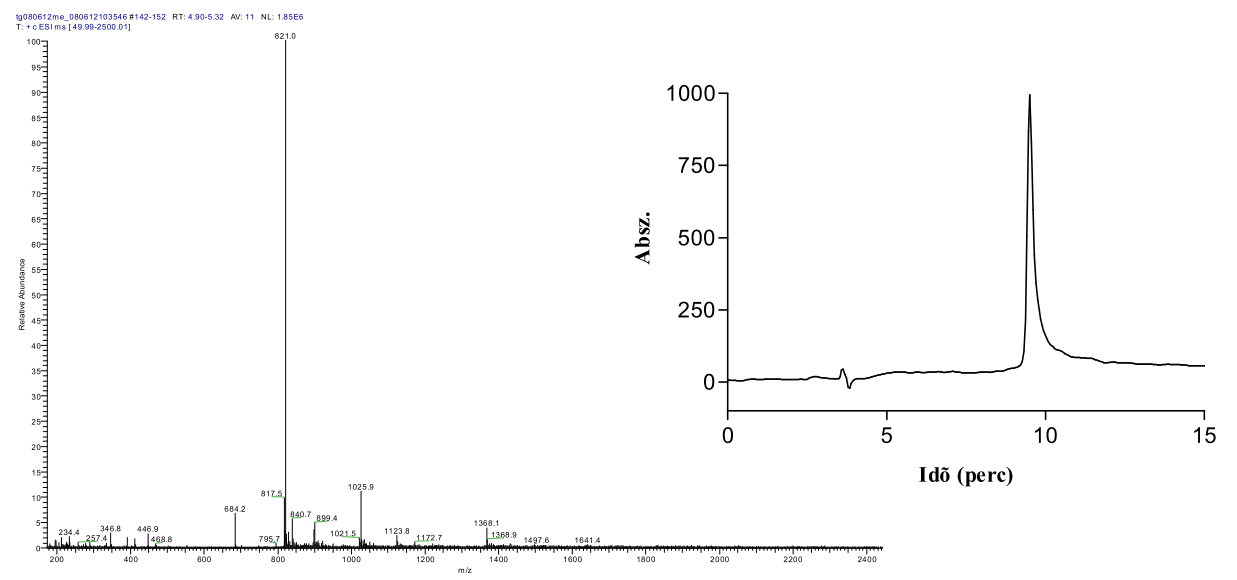

25. ábra: A tisztított anuroctoxin kromatogramja és ESI-MS spektruma

Az általam szintetizált izomer akkor tekinthető a natív izomerrel azonosnak, ha elektrofiziológiai tulajdonságai megegyeznek a természetes peptid tulajdonságaival. A megfelelő regioszelektivitást igazoló kísérleteket a 26. ábra mutatja be.

A)
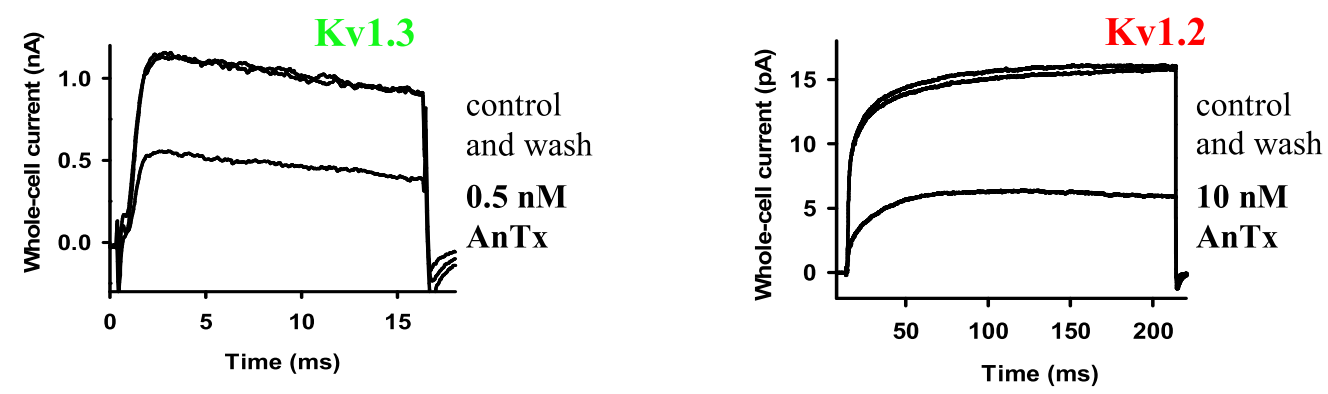

B)
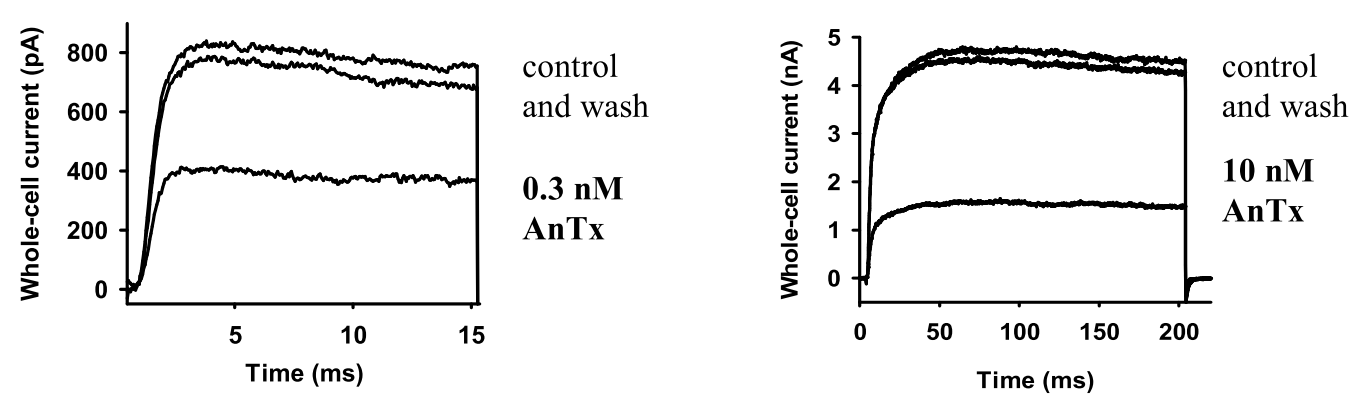

26. ábra: A természetes (A) és a szintetikus (B) anuroctoxin tulajdonságai megegyeznek. A reprezentatív áramgörbék a toxin adása előtti (kontroll), AnTx-nal történő blokkolás utáni és a toxinmentes extracelluláris oldat újbóli perfúziója (kimosás) után mért $\mathrm{K}^{+}$áramokat mutatják az egyensúlyi állapot beállta után. Az áramokat perifériás T-limfocitán mértük $-120 \mathrm{mV}$-os tartófeszültség mellett, $+50 \mathrm{mV}$ tesztimpulzust alkalmazva. A tesztimpulzusok között $40 \mathrm{~s}$ telt el.

3.3.2. Növelt szelektivitású anuroctoxin mutánsok előállítása és biológiai vizsgálata

Ahhoz, hogy egy toxin potenciálisan terápiás felhasználásra kerülhessen igen lényeges, hogy lehetőleg egy, a célsejt megfelelő funkciójában szerepet játszó 
csatornafajtát gátoljon a többi csatorna müködésének befolyásolása nélkül.

$\mathrm{Az}$ in vivo (patkány modell) kísérletek alapján Sclerosis Multiplex neurodegeneratív betegségben szenvedő betegek véréből, illetve a központi idegrendszeri károsodás helyén is sikerült kimutatni a $\mathrm{Kv} 1.3^{\text {high }} \mathrm{IKCa} 1^{\text {low }}$ csatorna fenotípussal rendelkező, krónikusan aktivált $\mathrm{T}_{\mathrm{EM}}$ sejteket. A várakozásnak megfelelően a Kv1.3 nagy affinitású gátlószerei a $\mathrm{T}_{\mathrm{EM}}$ sejtek osztódását specifikusan gátolták, míg a Kv1.3 blokkolás által mediált proliferáció gátlás alól a nyugvó és centrális memória T-sejtek az IKCa1 csatornák fokozott expressziójával mentesülnek. Így a Kv1.3 szelektív inhibitorai ezen in vitro kísérletek alapján specifikus immunszupressziót okozhatnak.

Célunk volt tehát a toxin szelektivitásának növelése a Kv1.3 csatorna iránt a Kv1.2 csatornához képest. Ezt úgy értük el, hogy a toxin szekvenciájában célzott helyeken aminosav-cseréket végeztünk. A mutációk helyének és természetének megtervezéséhez Panyi és munkatársai az irodalomból és a debreceni kollégák saját eredményeiböl ismert toxinok szekvenciáját és szelektivitását összehasonlító analizisét végezték el [94] (10. táblázat).

10. táblázat: $\mathrm{A} \mathrm{K}^{+}$csatorna blokkoló toxinok szekvenciája és szelektivitása

\begin{tabular}{|lrccc|}
\hline & \multicolumn{1}{c}{ Peptide } & \multicolumn{2}{c|}{$\mathrm{K}_{\mathrm{d}}$ ratio } & \multicolumn{2}{c|}{$\mathrm{K}_{\mathrm{d}}(\mathrm{nM})$} \\
name & 1234567890123456789012345678901234567890 & Kv1.2/Kv1.3 & Kv1.2 & Kv1.3 \\
\hline maurotoxin & VSCTGSKDCYAPCRKQTGCPNA-KCINKSCKCYGC & $2 \mathrm{e}-4$ & 0.7 & 3300 \\
CoTX1 & AVCVYRT-CDKDCKRR-GYRSG-KCINNACKCYPY & 0.005 & 27 & 5300 \\
Pi4 & IEAIRCGGSRDCYRPCQKRTGCPNA-KCINKTCKCYGCS & $<8 \mathrm{e}-7$ & 0.008 & $>10000$ \\
Pi1 & LVKCRGTSDCGRPCQQQTGCPNS-KCINRMCKCYGC & 0.09 & 1 & 11 \\
\hline Css20-3 & IFINVKCSSPQQCLKPCKAAFGISAGGKCINGKCKCYP & 0.2 & 1.5 & 7.2 \\
Noxiustoxin & TIINVKCTSPKQCSKPCKELYGSSAGAKCMNGKCKCYNN & 2 & 2 & 1 \\
Hongotoxin-1 & TVIDVKCTSPKQCLPPCKAQFGIRAGAKCMNGKCKCYPH & 1.9 & 0.17 & 0.09 \\
ChTX & EFTNVSCTTSKECWSVCQRLHNTSRG-KCMNKKCRCYS & 5.4 & 14 & 2.6 \\
\hline anuroctoxin & ZKECTGPQHCTNFCRKN-KCTHG-KCMNRKCKCFNCK & 9 & 6 & 0.7 \\
OSK1 & GVIINVKCKISRQCLEPCKKA-GMRFG-KCMNGKCHCTPK & 386 & 5.4 & 0.014 \\
OSK1-20 & GVIINVKCKISRQCLEPCKDA-GMRFG-KCMNGKCHCTPK & 2108 & 78 & 0.037 \\
KTX & GVEINVKCSGSPQCLKPCKDA-GMRFG-KCMNRKCHCTPK & $>1538$ & $>1000$ & 0.65 \\
\hline
\end{tabular}
G

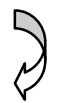
(
K16 $\rightarrow$ D16 N17 $\rightarrow$ A17
F32 $\rightarrow$ T32

A módosított toxin szekvenciáiban megmaradtak a toxin és a csatorna közötti kölcsönhatásban részt vevő aminosavak (27. ábra). 

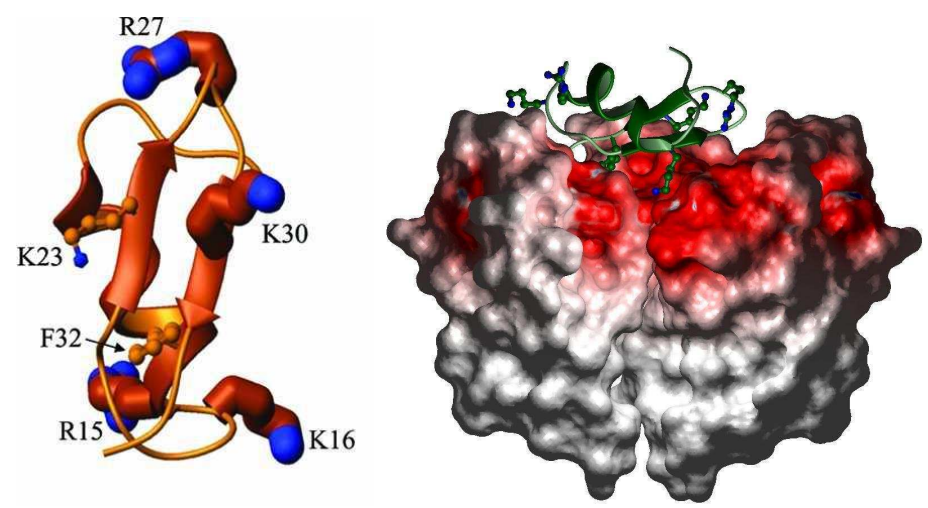

27. ábra: Az anuroctoxin szalagdiagramja kiemelve az „esszenciális diád” aminosavait (bal) és a toxin Kv1.3 ioncsatornára vetített képe (jobb)

Az általam szintetizált anuroctoxin analógokat a 11. táblázat foglalja össze.

11. táblázat: A módosított anuroctoxin szekvenciák

\begin{tabular}{|l|l|}
\hline \multicolumn{1}{|c|}{ Kód } & <EKECTGPQHCTNFCRKNKCTHGKCMNRKCKCFNCK-OH \\
\hline Anuroctoxin (AnTx) & $<$ EKECTGPQHCTNFCRKNKCTHGKCMNRKCKCTNCK-OH \\
\hline AnTx F32T, K16D & $<$ EKECTGPQHCTNFCRDNKCTHGKCMNRKCKCTNCK-OH \\
\hline AnTx F32T, N17A & $<$ EKECTGPQHCTNFCRKAKCTHGKCMNRKCKCTNCK-OH \\
\hline AnTx F32T, K16D, N17A & $<$ EKECTGPQHCTNFCRDAKCTHGKCMNRKCKCTNCK-OH \\
\hline
\end{tabular}

A pontmutációkkal létrehozott anuroctoxin analógok mindegyike $\mathrm{Fmoc} / \mathrm{Bu}-$ stratégiával készült TentaGel $\mathrm{R}$ PHB hordozón CEM mikrohullámú peptid szintetizátoron. A peptidlánc felépítéséhez használt aminosavak mindegyike TFA-ra érzékeny oldallánc védőcsoportot tartalmazott. Az $N$-terminális piroglutamint védőcsoport nélkül építettem be. Az aminosavak kapcsolásához 4-4 ekv. Fmoc-aminosav származékot, HBTU-t és HOBt-t használtam. A Fmoc-védett aminosavszármazékokról a 
Fmoc védőcsoportot 20 (v/v\%)-os piperidin/DMF elegyével hasítjuk le. Az optimalizált CEM protokollt a 26. táblázat (ld. 5.4. fejezet) foglalja össze. A peptideket a hordozóról TFA/víz/DTT/TIS 83:10:5:2 arányú elegyével hasítottam.

Az analógok oxidálására a natív izomernél is használt „oxidatív folding” körülményeit használtam: bázikus $\mathrm{Gly}-\mathrm{NaOH}$ pufferben $(\mathrm{pH} 8.7)$ oxidáltam levegőn a nyers lineáris peptideket. A ciklizált termékeket szemipreparatív RP-HPLC-vel tisztítottam, analitikai jellemzésüket retenciós idejük és molekulatömegük mérésével végeztem (12. táblázat).

12. táblázat: Az anuroctoxin mutánsok analitikai paraméterei

\begin{tabular}{|l|c|c|c|c|}
\hline \multicolumn{1}{|c|}{ Kód } & $\begin{array}{c}\text { Analitikai HPLC } \\
\text { gradiens (\% B) }\end{array}$ & $\begin{array}{c}\mathbf{t}_{\mathbf{R}}{ }^{*} \\
(\text { perc })\end{array}$ & $\mathbf{M}_{\text {számított }}$ & $\begin{array}{c}\mathbf{M}_{\text {mért }^{\dagger}} \\
\left(\left[\mathbf{M}^{\dagger} \mathbf{H}^{+}\right]^{+}\right.\end{array}$ \\
\hline AnTx F32T & $10-25(\% \mathrm{~B}) ; 15$ perc & 8.58 & 4036.7 & 4037 \\
\hline AnTx F32T, K16D & $10-25(\% \mathrm{~B}) ; 15$ perc & 8.46 & 4024.6 & 4025 \\
\hline AnTx F32T, N17A & $10-25(\% \mathrm{~B}) ; 15$ perc & 10.92 & 3999.7 & 4000 \\
\hline AnTx F32T, K16D, N17A & $10-30(\% \mathrm{~B}) ; 20$ perc & 11.73 & 3981.5 & 3982 \\
\hline AnTx F32T, K16D, N17A, <E1AAAN & $10-30(\% B) ; 20$ perc & 8.08 & 4197.8 & 4198 \\
\hline
\end{tabular}

": Retenciós idő meghatározása Agilent 1100 HPLC rendszeren (oszlop: Phenomenex Luna 5 $\mu \mathrm{m}$ C18(2)

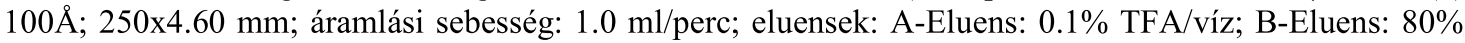
acetonitril $/ 20 \%$ víz/0.1\% TFA)

${ }^{\dagger}$ : MS (ESI ${ }^{+}$): $m / z$; monoizotópos molekulatömeg meghatározása Finnigan TSQ 7000 ESI-MS-en.

Az elkészült AnTx analógok közül az első három került tesztelésre, a többi biológiai vizsgálata még folyamatban van.

Mindhárom toxin (AnTx F32T, AnTx F32T K16D, AnTx F32T N17A) szelektivitása drámaian javult a vad-típusúhoz képest, ugyanakkor a Kv1.3 iránti affinitásuk kis mértékben csökkent (28. ábra).
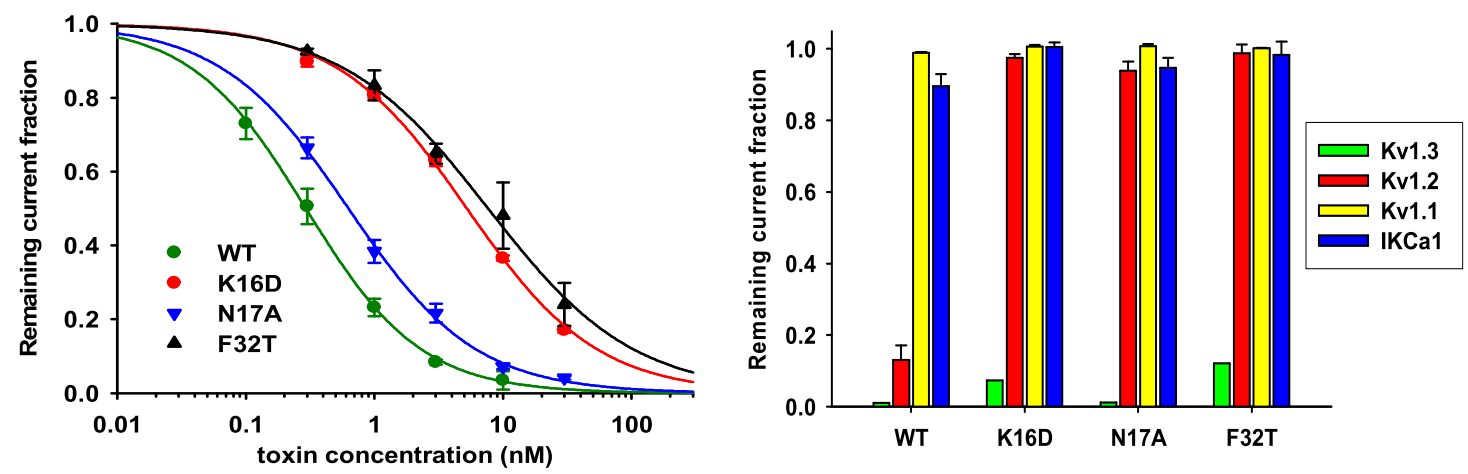

28. ábra: $\mathrm{A} \mathrm{K}^{+}$csatorna gátlás dózisfüggése (bal) és a toxinok szelektivitási vizsgálatának eredménye (jobb) 
A legjobb tulajdonságú toxin (AnTx F32T N17A) 1 nM-os koncentrációban a Kv1.3 csatornák mintegy 50\%-át gátolta, míg a Kv1.2 csatornákon még 100 nM-os koncentrációban sem volt mérhető hatása (29. ábra).
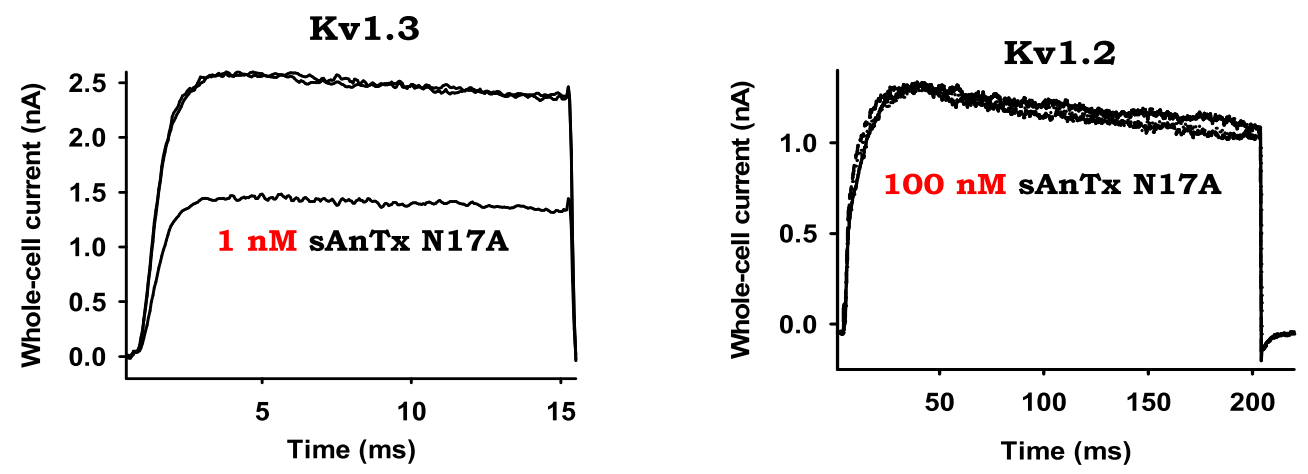

29. ábra: A leghatásosabbnak bizonyult AnTx F32T N17A elektrofiziológiai tulajdonságai

A továbbiakban az előállított mutáns toxinok biológiai vizsgálata a cél, hiszen a tripla meg a többszörös mutánsok remélhetőleg mind affinitásban, mind szelektivitásban felülmúlják a natív toxint és a potenciális terápiás felhasználás lehetőségét kínálják.

\subsubsection{Tc 32 skorpió toxin izomerek előállítása}

A Tc32 peptid toxin a Brazíliában honos Tityus cambridgei skorpióból izolált 35 aminosavból álló toxin, melyet 3 diszulfid híd stabilizál. A rendkívüli felépítésének köszönhetően, a skorpió toxinok $\alpha$-KTx 18.1 altípusának egyetlen képviselője és kísérletekben bizonyítottan szelektíven blokkolja a humán T limfociták Kv1.3 csatornáit a Shaker B típussal szemben. Összehasonlítva az eddig ismert peptid toxinokkal, szekvenciájában két meglepő különbség is szembeötlik: hiányzik a pozitívan töltött aminosav a referenciának számító Charybdotoxin 27-es pozícióban levő Lys-jéhez képest, valamint a szekvencia egyáltalán nem tartalmaz aromás aminosavat. A Tc32 jellemzésének legmeglepőbb eredménye talán, hogy nem tartalmazza a $\mathrm{Kv}$ csatornák blokkolásának előfeltételeként tartott „eszenciális diád”-ot. A molekula 3D modellezése arra világított rá, hogy a pozitív töltésü lizin helyén ebben a toxinban a hidrofil S24 található, valamint a hidrofób aminosav helyén a pozitív töltésű K34 van [95]. 

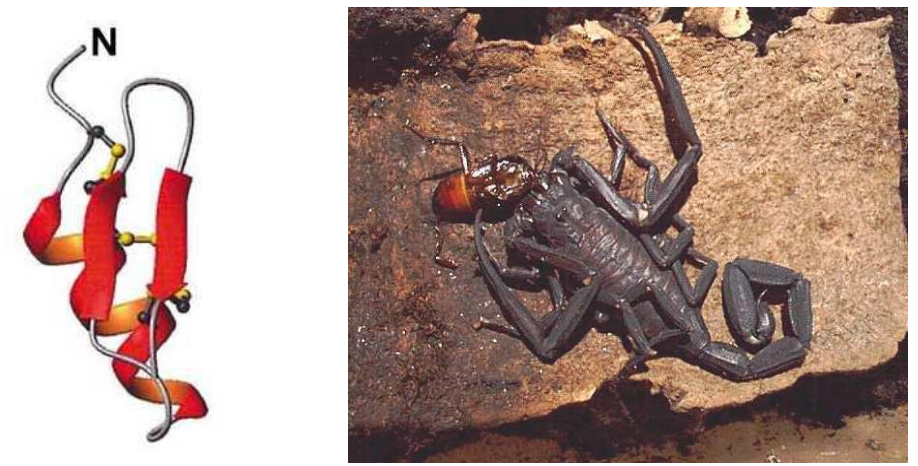

30. ábra: A Tc32 szalagdiagramja (bal) és a Tityus cambridgei skorpió, amelyből izolálták a toxint (jobb)

\subsubsection{1. „Oxidatív folding” kísérletek}

A lineáris Tc32 (kód: TGKA) peptid szintézisére Boc-Ala-PAM hordozót alkalmaztam manuális szilárd fázisú peptidszintézis módszerével Boc/Bzl-stratégiával. A felhasznált aminosavak mindegyike hidrogén-fluoridra érzékeny oldallánc védőcsoporttal rendelkezett. Ennek megfelelően a ciszteinek oldallánca 4-metilbenzil csoporttal volt védve. A kapcsolások során 3-3 ekv. mennyiségben használtam a Boc-aminosav származékokat, a DCC-t és HOBt-t. A peptidet a gyantáról folyékony hidrogén-fluoriddal hasítottam le, gyökfogóként anizolt, dimetil-szulfidot, $p$-krezolt és DTT-t használtam.

13. táblázat: A lineáris és ciklizált Tc32 szekvenciái és tömegspektrometriai adatai

\begin{tabular}{|c|c|c|}
\hline Kód & Szekvencia & M számolt \\
\hline TGKA & TGPQTTCQAAMCEAGCKGLGKSMESCQGDTCKCKA-OH & 3528.0 \\
\hline Tc32 & TGPQTTCCQAAMCCEAGCKGLGKSMESCCQGDTCKCKA-OH & 3522.0 \\
\hline
\end{tabular}

A ciklizálási kísérletekhez a nyers lineáris peptid kis részleteit használtam. Az oxidációs reakciók során a következő reakció paramétereket változtattam: a peptidkoncentrációt: $0.5 \mathrm{mg} / \mathrm{ml}$ vagy $1 \mathrm{mg} / \mathrm{ml}$; a reakcióközeget: víz, ecetsav oldat $(\mathrm{pH}$ 2.7), ammónium-acetát puffer ( $\mathrm{pH} 6.5$, valamint $\mathrm{pH} 7.5)$, glikokoll- $\mathrm{NaOH}$ puffer ( $\mathrm{pH} 8.7$, 9.5, 10), valamint Tris-HCl puffer (pH 8.4); az oxidálószert: levegő, jód, DMSO, redox puffer (cisztein/cisztin), Clear-ox ${ }^{\mathrm{TM}}$ gyanta, valamint denaturáns hozzáadásával (8 $\mathrm{mol} / \mathrm{dm}^{3}$ guanidin $\cdot \mathrm{HCl}$ ) is próbálkoztam. A reakcióelegyből 5, majd 30 percenként mintát vettem, ezt esetenként 10 (v/v\%)-os ecetsavval savanyítottam és analitikai RP-HPLC-re injektáltam. Az oszlopról eluálódó csúcsokat ESI-MS-el ellenőriztem. 

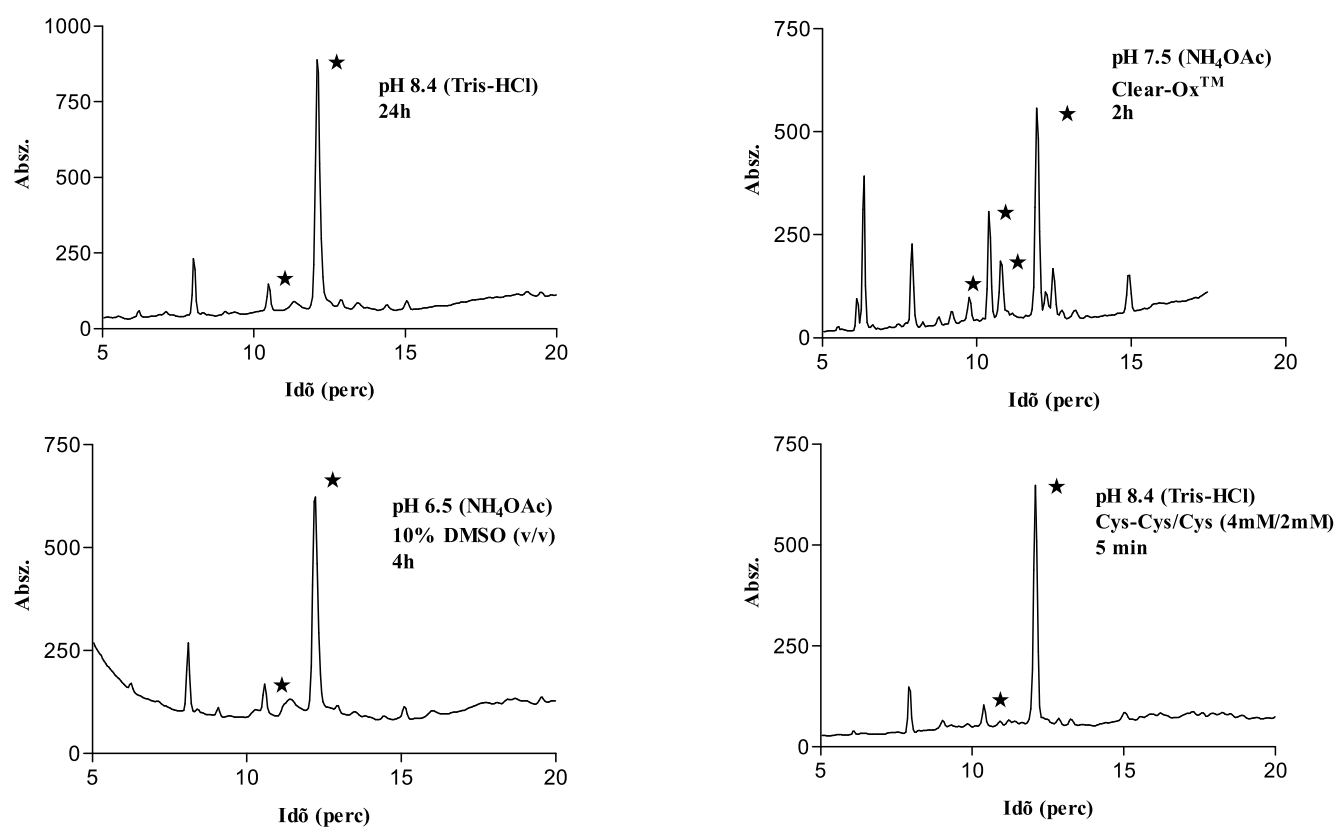

31. ábra: Néhány ciklizálási kísérlet kromatogramja ( ${ }^{*}$ : ciklizált izomer)

A kísérletek során minden esetben egy többségi izomer jelent meg (31. ábra), ennek izolálása megtörtént (kód: Tc32 I). Analitikai jellemzését kromatográfiásan és tömegspektrometriásan végeztem (14. táblázat), azonban biológia mérések igazolták, hogy nem a megfelelő regioszelektivitású izomer keletkezett. A Clear-ox ${ }^{\mathrm{TM}}$ gyantával történő oxidáció során izolálható mennyiségben megjelenik egy második izomer is (kód: Tc32 II), azonban, mint biológiai mérésekből kiderült, ez sem azonos a natív toxinnal.

Tehát a natív Tc32 előállítása „oxidatív folding”-gal nem volt sikeres, az oxidáció regioszelektivitásának növelése szükséges.

14. táblázat: Az izolált Tc32 izomerek analitikai jellemzői

\begin{tabular}{|c|c|c|}
\hline Kód & $\mathbf{t}_{\mathbf{R}}{ }^{*}$ (perc) & $\left.\mathbf{M}_{\text {mért }^{\dagger}}{ }^{\dagger}(\mathbf{M}+\mathbf{H}]^{+}\right)$ \\
\hline Tc32 I & 10.87 & 3523 \\
\hline Tc32 II & 7.56 & 3523 \\
\hline Tc32 III & 7.82 & 3523 \\
\hline Tc32 IV & 9.90 & 3523 \\
\hline Tc32 V & 8.22 & 3523 \\
\hline Tc 32 VI & 9.70 & 45 \\
\hline
\end{tabular}

*: Retenciós idő meghatározása Agilent 1200 HPLC rendszeren (oszlop: Phenomenex Jupiter $4 \mu \mathrm{m}$ Proteo

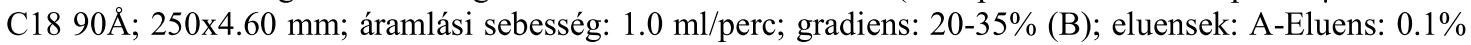
TFA/víz; B-Eluens: $80 \%$ acetonitri1/ $20 \%$ víz/0.1\% TFA)

${ }^{\dagger}:$ MS (ESI ${ }^{+}$): $m / z$; monoizotópos molekulatömeg meghatározása Finnigan TSQ 7000 ESI-MS-en. 


\subsubsection{Konvergens szintézis kísérletek}

A konvergens szintézis ötvözi a regioszelektív cisztein párosítás módszerét az „oxidatív folding”-gal, előnye, hogy nem igényel mindegyik cisztein párnak szelektív védőcsoportot. $\mathrm{A}$ Tc32 esetében a hat cisztein közül egy cisztein párt a natív izomerből rendre szelektív védőcsoporttal láttam el, összezártam az első diszulfid hidat és ezután a többi négy szabad tiolt az „oxidatív folding” módszerével oxidáltam. A Cys-ek oldalláncának védelmére Trt és Acm védőcsoportokat használtam. Az általam szintetizált védett lineáris Tc32 szekvenciákat a 15. táblázat foglalja össze.

15 táblázat: A szintetizált védett lineáris Tc32 szekvenciák

\begin{tabular}{|c|c|}
\hline Kód & Szekvencia \\
\hline TGKA-C $^{\mathbf{1 2 , 1 6 , 3 1 , 3 3}}$-Acm & TGPQTTCQAAMC(Acm)EAGC(Acm)KGLGKSMESCQGDTC(Acm)KC(Acm)KA-OH \\
\hline TGKA-C $^{\mathbf{7 , 1 6 , 2 6 , 3 3}}$-Acm & TGPQTTC(Acm)QAAMCEAGC(Acm)KGLGKSMESC(Acm)QGDTCKC(Acm)KA-OH \\
\hline TGKA-C $^{\mathbf{7 , 1 2 , 2 6 , 3 1}}$-Acm & TGPQTTC(Acm)QAAMC(Acm)EAGCKGLGKSMESC(Acm)QGDTC(Acm)KCKA-OH \\
\hline
\end{tabular}

A TGKA-C ${ }^{12,16,31,33}$-Acm és TGKA-C $\mathrm{C}^{7,16,26,33}$-Acm peptideket Boc-Ala-PAM hordozón állítottam elő manuális Boc-kémiával. A peptidek kódjában jelölt aminosavakon kívül a felhasznált aminosav származékok mindegyike hidrogén-fluoridra hasadó oldallánc védőcsoporttal rendelkezett. A kapcsoláshoz 3-3 ekv. Boc aminosav származékot, DCC-t és HOBt-t használtam. A kész peptideket a gyantáról folyékony HFdal hasítottam le, gyökfogóként anizolt, dimetil-szulfidot, $p$-krezolt és DTT-t használtam.

A TGKA-C $\mathrm{C}^{7,12,26,31}$-Acm szintézise Fmoc-Ala-Wang polimeren történt CEM mikrohullámú peptidszintetizátorral. A felhasznált Fmoc-aminosav származékok, kivéve a $\mathrm{C}^{7,12,26,31}$ aminosavait, TFA-ra érzékenyek oldallánc védőcsoportokat tartalmaztak. Az aminosavak kapcsolásához 4-4 ekv. HBTU és HOBt elegyét használtam DIEA jelenlétében. A kész peptidet a gyantáról TFA/víz/DTT/TIS 83:10:5:2 (v/v/m/v) arányú elegyével hasítottam le.

Az optimalizált CEM protokollt a 27. táblázat (ld. 5.5.2 fejezet) foglalja össze. A Cys kapcsolásához a gyártó által ajánlott $50^{\circ} \mathrm{C}$-os aktiválást használtam. A teljesebb kapcsolások biztosítására végig dupla kapcsolásokat alkalmaztam.

Hasítás után a szabad tiol csoportok oxidálására próbareakciókat végeztem a nyers lineáris peptid kis részleteivel. A Clear-ox ${ }^{\mathrm{TM}}$ gyanta használata újból előnyösebbnek 
bizonyult a levegőn történő oxidációhoz képest, ugyanis 4 óra alatt a lineáris peptid teljes átalakulása elérhető. Az Acm csoport eltávolítása és a keletkező szabad tiol csoportok összezárása egy lépésben történik. A ciklizáláshoz jódot használtam 10 ekv. menyiségben (2.5 ekv. mindegyik Cys-re számolva) különböző közegekben: ecetsav/víz 4:1 (v/v) és metanol/víz 8:2 (v/v) arányú elegyében. A reakció metanol/víz elegyében gyorsabban lejátszódott, ezért ezt a módszert választottam a továbbiakban. Az oxidációban használt jód feleslege egyszerü diklórmetánba vagy kloroformba történő átrázással eltávolítható.

$\mathrm{Az}$ optimálizált módszerekkel a ciklizálást megismételtem nagyobb mennyiségben mindegyik lineáris peptiddel. Mindhárom ciklizálás más és más többségi izomert eredményezett, ezek izolálása megtörtént (lásd 14. táblázat: Tc32 III, Tc32 IV, Tc32 V), azonban biológiai mérésekben ugyanúgy inaktívnak bizonyultak, mint az első két izolált termék.

3.3.3.3. Tc32 izomerek előállítása a lépésenkénti regioszelektív cisztein párosítások módszerével

Három diszulfid híd kialakítása ezzel a módszerrel meglehetősen nagy kémiai kontrollt igényel, a módszer másik nagy hátránya, hogy a Cys védőcsoportok nagy száma ellenére kevés teljesíti az ortogonalitás követelményét az általánosan alkalmazott peptid szintézis stratégiák mellett. A Fmoc-kémia ebből a szempontból több lehetőséget biztosít. A ciklizált termék kinyerésének végső hatásfoka minden esetben rendkívül alacsony.

A Tc32 natív izomerjének szintézisére választott ortogonális Cys védőcsoportok: $\mathrm{StBu}$, Trt és Acm.

16. táblázat: A szelektíven védett lineáris Tc32 (kód: TGKA-C $\left.C^{7,26}-A c m, C^{16,33}-\mathrm{S} t \mathrm{Bu}\right)$ szekvenciája

\begin{tabular}{|c|c|}
\hline Kód & Szekvencia \\
\hline $\begin{array}{c}\text { TGKA-C } \mathrm{C}^{7,26}-\mathrm{Acm}, \\
\mathrm{C}^{16,33}-\mathrm{S} t \mathrm{Bu}\end{array}$ & TGPQTTC(Acm)QAAMCEAGC(StBu)KGLGKSMESC(Acm)QGDTCKC(StBu)KA-OH \\
\hline
\end{tabular}

A TGKA-C $\mathrm{C}^{7,26}-\mathrm{Acm}, \mathrm{C}^{16,33}-\mathrm{S} t \mathrm{Bu}$ peptid szintézise Wang polimeren történt manuális szilárd fázisú Fmoc/tBu-stratégiával. A felhasznált aminosavak, a $C^{7,26}-A c m$ és $\mathrm{C}^{16,33}$-St $\mathrm{Bu}$ aminosavakat kivéve, TFA-ra érzékeny oldallánc védőcsoportokkal voltak ellátva. A kapcsoláshoz 3-3 ekv. Fmoc-aminosav származékot, DCC-t és HOBt-t használtam. 
Az eredeti elgondolás szerint az $\mathrm{S} t \mathrm{Bu}$ védőcsoport hasítása és a felszabaduló tiol csoportok kapcsolása lett volna az első lépés. Ezt még a szilárd hordozón szerettem volna kivitelezni, de a védőcsoport lehasítása nem sikerült. Az StBu védőcsoport lehasítására az irodalomban közölt módszerek többségét kipróbáltam [20 (v/v\%) $\beta$-merkaptoetanol 0.1 M NMM/DMF oldatában, $60{ }^{\circ} \mathrm{C}$-ra melegítve, stb]. Az $\mathrm{StBu}$ védőcsoport eltávolítási sikertelenségét gyantán ugyancsak irodalmi adatok támasztják alá, azzal a magyarázattal, hogy a védőcsoport hasítási hatékonysága nagyon függ a peptid hosszától és aminosavszekvenciájától. Ezért a következőkben lehasítottam a peptidet a gyantáról TFA/víz/DTT 92:5:3 (v/v/m) elegyével, szabaddá téve az eredetileg Trt-el védett 12-es és 31-es Cys oldalláncokat.

A szabad tiol csoportok összezárására próbareakciókat végeztem a nyers lineáris peptid kis részleteivel. A reakcióelegyből 5, 10 majd 30 percenként mintát vettem, esetenként $10(\mathrm{v} / \mathrm{v} \%)$-os ecetsavval savanyítottam és analitikai HPLC-re injektáltam, az eluálódó csúcsokat ESI-MS-el ellenőriztem.

A peptidet $0.5 \mathrm{mg} / \mathrm{ml}$ koncentrációban használtam a szabad tiolok jobb hozzáférhetősége miatt. A kísérletek során különböző pH-jú közegeket, oxidálószerként a levegő oxigénjét, illetve Clear-ox ${ }^{\mathrm{TM}}$ gyantát használtam. A keletkező termékek tömegspektrometriás azonosítása alapján megállapítottam, hogy bázikus közegben nem stabil a terc-butil-szulfenil csoport, hiszen már az első 5-10 percben pH 7.5-10 között teljes mértékben lehasad, ezért az első diszulfid híd összezárását savas pH-jú ammóniumacetát pufferben $\left(\mathrm{pH}\right.$ 6.5) végeztem Clear-ox ${ }^{\mathrm{TM}}$ gyantával. A következő védőcsoport eltávolításhoz az így összezárt terméket használtam. Az $\mathrm{St} \mathrm{Bu}$ csoport hasítása és a keletkező tiol csoportok összezárása a leghatékonyabban enyhén bázikus ammóniumacetát pufferben (pH 7.5) 5 ekv. Cys jelenlétében valósult meg. Az Acm csoport hasítása előtt a már két diszulfid hidat tartalmazó peptidet megtisztítottam szemipreparatív HPLCn. A harmadik diszulfid híd kialakítására az előzőekben már kipróbált módszert alkalmaztam: az Acm eltávolítását jóddal végeztem metanol/víz 8:2 (v/v) elegyében. Az oxidálószer feleslegét diklórmetánba történő átrázással távolítottam el. Az oxidáció termékét kromatográfiásan tisztítottam és analitikai HPLC és ESI-MS segítségével jellemeztem. 
A regioszelektív cisztein párosítások módszerével izolált főtermék a legelső izomerrel (Tc32 I) azonos. Ezzel a módszerrel izoláltam egy hatodik izomert is (Tc32 VI), azonban ez is inaktívnak bizonyult biológiai vizsgálatokban. Az alkalmazott módszer során izomerek megjelenését az okozhatta, hogy a 2. lépésben oxidálószerként a szabad tiol csoporttal rendelkező Cys-t használtam, ami a diszulfid hidak keveredését okozhatta. A lehetséges ciklizált izomerek száma ennél a lépésnél 3, ebből izoláltunk kettőt, de fennáll a lehetősége annak, hogy a natív izomert nem sikerült izolálni.

Az eredmények alapján elmondható, hogy az $\mathrm{S} t \mathrm{Bu}$ védőcsoport nem teljesítette az ortogonalitás feltételeit. A kísérletek alapján - a különböző szintézisek főterméke mindig egyazon izomert eredményezte, mely nem azonos a natív izomerrel - felmerül a diszulfid hidak helyének meghatározási pontossága. A továbbiakban tervezzük újabb ortogonális védőcsoport kombináció kipróbálását a regioszelektív cisztein párosítások módszerével a fenti feltételezésünk igazolására.

\subsection{Allergiás reakció kialakulásának gátlása C3a-eredetű C3a9 dimerekkel}

Ismert, hogy az allergének (például házi poratkából, virágporból, különböző ételekből származó fehérjék) főként IgE típusú ellenanyagok közvetítésével váltják ki a túlérzékenységi reakciót, melyben a nagy affinitású IgE-receptorok (az FceRI) keresztkötése döntő fontosságú. A folyamat mechanizmusát vizsgálva bebizonyosodott, hogy a C3a peptid, illetve annak különböző szintetikusan előállított származékai oly módon gátolják az allergiás reakció kialakulását, hogy a hízósejt aktivációját közvetítő IgE-kötő receptorokhoz kapcsolódva megakadályozzák e sejtmembrán molekulák aggregációját, illetve az ennek hatására meginduló aktivációs folyamatokat.

Munkacsoportunk az ELTE Immunológiai Tanszékével együttmüködésben már korábban feltérképezte, hogy a $\mathrm{C} 3 \mathrm{a}$ molekulának mely része felelős a gátlásért. $\mathrm{Az}$ azonosított aminosav-szekvencia alapján a C3a7 (CCNYITELR), mely a C3a természetes szekvenciája, egy módosított származékát a C3a9-et (DCCNYITR) jelölte ki aktív centrumnak [65].

Biológiai vizsgálatokban a C3a9 szekvencia a kereskedelmi forgalomban kapható antihisztaminokkal összemérhető gátlást mutatott (32. ábra). A felhasznált anyagok: Dexamethason, Nátrium kromoglikát és Hydrokortizon voltak 


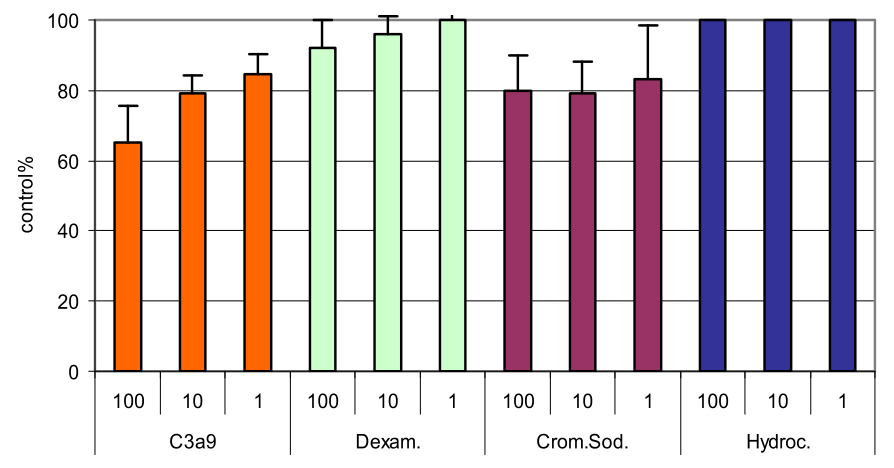

$\mu \mathrm{g}$

32. ábra: Kereskedelmi forgalomban kapható anti-allergikumok hatása humán bazofil sejtek aktivációjára

A gátló hatásban aktívnak tartott C3a9 szekvencia feltételezhetően intermolekuláris diszulfid hidakkal stabilizált formája a felelős. Ennek bizonyítására a szimmetrikus dimer szekvenciát állítottam elő.

A C3a9 szekvenciájában két szabad tiol csoport is található, így dimer képzésre többféleképpen is lehetőség nyílik. A tiol csoportok véletlenszerü összezárásával vegyes dimerek, egy kémiailag irányított folyamatban a kívánt izomerek keletkezhetnek.

A C3a9 szimmetrikus dimer szintézisére regioszelektív cisztein párosításokat alkalmaztam (33. ábra).

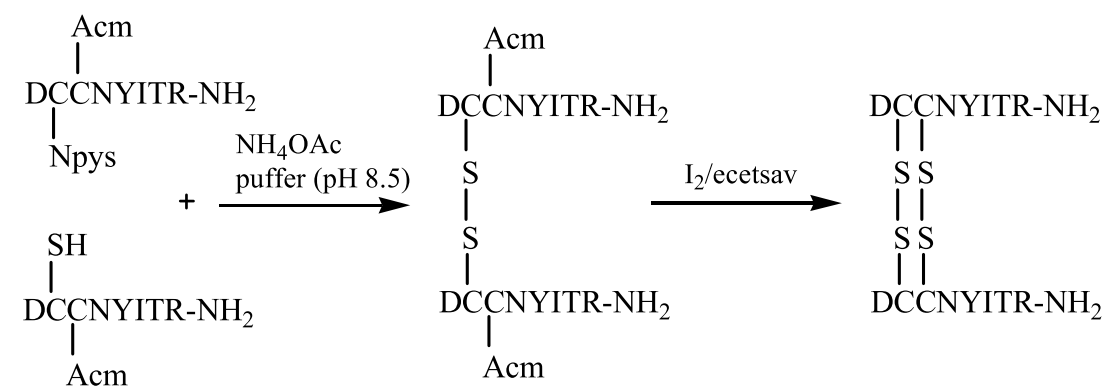

33. ábra: A C3a9 szimmetrikus dimer előállítása

A peptidek előállítását manuális szilárd fázisú peptidszintézis módszerével valósítottam meg, a Boc/Bzl-stratégiát alkalmazva MBHA hordozón. A felhasznált aminosavak oldalláncai hidrogén-fluoridra érzékeny védőcsoportok voltak, kivéve az Alánc $C^{2}$-Npys, illetve $C^{3}-A c m$, valamint a $B$-lánc $C^{3}$-Acm aminosavát, mely aminosavak védőcsoportjainak lépésenkénti eltávolítása és a keletkező szabad tiol csoportok összeoxidálása biztosította a szelektív intermolekuláris diszulfid-hidak kialakítását. 
17. táblázat: A szintetizált A- és B-lánc, valamint a C3a9 szimmetrikus dimer szekvenciái és analitikai paraméterei

\begin{tabular}{|c|c|c|c|c|c|}
\hline Kód & Szekvencia & $\begin{array}{c}\text { Analitikai } \\
\text { HPLC } \\
\text { gradiens }\end{array}$ & $\begin{array}{c}\mathbf{t}_{\mathbf{R}}{ }^{*} \\
(\text { perc) }\end{array}$ & $\mathbf{M}_{\text {számított }}$ & $\begin{array}{c}\mathbf{M}_{\text {mért }}^{\dagger} \\
\left([\mathbf{M}+\mathbf{H}]^{+}\right)\end{array}$ \\
\hline A-lánc & $\begin{array}{c}\text { DC(Npys)C(Acm)NYITR- } \\
\mathrm{NH}_{2}\end{array}$ & $\begin{array}{c}5-80(\% \mathrm{~B}) \\
25 \text { perc }\end{array}$ & 12.68 & 1211.3 & 1212 \\
\hline B-lánc & DCC(Acm)NYITR-NH ${ }_{2}$ & $\begin{array}{c}5-80(\% \mathrm{~B}) \\
25 \text { perc }\end{array}$ & 9.82 & 1057.2 & 1058 \\
\hline $\begin{array}{c}\text { C3a9 szimm. } \\
\text { dimer }\left[(\mathrm{DCTR})_{2}\right]\end{array}$ & $\left(\text { DCCNYITR-NH }{ }_{2}\right)_{2}$ & $\begin{array}{c}19-34(\% \mathrm{~B}) \\
15 \text { perc }\end{array}$ & 8.02 & 1968.2 & 1969 \\
\hline
\end{tabular}

*: Retenciós idő meghatározása Agilent 1100 HPLC rendszeren (oszlop: Phenomenex Luna $5 \mu \mathrm{m}$ C18(2)

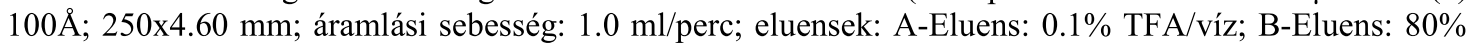
acetonitril $/ 20 \%$ víz/0.1\% TFA)

${ }^{\dagger}$ : MS (ESI ${ }^{+}$): $m / z$; monoizotópos molekulatömeg meghatározása Finnigan TSQ 7000 ESI-MS-en.

A védett peptidek gyantáról való hasítása után az első lépésben ammónium-acetát pufferben ( $\mathrm{pH} 8.5$ ) tiolízissel zártam össze a két láncot a $\mathrm{C}^{2}$-aminosavakon keresztül, majd a keletkező nyers terméket tisztítás nélkül használtam fel a következő lépésben. A reakcióelegyből 15 percenként mintát vettem, 10 (v/v\%)-os ecetsavval savanyítottam és analitikai HPLC-re injektáltam, majd az eluálódó csúcsokat ESI-MS-el ellenőriztem. A reakció 1 óra alatt játszódott le teljes mértékben. A két lánc $\mathrm{C}^{3}-\mathrm{Acm}$ csoportjának eltávolítása és a keletkező szabad tiol csoportok összekapcsolása egy lépésben történt 50 (v/v\%)-os ecetsav vizes oldatában jód jelenlétében. Ennél a lépésnél kulcsfontosságú volt a peptidkoncentráció mértéke, hiszen mellékreakció során nem kívánt tetramerek vagy egyéb oligomerek is keletkezhetnek. Ennek elkerülésére $0.5 \mathrm{mg} / \mathrm{ml}$ koncentrációban alkalmaztam a peptidet. A jodolízis 2 óra alatt játszódott le teljes mértékben. A fölösleges jódot diklórmetánnal távolítottam el a reakcióelegyből. A nyers terméket szemipreparatív RP-HPLC-n tisztítottam.
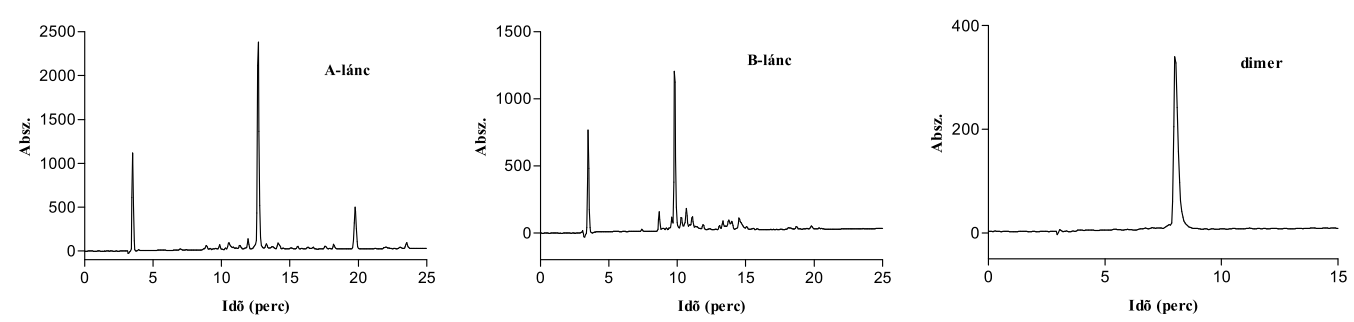

34. ábra: A felhasznált nyers A- és B-lánc, valamint a tisztított (DCTR) $)_{2}$ szimmetrikus dimer kromatogramja 
A kiindulási peptideket, valamint a keletkező dimer jellemzését analitikai HPLC$\mathrm{n}$ mért retenciós idejük és molekulatömegük alapján végeztem (17. táblázat, 34. ábra).

Az előállított C3a9 dimer tesztelése biológiai rendszerekben folyamatban van.

\subsection{Gab1 adapter fehérje eredetü foszfopeptidek előállítása és vizsgálata a B- sejtek jelátviteli folyamataiban}

A Gab családba tartozó adapter fehérjék a jelátadás során mind pozitív, mind negatív szerepet betölthetnek. Ez függ a sejt- illetve a jelátadást elindító receptor típusától, és az abban kifejezésre jutott Gab izoformától. A szabályozó funkció előjelét befolyásolhatja a Gab-hoz kötődő molekulák foszforilációs állapotának az adott jel hatására bekövetkező változása, és a Gab sejten belüli lokalizációja. Mindezek a tényezők meghatározók abból a szempontból, hogy a Gab adapter fehérje a megfelelő időben a megfelelő helyen legyen a sejtben, és megszabják a Gab által összetartott molekula-komplex összetételét is.

Az irodalmi adatok szerint a BCR-en keresztül kiváltott tirozin kináz aktiválódás következtében a Gab1 foszforilálódik és képes közvetlen kölcsönhatásba lépni az SHP-2, PI3-K, PLCgamma és Shc fehérjékkel.

Annak tisztázására, hogy az egyes foszforilált Gab1 motívumok hogyan befolyásolják az SHP-2 foszfatáz aktivitását, először a Gab1 foszforilált motívumainak megfelelö, szintetikus foszfopeptidek SHP-2 aktiváló hatását vizsgáltuk. A foszfatáz aktivitás mérésére avidinnel fedett ELISA lemezekre mérik az előzetesen SHP-2-vel kezelt, biotinilált foszfopeptideket, majd a foszfotirozintartalmat specifikus ellenanyag segítségével mérik vissza.

A továbbiakban szerettük volna vizsgálni, hogy a GDLDpe szekvencia milyen fehérjékkel asszociálódik BL41 Burkitt limfóma sejtek lizátumában. Annak a kérdésnek a tisztázására, hogy ezek az YLDL motívumot tartalmazó peptidek módosíthatják-e ténylegesen a sejten belüli jelátviteli folyamatokat, milyen szerepet játszhatnak a natív molekulában, a sejtmembránon átjutó foszfopeptideket szintetizáltam és vizsgáltuk ezek hatását a sejten belüli kalciumimmobilizációra. 
3.5.1. Gab1 eredetű foszfopeptidek és módosított származékainak előállítása

Sármay és munkatársai már korábban kimutatták, hogy a Gab1 eredetü GDLDpe (621-633) peptid nagy affinitással kötődik az SHP-2 tirozin foszfatázhoz [96, 97]. A továbbiakban azt a legrövidebb hatékony szekvenciát szerettük volna megtalálni a GDLDpe peptid rövidítésével, amely szükebb hatásspektrummal rendelkezik, tehát segítségével egy szelektívebb hatást érhetünk el, és ezáltal pontosabban feltérképezhetjük a Gab1-Erk ill. Gab1-PI3-K jelpályák szabályozását B-sejtekben.

Az általam szintetizált Gab 1 adapter fehérje eredetű foszfopeptidek listáját a 18. táblázat tartalmazza.

18. táblázat: A szintetizált Gab1 eredetü foszfopeptidek szekvenciái és tömegspektrometriai adatai

\begin{tabular}{|c|c|c|c|}
\hline Kód & Szekvencia & $\mathbf{M}_{\text {számított }}$ & $\begin{array}{c}\mathbf{M}_{\text {mért }}^{\dagger} \\
\left([\mathbf{M}+\mathbf{H}]^{+}\right)\end{array}$ \\
\hline GDLDpe & GDKQVEY $(p)$ LDLDLD-NH ${ }_{2}$ & 1601.6 & 1602 \\
\hline QVDLpe & $\mathrm{QVEY}(p) \mathrm{LDL} \mathrm{NH}_{2}$ & 957.9 & 958 \\
\hline EYDLpe & $\mathrm{EY}(p) \mathrm{LDL}^{-\mathrm{NH}_{2}}$ & 958.9 & 959 \\
\hline DKYLpe & $\operatorname{DKQVEY}(p) \mathrm{L}-\mathrm{NH}_{2}$ & 973.0 & 974 \\
\hline VELDpe & VEY $(p) \mathrm{LDLD}-\mathrm{NH}_{2}$ & 944.9 & 945 \\
\hline QVLDpe & QVEY $(p)$ LDLD-NH $_{2}$ & 1073.0 & 1074 \\
\hline KQLDpe & KQVEY $(p)$ LDLD-NH $_{2}$ & 1201.0 & 1202 \\
\hline DKLDpe & DKQVEY $(p)$ LDLD-NH ${ }_{2}$ & 1316.3 & 1317 \\
\hline
\end{tabular}

: MS (ESI ${ }^{+}$: $m / z$; monoizotópos molekulatömeg meghatározása Finnigan TSQ 7000 ESI-MS-en.

A Gab1 eredetü foszfopeptideket TentaGel R RAM polimeren állítottam elő szilárd fázisú peptidszintézissel, Fmoc/tBu-stratégiával. A beépített aminosavak oldallánc védőcsoportja TFA-ra érzékeny volt egyetlen kivétellel, a trifunkciós aminosavak közül a tirozin oldallánc védőcsoport nélkül építettem be. A Fmoc védőcsoport eltávolítását piperidin/dimetilformamid $20(\mathrm{v} / \mathrm{v} \%)$-os oldatával végeztem, ezt követte a peptid-gyanta mosása (DMF, metanol). A kapcsoláshoz 3-3 ekv. Fmoc-aminosav származékot, DCC-t és HOBt-t használtam. A kapcsolási reakció sikerességét ninhidrin teszttel ellenőriztem.

A foszfotirozin tartalmú peptidek szintézisére az úgynevezett „online” foszforiláció módszerét alkalmaztam, mert ez a módszer sikeresen ötvözi a „synthon” és a globális módszer előnyeit. A tirozint oldallánc védőcsoport nélkül építettem be, majd ezt követte a hordozóhoz kapcsolt peptid foszforilációja. A tirozin szabad fenolos hidroxil csoportját első lépésben 15-20 ekv. di-terc-butil- $N, N$-dietilfoszforamidittel foszfitiláltam, majd egy következő lépésben a III vegyértékü foszfort oxidáltam 14 (v/v\%)-os terc-butilhidroperoxiddal. A folyamatot a 35. ábra mutatja be. 


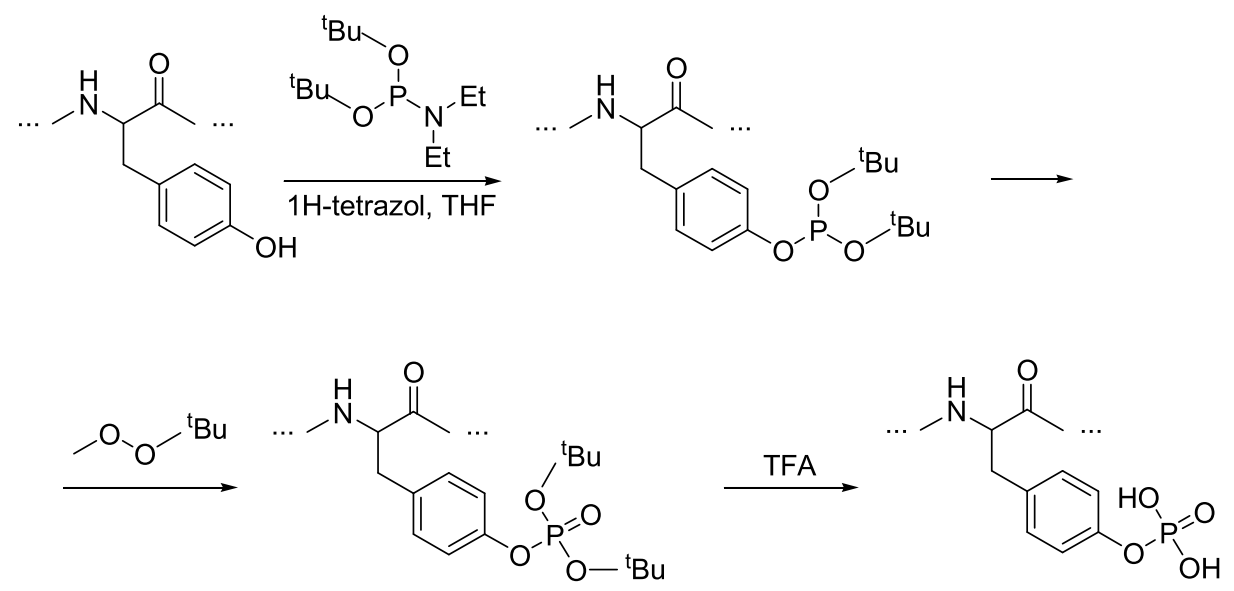

35. ábra: A Tyr „online” foszforilációja

A peptidlánc a tirozin $\mathrm{N}^{\alpha}$-Fmoc védőcsoportjának hasításával építődik tovább. A kész peptideket, a biotinilálásra való tekintettel, szekvencia-függően hasítottam le a gyantáról TFA/víz/DTT 92:5:3 (v/v/m\%) arányú elegyével. Néhány nyers peptidet, a tisztaságtól függően, biotinilálás előtt kromatográfiásan megtisztítottam.

A biológiai kísérletekhez, egyrészt kontrollként, másrészt annak tisztázására, hogy a jelátviteli folyamatokban a Gab1 eredetü foszfopeptidekhez kapcsolódó fehérjék mennyire szekvencia specifikusak, módosított formáit is szintetizáltuk.

Kontroll peptidnek tirozint fenilalaninra cserélt GDFLD, ill. tirozinon nem foszforilált GDLD peptideket állítottam elő. Laboratóriumunkban szintetizálták az irodalmi adatok szerint foszfatázokkal szembeni rezisztenciát okozó, a foszfát csoportban oxigén-kén atom cserét hordozó GDLDsp (GDKQVEY( $s p$ LDLDLD-NH ${ }_{2}$ ) tiofoszfopeptidet is. A QVDLpe peptidet, mint a GDLDpe $N$ - és $C$-terminálisan 3-3 aminosavval rövidített formáját is felhasználtuk ezeknél a vizsgálatoknál.

Az általam szintetizált módosított GDLDpe peptidek szekvenciáit a 19. táblázat illusztrálja.

19. táblázat: A módosított GDLDpe peptidek tömegspektrometriás jellemzése

\begin{tabular}{|c|c|c|c|}
\hline Kód & Szekvencia & $\mathbf{M}_{\text {számított }}$ & $\begin{array}{c}\mathbf{M}_{\text {mért }^{\dagger}} \\
\left(\left[\mathbf{M}+\mathbf{H}^{\dagger}\right)\right.\end{array}$ \\
\hline GDLD & GDKQVEYLDLDLD-NH & 1522 \\
\hline GDFLD & GDKQVEFLDLDLD-NH & 1521.6 & 1506 \\
\hline
\end{tabular}

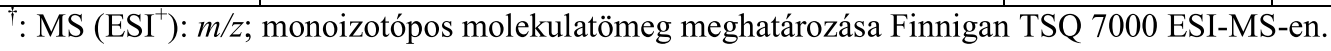


A módosított GDLDpe peptidek szintézise TentaGel R RAM polimeren készült manuális szilárd fázisú Fmoc-kémiával. A szintézisben használt Fmoc-aminosav származékok oldallánca TFA-ra hasítható volt. A kapcsoláshoz DCC-t és HOBt-t használtam 3-3 ekv. mennyiségben. A Fmoc védőcsoport hasítását piperidin/ dimetilformamid 20 (v/v\%)-os oldatával valósítottam meg. A kész peptidek gyantáról való hasítása 95 (v/v\%) TFA-val történt, gyökfogónak 3 (m/v\%) DTT-t használtam. A nyers peptideket tisztítás nélkül reagáltattam a következőkben.

3.5.2. Biotinilált Gab1 eredetű foszfopeptidek és módosított származékainak előállítása és biológiai vizsgálata

Számos biológiai kötődési módszer alapja a peptid - receptor, vagy peptid ellenanyag kötődési vizsgálata. Erre a célra a vizsgálandó peptidet gyakran biotinnal jelölik, a legtöbb esetben egy távolságtartó, hosszabb szénláncot tartalmazó biotinszármazékot alkalmazva, mint pl. a biotinil-e-amino kapronsavat.

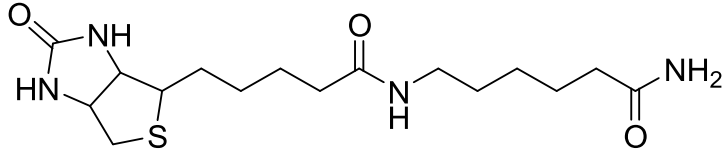

36. ábra: A biotin- $\varepsilon$-amino kapronsav

Peptidek biotinnal való jelölésére az irodalomban számos példát találunk [98]. A biotint általában a szintetizált peptid $N$-terminális aminosavának $\alpha$-aminocsoportjához kapcsolják a peptidkémiában használatos kapcsolóreagensek segítségével. A leggyakrabban használt, kereskedelmi forgalomban kapható aktivált biotin származék a biotinil- $\varepsilon$-amino-kapronsav $N$-hidroxiszukcinimid észtere.

A biotinnal jelölt Gab1 eredetű foszfopeptidek, valamint származékai listáját a 20. táblázat foglalja össze.

A biotinilálást azoknál a peptideknél, amelyek nem tartalmaznak szekvenciájukban Lys-t oldatban végeztem. A reakciókhoz általában a nyers peptideket használtam, mert analitikai RP-HPLC-n és ESI-MS-n való jellemzésük általában $85 \%$ fölötti tisztaságot mutatott. A peptideket kis térfogat dimetilformamidban oldottam, pár csepp víz hozzáadása után az oldat pH-ját 8-9-re állítottam DIEA-val és 1.5-2 ekv. biotinil-e-amino-kapronsav $N$-hidroxiszukcinimid észterrel kapcsoltam. A reakciót 
kromatográfiásan követtem. A teljes átalakulás után az oldatot savanyítottam és szemipreparatív HPLC-re injektáltam a reakcióelegyet és megtisztítottam.

A biotinilálást azoknál a szekvenciáknál amelyek Lys-t is tartalmaznak szilárd fázison végeztem. Ebben az esetben a gyantára kötött peptid szabad $N$-terminálisához kapcsoltam a biotin-ع-kapronsavat hasonlóan egy aminosav kapcsoláshoz, 3-3 ekv. DCC és HOBt jelenlétében. A termék gyantáról való hasítása nem igényel speciális körülményeket. A nyers termékeket szemipreparatív HPLC-n tisztítottam.

A kész termékeket minden esetben retenciós idejük és molekulatömegük alapján jellemeztem (20. táblázat).

20. táblázat: Biotinilált Gab1 eredetű foszfopeptidek és módosított származékainak analitikai paraméterei

\begin{tabular}{|c|c|c|c|c|c|}
\hline Kód & Szekvencia & $\begin{array}{c}\text { Anal. } \\
\text { HPLC } \\
\text { grad. } \\
(\% \mathrm{~B})\end{array}$ & $\begin{array}{c}\mathbf{t}_{\mathrm{R}}{ }^{*} \\
\text { (perc) }\end{array}$ & $\mathbf{M}_{\text {számított }}$ & $\underset{\left([\mathbf{M}+\mathbf{H}]^{+}\right)}{\mathbf{M}_{\text {mért }^{\dagger}}}$ \\
\hline Biot-GDLD & Biotinil-NH- $\left(\mathrm{CH}_{2}\right)_{5}$-CO-GDKQVEYLDLDLD-NH ${ }_{2}$ & $28-43$ & 9.41 & 1861.1 & 1862 \\
\hline Biot-GDFLD & Biotinil-NH- $\left(\mathrm{CH}_{2}\right)_{5}$-CO-GDKQVEFLDLDLD-NH ${ }_{2}$ & $38-53$ & 7.24 & 1845.1 & 1846 \\
\hline Biot-QVDLpe & Biotinil-NH- $\left(\mathrm{CH}_{2}\right)_{5}-\mathrm{CO}-\mathrm{QVEY}(p) \mathrm{LDL}-\mathrm{NH}_{2}$ & $25-40$ & 7.91 & 1297.4 & 1298 \\
\hline Biot-EYDLpe & Biotinil-NH- $\left(\mathrm{CH}_{2}\right)_{5}$-CO-EY $(p)$ LDL-NH ${ }_{2}$ & $31-46$ & 7.10 & 1298.4 & 1299 \\
\hline Biot-DKYLpe & Biotinil-NH- $\left(\mathrm{CH}_{2}\right)_{5}$-CO-DKQVEY $(p) \mathrm{L}^{-\mathrm{NH}_{2}}$ & $30-50$ & 10.82 & 1312.4 & 1313 \\
\hline Biot-VELDpe & Biotinil-NH- $\left(\mathrm{CH}_{2}\right)_{5}$-CO-VEY $(p)$ LDLD-NH ${ }_{2}$ & $35-50$ & 7.17 & 1284.4 & 1285 \\
\hline Biot-QVLDpe & Biotinil-NH- $\left(\mathrm{CH}_{2}\right)_{5}$-CO-QVEY $(p)$ LDLD-NH ${ }_{2}$ & $30-45$ & 6.65 & 1412.5 & 1413 \\
\hline Biot-KQLDpe & Biotinil-NH- $\left(\mathrm{CH}_{2}\right)_{5}$-CO-KQVEY $(p)$ LDLD-NH ${ }_{2}$ & $29-44$ & 7.38 & 1540.5 & 1541 \\
\hline Biot-DKLDpe & Biotinil-NH- $\left(\mathrm{CH}_{2}\right)_{5}$-CO-DKQVEY $(p)$ LDLD-NH ${ }_{2}$ & $29-44$ & 6.93 & 1655.8 & 1656 \\
\hline
\end{tabular}

*: Retenciós idő meghatározása Agilent 1100 HPLC rendszeren (oszlop: Phenomenex Luna $5 \mu \mathrm{m}$ C18(2) 100Å; 250x4.60 mm; áramlási sebesség: $1.0 \mathrm{ml} /$ perc; eluensek: A-Eluens: 0.1\% TFA/víz; B-Eluens: $80 \%$ acetonitril/20\% víz/ $0.1 \%$ TFA)

${ }^{\dagger}$ : MS (ESI ${ }^{+}$: $m / z$; monoizotópos molekulatömeg meghatározása Finnigan TSQ 7000 ESI-MS-en.

A biotinilált peptidek biológiai vizsgálatát az ELTE Immunológiai Tanszékén végezték. A szekvenciák foszfatáz aktivitás módosító hatását a már említett módon mérték: avidinnel fedett ELISA lemezekre mérik az előzetesen SHP-2-vel kezelt, biotinilált foszfopeptideket, majd a foszfotirozintartalmat specifikus ellenanyag segítségével mérik vissza.

Annak vizsgálatára, hogy ezek a foszfopeptidek még milyen jelátviteli molekulákkal léphetnek kölcsönhatásba, a biotinilált peptideket avidinnel fedett gyöngyökhöz kötik, és a kapcsolódó molekulákat elektroforézist követően Western blot módszerrel mutatják ki. 


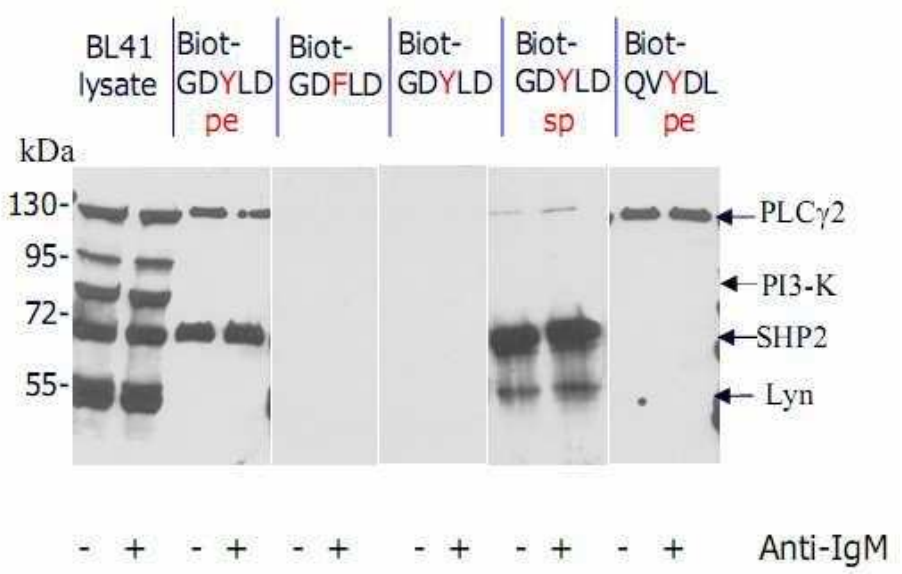

37. ábra: A biotinilált GDLDpe-vel és módosított formáival sejtlizátumban asszociálódó fehérjék azonosítása SDS-PAGE, Western blot analízissel. Kontroll (-) és anti-IgM-mel stimulált (+) BL41 sejtek lizátumát használva.

Az eredeti GDLDpe és módosított GDLDsp változata is erőteljesen asszociálódik az SHP-2 tirozin foszfatázzal, míg a PLC-gamma jóval kisebb mértékü kötődést mutat a GDLDsp peptidhez, mint az eredeti szekvenciához. A kontrollként használt GDLD ill. a GDFLD fenilalanint tartalmazó peptidhez - a vártnak megfelelően - nem kötődtek fehérjék a sejtlizátumból, igazolva, hogy ez a kölcsönhatás foszfotirozinra specifikus. A QVDLpe peptidhez SHP-2 kötődést nem tudtak kimutatni, míg a PLCgamma változatlan mértékben kötődött a rövid peptidhez. Ugyanakkor a foszfatáz aktivitás mérésekben ez a peptid jóval kisebb defoszforilációt mutatott a hat aminosavval hosszabb peptidhez képest.

Elmondható, hogy az SHP-2-t megkötő peptidek mintáiban PLCgamma és lyn tirozin kináz jelenlétét tudtuk kimutatni. Ennek alapján feltételezzük, hogy az SHP-2 vetélkedhet a PLCgamma-val a Gab1-hez való kötődésért, és így a Gab1 befolyásolhatja a PLCgamma aktivitását is.

A vizsgálatok szerint az összes rövidített szekvencia asszociálódott a PLCgammaval, viszont az SHP-2 -höz csak a 10 aminosav hosszúságú peptid kötődött. Az SHP-2vel kapcsolódni képes DKLDpe enzim aktivitást fokozó hatása a két rövidebb peptiddel (KQLDpe, QVLDpe) egyezett meg, amit az SHP-2 alapaktivitásának tulajdoníthatunk, és jóval kevésbé módosította az SHP-2 foszfatázaktivitását, mint a teljes hosszúságú GDLDpe peptid. 
A

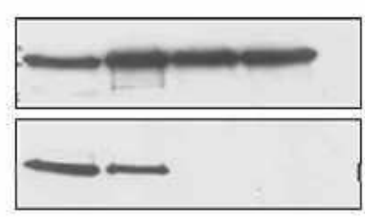

$\mathrm{Wb}$ :

PLCY

SHP-2

震 옿 $\underline{\text { GDKQVEY }}(\mathrm{p}) \operatorname{LDLDLD}$

DKQVEY(p)LDLD

$\underline{\operatorname{KQVEY}}(\mathrm{p}) \mathrm{LDLD}$

$\underline{\operatorname{QVEY}}(\mathrm{p}) \mathrm{LDLD}$

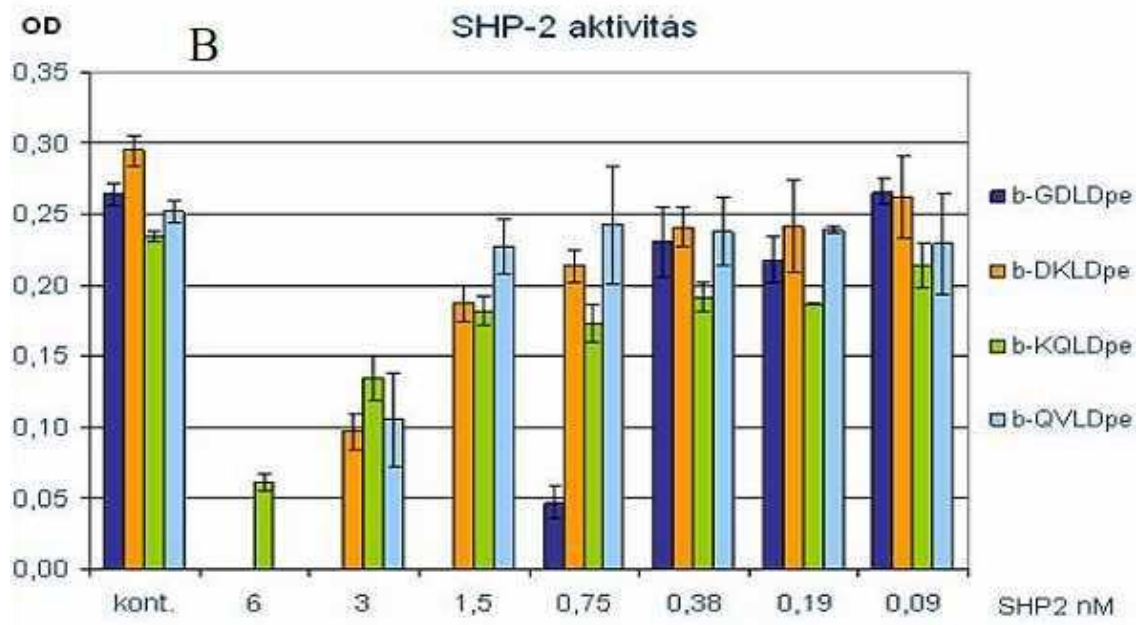

38. ábra: Néhány rövidített GDLDpe peptidhez asszociálódó fehérjék (A). A peptidek SHP-2 enzim aktivitást módosító hatása, a maradék foszfotirozint ábrázolva (B), ahol az alacsony optikai denzitás (OD) érték nagy SHP-2 aktivitást jelent.

3.5.3. Sejtpermeábilis hordozó-Gab1 eredetü foszfopeptid konjugátumok előállítása és vizsgálata a sejten belüli jelátviteli folyamatokban

Annak a kérdésnek a megválaszolására, hogy az YLDL motívumot tartalmazó peptid módosíthatja-e a sejten belüli jelátviteli folyamatokat, és milyen szerepet játszhat a natív molekulában, a sejtmembránon átjutó foszfopeptideket terveztünk és vizsgáltuk azok hatását a sejten belüli kalcium mobilizációjára. A PLCgamma-aktiválódás inozitol trifoszfát (IP3) felszabadulással jár, ami az endoplazmatikus retikulum IP3 receptoraihoz kötődve a sejten belüli raktárakból $\mathrm{Ca}^{2+}$ ionok felszabadulását eredményezi. A peptideket oktanoil csoport és nyolc arginin hozzákapcsolásával tettem alkalmassá arra, hogy a sejtmembránon átjussanak. 
Kontrollként ismét a GDLD és GDFLD peptideket használtuk és kíváncsiak voltunk még az előző kísérletekben már bizonyítottan az SHP-2-höz kapcsolódni képes rövidebb GDLDpe szekvenciára, a DKLDpe-re.

A kísérletekben felhasznált Okt-R8C-hez kapcsolt szintetikus, Gab1 eredetű peptid szekvenciákat a 21. táblázat foglalja össze.

21. táblázat: Az Okt-R8C sejtpermeábilis hordozóhoz kapcsolt Gab1 eredetü foszfopeptidek

\begin{tabular}{|l|l|}
\hline \multicolumn{1}{|c|}{ Kód } & \multicolumn{1}{c|}{ Szekvencia } \\
\hline Okt-R8C-GDLDpe & Oktanoil-RRRRRRRRC-NH- $\left(\mathrm{CH}_{2}\right)_{5}$-CO-GDKQVEY $(p)$ LDLDLD-NH $_{2}$ \\
\hline Okt-R8C-GDLD & Oktanoil-RRRRRRRRC-NH- $\left(\mathrm{CH}_{2}\right)_{5}$-CO-GDKQVEYLDLDLD-NH \\
\hline Okt-R8C-GDFLD & Oktanoil-RRRRRRRRC-NH- $\left(\mathrm{CH}_{2}\right)_{5}$-CO-GDKQVEFLDLDLD-NH \\
\hline Okt-R8C-DKLDpe & Oktanoil-RRRRRRRR-C-NH- $\left(\mathrm{CH}_{2}\right)_{5}$-CO-DKQVEY $(p)$ LDLD-NH $_{2}$ \\
\hline
\end{tabular}

A sejtpermábilis peptid (Okt-R8C) szintézise szilárd fázison történt Bockémiával. A felhasznált aminosavak: $\operatorname{Arg}(\mathrm{Tos}), \mathrm{Cys}(\mathrm{Meb})$. A kapcsolásokhoz 3-3 ekv. aminosav származékot és DCC-HOBt-t használtam. Az $N$-terminális oktanoil csoport beépítésére 4 ekv. mennyiségben kapcsoltam az oktánsavat ugyancsak 4-4 ekv. DCCHOBt jelenlétében a szabaddá tett $N^{\alpha}$-aminocsoporthoz. A kész terméket folyékony hidrogén-fluoriddal hasítottam le a gyantáról, szemipreparatív RP-HPLC-n tisztítottam és analitikailag jellemeztem (22. tábl.).

22. táblázat: Az Okt-R8C sejtpermeábilis hordozó analitikai paraméterei

\begin{tabular}{|c|c|c|c|c|}
\hline Kód & Szekvencia & $\mathbf{t}_{\mathbf{R}}{ }^{*}$ & $\mathbf{M}_{\text {számított }}$ & $\mathbf{M}_{\text {mért }^{\dagger}}$ \\
& & & & \\
\hline Okt-R8C & Oktanoil-RR $\left.]^{+}\right)$ \\
\hline
\end{tabular}

*: Retenciós idő meghatározása Agilent 1100 HPLC rendszeren (oszlop: Vydac Peptide \& Protein $10 \mu \mathrm{m}$ C18; 250x4.60 mm; áramlási sebesség: $1.2 \mathrm{ml} /$ perc; eluensek: A-Eluens: 0.1\% TFA/víz; B-Eluens: $80 \%$ acetonitril $/ 20 \%$ víz/ $0.1 \%$ TFA);

${ }^{\dagger}$ : MS (ESI ${ }^{+}$): $m / z$; monoizotópos molekulatömeg meghatározása Finnigan TSQ 7000 ESI-MS-en.

A peptideket a sejtpermeábilis hordozóhoz egy hosszabb szénláncot tartalmazó távolságtartón keresztül kapcsoltam. A gyantára kötött peptidek szabad $\mathrm{N}$-terminális $\alpha$ aminocsoportjához 3 ekv. mennyiségben $\varepsilon$-maleimido-kapronsavat kapcsoltam 3-3 ekv. DCC és HOBt segítségével. A reakciót ninhidrin-teszttel ellenőriztem. A peptidek gyantáról való hasítása a szokásos módon történt. A nyers $\varepsilon$-maleimido-kapronsavamidpeptideket kis térfogat foszfát pufferben ( $\mathrm{pH}$ 6.5) oldottam és hozzáadtam 1.5 ekv. Okt- 
R8C peptidet. A peptidek beoldását esetenként guanidin $\mathrm{HCl}$ sójával segítettem. 30 percenként mintát vettem a reakcióelegyből és analitikai RP-HPLC-re injektáltam, az oszlopról eluálódó csúcsokat ESI-MS-el ellenőriztem. A reakcióidő általában 1-2 óra volt, ezután a reakcióelegyet szemipreparatív RP-HPLC-re injektálás után tisztítottam. A tisztított termékeket retenciós idejük, valamint molekulatömegük alapján jellemeztem (23. táblázat).

23. táblázat: Az Okt-R8C sejtpermeábilis hordozóhoz kapcsolt Gab1 eredetű foszfopeptidek és származékainak analitikai paraméterei

\begin{tabular}{|c|c|c|c|c|}
\hline Kód & $\begin{array}{c}\text { Analitikai HPLC } \\
\text { gradiens }\end{array}$ & $\begin{array}{c}\mathbf{t}_{\mathrm{R}}{ }^{*} \\
(\text { perc) }\end{array}$ & $\mathbf{M}_{\text {számított }}$ & $\begin{array}{c}\mathbf{M}_{\text {mért }}^{\dagger} \\
\left([\mathbf{M}+\mathbf{H}]^{+}\right)\end{array}$ \\
\hline Okt-R8C-GDLDpe & $20-50(\% \mathrm{~B}) ; 30 \mathrm{~min}$ & 12.59 & 3289.9 & 3290 \\
\hline Okt-R8C-GDLD & $30-45$ (\%B); 15 perc & 8.70 & 3209.9 & 3210 \\
\hline Okt-R8C-GDFLD & $30-60(\% B) ; 30$ perc & 13.54 & 3193.0 & 3194 \\
\hline Okt-R8C-DKLDpe & $28-43(\% \mathrm{~B}) ; 15$ perc & 6.66 & 3004.5 & 3005 \\
\hline
\end{tabular}

*: Retenciós idő meghatározása Agilent 1100 HPLC rendszeren (oszlop: Hypersil nucleosil $10 \mu \mathrm{m}$ C18; 250x4.60 mm; áramlási sebesség: $1.0 \mathrm{ml} /$ perc; eluensek: A-Eluens: $0.1 \% \mathrm{TFA} / \mathrm{víz}$; B-Eluens: $80 \%$ acetonitril $/ 20 \%$ víz/ $0.1 \%$ TFA);

${ }^{\dagger}$ : MS $\left(\mathrm{ESI}^{+}\right): m / z$; monoizotópos molekulatömeg meghatározása Finnigan TSQ 7000 ESI-MS-en.

A következőkben azt vizsgáltuk, hogy a sejtbe juttatott foszfopeptidek befolyásolják-e a sejten belüli fehérje-fehérje kölcsönhatások létrejöttét, milyen hatást gyakorolnak az intracelluláris fehérje foszforilációs mintázatra.

Gab1 specifikus ellenanyaggal tisztították a Gab1 fehérjét különböző ideig aktivált BL 41 sejtek lizátumából. Az Okt-R8C-GDLDpe peptid jelenlétében a PLC-gamma és az SHP-2 kötődése a Gab1-hez nem volt kimutatható, míg a PI3-K jelenlétét a rövid ideig aktivált mintákban a peptid jelenléte nem befolyásolta. 20 perc aktiválást követően a PI3-K leválik a Gab1-ről, feltehetőleg az SHP-2 Gab1-et defoszforiláló aktivitása eredményeképpen. 

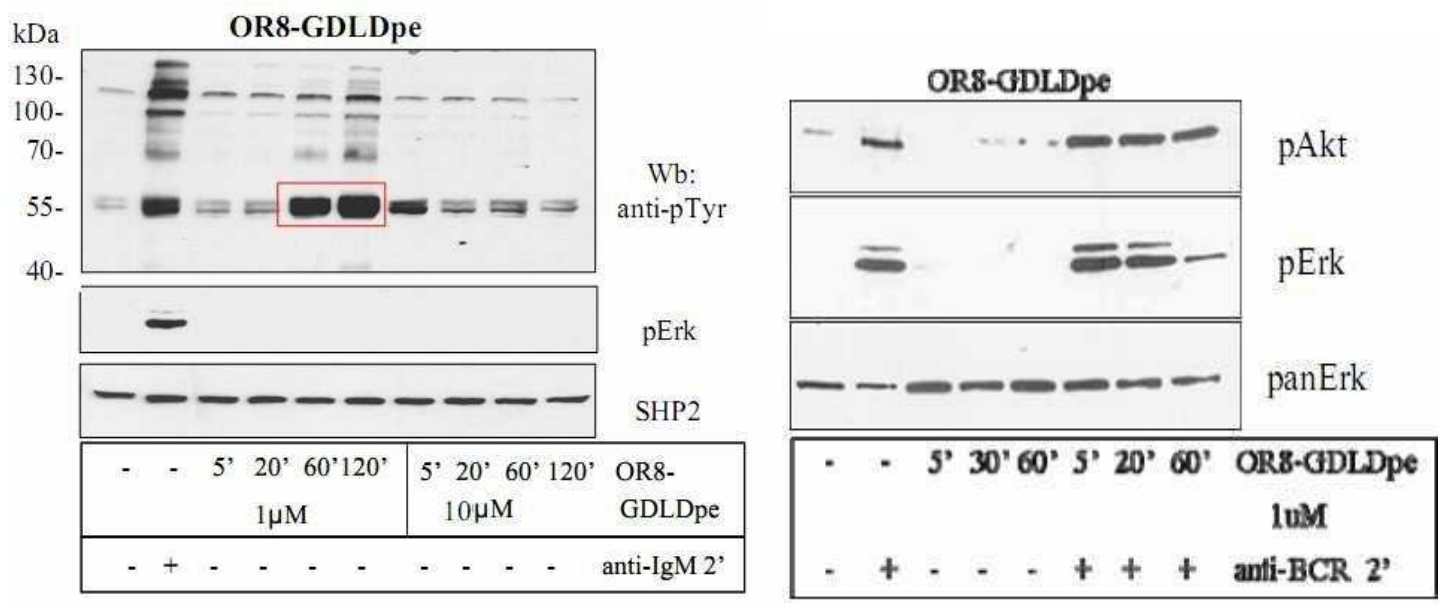

39. ábra: Az Okt-R8C-GDLDpe peptid hatására kialakuló fehérje-foszforilációs állapotváltozás nyugvó Bsejtekben (bal). Kontrollként kezeletlen és BCR keresztkötött mintákat alkalmaztak; Az Erk foszforiláció gátlása a 60 perces előkezelést követően (jobb).

Érdekes, hogy a tirozinon nem foszforilált Okt-R8C-GDLD az Okt-R8CGDLDpe-hez hasonlóan gátolta az anti-IgM indukált Erk foszforilációt az 5 percig előkezelt mintákban.

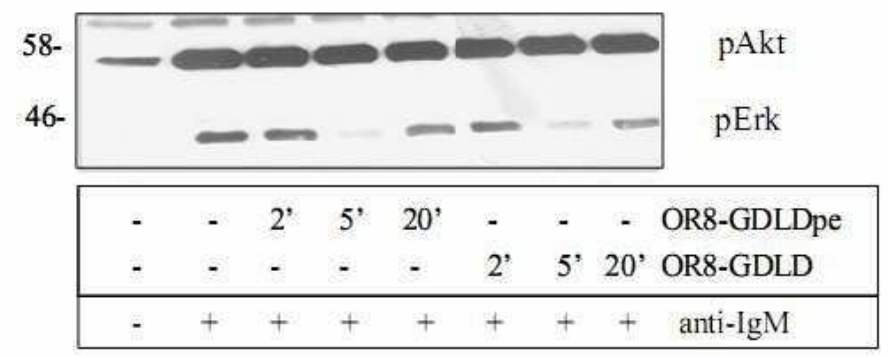

40. ábra: Az Okt-R8C-GDLD foszforilált és nem foszforilált formája egyaránt gátolta az anti-IgM által indukált Erk aktivációt. Feltételezzük, hogy a sejtbe jutott peptideket az intracelluláris kinázok foszforilálják.

Mivel az előzetes in vitro kísérletekben bebizonyosodott, hogy ez a peptid nem kötődik az SHP-2 tirozin foszfatázhoz, úgy gondoljuk, hogy a sejtbe jutva kinázok által foszforilálódhatott és ezáltal nyert biológiai aktivitást. Így az Okt-R8C-GDFLD peptidet használtuk negatív kontrollként.

Jelenleg a GDLDpe rövidített formáját (Okt-R8C-DKLDpe) vizsgáljuk, amely az SHP-2-höz még kötődik, de az enzim aktivitást fokozó hatása jóval gyengébb az eredeti szekvenciánál (Okt-R8C-GDLDpe). 
Az Okt-R8C-GDLDpe foszfopeptid kis mértékü, de reprodukálható, gyors $\mathrm{Ca}^{2+}$ felszabadulást váltott ki. Ennek alapján azt feltételeztük, hogy a foszfopeptid valószínüleg SH2 doménekhez való kötődését a PLCgamma aktiválja.

A Gab1 szerepe a B-sejtekben elsősorban az Erk aktiválása. Az eredmények alapján úgy gondoljuk, hogy a sejtpermeábilis foszfopeptidek gátolni képesek a Gab1/SHP-2 és Gab1/PI3-K fehérje kölcsönhatások kialakulását és ezáltal módosíthatják a proliferációs, apoptotikus és túlélési szignálokat. A Gab fehérjék tehát az immunsejtekben éppúgy mint a tumorsejtekben kulcsszerepet játszanak különféle jelátviteli útvonalak során.

A proliferáció gátlásában, illetve az apoptózis fokozásában hatásosnak bizonyuló foszfopeptidek alapjául szolgálhatnak farmakológiailag aktív peptidomimetikumok tervezésének akár B-sejtes, akár más típusú tumorok esetén.

\subsection{Mozgékony fehérje térszerkezeti elemek konformációs egyensúlyának vizsgálata $\beta$-modellpeptidekkel és minifehérjékkel}

Habár a minifehérjének nincsen általánosan elfogadott definiciója, néhány közös jellemző mindegyikükre igaz. A legfontosabb ezek közül a harmadlagos szerkezet. Ennek kialakításában a minifehérjét alkotó összes másodlagos szerkezeti elem ( $\alpha$-hélix, $\beta$-redő és a különböző kanyar régió) kooperatívan részt vesz.

A fehérje tervezés egyik ága a minifehérjék már meglévő fehérjék szekvenciamódosításával történő létrehozására („redesign” módszer) irányul. Peptidek másik tervezési módja a „de novo” tervezési módszer, amely során fehérje adatbázisok statisztikai vizsgálatára és ab initio számításokra támaszkodva eddig ismert peptidektől és fehérje részletektől független aminosav sorrendű modellpeptidet állítanak elő.

Santiveri és munkatársai ily módon terveztek 3:5 $\beta$-hajtükanyar téralkatú peptideket [99, 100]. Az így elóállított peptidek 30-50\%-a mutatott vizes oldatban rendezett térszerkezetet, 30\% trifluoretanol hozzáadásának hatására ez az érték $60-80 \%$ ra emelkedett. A legnagyobb térszerkezeti populációval rendelkező peptid a SETE

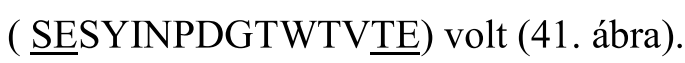




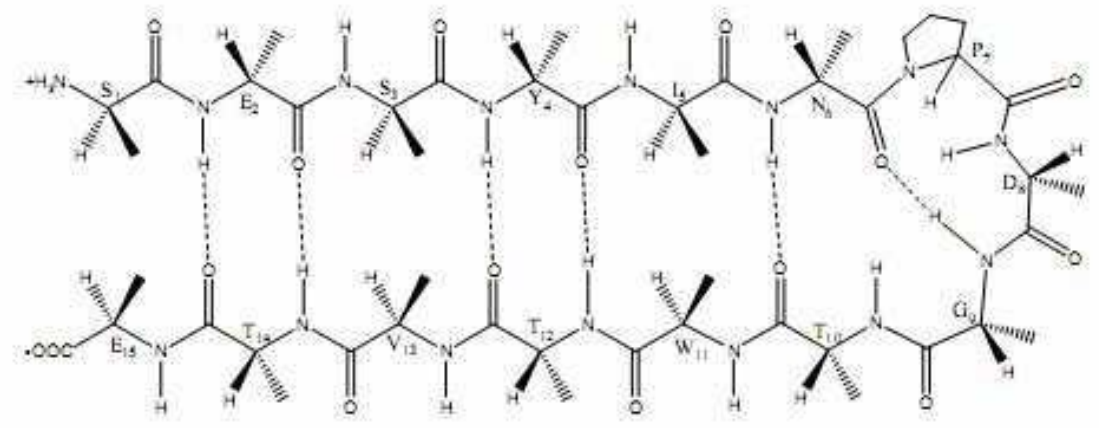

41. ábra: A 3:5 $\beta$-hajtűkanyar téralkatú SETE (a térszerkezet stabilizáló hidrogénkötéseket szaggatott vonal jelzi

Kortemme és munkatársai korábban megtervezett $\beta$-hajtükanyar térszerkezetű peptideket használtak fel egy 20 aminosavból álló háromszálú $\beta$-redőzött réteg térszerkezetü minifehérje, a Betanova (RGWSVQNGKYTNNGKTTEGR) ab initio módszerrel történő tervezésében [101, 102] (42. ábra).

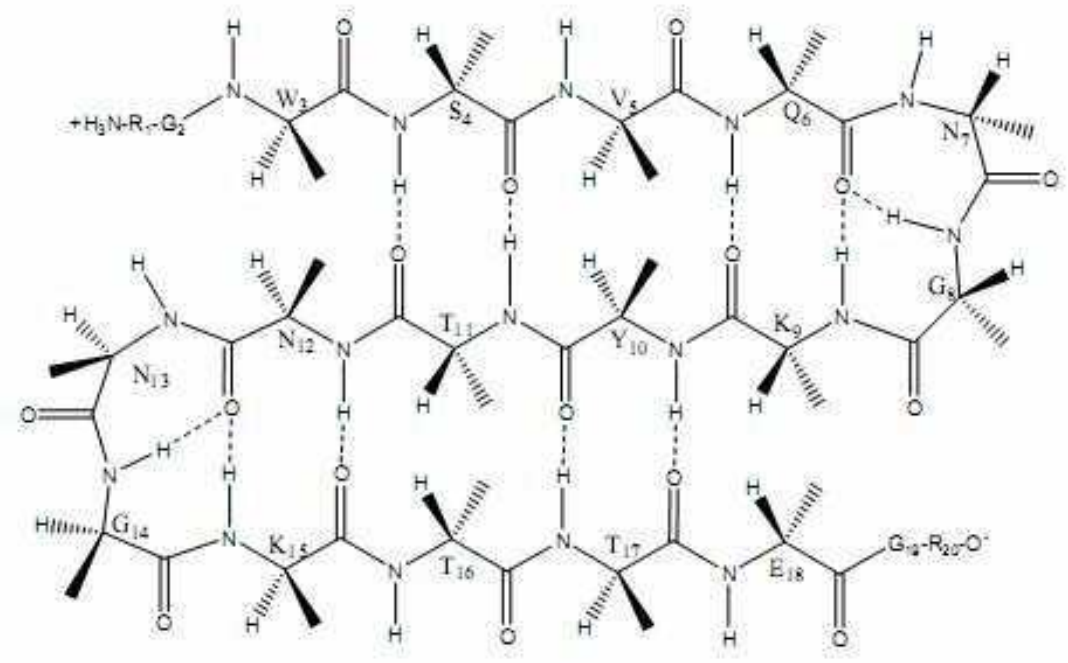

42. ábra: A Betanova feltételezett háromszálú antiparalell $\beta$-redőzött téralkata

A ma ismert legkisebb és legstabilabb a priori tervezett minifehérjéje a Tc5b (NLYIQWLKDGGPSSGRPPPS), vagy más néven Trp-kalitka. Neidigh és munkatársai a Gila monster viperagyík nyálában megtalálható 39 aminosav hosszú helikális polipeptidből indultak ki (exendin-4), és számos csonkítás és mutáció után 20 aminosavra csökkentették a fehérje méretét úgy, hogy közben szerkezetét is stabilizálták [103]. Felépítésében egy $\alpha$-hélix, egy 310 -hélix és egy poliprolin II típusú hélix szerveződik a 
központi triptofán köré. Az így előállított kompakt, globuláris minifehérje több mint 95\%-ban feltekeredett állapotban van jelen vízben.

24. táblázat: Az előállított $\beta$-modellpeptidek és minifehérjék szekvenciái és analitikai jellemzői

\begin{tabular}{|c|c|c|c|c|c|}
\hline Kód & Szekevencia & $\begin{array}{c}\text { Anal. HPLC } \\
\text { grad. }\end{array}$ & $\begin{array}{c}\mathbf{t}_{\mathrm{R}}{ }^{*} \\
\text { (perc) }\end{array}$ & $\mathbf{M}_{\text {számított }}$ & $\begin{array}{c}\mathbf{M}_{\text {mért }^{\dagger}} \\
\left([\mathbf{M}+\mathbf{H}]^{+}\right)\end{array}$ \\
\hline Betanova-OH & RGWSVQNGKYTNNGKTTEGR-OH & $\begin{array}{c}17-32(\% \mathrm{~B}) \\
15 \text { perc }\end{array}$ & 8.774 & 2253.4 & 2254 \\
\hline Betanova- $\mathrm{NH}_{2}$ & RGWSVQNGKYTNNGKTTEGR-NH ${ }_{2}$ & $\begin{array}{c}20-35(\% \mathrm{~B}) \\
15 \text { perc }\end{array}$ & 10.562 & 2252.4 & 2253 \\
\hline SETE & SESYINPDGTWTKTE-OH & $\begin{array}{c}28-43(\% \mathrm{~B}) \\
15 \text { perc }\end{array}$ & 7.136 & 1727.8 & 1728 \\
\hline SETE-S3(p) & $\operatorname{SES}(p)$ YINPDGTWTKTE-OH & $\begin{array}{c}24-39(\% \mathrm{~B}) \\
15 \text { perc }\end{array}$ & 7.552 & 1807.8 & 1808 \\
\hline SETE-S3E & SEEYINPDGTWTKTE-OH & $\begin{array}{c}28-43(\% \mathrm{~B}) \\
15 \text { perc }\end{array}$ & 6.950 & 1769.8 & 1770 \\
\hline ERVSK & ERVYINPDGTWTVSK-OH & $\begin{array}{c}30-45(\% \mathrm{~B}) \\
15 \text { perc }\end{array}$ & 7.017 & 1764.9 & 1765 \\
\hline ERISK & ERIYINPDGTWTVSK-OH & $\begin{array}{c}31-46(\% \mathrm{~B}) \\
15 \text { perc }\end{array}$ & 7.138 & 1778.9 & 1779 \\
\hline ESVSK & ESVYINPDGTWTVSK-OH & $\begin{array}{c}30-45(\% \mathrm{~B}) \\
15 \text { perc }\end{array}$ & 7.120 & 1695.8 & 1696 \\
\hline ESISK & ESIYINPDGTWTVSK-OH & $\begin{array}{c}32-47(\% \mathrm{~B}) \\
15 \text { perc }\end{array}$ & 6.875 & 1709.8 & 1710 \\
\hline Tc5b-S13(p) & NLYIQWLKDGGPS $(p)$ SGRPPPS-OH & $\begin{array}{c}32-47(\% \mathrm{~B}) \\
15 \text { perc }\end{array}$ & 8.158 & 2249.4 & 2250 \\
\hline $\begin{array}{l}\text { Tc5b- } \\
\text { monoszach. }\end{array}$ & LKN[GlkNAc $(\beta 1-\mathrm{N})] \mathrm{GGP}-\mathrm{OH}$ & $\begin{array}{c}8-23(\% \mathrm{~B}) ; \\
15 \text { perc }\end{array}$ & 8.876 & 788.0 & 789 \\
\hline Tc5b-diszach. & LKN[GlkNAc( $\beta 1-4) \operatorname{GlkNAc}(\beta 1-N)]$ GGP-OH & $\begin{array}{c}15-35(\% \mathrm{~B})^{* *} \\
20 \text { perc }\end{array}$ & 9.621 & 991.1 & 992 \\
\hline
\end{tabular}

*: Retenciós idő meghatározása Agilent 1100 HPLC rendszeren (oszlop: Hypersil nucleosil 10 $\mu \mathrm{m}$ C18; 250x4.60 mm; áramlási sebesség: $1.0 \mathrm{ml} /$ perc; eluensek: A-Eluens: 0.1\% TFA/víz; B-Eluens: 80\% acetonitril/20\% víz/0.1\% TFA); **: A-Eluens: $0.05 \mathrm{M} \mathrm{NH}_{4} \mathrm{OAc}$ puffer (pH 6.5); B-Eluens: $60 \% \mathrm{MeOH} /$ $0.05 \mathrm{M} \mathrm{NH}_{4} \mathrm{OAc}$ puffer (pH 6.5);

${ }^{\dagger}: \mathrm{MS}\left(\mathrm{ESI}^{+}\right.$): $m / z$; monoizotópos molekulatömeg meghatározása Finnigan TSQ 7000 ESI-MS-en.

A Betanova peptid esetében elóállítottam a Kortemme és munkatársai által definiált karboxil végü peptidet és a $C$-terminálison savamidvégü szekvenciát. A peptidek manuális szilárd fázisú szintézissel készültek, a karboxil végü peptid Merrifield 
polimeren, az amid végü MBHA hordozón. A két szintézis a $C$-terminális aminosav gyantára kapcsolásában tér el, a Merrifield polimer esetében az aminosavat kálium só formájában kapcsoltam, míg az MBHA hordozóhoz való kapcsolásnál DCC-vel aktivált aminosavat kapcsoltam. A peptidlánc felépítéséhez használt aminosavak hidrogénfluoridra hasítható oldallánc védőcsoporttal rendelkeztek, kapcsolószerként DCC-t és HOBt-t használtam 3-3 ekv. mennyiségben. A kész peptideket hidrogén-fluoriddal hasítottam, gyökfogóként anizolt, dimetil-szulfidot és $p$-krezolt használtam. A nyers peptideket kromatográfiásan tisztítottam és analitikailag jellemeztem (24. táblázat).

A szintetizált háromszálú $\beta$-redőzött réteg téralkatú minifehérjék esetén Perczel és társai konformációs egyensúlyi vizsgálatokat végeztek vízben, homonukleáris NMR spektroszkópia segítségével. Kimutatható volt, hogy a Betanova térszerkezete, ellentétben a korábbi állítással, miszerint e molekula egyetlen stabil téralkattal jellemezhető, több konformációs állapot egyensúlyi rendszerével írható le a $\beta$-redőzött réteg térszerkezetü polipeptid láncok mozgékonysága miatt [104]. A Betanova- $\mathrm{NH}_{2}$ esetében végzett molekuladinamikai szimuláció eredményét a 43. ábra mutatja be.
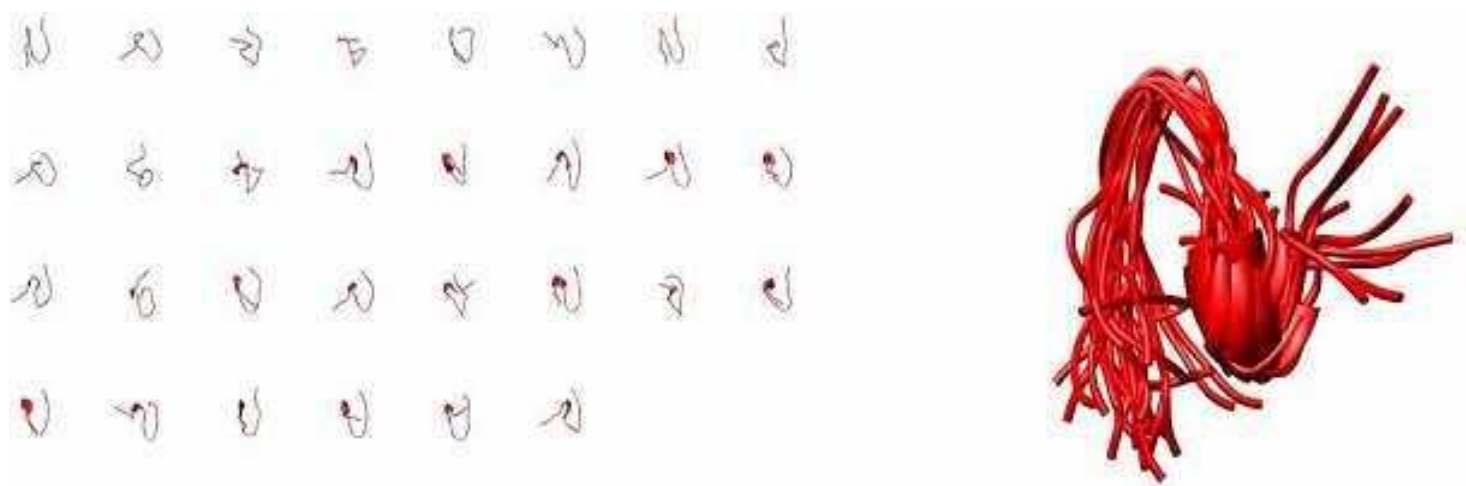

43. ábra: A Betanova- $\mathrm{NH}_{2}$ modellpeptiden végzett szimulált hőkezelés protokollt alkalmazó molekuladinamikai szimuláció eredményeképpen kapott 50 térszerkezetből elfogadott 30 konformer egyedi rajzolata és az elfogadott téralkatok közül a hasonlók egymásra illesztett képe. A 30 konformer mind teljesíti a kényszerfeltételeket, de különbözőségük folytán nem sorolható konformercsaládba.

Az általam szintetizált SETE-peptidek (24. táblázat) közt megtalalálható a Santiveri és munkatársai által definiált szekvencia is, valamint a 3. pozícióban foszforilált szerin vagy glutaminsav helyettesítéseket tartalmazó származék.

A SETE és SETE-S3E peptidek szintézise manuális szilárd fázisú Boc-kémiával történt Merrifield polimeren. A beépített aminosavak HF-ra hasítható oldallánc 
védőcsoporttal rendelkeztek. A kapcsoláshoz 3-3 ekv. Boc aminosav származékot, DCC-t és HOBt-t használtam. A kész peptideket a gyantáról folyékony HF-dal hasítottam le.

A SETE-S3(p) peptid szintézise szilárd fázisú Fmoc-kémiával készült Wang hordozón. A felhasznált aminosavak oldallánc védőcsoportjai TFA-val hasíthatók voltak a $\mathrm{S}^{3}$ kivételével, melyet védőcsoport nélkül építettem be. A $C$-terminális aminosav kapcsolásához 4-4 ekv. aminosavat, DCC-HOBt-t, valamint 1 ekv. 4-dimetil-aminopiridint használtam, minden további aminosav kapcsolásához háromszoros fölöslegben használtam a reagenseket. A foszfoszerin kiépítésére az "online" foszforiláció módszerét választottam. Így a $\mathrm{S}^{3}$ oldalláncába a foszfátészter beépítése két lépésben valósult meg: első lépés a védőcsoport nélküli szerin foszfonilálása $20 \mathrm{ekv}$. terc-butil- $H$-foszfonát és 40 ekv. pivaloil-klorid jelenlétében, 1:1 (v/v) piridin/DMF-et használva oldószerként; ezt követte az oxidáció $1(\mathrm{~m} / \mathrm{v} \%)$ jód tartalmú, 98:2 (v/v) arányú piridin/víz eleggyel. A folyamatot a 44. ábra illusztrálja:<smiles>CCNC(CO)C(C)=O</smiles>$$
\stackrel{\text { pivaloil klorid, DMF, piridin }}{\longrightarrow}
$$

ii) $1 \% \mathrm{I}_{2}$ piridin/víz (98:2)

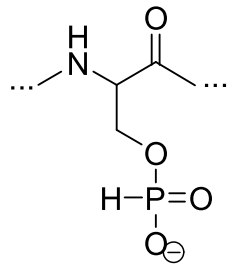

44. ábra: A Ser „online” foszforilációja

A peptid hordozóról való lehasítása 95 (v/v\%) TFA-val történt, amely gyökfogóként $3(\mathrm{~m} / \mathrm{v} \%)$ DTT-t tartalmazott. A nyers peptidet éteres kicsapással kaptam meg, majd szemipreparatív RP-HPLC-vel tisztítottam.

A SETE, SETE-S3E valamint a SETE-S3(p) esetében végzett konformációs egyensúlyi vizsgálatok esetén kimutatható, hogy mindhárom SETE-származék modellpeptidre a kanyar régióknál megfelelő az egy konformercsaládhoz tartozó számolt szerkezetek illeszkedése, míg a láncvégek felé haladva az illeszkedés egyre romlik (45. ábra).

Az eredmények alapján megállapíthatjuk, hogy ezeknek a peptideknek jelentős a belső mozgékonyságuk, valamint, mivel az NOE adatok alapján adott kényszerfeltétel- 
együttes segítségével végzett szimulált hőkezeléses eljárással több szerkezetet is kapunk, megállapítható, hogy a vizsgált peptidek egyetlen téralkattal helyesen nem jellemezhetők.

A)
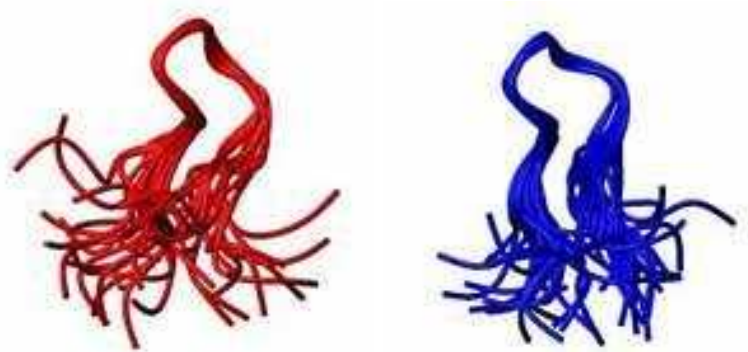

B)
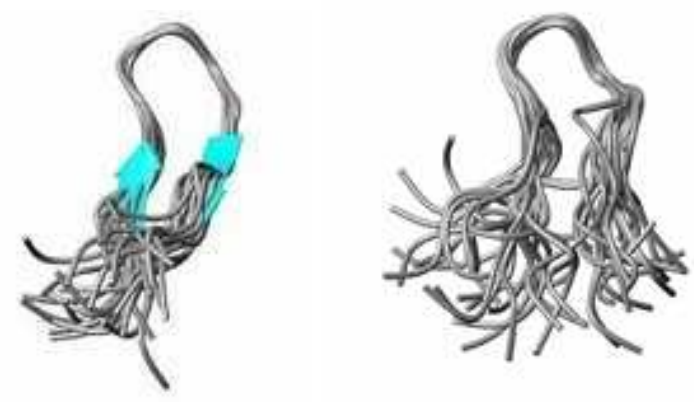

C)
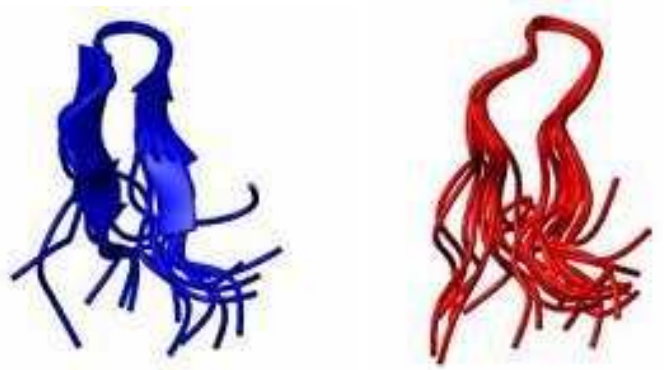

45. ábra: A SETE-típusú modellpeptideken végzett szimulált hőkezelés protokollt alkalmazó molekuladinamikai szimuláció eredményeképpen kapott két fő konformercsaládba osztható térszerkezetek egymásra illesztett képe A) SETE, B) SETE-S3(P), C) SETE-S3E esetén. A számolt 50 térszerkezet mindegyikére teljesül az összes ${ }^{1} \mathrm{H}-{ }^{1} \mathrm{H}$ NOE kényszerfeltétel.

A láncvégi illeszkedések stabilizálására terveztük az ERVSK, ERISK, ESVSK és ESISK módosított szekvenciákat. A peptideket Merrifield polimeren állítottam elő szilárd fázisú szintézissel Boc/Bzl-stratégiával az eredeti szekvenciánál már leírt módon. A nyers peptideket kromatográfiásan tisztítottam és analitikailag jellemeztem (24. táblázat).

A tervezett SETE mutánsokban a 3:5 $\beta$-hajtükanyar térszerkezet stabilizálásában résztvevő aminosavak környezetének módosításával céloztuk ezen konformáció stabilizálását (46. ábra). 


\begin{tabular}{clll} 
3:5 $\beta$-kanyar & \multicolumn{2}{l}{ 3:5 $\boldsymbol{\beta}$-kanyar } & ERVYINPDGTWTVSK \\
S E S Y I N P & E R V/I Y I N P & ERIYINPDGTWTVSK \\
II II I D & II II I D & ESVYINPDGTWTVSK \\
E T V T W T G & K S V T W T G & ESIYINPDGTWTVSK
\end{tabular}

46. ábra: A tervezett SETE-mutánsok

A mutánsok esetében felvett $\mathrm{CD}$ spektrumok a konformáció változását tükrözik hődenaturáció, illetve $\mathrm{pH}$ hatására:
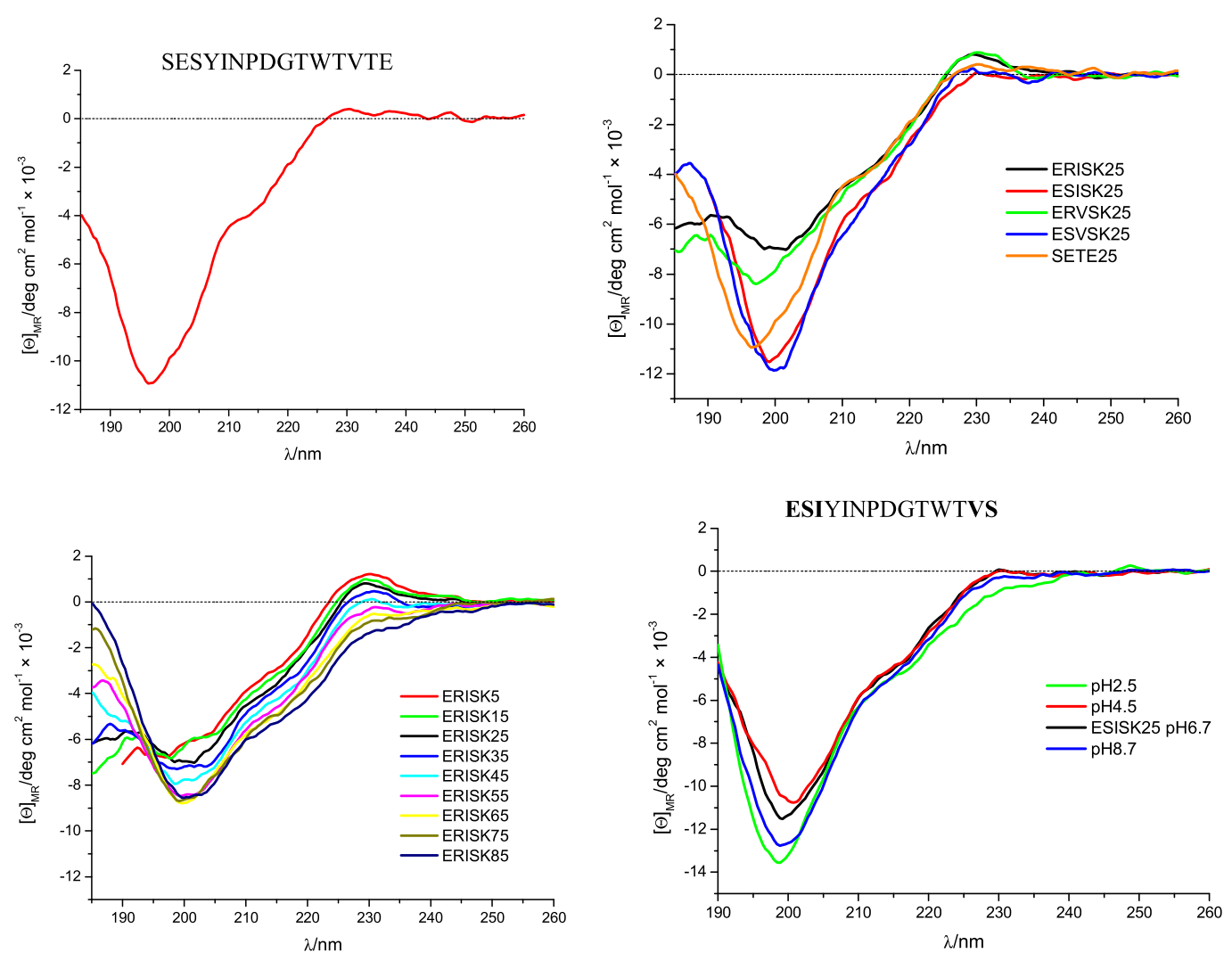

47. ábra: Néhány SETE-peptid CD-spektruma

Ezen peptidek a $\beta$-hajtükanyar térszerkezet stabilizálásában játszott szerepének vizsgálata folyamatban van.

Az aszparaginon glikozilált peptidek szintézisére modellnek kiválasztott hexapeptid (LKDGGP) a Tc5b minifehérje 7-12 fragmense. Cukor részként $N$-acetilglükózamint és kitobiózt építettem be. A glikoziláció térszerkezeti hatásainak vizsgálatára korábban már szintetizáltuk a teljes minifehérjét és módosított származékait galaktozil aszparaginnal [105]. Ebben az esetben a 9. pozícióba galaktozil aszparagint 
építettünk be a peptidláncba Fmoc-stratégia felhasználásával. E munka keretein belül olyan módosítást végeztem, amely során a Tc5b szekvencia 13-as szerinjét foszforiláltam.

A Tc5b-S13(p) peptidet Wang polimeren szintetizáltam Fmoc-stratégiával. A beépített aminosavak oldallánc védőcsoportjai TFA-val hasíthatók voltak a $\mathrm{S}^{13}$ kivételével, melyet védőcsoport nélkül építettem be. A kapcsoláshoz 3-3 ekv. Fmocaminosav származékot, DCC-t és HOBt-t használtam.

A foszfoszerin tartalmú peptid szintézisére az úgynevezett „online” foszforiláció módszerét alkalmaztam. A 13-as Ser szabad alkoholos hidroxil csoportját első lépésben foszfoniláltam 20 ekv. ammónium terc-butil $H$-foszfonáttal, 40 ekv. pivaloil klorid és piridin jelenlétében, majd egy következő lépésben oxidáltam $1(\mathrm{~m} / \mathrm{v} \%)$ jód tartalmú piridin/víz 98:2 (v/v) elegyében. A peptidlánc a Fmoc-csoport hasításával építődik tovább. A kész peptidet a gyantáról 95 (v/v\%) TFA-val hasítottam le, gyökfogóként DTT-t használtam. A nyers peptidet szemipreparatív RP-HPLC-n tisztítottam és analitikailag jellemeztem (24. táblázat).

Kerékgyártó és munkatársai synthonként elöállították a teljesen $O$-benzilezett glikozil azidokat: $\quad \operatorname{GlkNAc}\left(\beta 1-N_{3}\right), \quad \operatorname{GlkNAc}(\beta 1-4) \operatorname{GlcNAc}\left(\beta 1-N_{3}\right)[106]$. Ezekbö1 állították elő egy kemoszelektív redukcióval a glikozil aminokat. Az in situ kapcsolási reakció a glikozil aminok, valamint a szelektíven védett, aktivált aszparaginsav között a szénhidrát-aszparaginsav származékokat eredményezte. Ezek katalitikus hidrogénezével kapott építőköveket (48. ábra) használtam fel a glikopeptidek szintézise során.
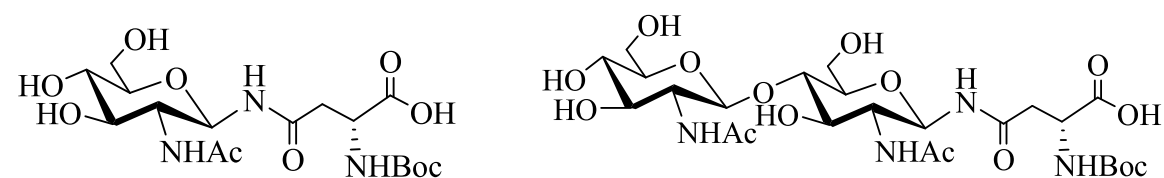

48. ábra: A glikopeptidek szintéziséhez használt szénhidrát-aszparaginsav építőkövek

A glikopeptidek Boc-Pro-Merrifield polimeren készültek szilárd fázisú Bocstratégiával. A beépített aminosavak közül a Lys tartalmazott oldallánc védelmet, ezúttal Boc-Lys(Z)-OH-t használtam. A glikozilált aszparaginsav származék beépítése hasonló módon történt, mint a többi aminosav származéké, 3-3 ekv. DCC-t és HOBt-t használtam. A peptidet a gyantáról $10(\mathrm{v} / \mathrm{v} \%) \operatorname{HBr}[33(\mathrm{v} / \mathrm{v} \%)$-os oldat jégecetben] TFA oldatával hasítottam le, gyökfogóként $2(\mathrm{~m} / \mathrm{v} \%)$ DTT-t használtam. 
A GlkNAc( $(\beta 1-\mathrm{N})$ Asn tartalmú glikopeptid szintézisénél jó termeléssel kaptam a kívánt terméket, amely korrekt tömegspektrummal rendelkezett. A GlkNAc( $\beta 1$ 4)GlkNAc( $\beta 1-N) A s n$ tartalmú glikopeptid védőcsoport eltávolítása során a kívánt diszacharid-hexapeptid származék mellett egy monoszacharid egység lehasadása is megfigyelhető volt. Az $O$-glikozidkötés hasadásával keletkező melléktermék mennyisége összemérhető volt a kívánt termékével. Sem a reakcióidő, sem a hasítási reakcióelegy változtatása nem okozott érdemi javulást.

A probléma áthidalására új stratégiát próbáltam ki. Elsődlegesen egy fluorén származékot állítottam elő: $N$-[(9-hidroximetil)-2-fluorenil]borostyánkősavat (49. ábra), amelyet aztán szekunder amin érzékeny linkerként használtunk fel [107, 108].

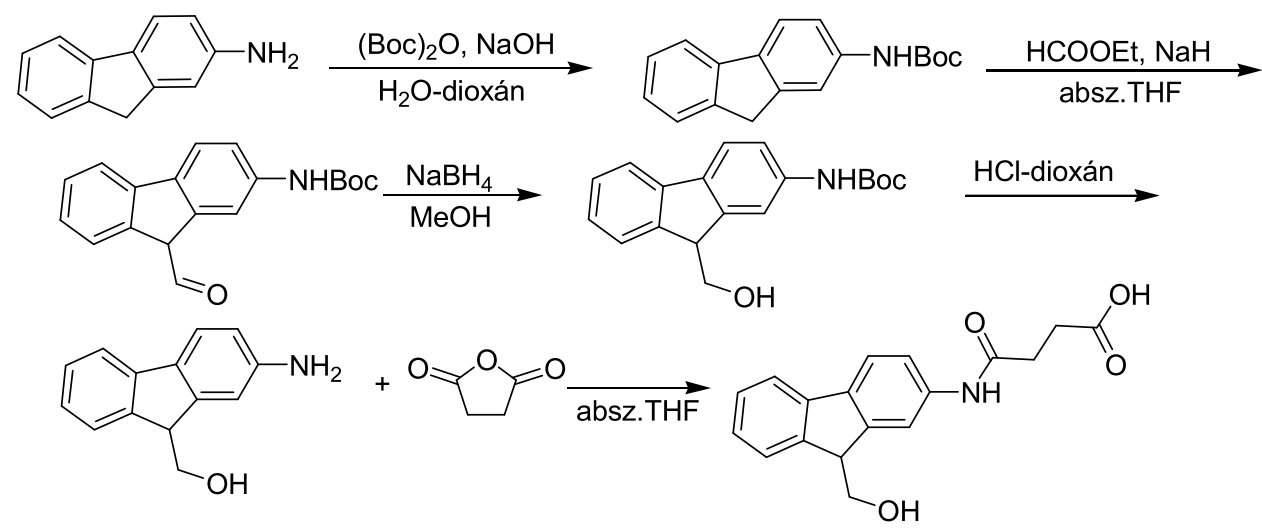

49. ábra: Az N-[(9-hidroximetil)-2-fluorenil]borostyánkősav linker előállítása

A hasítás a szintézis végén piperidin/dimetilformamid oldattal történt, de az $O$ glikozidok hasadása itt is megfigyelhető volt, bár az előzőnél kisebb mértékben. A kapott nyers terméket szemipreparatív RP-HPLC-vel tisztítottam TFA-mentes eluenseket használva: A-eluens ammónium-acetát puffer $(0.05 \mathrm{M}, \mathrm{pH} 6.5)$, B-eluens $60 \% \mathrm{MeOH} /$ ammónium-acetát puffer (0.05 M, pH 6.5). Ezzel a módszerrel a diszacharid tartalmú hexapeptid izolálása kielégítő hozammal történt.

Az előállított Tc5b analógok szerkezetvizsgálata folyamatban van.

Összeségében megállapítható, hogy a vizsgált peptidek belső mozgékonysága még mindig jelentős, tehát szükség van további módosításokra egy még stabilabb szerkezet eléréséhez. Mivel az NOE adatok alapján adott kényszerfeltételegyüttes segítségével végzett szimulált hőkezeléses eljárással több szerkezetet is kapunk, megállapítható, hogy a vizsgált peptidek egyetlen téralkattal helyesen nem jellemezhetőek, azonban sikerült 
leszükíteni a lehetséges szerkezetek számát az egyik modellpeptid esetében - SETE-S3E peptid. Ez a peptid a továbbiakban hasznos modellként szolgálhat $\beta$-hairpin rendszerek tanulmányozására. 


\section{Anyagok és módszerek}

\subsection{Felhasznált vegyszerek}

A szintézisek során használt oldószerek többségét további tisztítás nélkül használtam fel, ezeket (DCM, DMF, MeOH, DIEA, TEA, TFA) a Sigma Aldrich (Németorzág), az aminosavak többségét az Orpegen (Németország), a Bachem (USA), a Reanal (Magyarország) és a Chem-Impex (USA), a kapcsolószereket a Bachem (USA) ill. az Iris Biotech (USA) szállította. Néhány reakcióhoz a szükséges puffereket én állítottam elő, a szükséges sókat a Fluka (Németország) szállította. A HPLC-minőségü oldószerek közül az acetonitrilt a Merck (Németország), a TFA-t a Sigma-Aldrich (Németország) biztosította. A hordozókat a Varian (Anglia), a Senn Chemicals (Svájc), a Chem Impex (USA) cégektől vásároltuk, kivéve a Clear-ox ${ }^{\mathrm{TM}}$ gyantát, azt a Peptides International (USA) szállította. A többi felhasznált reagenst a Fluka (Németország) és a Sigma-Aldrich (Németország) biztosította.

\subsection{Szilárd fázisú peptidszintézis}

4.2.1. A peptidlánc felépítése

A peptidlánc felépítése a szilárd fázisú peptidszintézis módszerével, leggyakrabban a Boc/Bzl, illetve Fmoc/tBu technika alkalmazásával történhet. A kezdő lépés az első $N$-védett aminosav kapcsolása gyantára. Wang polimer esetében a hordozó és az aminosav közötti észterkötés kialakítását általában karbodiimid reagens segítségével végzik. Mivel az alkoholos hidroxilcsoport gyenge nukleofil, a reakció báziskatalízissel történik, ehhez leggyakrabban 4-dimetil-amino-piridint (DMAP) használunk. MBHA hordozó esetében az első aminosav kapcsolása történhet karbodiimidekkel, szimmetrikus anhidriddel, egyes aktív észterekkel, vagy foszfónium és urónium származékokkal is. Az MBHA hordozót a gyártók általában hidroklorid-sóként hozzák forgalomba, az első aminosav felkapcsolása előtt az aminocsoportot szerves bázissal, például trietilaminnal, fel kell szabadítani. Az Fmoc-stratégiában használt Rink, TentaGel gyanták Fmoc-csoporttal védve kerülnek forgalomba, ezért ezekről az első aminosav kapcsolása előtt el kell távolítani a védőcsoportot. Merrifield polimer esetén az első aminosavat kálium-só formájában tudjuk felkapcsolni a szilárd hordozóra. 
A Boc/Bzl kémiában az $\alpha$-aminocsoport átmeneti védésére használt Boc-csoport $50(\mathrm{v} / \mathrm{v} \%)$ trifluorecetsav (TFA) diklórmetán (DCM) oldatával eltávolítható. A védőcsoport eltávolításához egy 5, majd 25 perces kezelés elegendő. A védőcsoport eltávolítása után az ammóniumsó semlegesítése következik $10(\mathrm{v} / \mathrm{v} \%)$ trietilamin (TEA) diklórmetános oldatával (kétszer 1 perc), hogy a következő kapcsolási lépésben az aminocsoport hatékony nukleofilként vegyen részt a reakcióban.

A Fmoc/tBu kémiában használatos Fmoc-csoport eltávolítása egyszerüen, szekunder aminos kezeléssel megvalósítható. Erre a célra 5, majd 15 perces kezelés elegendő 20 (v/v\%) piperidin DMF-os oldatával.

A kapcsolási reakció gyorsítása, valamint a mellékreakciók elkerülése érdekében az $N$-terminuson védett aminosavat kapcsolás előtt aktiváljuk. Kapcsolószerként a legáltalánosabban diciklohexilkarbodiimidet (DCC) és szekunder nukleofilként hidroxibenztriazolt (HOBt) használtam, mindezeket az aminosavval együtt háromszoros fölöslegben adtam a gyantához. A peptidkötés kialakulásához 1-3 óra szükséges.

A szilárd fázisú peptidszintézis módszerének előnye, hogy sokszoros reagensfelesleg használatát teszi lehetővé így a reakciók nagy hatásfokkal játszódhatnak le. A kapcsolás, illetve a védőcsoport eltávolítás hatékonyságának ellenőrzése a Kaiser által kifejlesztett teszt a ninhidrin és a szabad aminocsoport közötti színreakción alapul [109]. Gyors, érzékeny és könnyen kivitelezhető módszer, 1\% szabad aminocsoport jelenlétét még észlelhető kék szín jelzi. Mivel a prolin nem amino-, hanem iminosav, nem képes a ninhidrinnel megfelelő színreakcióra, ezért esetében 2,3-indolin-diont (izatint) a Kaiser-féle reagensekhez adva specifikusan kimutatható a szekunder aminok jelenléte [110].

\subsubsection{Oldallánc védőcsoportok}

Az általam használt aminosavakat és az alkalmazott oldallánc-védőcsoportokat az 1. táblázat foglalja össze. Ezeken az aminosavakon kívül alanint, glicint, fenilalanint, izoleucint, leucint, metionint, prolint és valint használtam, melyek nem igényelnek oldalláncvédelmet. 


\subsubsection{A peptidek hasítása gyantáról}

Boc/Bzl stratégiánál a szilárd hordozóról való hasítás gyakran folyékony hidrogén fluoriddal (HF) történik $-5^{\circ} \mathrm{C}$-on. A hidrogén-fluoridos hasítás körülményei között jelentős karbokation képződés tapasztalható, ami alkilezheti vagy aralkilezheti a His, a Cys és egyéb aminosavak nukleofil oldalláncát. Ezek a mellékreakciók azonban megfelelő gyökfogókkal vagy az ún. „low-high” HF-os hasítási eljárással nagyrészt visszaszoríthatók [111]. Gyökfogóként általában anizolt, dimetil-szulfidot, p-krezolt, esetenként tiokrezolt használunk. A „low-high” módszer lényege, hogy a gyantán lévő peptidekről először a nagy moláris feleslegben alkalmazott gyökfogókkal, kis koncentrációjú HF-dal eltávolítják az oldallánc-védőcsoportok többségét, majd egy második lépésben nagy koncentrációban alkalmazott HF-dal hasítják le a peptidet a gyantáról a maradék védőcsoportokkal együtt. A hidrogénfluoridos hasítás után a nyers peptid éterrel kicsapható, így eltávolítható a gyökfogó nagy része, majd a gyantaszemcsék mellől ecetsav vizes oldatával kioldható.

$\mathrm{Az} F \operatorname{Fmoc} / \mathrm{Bu}$ stratégiánál nagy elöny, hogy a peptidek a gyantáról trifluorecetsavval hasíthatók, amely egyúttal a legtöbb védőcsoportot is eltávolítja a peptidről [112]. A TFA-as hasítás esetén is keletkezhetnek azonban elektrofil sajátságú melléktermékek (pl. $t$-butil kation), amelyek alkilezhetnek. Rendszerint 95 (v/v\%)-os vizes TFA-t használnak hasításra, melyet esetenként gyökfogókkal egészítenek ki, ilyenek a TIS, DTT, fenol. A peptidek hasítása a gyantáról általában már 2-3 óra alatt végbemegy. A nyers peptidet ebben az esetben is éteres kicsapással kaphatjuk meg.

\subsubsection{A peptidek tisztítása és azonosítása}

A szilárd fázisú peptidszintézissel készült peptideket célszerü HPLC-vel tisztítani, különösen ha a peptid gyantáról történő lehasításakor többféle gyökfogót alkalmazunk. A peptideket általában fordított fázisú C18 oszlopon, HPLC-vel tisztítják [113]. Hidrofób peptidek esetén a C8 oszlopok bizonyos esetekben jobb elválasztást biztosítanak. Leggyakrabban 0,05-0,1\% TFA-t tartalmazó eluensrendszert használnak, de különféle puffer-rendszerek is alkalmazhatóak. A jobb elválasztás érdekében célszerü gradienselúcióval tisztítani az anyagokat. Ez azt jelenti, hogy fokozatosan változtatjuk az oldószerösszetételt, növelve a szerves oldószer mennyiségét az eluensben. A 
detektáláshoz leggyakrabban az amidcsoportot használják kromofórként, 210-220 nm-nél vizsgálják az UV elnyelést.

A termék homogenitásának ellenőrzésére analitikai HPLC alkalmazható, azonosítása tömegspektrometriás méréssel történhet. A tömegspektrometria a relatív molekulatömeg meghatározásával bizonyítja a helyes szerkezetet, sőt fragmentációs eljárással bizonyos esetekben igazolható a szekvencia is. Peptidek esetében az ESI-MS technika a leginkább alkalmas módszer.

\subsection{Mikrohullámú peptidszintézis}

A szintézis kivitelezésére az új generációs CEM Discover SPS mikrohullámú szilárd fázisú szintézisek kivitelezésére alkalmas reaktort használjuk, amely számítógép segítségével össze van kötve a CEM Liberty reagens és oldószer tartó-adagoló résszel. A folyamat teljesen automatizált. A peptidszintézishez Fmoc/tBu stratégiát alkalmazunk.

A szintézishez általánosan $0.2 \mathrm{~mol} / \mathrm{dm}^{3}$ koncentrációban alkalmazzuk a Fmocaminosav-származékokat dimetilformamidban oldva. A kapcsolóreagens $0.5 \mathrm{~mol} / \mathrm{dm}^{3}$ HBTU vagy HATU és $0.5 \mathrm{~mol} / \mathrm{dm}^{3}$ HOBt vagy HOAt oldata dimetilformamidban. Az aktiváló bázis $2 \mathrm{~mol} / \mathrm{dm}^{3}$ DIEA oldata $N$-metil-pirrolidinben. A védett aminosavakat és a kapcsoló reagenseket általánosan négyszeres fölöslegben alkalmazzuk. A Fmoc-csoport hasításához itt is $20(\mathrm{v} / \mathrm{v} \%)$ piperidin/dimetilformamid elegyét használjuk.

A mikrohullámú peptidszintézisnek nincsen általános protokollja, reakcióparamétereinek (reakcióidő, magnetron teljesítmény, felfütési sebesség) optimális megválasztása kritikus lehet, akárcsak a szilárd hordozó hőmérséklet stabilitása.

A kész peptid gyantáról való hasítását manuálisan végezzük. Általánosan TFA/ $\mathrm{H}_{2} \mathrm{O} / \mathrm{DTT}$ 92:5:3 (v/v/m\%) elegyét használjuk 2-3 órás hasítási idő mellett. A nyers peptidet itt is éteres kicsapással nyerjük a hasítóelegyből.

\subsection{Peptidgerinc módosítást tartalmazó peptidomimetikumok előállítása}

A peptidgerinc módosítások közül itt csak a természetes aminosavak $D$ aminosavra történő cseréjét, az urea- és azafunkciót tartalmazó peptidek szintézisét tárgyalom, amelyeket felhasználtam az Ucn 3 analógok szintézisénél. 
A $D$-aminosavakat tartalmazó peptidek szintézise a hagyományos szilárd fázisú peptidszintézis előírásai szerint történik. Beépítésükre a megfelelően védett $D$ aminosavakat használjuk.

$\mathrm{Az}$ urea-peptidek szintézise szilárd fázison történhet kombinált Boc/Fmoc technikával, szilárd hordozóként MBHA hordozót használhatunk. A peptidláncot Bockémiával építjük ki mindaddig az aminosavig, amely $N$-terminálisán izocianátot szeretnénk kiépíteni. A gyantára kötött N-terminális Fmoc-védett aminosav egy lépésben alakul át izocianáttá $10 \mathrm{ekv}$. $\mathrm{MeSiCl}_{3}$ és $20 \mathrm{ekv}$. TEA jelenlétében. A reakció oldószere száraz diklórmetán. A keletkező izocianát-intermedier nem stabil, ezért in situ reagáltatjuk a megfelelő bázis $10(\mathrm{v} / \mathrm{v} \%)$-os oldatával diklórmetánban. A kész ureapeptidet a gyantáról folyékony hidrogén-fluoriddal hasíthatjuk le.

A N-en glutamin oldalláncot tartalmazó építőkövek szintézise aza-Michael addícióval történhet oldatban. Az addíció két partnere egy hidrazin-tartalmú vegyület vagy egy primer amin és akrilamid, a reakció oldószere $n$-propanol. A reagenseket ekvivalens mennyiségben használjuk, a reakcióelegyet $80-85^{\circ} \mathrm{C}$-on refluxáltatjuk 3 napig.

Az azaglutamint vagy $\mathrm{N}$-en glutamin oldalláncot tartalmazó peptidomimetikumok szintézise történhet Rink amid hordozón manuális Fmoc szilárd fázisú szintézissel vagy oldatfázisú szintézissel. Az aza-funkciót tartalmazó aminosavszármazékot szilárd hordozón a szabad N-terminális aminosav bis-(2,4-dinitrofenil)karbonáttal aktivált $\alpha$ aminocsoportjához kapcsoljuk, oldatfázisú szintézis esetén a vegyes anhidrides módszerrel kapcsolunk.

\subsection{Foszfotirozint és foszfoszerint tartalmazó peptidek előállítása}

Foszfotirozint ill. foszfoszerint tartalmazó peptidek szintézise szilárd fázison Fmoc-kémiával történik. A védett peptidláncot a tirozin vagy szerin oldallánc védőcsoport nélkül beépítéséig a szokásos módon végezzük.

A tirozin esetében a foszfatálás két lépésben zajlik: az első a foszfitilálás, majd ezt követi egy oxidációs lépés. A szabad tirozin oldallánccal rendelkező peptidet nagy fölöslegben (15-20 ekv.) di-terc-butil- $N, N$ '-dietilfoszforamidittel és $1 \mathrm{H}$-tetrazollal kezeljük vízmentes tetrahidrofuránban. A keletkező foszfit oxidálásához 14 (v/v\%)-os terc-butilhidroperoxid vizes oldatát használjuk. 
A szerin esetében is két lépésben történik a foszfatálás: az első a foszfonilálás, majd ezt követi egy oxidációs lépés. A szabad szerin oldallánccal rendelkező peptidhez nagy fölöslegben adunk terc-butil- $H$-foszfonátot (20 ekv.) és pivaloil-kloridot (40 ekv.) piridin:dimetilformamid 1:1 (v/v) elegyében. Az oxidációhoz $1(\mathrm{~m} / \mathrm{v} \%)$ jód tartalmú piridin:víz 8:2(v/v) elegyét használjuk.

Az $N$-terminális Fmoc-védőcsoport lehasításával folytatódhat a peptidlánc kiépítése. A peptid gyantáról való hasítása, kinyerése a hasítóelegyből a Fmoc-kémiánál megszokott módon történik.

\subsection{Biotinilálás szilárd fázison és oldatban}

A biotinilálás történhet oldatban vagy szilárd fázison, a módszert a peptid szekvenciája határozza meg. Amennyiben a peptid nem tartalmaz olyan aminosav

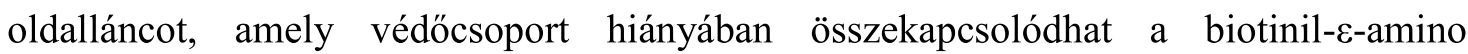
kapronsavval, a biotinilálást oldat fázisban végezzük biotinil-e-amino-kapronsav $N$ hidroxiszukcinimid aktív észtert használva.

Szilárd fázison a gyantára kötött peptid szabad $N$-terminális $\alpha$-aminocsoportjához kapcsoltam a biotinil-e-amino kapronsavat 3 ekv. mennyiségben használva 3-3 ekv. DCC és HOBt jelenlétében. A kapcsolást ninhidrin-próbával ellenőrizzük.

Oldat fázisban a biotiniláláshoz a peptidet kis térfogat dimetilformamidban oldjuk, kevés vizet adunk hozzá, az oldat pH-ját 8-9-re állítjuk DIEA hozzáadásával és így adunk hozzá 1.5-2 ekv. biotinil-e-amino-kapronsav $N$-hidroxiszukcinimid aktív észtert. A reakciót analitikai RP-HPLC-n követjük és ESI-MS-el ellenőrizzük. 


\section{Kísérleti rész}

\subsection{Antidepresszáns és anxiolitikus hatású Ucn 3 fragmensek és analógok előállítása}

Az Ucn 3, valamint ezen szekvencia fragmensei és 2-10 analógjai MBHA hordozón (0.5 mmol; borítottság: $1.03 \mathrm{mmol} / \mathrm{g})$ készültek manuális szilárd fázisú Boc/Bzl kémiával. A hordozó DCM-ban $(10 \mathrm{ml})$ való előduzzasztása után semlegesítettem TEA/DCM oldattal $(2 \times 10 \mathrm{ml}, 10 \mathrm{v} / \mathrm{v} \%)$, majd DCM-nal, MeOH-lal és újból DCM-nal (3x10-10 ml) mostam. A kapcsolásokhoz a hordozó kapacitásához számolt 3-3 ekv. mennyiségü Boc-védett aminosavat és DCC-t alkalmaztam. Arg, Asn és Gln esetében a kapcsoláshoz még 3 ekv. HOBt-t is adtam. A védett aminosav oldhatóságának függvényében oldószerként DCM-t $(10 \mathrm{ml})$ vagy DMF-t $(10 \mathrm{ml})$ alkalmaztam. A kapcsolási reakciókat kvalitatív ninhidrin- vagy izatin teszttel ellenőriztem. Negatív színreakció után lehasítottam a Boc-védőcsoportot TFA/DCM oldatával (10 ml, 50 v/v\%) 5+25 percig. A nyers peptid hasítása a szilárd hordozóról folyékony HF-dal $(20 \mathrm{ml})$ történt, gyökfogóként anizolt $(0.4 \mathrm{ml})$, dimetil-szulfidot $(1.6 \mathrm{ml})$ és $p$-krezolt $(0.4 \mathrm{ml})$ használtam. Hasítás után, az éterrel kicsapott peptidet szürtem, dietil-éterrel $(3 \times 50 \mathrm{ml})$ átmostam, majd leoldottam a szürőről ecetsav vizes oldatával $(100 \mathrm{ml}, 10 \mathrm{v} / \mathrm{v} \%)$. Ezt követte az oldat liofilizálása. A nyers peptideket szemipreparatív RP-HPLC-n tisztítottam. Ezen peptidek előállítása 80-85\%-os kitermeléssel valósult meg.

Az 5 analóg szintézise annyiban tér el az előzőekben leírtaktól, hogy a peptid $N$ terminális aminosaváról lehasítottam a Boc-védőcsoportot, majd a polimert ecetsavanhidrid/DCM eleggyel $(10 \mathrm{ml}, 30 \mathrm{v} / \mathrm{v} \%)$ kezeltem $5+25$ percig, ezt követte a mosási lépés (DCM, MeOH). Az acetilezési reakció hatékonyságát szintén ninhidrinpróbával ellenőriztem. A peptid gyantáról való lehasítása az előzőekben leírtak szerint történt. Az 5 analógot 85\%-os kitermeléssel állítottam elő.

Az 1 analóg előállítása Merrifield polimeren $(0.5 \mathrm{mmol}$, borítottság: $1.1 \mathrm{mmol} / \mathrm{g})$ történt. A $C$-terminális aminosav kapcsolásához előduzzasztottam a hordozót DMF-ban ( $5 \mathrm{ml}$ ), majd hozzáadtam 2 ekv. Boc-védett aminosavat és 4 ekv. KF-ot, amit előzőleg feloldottam DMF-ban $(5 \mathrm{ml})$ és $70^{\circ} \mathrm{C}$-on, 48 órán át kevertettem. A kapcsolási reakció után mostam a hordozót DMF-dal, MeOH-lal, vízzel, majd újból MeOH-lal, DCM-nal 
(3x10-10 ml). A peptidlánc továbbépítése a Boc-védőcsoport hasításával, a gyanta semlegesítésével folytatódik. A további aminosavak kapcsolása, a peptid hordozóról való hasítása az előzőekben leírtak szerint történt. A kitermelés 87\%-os volt.

A 11-13 analógok szintézise oldatfázisban történt. Feloldottam Boc-védett Gln-t (3.08 mmol) etil-acetátban $(45 \mathrm{ml})$, hozzáadtam 1.1 ekv. klórhangyasav-izobutilésztert, valamint ekv. mennyiségü DIEA-t és kevertettem $-15^{\circ} \mathrm{C}$-on 15 percig. Ezután $0^{\circ} \mathrm{C}$-on hozzácsepegtettem 1.1 ekv. izobutilamint és további 2 órán keresztül kevertettem. A reakcióelegy térfogatát etil-acetát $(45 \mathrm{ml})$ hozzáadásával megdupláztam, majd átráztam $\mathrm{KHSO}_{4}$-tal $(3 \times 50 \mathrm{ml}, 5 \mathrm{~m} / \mathrm{v} \%)$ és $\mathrm{KHCO}_{3}$-tal $(3 \times 50 \mathrm{ml}, 5 \mathrm{~m} / \mathrm{v} \%)$. A szerves fázist $\mathrm{Na}_{2} \mathrm{SO}_{4}$-tal szárítottam, szürtem a szárítószert, bepároltam az elegyet, majd a terméket éterrel kristályosítottam. A 12-13 analógok előállításához az előzőekben kapott Bocvédett termékről lehasítottam a Boc-védőcsoportot: TFA-val $(2 \mathrm{ml})$ kevertettem 30 percig, majd kicsaptam jéghideg éterrel a keletkezett terméket, a csapadékot szürtem, majd a szürőről leoldottam acetonitril-víz elegyével $(10 \mathrm{ml})$, liofilizáltam. A szárított terméket acetileztem: feloldottam acetonitrilben $(5 \mathrm{ml})$ és hozzácsepegtettem fölöslegben ecetsavanhidridet $(0.5 \mathrm{ml})$ és szobahőmérsékleten 1.5 óráig kevertettem. A reakció végén az oldatot vízzel hígítottam $(30 \mathrm{ml})$ és liofilizáltam. A kész termékeket kromatográfiásan tisztítottam. A 11-13 analógokat 70-86\%-os kitermeléssel állítottam elő.

A 14a-e urea-peptidek szintézise MBHA hordozón $(0.2 \mathrm{mmol}$, borítottság: 1.03 $\mathrm{mmol} / \mathrm{g}$ ) történt. A szintézis annyiban tér el az MBHA hordozónál használatos hagyományos Boc-protokolltól, hogy a Gln-t Fmoc-védetten építettem be és így használtam az izociánát kialakításához. A reakció előtt a hordozót vízmentes DCM-ban $(10 \mathrm{ml})$ előduzzasztottam, majd hozzácsepegtettem $20 \mathrm{ekv}$. TEA-t, $10 \mathrm{ekv}$. $\mathrm{MeSiCl}_{3}$-t. 24 óra után a reakcióelegyet szürtem és utána rögtön hozzáöntöttem a hordozóhoz a megfelelő bázis oldatát DCM-ban $(10 \mathrm{ml}, 10 \mathrm{v} / \mathrm{v} \%)$ és szobahőmérsékleten további 2 óráig kevertettem. A felhasznált bázisok: propilamin, izopropilamin, piperidin, piperazin, 1-fenil-piperazin voltak. Reakció után többszöri mosás következett DCM-nal, DMF-dal, acetonitrilel, DCM-nal (3x10-10 ml). A kész urea-peptideket folyékony HF-dal $(5 \mathrm{ml})$ hasítottam le $\left(-5^{\circ} \mathrm{C}, 45\right.$ perc $)$ és kromatográfiásan tisztítottam. A 14a-e peptidomimetikumok előállítását 55-60\%-os kitermeléssel sikerült megvalósítani. 
A 15a-c, valamint 16 peptidomimetikumok szintéziséhez előzetesen előállítottam a 17, 18, 20 építőköveket aza-Michael addícióval.

A 17-18 építőkövek szintéziséhez feloldottam n-propanolban $(150 \mathrm{ml})$ ekv. mennyiségü (3-3 mol) n-butilamint, illetve Boc-hidrazidot, valamint akrilamidot és 82$85^{\circ} \mathrm{C}$-on refluxáltattam 3 napig. A reakciót vékonyrétegen követtem hexán-etilacetátmetanol elegyében (5:4:1). A reakcióidő eltelte után szürtem az elegyet, bepároltam és kicsaptam éterrel a 3-butil-amino-propánamid (17), illetve a 3-(N'-terc-butoxikarbonilhidrazino)propánamid (18) kristályokat. A 17-18 építőkövek szintézise 47-75\%-os kitermeléssel valósult meg.

A 20 építőkő szintéziséhez feloldottam a Boc- $L-\mathrm{Ala}-\mathrm{OH}-\mathrm{t}$ (3 mol) etil-acetátban (50 ml), hozzáadtam 1.1 ekv. klórhangyasav-izobutil-észtert és ekv. mennyiségü DIEA-t és kevertettem $-15^{\circ} \mathrm{C}$-on 15 percig, majd $0^{\circ} \mathrm{C}$-on hozzácsepegtettem $1.1 \mathrm{ekv}$. hidrazinhidrátot és további 2 órán át kevertettem. A reakcióelegy térfogatát etil-acetát $(50 \mathrm{ml})$ hozzáadásával megdupláztam, majd átráztam $\mathrm{KHSO}_{4}$-tal $(3 \times 100 \mathrm{ml}, 5 \mathrm{~m} / \mathrm{v} \%), \mathrm{KHCO}_{3}$ tal $(3 \times 100 \mathrm{ml}, 5 \mathrm{~m} / \mathrm{v} \%)$. A szerves fázist $\mathrm{Na}_{2} \mathrm{SO}_{4}$-tal szárítottam, a szárítószert szürtem, az elegyet bepároltam, majd a terméket éterrel kristályosítottam. A kapott Boc- $L$-Alahidrazidot (19) ekv. mennyiségű akrilamiddal reagáltattam 3 napig $n$-propanolban (150 $\mathrm{ml}), 82-85^{\circ} \mathrm{C}$-on refluxáltatva az elegyet. A reakciót vékonyrétegen követtem hexánetilacetát-metanol elegyében (5:4:1). A reakcióidő eltelte után szürtem az elegyet, bepároltam és kicsaptam éterrel a 3-[( $N^{\prime}$-terc-butoxikarbonil- $L$-alanil)hidrazin $]$ propánamid (20) kristályokat. A 20 építőkövet 32\%-os kitermeléssel állítottam elő.

A 15a-c peptidomimetikumok szintézise Rink polimeren $(0.5 \mathrm{mmol}$, borítottság: $0.72 \mathrm{mmol} / \mathrm{g})$ történt. A hordozót DMF-ban $(10 \mathrm{ml})$ előduzzasztottam és lehasítottam a Fmoc-védőcsoportot pireridin/DMF elegyével $(10 \mathrm{ml}, 20 \mathrm{v} / \mathrm{v} \%) 5+20$ percig, majd kapcsoltam a $C$-terminális aminosavat: 3 -3 ekv. Fmoc- $L$-Ile-OH-t és DCC-vel. A Fmocvédőcsoport eltávolítása után, átmostam a hordozót többször száraz DMF-dal (10-10 ml), majd hozzáadtam 5 ekv. bis(2,4-dinitrofenil)karbonátot (21) amit előzőleg száraz DMFban $(5 \mathrm{ml})$ oldottam és hozzácsepegtettem $5 \mathrm{ekv}$. $N$-metilmorfolint. A reakciót 24 órán át kevertettem, sikerességét Kaiser-teszttel ellenőriztem. Negatív teszteredmény után a gyantához adtam 3 ekv. szekunder amint, illetve a N-en Gln oldalláncot tartalmazó építőkövet $(\mathbf{1 7}, \mathbf{1 8}, \mathbf{2 0})$, amit előzőleg DMF-ban $(10 \mathrm{ml})$ oldottam. 24 óra után többször 
mostam a hordozót: DCM-nal, DMF-dal, acetonitrillel, DCM-nal, végül MeOH-lal (10$10 \mathrm{ml})$. A peptidomimetikumokat a gyantáról TFA/víz elegyével $(5 \mathrm{ml}, 90 \mathrm{v} / \mathrm{v} \%)$ hasítottam le. A szürt reakcióelegyet vízzel $(50 \mathrm{ml})$ hígítottam, liofilizáltam. A nyers termékeket szemipreparatív RP-HPLC-n tisztítottam. A 15a-c analógok kitermelése 20$40 \%$-os volt.

A bis(2,4-dinitrofenil)karbonát (21) szintéziséhez konc. $\mathrm{HNO}_{3}(50 \mathrm{ml})$ és konc. $\mathrm{H}_{2} \mathrm{SO}_{4}(60 \mathrm{ml})$ elegyéhez $50-55^{\circ} \mathrm{C}$-on nagyon lassan hozzáadtam difenil-karbonátot (10 g) és még további 3 óráig $50^{\circ} \mathrm{C}$-on, majd 90 óráig szobahőmérsékleten kevertem a reakciót. Ezután az elegyet nagy mennyiségü jeges vízre öntöttem, és a reakcióelegyből kiváló csapadékot addig mostam jeges vízzel amíg a leszürődő oldat $\mathrm{pH}$-ja semleges nem lett. A keletkező viszkózus terméket $\mathrm{P}_{2} \mathrm{O}_{5}$-on szárítottam, majd újra kristályosítottam hexán-benzol elegyében. A termék olvadáspontja: $146^{\circ} \mathrm{C}$; kitermelés: $69 \%$.

A 16 analóg szintéziséhez a 18 építőkő $(2 \mathrm{mmol})$ kis részletét feloldottam DMFban $(4 \mathrm{ml})$ és hozzácsepegtettem 1 ekv. TEA-t és 1.1 ekv. KHIBE-t $-15^{\circ} \mathrm{C}$-on, majd $0^{\circ} \mathrm{C}$ on kevertettem 2 óráig. A reakcióidő lejárta után bepároltam az elegyet, majd etilacetátban $(30 \mathrm{ml})$ oldottam és átráztam $\mathrm{NaHSO}_{4}$-tal $(3 \times 10 \mathrm{ml}, 5 \mathrm{~m} / \mathrm{v} \%)$ és $\mathrm{NaHCO}_{3}$-tal ( $3 \times 10 \mathrm{ml}, 5 \mathrm{~m} / \mathrm{v} \%)$. A szerves fázist $\mathrm{Na}_{2} \mathrm{SO}_{4}$-tal szárítottam, szürtem a szárítószert és bepároltam az elegyet. A nyers terméket szemipreparatív RP-HPLC-n tisztítottam. A 16 analóg kitermelése $85 \%$-os volt.

Az Ucn 3-t, valamint fragmenseit és analógjait analitikailag jellemeztem retenciós idejük és molekulatömegük alapján (ld. 4., 5., 6., 7. tábl.).

\subsection{Az orexin A előállítása}

A lineáris orexin A $\left(<\right.$ EPLPDCCRQKTCSCRLYELLHGAGNHAAGILTL-NH $\left.{ }_{2}\right)$ szintézise Rink amid-ChemMatrix ${ }^{\circledR}$ hordozón történt $(0.5 \mathrm{mmol}$, borítottság: 0.46 mmol/g) CEM mikrohullámú szintetizátor segítségével. A peptidlánc felépítéséhez használt aminosavak: Fmoc- $L-\mathrm{Ala}-\mathrm{OH}$, Fmoc- $L-\mathrm{Asn}(\mathrm{Trt})-\mathrm{OH}$, Fmoc- $L-\mathrm{Asp}(\mathrm{O} t \mathrm{Bu})-\mathrm{OH}$, Fmoc- $L$-Arg(Pbf)-OH, Fmoc- $L-\mathrm{Cys}(\mathrm{Trt})-\mathrm{OH}$, Fmoc- $L-\mathrm{Gly}-\mathrm{OH}$, Fmoc- $L-\mathrm{G} \ln (\mathrm{Trt})-\mathrm{OH}$, Glp-OH, Fmoc- $L-\mathrm{Glu}(\mathrm{O} t \mathrm{Bu})-\mathrm{OH}$, Fmoc- $L$-His(Trt)-OH, Fmoc- $L-\mathrm{Ile}-\mathrm{OH}$, Fmoc- $L$-Leu$\mathrm{OH}$, Fmoc- $L$-Lys(Boc)-OH, , Fmoc- $L-\operatorname{Ser}(t \mathrm{Bu})-\mathrm{OH}$, Fmoc- $L$-Pro-OH, Fmoc- $L$-Thr( $t \mathrm{Bu})$ $\mathrm{OH}$, Fmoc- $L-\operatorname{Tyr}(t \mathrm{Bu})-\mathrm{OH}$. Az $N$-terminális aminosav pGlu, amelyet védőcsoport nélkül építettem be. Az aminosavak kapcsolásához HATU és HOAt elegyét használtam DIEA 
jelenlétében. A kapcsolószereket a védett aminosav-származékokkal együtt négyszeres fölöslegben használtam. A gyantáról TFA/víz/DTT/TIS 83:10:5:2 (v/v/m/v\%) arányú elegyével $(10 \mathrm{ml}) 3$ óra alatt lehasított peptidről lepároltam a TFA-t és jéghideg éterrel kicsaptam a terméket, szürtem, átmostam dietil-éterrel (3x $30 \mathrm{ml})$, majd leoldottam a szürőről a peptidet ecetsav-víz elegyével $(50 \mathrm{ml}, 10 \mathrm{v} / \mathrm{v} \%)$ és az oldatot liofilizáltam.

Az optimalizált CEM protokollt a 25. táblázat foglalja össze.

25. táblázat: Az optimalizált CEM protokoll

\begin{tabular}{|c|c|c|c|c|c|}
\hline CEM Protokoll & $\begin{array}{c}\text { Lépés } \\
\text { módja }\end{array}$ & $\begin{array}{c}\text { Lépések } \\
\text { száma }\end{array}$ & $\begin{array}{c}\text { Magnetron } \\
\text { teljesítmény }(\mathbf{W})\end{array}$ & $\begin{array}{c}\text { Max. } \\
\text { hőmérséklet }\left({ }^{\circ} \mathbf{C}\right)\end{array}$ & $\begin{array}{c}\text { Reakcióidó } \\
\text { (sec) }\end{array}$ \\
\hline Fmoc-hasítás & ismételt & 1 & 35 & 75 & 30 \\
\hline Ált. kapcsolás & egyszeri & 1 & 40 & 75 & 600 \\
\hline Cys, His & \multirow{2}{*}{ egyszeri } & 2 & 26 & 35 & 1800 \\
\hline Arg kapcsolása & & 0 & 15 & 35 & 2400 \\
\hline
\end{tabular}

Az oxidációs optimalizálásához a lineáris nyers peptid kis részleteit használtam az alábbiakban leírt reakciókban, az oxidációt analitikai RP-HPLC-n követtem, az oszlopról eluálódó frakciókat tömegspektrometriával ellenőriztem:

a. a nyers lineáris peptidet $(2.5 \mathrm{mg})$ feloldottam vízben $(5.0 \mathrm{ml})$ és az oldat keverése közben hozzácsepegtettem jód/aceton-t $(1 \mathrm{~m} / \mathrm{v} \%)$ mindaddig amíg az oldat el nem színeződött.

b. a lineáris nyers peptidet $(2.5 \mathrm{mg})$ feloldottam glikokoll-NaOH pufferben $(2.5 \mathrm{ml}, \mathrm{pH}$ 8.9) és levegőn 24 órán át kevertettem.

c. a lineáris nyers peptidet $(2.5 \mathrm{mg})$ DMSO-t tartalmazó ammónium-acetát puffer-ben ( 2.5 ml, 10 v/v\%; pH 6.5) 2 órán keresztül kevertettem.

d. a lineáris nyers peptidet $(2.5 \mathrm{mg})$ Tris- $\mathrm{HCl}$ pufferben $(2.5 \mathrm{ml}, \mathrm{pH} 8.4)$ oldottam, hozzáadtam a cisztein/cisztin keverékét ( $4 \mathrm{mM} / 2 \mathrm{mM})$ és 5 percen át kevertettem.

e. a lineáris nyers peptidet $(5.0 \mathrm{mg})$ ammónium-acetát puffer ( $\mathrm{pH} 7.5)$ :acetonitril 1:1 $(\mathrm{v} / \mathrm{v})$ elegyében $(5 \mathrm{ml})$ oldottam, hozzáadtam Clear-ox ${ }^{\mathrm{TM}}$ gyantát $(95 \mathrm{mg}$, borítottság: 0.18 mmol/g), amelyet előzőleg 30 percig DCM-ban ( $5 \mathrm{ml}$ ) duzzasztottam, DMF-dal, $\mathrm{MeOH}$ lal és acetonitril/víz-zel (1:1) mostam (5-5 ml). Az oxidációs reakció lejátszódását jelezte 
a gyanta színének változása is élénk sárgáról mély narancssárgára. A reakcióelegyet két óra után szürtem, mostam acetonitril:víz 1:1 (v/v) elegyével. A szürletről vákuum alatt lepároltam az acetonitril többségét, hígítottam vízzel és liofilizáltam.

A termék azonosítása a kereskedelemben kapható orexin A-val történő kromatográfiás összehasonlítás révén történt. A ciklizált termék nagyobb mennyiségü előállításához szemipreparatív RP-HPLC-n tisztítottam a nyers lineáris termék 200 mg-os részletét és a legoptimálisabbnak ítélt módszerrel ciklizáltam.

Feloldottam a tisztított lineáris peptidet (25 mmol) $\mathrm{NH}_{4} \mathrm{OAc}$ puffer ( $\mathrm{pH}$ 7.5):acetonitril $3: 1(\mathrm{v} / \mathrm{v})$ elegyében $(100 \mathrm{ml})$ és hozzáadtam $12 \mathrm{x}$-es fölöslegben Clear-ox ${ }^{\mathrm{TM}}$ gyantát (borítottság: $0.21 \mathrm{mM} / \mathrm{g})$, amelyet előzőleg 30 percig duzzasztottam DCM-ban $(15 \mathrm{ml})$, mostam DMF-dal, MeOH-lal és acetonitril/víz 1:1 (v/v) elegyével (15-15 ml). Két óra után szürtem a reakcióelegyet, a hordozót mostam acetonitril/víz-zel (1:1), vákuum alatt lepároltam az acetonitril többségét, az oldatot vízzel kihígítottam és liofilizáltam. A nyers ciklizált terméket szemipreparatív RP-HPLC-n tisztítottam és analitikailag jellemeztem (ld. 8. tábl.). Az orexin A-t 72\%-os kitermeléssel állítottam elö.

\subsection{Az anuroctoxin előállítása}

A lineáris peptid (<EKECTGPQHCTNFCRKNKCTHGKCMNRKCKCFNCK$\mathrm{OH})$ előállítása Boc-Lys(2ClZ)-PAM hordozón történt $(0.5 \mathrm{mmol}$, borítottság: 0.6 $\mathrm{mmol} / \mathrm{g}$ ) az általános szintézismódszerben leírt manuális Boc-SPPS protokoll szerint. A peptidlánc felépítéséhez használt aminosavak: Boc- $L-A s n-O H$, Boc- $L-\operatorname{Arg}(T o s)-$ $\mathrm{OH} \cdot \mathrm{EtOAc}$, Boc- $L-\mathrm{Cys}(\mathrm{Meb})-\mathrm{OH}$, Boc- $L-\mathrm{Gly}-\mathrm{OH}$, Boc- $L-\mathrm{Gln}-\mathrm{OH}$, Boc- $L-\mathrm{Glu}(\mathrm{OcHx})-$ $\mathrm{OH}$, Boc- $L$-Lys(2ClZ)-OH, Boc- $L-\mathrm{His}(\mathrm{Z})-\mathrm{OH}$, Boc- $L-\mathrm{Met}-\mathrm{OH}$, Boc- $L-\mathrm{Phe}-\mathrm{OH}$, Boc- $L-$ Pro-OH, Boc- $L$-Thr(Bzl)-OH. Az $N$-terminális pGlu-t védőcsoport nélkül építettem be. A peptidet anizolt $(0.4 \mathrm{ml})$, dimetil-szulfidot $(1.6 \mathrm{ml}), p$-krezolt $(0.4 \mathrm{ml})$ és DTT-t $(200 \mathrm{mg})$ tartalmazó folyékony HF-dal $(20 \mathrm{ml})$ hasítottam le a hordozóról $-5^{\circ} \mathrm{C}$-on 60 perc alatt. Hasítás után a hordozóra éterrel kicsapott peptidet szürtem, mostam dietil-éterrel és leoldottam a szürőről ecetsav vizes oldatával (10 v/v\%), ezt liofilízáltam.

A ciklizálási kísérletek optimalizálásához a nyers lineáris peptid kis részleteit használtam. A reakciót analitikai RP-HPLC-n követtem, az eluálódó frakciókat tömegspektrometriával ellenőriztem: 
a. a lineáris peptidet $(5 \mathrm{mg})$ glikokoll- $\mathrm{NaOH}$ pufferben $(10 \mathrm{ml}, \mathrm{pH} 8.7)$ oldottam és 24 órán át kevertettem.

b. a lineáris peptidet $(2 \mathrm{mg})$ ammónium-acetát pufferben $(2 \mathrm{ml}, \mathrm{pH} 6.5)$ kevertettem, DMSO-t (10 v/v\%) adtam hozzá, majd 3 órán keresztül kevertettem.

c. a lineáris peptidet ( $2 \mathrm{mg})$ Tris- $\mathrm{HCl}$ pufferben $(2 \mathrm{ml}, \mathrm{pH} 8.4)$ oldottam, beleszórtam a cisztein/cisztin (4 mM/2 mM) keverékét és 1 órán át kevertettem.

A ciklizált termék izolálásához a nyers lineáris peptid $(20 \mathrm{mmol})$ kis mennyiségét oxidáltam az $a$. pontban leírtak szerint és szemipreparatív RP-HPLC-n tisztítottam. A tiszta peptid toxin analitikai paramétereit a 9. táblázat foglalja össze (ld. 3.3.1. fejezet). Az anuroctoxin elóállítása 68\%-os kitermeléssel valósult meg.

\subsection{Anuroctoxin analógok előállítása}

Az előállított anuroctoxin analógokat a 11. táblázat foglalja össze.

Az analógok mindegyike TentaGel R PHB polimeren ( $0.25 \mathrm{mmol}$, borítottság: 0.2 mmol/g) készült CEM mikrohullámú szintetizátorral. A peptidlánc felépítéséhez használt aminosavak: Fmoc- $L$-Asn(Trt)-OH, Fmoc- $L$-Arg(Pbf)-OH, Fmoc- $L$-Cys(Trt)-OH, Fmoc$L$-Gly-OH， Fmoc-L-Gln(Trt)-OH， Fmoc- $L-\mathrm{Glu}(\mathrm{O} t \mathrm{Bu})-\mathrm{OH}, \quad$ Fmoc- $L$-Lys(Boc)-OH, Fmoc- $L$-His-OH, Fmoc- $L-M e t-O H, \quad F m o c-L-P h e-O H, \quad F m o c-L-P r o-O H, \quad F m o c-L-$ $\operatorname{Thr}(t \mathrm{Bu})-\mathrm{OH}$. Az $N$-terminális pGlu védőcsoport nélkül került beépítésre. Az aminosavak kapcsolásához HBTU, HOBt elegyét használtam DIEA jelenlétében. A kapcsolószereket a védett aminosav-származékokkal együtt négyszeres fölöslegben használtam. A peptideket TFA/víz/DTT/TIS 83:10:5:2 (v/v/m/v\%) arányú elegyével $(10 \mathrm{ml}) 3$ óra alatt hasítottam le a szilárd hordozóról. A TFA-t lepároltam és jéghideg éterrel kicsaptam a terméket, szürtem, dietil-éterrel mostam a polimert, majd leoldottam a szürőről a peptidet ecetsav-víz elegyével ( $10 \mathrm{v} / \mathrm{v} \%)$ és az oldatot liofilizáltam.

Az optimalizált CEM protokollt a 26. táblázat foglalja össze. 
26. táblázat: Az optimalizált CEM protokoll

\begin{tabular}{|c|c|c|c|c|c|}
\hline CEM Protokoll & $\begin{array}{l}\text { Lépés } \\
\text { módja }\end{array}$ & $\begin{array}{c}\text { Lépések } \\
\text { száma }\end{array}$ & $\begin{array}{c}\text { Magnetron } \\
\text { teljesítmény }(W)\end{array}$ & $\begin{array}{c}\text { Max. } \\
\text { hőmérséklet }\left({ }^{\circ} \mathrm{C}\right)\end{array}$ & $\begin{array}{c}\text { Reakcióidő } \\
\text { (sec) }\end{array}$ \\
\hline \multirow{2}{*}{ Fmoc-hasítás } & \multirow{2}{*}{ ismételt } & 1 & 35 & 75 & 30 \\
\hline & & 1 & 40 & 75 & 180 \\
\hline Ált. kapcsolás & egyszeri & 1 & 26 & 75 & 300 \\
\hline \multirow{2}{*}{$\begin{array}{c}\text { Cys, Hys } \\
\text { kapcsolása }\end{array}$} & \multirow{2}{*}{ dupla } & \multirow{2}{*}{2} & 0 & 50 & 120 \\
\hline & & & 25 & 50 & 240 \\
\hline \multirow{2}{*}{ Arg kapcsolása } & \multirow{2}{*}{ dupla } & \multirow{2}{*}{2} & 0 & 75 & 1500 \\
\hline & & & 25 & 75 & 30 \\
\hline
\end{tabular}

Az analógok oxidálása az anurotoxinnál is használt módszerrel történt: a lineáris peptidet glikokoll-NaOH ( $\mathrm{pH}$ 8.7) pufferben oldottam és levegőn 24 órán át kevertettem. A ciklizált nyers termékeket szemipreparatív HPLC-n tisztítottam és analitikailag jellemeztem (ld. 12. tábl. 3.3.2. fejezet). Az anuroctoxin analógok kitermelése 54-62\%-os volt.

\subsection{Tc32 izomerek előállítása}

5.5.1. „Oxidatív folding” kísérletek

A lineáris Tc32 (TGPQTTCQAAMCEAGCKGLGKSMESCQGDTCKCKA-OH) szintézise Boc-Ala-PAM hordozón történt $(0.5 \mathrm{mmol}$, borítottság: $0.5 \mathrm{mmol} / \mathrm{g})$ az általános szintézismódszerben leírt manuális Boc-SPPS protokoll szerint. A peptidlánc felépítéséhez használt aminosavak: Boc- $L-\mathrm{Ala}-\mathrm{OH}$, Boc- $L-\mathrm{Asp}(\mathrm{OcHx})-\mathrm{OH}$, Boc- $L-$ Cys(Meb)-OH，Boc- $L-G l y-O H ， B o c-L-G l n-O H ， B o c-L-G l u(O c H x)-O H ， B o c-L-L e u-$ $\mathrm{OH} \cdot \mathrm{H}_{2} \mathrm{O}$, Boc- $L$-Lys(2ClZ)-OH, Boc- $L-\mathrm{Met}-\mathrm{OH}$, Boc- $L$-Ser(Bzl)-OH, Boc- $L$-Pro-OH, Boc- $L-\operatorname{Thr}(\mathrm{Bzl})-\mathrm{OH}$. A peptidet a gyantáról anizolt $(0.4 \mathrm{ml})$, dimetil-szulfidot $(1.6 \mathrm{ml}), p$ krezolt $(0.4 \mathrm{ml})$ és DTT-t $(200 \mathrm{mg})$ tartalmazó folyékony HF-dal $(20 \mathrm{ml})$ hasítottam le $5^{\circ} \mathrm{C}$-on 45 perc alatt. Hasítás után, a gyantára kicsapott peptidet szürtem, átmostam dietiléterrel, majd leoldottam a szürőről ecetsav vizes oldatával (10 v/v\%). Ezt követte az oldat liofilizálása.

A ciklizálási kísérletek optimalizálásához a nyers lineáris peptid kis részleteit használtam. A reakciót analitikai RP-HPLC-n követtem, az eluálódó frakciókat tömegspektrometriával ellenőriztem: 
a. a lineáris peptidet $(5 \mathrm{mg})$ feloldottam vízben $(10 \mathrm{ml})$ és 24 órán át levegőn kevertettem.

b. a lineáris peptidet $(5 \mathrm{mg})$ feloldottam glikokoll-NaOH pufferben $(10 \mathrm{ml}, \mathrm{pH}$ 8.7) és 24 órán keresztül kevertettem.

c. a lineáris peptidet $(5 \mathrm{mg})$ feloldottam glikokoll-NaOH $(10 \mathrm{ml}, \mathrm{pH} 9.5)$ pufferben és 24 órán át kevertettem.

d. a lineáris peptidet $(5 \mathrm{mg})$ glikokoll-NaOH pufferben $(10 \mathrm{ml}, \mathrm{pH} 10)$ oldottam és 24 órán át kevertettem.

e. a lineáris peptidet $(2 \mathrm{mg})$ feloldottam ecetsav-oldatban $(2 \mathrm{ml}, \mathrm{pH} 2.7)$ és 48 órán át levegőn kevertettem.

f. a lineáris peptidet ( $2 \mathrm{mg})$ ecetsav-oldatban ( $2 \mathrm{ml}, \mathrm{pH} 2.7)$ oldottam és DMSO-t (10 (v/v\%) adtam az elegyhez, így kevertettem 48 órán át.

g. a lineáris peptidet $(2 \mathrm{mg})$ ecetsav-oldatban $(2 \mathrm{ml}, \mathrm{pH} 2.7)$ oldottam és Clear-ox $^{\mathrm{TM}}$ gyantát (75 mg, borítottság: $0.21 \mathrm{mmol} / \mathrm{g}$ ) adtam hozzá, majd 48 órán keresztül kevertettem.

h. a lineáris peptidet $(2 \mathrm{mg})$ foszfát pufferben $(2 \mathrm{ml}, \mathrm{pH}$ 6.5) kevertettem levegőn 48 órán keresztül.

$i$. a lineáris peptidet $(2 \mathrm{mg})$ ammónium-acetát pufferben $(2 \mathrm{ml}, \mathrm{pH}$ 6.5) kevertettem és DMSO-t (10 v/v\%) adtam az elegyhez majd 4 órán át kevertettem.

$j$. a lineáris peptidet $(2 \mathrm{mg})$ feloldottam ammónium-acetát pufferben $(2 \mathrm{ml}, \mathrm{pH} 6.5)$ és Clear-ox ${ }^{\mathrm{TM}}$ gyantát $(75 \mathrm{mg}$, borítottság: $0.21 \mathrm{mmol} / \mathrm{g})$ adtam hozzá, majd 2 órán át kevertettem.

$k$. a lineáris peptidet $(2 \mathrm{mg})$ ammónium-acetát pufferben $(2 \mathrm{ml}, \mathrm{pH} 7.5)$ levegőn 24 óráig kevertettem.

l. a lineáris peptidet $(2 \mathrm{mg})$ ammónium-acetát puffer (pH 7.5): acetonitril 1:1 (v/v) arányú elegyében $(2 \mathrm{ml})$ oldottam, Clear-ox ${ }^{\mathrm{TM}}$ gyantát $(75 \mathrm{mg}$, borítottság: $0.21 \mathrm{mmol} / \mathrm{g})$ adtam hozzá és 2 órán keresztül kevertettem.

$m$. a lineáris peptidet $(2 \mathrm{mg})$ feloldottam ammónium-acetát pufferben $(2 \mathrm{ml}, \mathrm{pH} 7.5)$, hozzáadtam guanidin-hidrokloridot $\left(8 \mathrm{~mol} / \mathrm{dm}^{3}\right)$ és Clear-ox ${ }^{\text {TM }}$ gyantát $(75 \mathrm{mg}$, borítottság: $0.21 \mathrm{mmol} / \mathrm{g}$ ), majd 24 órán át kevertettem. 
n. a lineáris peptidet $(2 \mathrm{mg})$ Tris- $\mathrm{HCl}$ pufferben $(2 \mathrm{ml}, \mathrm{pH} 8.4)$ kevertettem levegőn 24 órán keresztül.

$o$. a lineáris peptidet $(2 \mathrm{mg})$ Tris- $\mathrm{HCl}$ pufferben $(2 \mathrm{ml}, \mathrm{pH} 8.4)$ oldottam, beleszórtam a cisztein/cisztin $(4.5 \mathrm{mM} / 0.45 \mathrm{mM})$ keverékét és 5 percen át kevertettem.

p. a lineáris peptidet $(2 \mathrm{mg})$ Tris- $\mathrm{HCl}$ pufferben $(2 \mathrm{ml}, \mathrm{pH} 8.4)$ oldottam, beleszórtam cisztein/cisztin ( $4 \mathrm{mM} / 2 \mathrm{mM})$ arányú keverékét és 5 percen át kevertettem.

A $a$.-d. pontok egyesített oxidált nyers termékeinek a tisztítása során izoláltam az első Tc32 izomert: Tc32 I. A Tc32 I kitermelése 75\%-os volt.

A második Tc32 izomert (Tc32 II) az $l$. pontban leírtak szerint állítottam elő: a lineáris nyers peptidet $(12 \mathrm{mmol})$ ammónium-acetát puffer $(\mathrm{pH} 7.5)$ : acetonitril 1:1 arányú elegyében $(10 \mathrm{ml})$ oldottam és $12 \mathrm{ekv}$. Clear-ox ${ }^{\mathrm{TM}}$ gyantát (borítottság: $0.21 \mathrm{mmol} / \mathrm{g}$ ) adtam hozzá, amelyet előzőleg 30 percig DCM-ban $(10 \mathrm{ml})$ duzzasztottam, mostam DCM-nal, DMF-dal, MeOH-lal és acetonitril:víz elegyével $(10-10 \mathrm{ml}) .2$ óra után szürtem az elegyet, átmostam a gyantát egy kis térfogat acetonitril:víz-zel (1:1), vákuum alatt az acetonitril nagy részét lepároltam, vízzel kihígítottam és liofilizáltam. A nyers peptidet kromatográfiásan tisztítottam és analitikailag jellemeztem (ld. 14. tábl. 3.3.3.1. fejezet). A Tc32 II kitermelése 74\%-os volt.

5.5.2. Konvergens szintézis kísérletek

A konvergens szintézis azt feltételezte, hogy a hat Cys közül egy cisztein párt a natív izomerből rendre szelektív védőcsoporttal láttam el, a többi négy szabad tiol csoportot az „oxidatív folding” módszerével kapcsoltam össze.

A TGKA32-C ${ }^{12,16,31,33}$-Acm és a TGKA-C ${ }^{7,16,26,33}$-Acm szintézise Boc-Ala-PAM hordozón történt $(0.5 \mathrm{mmol}$, borítottság: $0.7 \mathrm{mmol} / \mathrm{g})$ az általános szintézismódszerben leírt manuális Boc-SPPS protokoll szerint. A peptidlánc felépítéséhez használt aminosavak: Boc- $L-\mathrm{Ala}-\mathrm{OH}$ ，Boc- $L-\mathrm{Asp}(\mathrm{OcHx})-\mathrm{OH}$ ，Boc- $L-\mathrm{Cys}(\mathrm{Meb})-\mathrm{OH} ， B o c-L-$ Cys(Acm)-OH，Boc- $L-G l y-O H ， B o c-L-G l n-O H ， B o c-L-G l u(O c H x)-O H ， B o c-L-L e u-$ $\mathrm{OH} \cdot \mathrm{H}_{2} \mathrm{O}$, Boc- $L$-Lys(2ClZ)-OH, Boc- $L-\mathrm{Met}-\mathrm{OH}$, Boc- $L$-Ser(Bzl)-OH, Boc- $L$-Pro-OH, Boc- $L$-Thr(Bzl)-OH. A peptideket anizolt $(0.4 \mathrm{ml})$, dimetil-szulfidot $(1.6 \mathrm{ml}), p$-krezolt $(0.4 \mathrm{ml})$ és DTT-t $(200 \mathrm{mg})$ tartalmazó folyékony HF-dal $(20 \mathrm{ml})$ hasítottam le a hordozóról $-5^{\circ} \mathrm{C}$-on 45 perc alatt. A nyers lineáris peptidet éteres kicsapással nyertem ki a hasítóelegyböl. 
A hasítás után szabadon maradt tiolcsoportok összeoxidálására próbareakciókat végeztem a nyers peptidekkel:

a. a nyers peptidet $(2-2 \mathrm{mg})$ feloldottam ammónium-acetát $(2 \mathrm{ml}, \mathrm{pH} 7.5)$ pufferben és 24 órán át kevertettem. A reakciót analitikai RP-HPLC-n követtem.

b. a nyers peptidet (2-2 mg) ammónium-acetát puffer (pH 7.5): acetonitril (1:1) elegyében oldottam, hozzáadtam Clear-ox gyantát $(15 \mathrm{mg}$, borítottság: $0.21 \mathrm{mM} / \mathrm{g})$, majd 4 órán keresztül kevertettem. A reakciót analitikai RP-HPLC-n követtem, az eluálódó frakciókat tömegspektrometriával ellenőriztem. A reakcióelegyet szürtem, mostam a gyantát acetonitril:víz-zel és az oldatot liofilizáltam.

Az első diszulfidhíd kialakítása után, az Acm-védőcsoport eltávolítására és a keletkező szabad tiolcsoportok összekapcsolására végeztem próbareakciókat, ehhez a $b$. pontban kapott termékeket használtam:

c. a védett peptideket ecetsav:víz 4:1 (v/v) elegyében oldottam, hozzáadtam tízszeres fölöslegben $\mathrm{I}_{2}$-ot és 1 órán át kevertettem, majd vízzel a térfogat kétszeresére hígítottam az oldatokat, a feleslegben levő jódot átráztam kloroformba és a vizes fázisokat liofilizáltam.

d. a védett peptideket metanol:víz 8:2 (v/v) elegyében oldottam, hozzáadtam tízszeres fölöslegben $\mathrm{I}_{2}$-t és 30 percig kevertettem, majd lepároltam a MeOH-t és a feldolgozásnál az elöző pontban leírtak szerint jártam el.

A keletkező Tc32 izomerek izolálásához a nyers lineáris peptidek (TGKA$\mathrm{C}^{12,16,31,33}$-Acm és a TGKA-C $\left.\mathrm{C}^{7,16,26,33}-\mathrm{Acm}\right)(50-50 \mathrm{mmol})$ kis mennyiségét Tris-HCl puffer (pH 8.4):acetonitril (1:1) elegyében oldottam, hozzáadtam 6 ekv. Clear-ox ${ }^{\mathrm{TM}}$ gyantát (borítottság: $0.21 \mathrm{mmol} / \mathrm{g}$ ), amelyet előzőleg 30 percig DCM-ban $(30 \mathrm{ml})$ duzzasztottam és mostam DCM-nal, DMF-dal, MeOH-lal és acetonitril:víz (1:1) elegyével $(20-20 \mathrm{ml}) .4$ óra után szürtem az elegyeket, átmostam a gyantákat egy kis térfogat acetonitril:víz (1:1) eleggyel, vákuum alatt lepároltam az acetonitril nagy részét, vízzel kihígítottam és liofilizáltam a kapott oldatotokat. Az így kapott ciklizált peptideket szemipreparatív HPLC-n tisztítottam és a következő reakcióhoz az tisztított termékeket használtam. Az Acm-védőcsoport eltávolítása és a keletkező szabad tiol csoportok összeoxidálása egy lépésben történt: oldottam a védett peptideket metanol:víz 8:2 (v/v) elegyében, hozzáadtam tízszeres fölöslegben $\mathrm{I}_{2}$ - $\mathrm{t}$ és 30 percen át kevertettem. A reakció 
végén lepároltam vákuum alatt a metanolt, kihígítottam az oldatokat a térfogat kétszeresére vízzel, majd a jód feleslegét átráztam kloroformba, a vizes oldatokat meg liofilizáltam. A tisztítás során izoláltam a harmadik, illetve a negyedik Tc32 izomer: Tc32 III, illetve Tc32 IV. A Tc32 III ill. Tc32 IV peptidek kitermelése 52-58\%-os volt.

A TGKA-C $\mathbf{C}^{\mathbf{7 , 1 2 , 2 6 , 3 1}}$-Acm peptid szintézise Fmoc-Ala-Wang hordozón (0.25 mmol, borítottság: $0.75 \mathrm{mmol} / \mathrm{g}$ ) történt CEM mikrohullámú szintetizátor segítségével. A peptidlánc felépítéséhez használt aminosavak: Fmoc- $L-\mathrm{Ala}-\mathrm{OH}, \mathrm{Fmoc}-L-\mathrm{Asp}(\mathrm{O} t \mathrm{Bu})-\mathrm{OH}$, Fmoc- $L$-Cys(Acm)-OH, Fmoc- $L-\mathrm{Cys}(\mathrm{Trt})-\mathrm{OH}$, Fmoc- $L-\mathrm{Gly}-\mathrm{OH}$, Fmoc- $L-\mathrm{G} \ln (\mathrm{Trt})-\mathrm{OH}$, Fmoc- $L-\mathrm{Glu}(\mathrm{O} t \mathrm{Bu})-\mathrm{OH}$, Fmoc- $L$-Leu-OH, Fmoc- $L$-Lys(Boc)-OH， Fmoc- $L-M e t-\mathrm{OH}$, Fmoc- $L-\operatorname{Ser}(t \mathrm{Bu})-\mathrm{OH}, \quad$ Fmoc- $L$-Pro-OH, Fmoc- $L$ - $\mathrm{Th}(t \mathrm{Bu})-\mathrm{OH} . \quad \mathrm{Az}$ aminosavak kapcsolásához HBTU, HOBt elegyét használtam DIEA jelenlétében. A kapcsolószereket a védett aminosav-származékokkal együtt négyszeres fölöslegben használtam. A peptidet TFA/víz/DTT/TIS 83:10:5:2 (v/v/m/v\%) arányú elegyével $(10 \mathrm{ml})$ hasítottam le a hordozóról 3 óra alatt, lepároltam a TFA-t és jéghideg éterrel kicsaptam a terméket, szürtem, átmostam dietil-éterrel, majd leoldottam a peptidet ecetsav-víz elegyével (10 v/v\%) és liofilizáltam.

Az optimalizált CEM protokollt a 27. táblázat foglalja össze.

27. táblázat: Az optimalizált CEM protokoll

\begin{tabular}{|c|c|c|c|c|c|}
\hline CEM Protokoll & $\begin{array}{c}\text { Lépés } \\
\text { módja }\end{array}$ & $\begin{array}{c}\text { Lépések } \\
\text { száma }\end{array}$ & $\begin{array}{c}\text { Magnetron } \\
\text { teljesítmény }(\mathbf{W})\end{array}$ & $\begin{array}{c}\text { Max. } \\
\text { hőmérséklet }\left({ }^{\circ} \mathbf{C}\right)\end{array}$ & $\begin{array}{c}\text { Reakcióidö } \\
(\mathbf{s e c})\end{array}$ \\
\hline Fmoc-hasítás & ismételt & 1 & 35 & 75 & 30 \\
\hline Ált. kapcsolás & dupla & 1 & 40 & 75 & 180 \\
\hline Cys & dupla & 2 & 26 & 50 & 120 \\
kapcsolása & & 25 & 50 & 240 \\
\hline
\end{tabular}

Az ötödik Tc32 izomer (Tc32 V) izolálását a fentiekben leírt előkísérletek előzték meg. A tisztításhoz szintén a nyers lineáris Tc32-C $\mathrm{C}^{7,12,26,31}-\mathrm{Acm}$ peptidből $(50 \mathrm{mmol})$ indultam ki. Az előállított termékek analitikai jellemzését a 14. tábl. foglalja össze. A Tc32 V peptid kitermelése 55\%-os volt. 
5.5.3. A lépésenkénti regioszelektív cisztein párosítások módszere

A Tc32 natív izomerjének előállítására lépésenkénti regioszelektív cisztein párosítások módszerével a választott védőcsoportok: $\mathrm{S} t \mathrm{Bu}, \mathrm{Trt}, \mathrm{Acm}$.

A szintézis első lépéseként hozzákapcsoltam a $C$-terminális aminosavat a gyantához: Wang polimert (2 mmol, borítottság: $0.86 \mathrm{mmol} / \mathrm{g})$ DMF-ban $(10 \mathrm{ml})$ duzzasztottam, majd hozzáadtam a DMF-ban (10 ml) oldott 4-4 ekv. Fmoc- L-Ala-OH-t, DCC-t és HOBt-t, majd beleszórtam az elegybe 0.2 ekv. 4-dimetil-aminopiridint. Ismételt kapcsolást alkalmaztam: 4, majd 24 órán keresztül reagáltattam. A hordozó mosása után, Gisin-teszt segítségével megállapítottam a hordozó borítottságát: $0.49 \mathrm{mmol} / \mathrm{g}$. A következő kapcsolási reakcióknál az új borítottságot vettem alapul. A peptid további szintézise az általános szintézismódszerben leírt manuális Fmoc-SPPS protokoll szerint történt. A peptidlánc felépítéséhez használt további aminosavak: Fmoc- $L-A l a-O H$, Fmoc$L-\mathrm{Asp}(\mathrm{O} t \mathrm{Bu})-\mathrm{OH}$, Fmoc- $L$-Cys(Acm)-OH, Fmoc- $L-\mathrm{Cys}(\mathrm{S} t \mathrm{Bu})-\mathrm{OH}$, Fmoc- $L$-Cys(Trt)$\mathrm{OH}$, Fmoc- $L-\mathrm{Gly}-\mathrm{OH}$, Fmoc- $L-\mathrm{G} \ln (\mathrm{Trt})-\mathrm{OH}$, Fmoc- $L-\mathrm{Glu}(\mathrm{O} t \mathrm{Bu})-\mathrm{OH}$, Fmoc- $L-\mathrm{Leu}-\mathrm{OH}$, Fmoc- $L$-Lys(Boc)-OH, Fmoc- $L-\mathrm{Met}-\mathrm{OH}$, Fmoc- $L-\mathrm{Ser}(t \mathrm{Bu})-\mathrm{OH}$, Fmoc- $L$-Pro-OH, Fmoc$L-\operatorname{Thr}(t \mathrm{Bu})-\mathrm{OH} . \quad$ A TGKA-C $\mathrm{C}^{7,26}-\mathrm{Acm}, \mathrm{C}^{16,33}-\mathrm{St} \mathrm{Bu}$ peptid hordozóról való hasítása TFA $/ \mathrm{H}_{2} \mathrm{O} / \mathrm{DTT}$ 92:5:3 (v/v/m\%) elegyével $(10 \mathrm{ml})$ történt 3 óra alatt. A nyers lineáris peptidet éteres kicsapással nyertem ki a hasítóelegyből.

A regioszelektív diszulfid hidak kialakításához a reakciókat előzetesen optimalizáltam. Próbareakciókat végeztem a peptid kis részleteivel, ezeket analitikai RPHPLC-n követtem, az eluálódó frakciókat tömegspektrometriával ellenőriztem:

a. a lineáris TGKA-C $\mathrm{C}^{7,26}-\mathrm{Acm}, \mathrm{C}^{16,33}-\mathrm{StBu}$ peptidet $(5 \mathrm{mg})$ feloldottam vízben $(10 \mathrm{ml})$ és 24 órán át kevertettem levegőn.

b. a lineáris peptidet $(5 \mathrm{mg})$ ammónium-acetát pufferben $(10 \mathrm{ml}, \mathrm{pH} 7.5) 10$ percen keresztül kevertettem levegőn.

c. a lineáris peptidet $(5 \mathrm{mg}) \mathrm{Gly}-\mathrm{NaOH}$ pufferben $(10 \mathrm{ml}, \mathrm{pH} 9.7) 24$ órán át kevertettem levegön.

d. a lineáris peptidet (5 mg) ammónium-acetát pufferben ( $\mathrm{pH}$ 6.5):acetonitril (1:1) elegyében $(10 \mathrm{ml})$ oldottam, $12 \mathrm{ekv}$. Clear-ox ${ }^{\mathrm{TM}}$ gyantát (borítottság: $0.21 \mathrm{mmol} / \mathrm{g}$ ) adtam hozzá, majd 4 órán keresztül kevertettem. 
A lineáris TGKA-C $\mathrm{C}^{7,26}-\mathrm{Acm}, \mathrm{C}^{16,33}-\mathrm{S} t \mathrm{Bu}$ peptid $(40 \mathrm{mmol})$ kis részletét a $d$. pontban leírtak szerint oxidáltam. A további kísérletekhez a ciklizált terméket használtam:

e. a peptidet $(5 \mathrm{mg})$ ammónium-acetát pufferben $(10 \mathrm{ml}, \mathrm{pH} 7.5)$ oldottam, hozzáadtam 10x-es fölöslegben Cys-t és 10 percen át kevertettem.

f. a peptidet $(5 \mathrm{mg})$ ammónium-acetát pufferben $(10 \mathrm{ml}, \mathrm{pH} 7.5)$ oldottam, hozzáadtam 5x-ös fölöslegben Cys-t és 10 percen keresztül kevertettem.

A továbbiakban a nyers - egy diszulfid hidat már tartalmazó - védett TGKA$\mathrm{C}^{7,26}-\mathrm{Acm}, \mathrm{C}^{16,33}-\mathrm{S} t \mathrm{Bu}$ peptidet az $f$. pontban leírtak szerint oxidáltam és szemipreparatív RP-HPLC-n tisztítottam. Így a két diszulfid hidat tartalmazó Tc32-C $\mathrm{C}^{7,26}$-Acm peptidet reagáltattam a továbbiakban:

g. a peptidet $(2 \mathrm{mg})$ metanol:víz 8:2 (v/v) elegyében $(2 \mathrm{ml})$ oldottam, hozzáadtam $6 \mathrm{x}$-os fölöslegben $\mathrm{I}_{2}$-t és 30 percen át kevertettem. Feldolgozáshoz lepároltam a MeOH-t, vízzel a térfogat kétszeresére hígítottam az oldatot, a feleslegben levő jódot átráztam kloroformba és a vizes fázist liofilizáltam.

h. a peptidet $(2 \mathrm{mg})$ metanol:víz 8:2 (v/v) elegyében $(2 \mathrm{ml})$ oldottam, hozzáadtam $6 \mathrm{x}$-os fölöslegben $\mathrm{I}_{2}$-t és 1.5 órán keresztül kevertettem. A rekció feldolgozásához lepároltam a $\mathrm{MeOH}-\mathrm{t}$, a maradék oldatot vízzel a térfogat kétszeresére hígítottam, a feleslegben levő jódot átráztam kloroformba és a vizes fázist liofilizáltam.

A három diszulfid hidat tartalmazó termék izolálásához a tisztított TGKA-C ${ }^{7,26}$ Acm peptid nagyobb mennyiségét használtam. A $h$. pontban leírtak szerint egy lépésben távolítottam el az Acm védőcsoportot és oxidáltam a keletkező szabad tiol csoportokat. A keletkező nyers terméket szemipreparatív HPLC-n tisztítottam és izoláltam a föterméket, (amely azonos a Tc32 I izomerrel) és egy hatodik Tc32 izomert: Tc32 VI - az izomerek analitikai jellemzőit a 14. tábl. foglalja össze. A Tc32 I ill. Tc32 VI peptidek kitermelése $43-49 \%$-os volt.

\subsection{A C3a9 szimmetrikus dimer előállítása}

A C3a9 dimer (DCCNYITR) 2 szintéziséhez regioszelektív diszulfid híd kiépítési stratégiát alkalmaztam: a dimer két szelektíven S-védett A és B láncát lépésenként zártam össze egy tiolízis és egy jodolízis során . 


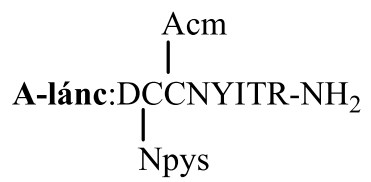

B-lánc: $\left.\right|_{\mathrm{DCCN}} ^{\mathrm{SH}}$

50. ábra: A szintetizált A- és B-lánc szerkezete

$A$ védett $A-$, illetve $B$-lánc (50. ábra) manuális Boc kémiával készült MBHA hordozón (0.2 mmol, borítottság: $1.06 \mathrm{mmol} / \mathrm{g})$. A kapcsolások során 3-3 ekv. DCC-t és Boc-védett aminosavat használtam. A kapcsolási idő általában 2 óra volt. A felhasznált aminosavak oldallánc védőcsoportjai HF-érzékeny csoportok voltak (D-OcHx, C-Meb, Y-2BrZ, T-Bzl, R-Tos), kivéve az A-lánc $C^{2}$-Npys, illetve $C^{3}$-Acm, illetve a B-lánc $C^{3}$ Acm aminosavát. A kész peptideket anizolt $(0.4 \mathrm{ml})$, dimetil-szulfidot $(1.6 \mathrm{ml}), p$-krezolt $(0.4 \mathrm{ml})$ tartalmazó folyékony HF-dal $(20 \mathrm{ml})$ hasítottam le a szilárd hordozóról $-5^{\circ} \mathrm{C}$-on 60 perc alatt. A nyers peptidek azonosítása RP-HPLC-vel és ESI-MS-el történt.

Feloldottam B-láncú $\left[\mathrm{C}^{2}(\mathrm{~S}\right.$-tiol $\left.), \mathrm{C}^{3}(\mathrm{Acm})\right]$ peptidet $(16.5 \mu \mathrm{mol}) \mathrm{NH}_{4} \mathrm{OAc}$ pufferben (17 ml, pH 8.5) és lassan az A-láncú peptid $(16.5 \mu$ mol $) \mathrm{NH}_{4} \mathrm{OAc}$ puffer $(20$ ml, pH 8.5) oldatához adtam. A reakciót szobahőmérsékleten hagytam keveredni és időnként mintát vettem analízisre. 1 óra után liofilizáltam az elegyet. A nyers termék: $\left[\mathrm{C}^{3}\right.$ $\left.\mathrm{A}(\mathrm{Acm}) / \mathrm{C}^{3} \mathrm{~B}(\mathrm{Acm})\right](\sim 16.5 \mu \mathrm{mol})$. A liofilizált terméket ecetsavban oldottam $(70 \mathrm{ml}$, $50 \mathrm{v} / \mathrm{v} \%)$ és $10 \mathrm{ekv} \mathrm{I}$-t csepegtettem hozzá ecetsavban $(5 \mathrm{ml}, 80 \mathrm{v} / \mathrm{v} \%)$ oldva. 2 óra után feldolgoztam a reakciót: vízzel a térfogat kétszeresére hígítottam az oldatot, a feleslegben levő jódot átráztam DCM-ba és a vizes fázist liofilizáltam. A keletkező dimer peptidet szemipreparatív HPLC-n tisztítottam és izoláltam. A kész termék analitikai jellemzőit a 17. táblázat foglalja össze. A C3a9 szimmetrikus dimer kitermelése 83\%-os volt.

\subsection{Gab1 adapter fehérje eredetü foszfopeptidek előállítása}

A Gab1 eredetű foszfopeptidek (ld. 18. táblázat) szintézise TentaGel R RAM hordozón történt $(0.2 \mathrm{mmol}$, borítottság: $0.18 \mathrm{mmol} / \mathrm{g})$. A peptidláncok felépítéséhez használt aminosavak: Fmoc-Asp $(\mathrm{O} t \mathrm{Bu})-\mathrm{OH}$, Fmoc-Glu( $\mathrm{O} t \mathrm{Bu})-\mathrm{OH}$, Fmoc-Gln(Trt)-OH, Fmoc-Gly-OH, Fmoc-Leu-OH, Fmoc-Lys(Boc)-OH, Fmoc-Tyr-OH, Fmoc-Val-OH. Az aminosavakat az aktiváló reagensekkel együtt (HOBt, DCC) háromszoros fölöslegben kapcsoltam 3 órán át. A polimer mosása, a kapcsolási reakció ellenőrzése, a Fmoc-hasítás menete az általános szintézismódszerben leírt módon történt. Az oldallánc-védőcsoporttal 
nem rendelkezö tirozin foszfatálására közvetlenül a Fmoc-Tyr-OH beépítése után került sor: a reakció előtt frissen desztillált THF-nal $(10 \mathrm{ml})$ mostam a hordozót, majd THF-ba (8 ml) szuszpendáltam, hozzáöntöttem az előzőekben elkészített 15-20 ekv. di-terc-butil$N, N$-dietil-foszforamiditet, szórtam a rekcióelegybe 15-20 ekv. 1H-tetrazolt és 2 órán keresztül kevertettem szobahőmérsékleten; reakció lejátszódása után a hordozót többször mostam frissen deszt. THF-nal (10-10 ml), majd 14 (v/v\%)-os tercbutil-hidroperoxiddal $(10 \mathrm{ml})$ oxidáltam. A reakciót 2 órán át kevertettem $0^{\circ} \mathrm{C}$-on, majd többször mostam a szilárd hordozót THF-nal és DCM-nal (10-10 ml). A peptidlánc továbbépítése a Fmoccsoport hasításával folytatódott.

A peptideket későbbi biotinnal való jelöléséhez - kivéve azokat a szekvenciákat melyek Lys-t is tartalmaznak, 2.5 óra alatt hasítottam le a hordozóról 92:5:3 TFA/víz/DTT (v/v/m\%) elegyével $(10 \mathrm{ml})$. A TFA-t lepároltam a hordozóról, jéghideg éterrel kicsaptam a terméket, szürtem, dietil-éterrel mostam a hordozót, majd a szürőről a peptidet acetonitril-víz elegyével leoldottam és az oldatot liofilizáltam. A biotinilálás előtt, a nyers peptid minőségétől függően, a peptidek kis részletét szemipreparatív RPHPLC-n megtisztítottam. Gab1 eredetű foszfopeptidek kitermelése 72-85\%-os volt.

5.7.1. Módosított GDLDpe peptidek előállítása

Az általam szintetizált módosított GDLDpe peptideket a 19. táblázat mutatja be. A GDLD és GDFLD peptidek szintézise TentaGel R RAM polimeren $(0.2 \mathrm{mmol}$, borítottság: $0.18 \mathrm{mmol} / \mathrm{g}$ ) történt az általános szintézismódszerben leírt Fmoc-kémiával. A szintézis során TFA-ra érzékeny oldallánc védőcsoportokat használtam. A peptideket 95:5 (v/v\%) TFA/víz elegyével (10 ml) hasítottam le a szilárd hordozóról, gyökfogóként DTT-t $(3 \mathrm{~m} / \mathrm{v} \%)$ alkalmaztam. A nyers peptideket éteres kicsapással nyertem ki a reakcióelegyből. A módosított nyers GDLDpe peptidek kitermelése 76\%-os volt.

5.7.2. A Gab1 eredetü foszfopeptidek és módosított származékainak jelölése biotinnal

A biotinilálást szilárd fázison végeztem a GDLD, GDFLD, DKYLpe, KQLDpe, illetve a DKLDpe foszfopeptidek esetében. A peptid-polimer $N$-terminálisáról lehasítottam a Fmoc-védőcsoportot és 3 ekv. biotinil- $\varepsilon$-amino kapronsavat adtam hozzá 3-3 ekv. DCC és HOBt eleggyel végeztem a kapcsolást DMF oldatban. A kapcsolási 
reakciót ninhidrin-próbával ellenőriztem. A jelölt peptidet a hordozóról a szokásos módon hasítottam és a nyers termékeket szemipreparatív HPLC-n tisztítottam.

A QVDLpe, EYDLpe, VELDpe, QVLDpe peptidek biotinilálása oldat fázisban történt. A biotiniláláshoz a nyers peptidek $(\sim 15-20 \mu \mathrm{mol})$ kis részletét használtam. A peptideket oldottam DMF-ban $(1 \mathrm{ml})$, hozzáadtam vizet $(100 \mu \mathrm{l})$, az oldat pH-ját 8-9-re állítottam DIEA-val, majd hozzáadtam 1.5-2 ekv. biotinil-e-amino-kapronsav $N$ hidroxiszukcinimid aktív észtert. A reakciót analitikai RP-HPLC-n követtem, a terméket ESI-MS-val ellenőriztem. A reakcióidő 2-4 óra alatt ment végbe, ezután a reakcióelegyet szemipreparatív RP-HPLC-re injektáltam és tisztítottam. A előállított termékek analitikai jellemzőit a 20. tábl. foglalja össze.

A biotinilált peptidek 72-77\%-os kitermeléssel állíthatók elő.

5.7.3. A sejtmembrán permeábilis Okt-R8C előállítása

A sejtmembrán permeábilis peptid szintézise manuális szilárd fazisú Bockémiával történt MBHA polimeren ( $1 \mathrm{mmol}$, borítottság: $1.03 \mathrm{mmol} / \mathrm{g})$. A szintézis során felhasznált aminosavak: $\operatorname{Arg}(\operatorname{Tos})$, Cys(Meb). A kapcsolásokhoz 3-3 ekv. Boc-aminosav származékot, DCC-t és HOBt-t alkalmaztam. Az $N$-terminális Arg Boc-védőcsoportjának eltávolítása után 4 ekv. mennyiségben az oktánsavat kapcsoltam, 4-4 ekv. DCC-HOBt jelenlétében. A kész peptidet folyékony HF-dal (20ml) hasítottam le a hordozóról, gyökfogóként anizolt $(0.4 \mathrm{ml})$, dimetil-szulfidot $(1.6 \mathrm{ml})$ és $p$-krezolt $(0.4 \mathrm{ml})$ alkalmaztam. A nyers terméket szemipreparatív RP-HPLC-n tisztítottam és analitikailag jellemeztem (ld. 22. tábl.). Az Okt-R8C peptid előállítását 46\%-os kitermeléssel valósítottam meg.

5.7.4. Gab1 eredetű sejtmembrán permeábilis foszfopeptid-konjugátumok előállítása

A kísérletekben felhasznált szintetikus, Gab1 eredetü peptid-szekvenciákat a 21. táblázat foglalja össze.

A peptidek egy hosszabb szénláncot tartalmazó távolságtartón keresztül kapcsoltam az Okt-R8C-hez. A megfelelő hordozóra kötött peptidek szabad N-terminális $\alpha$ aminocsoportjához kapcsoltam 3 ekv. mennyiségben $\varepsilon$-maleimido-kapronsavat 3-3 ekv. DCC és HOBt segítségével. A reakciót ninhidrin-teszttel ellenőriztem. A peptidek lehasítása a szilárd hordozóról a szokásos módon történt. A következőkben a nyers 
peptidek 10-15 $\mu$ mol-os részletét használtam. Feloldottam az $\varepsilon$-maleimidokapronsavamid-peptidet foszfát pufferben $(1.5 \mathrm{ml}, \mathrm{pH}$ 6.5), annyi guanidin-hidroklorid sót adtam hozzá, hogy $8 \mathrm{~mol} / \mathrm{dm}^{3}$-es oldatot kapjak, majd 1.5 ekv. Okt-R8C peptiddel reagáltattam. A reakciót analitikai HPLC-n követtem és a terméket ESI-MS-val ellenőriztem. A reakcióidő általában 1-2 óra volt, ezután a reakcióelegyet szemipreparatív HPLC-re injektáltam és tisztítottam. A tiszta termékek analitikai paramétereit a 23. táblázat foglalja össze. A sejtpermeábilis foszfopeptid-konjugátumok előállítása 88\%-os termeléssel valósult meg.

\section{8. $\quad \beta$-Modellpeptidek és minifehérjék előállítása}

5.8.1. Betanova-peptidek előállítása

A Betanova peptidek (RGWSVQNGKYTNNGKTTEGR) előállítása szilárd fázisú technika segítségével történt Boc-kémiával. A szilárd hordozó Merrifield polimer ( $0.5 \mathrm{mmol}, 1.1 \mathrm{mmol} / \mathrm{g})$ volt a Betanova-OH esetén, a Betanova- $\mathbf{N H}_{2}$ esetében MBHA hordozót használtam $(0.5 \mathrm{mmol}$, borítottság: $1.03 \mathrm{mmol} / \mathrm{g})$. A felhasznált aminosavak védőcsoportjai a következők voltak: $\operatorname{Arg}(\mathrm{Tos}), \mathrm{Glu}(\mathrm{OcHx}), \quad \operatorname{Lys}(2 \mathrm{CIZ}), \operatorname{Ser}(\mathrm{Bzl})$, $\operatorname{Thr}(\mathrm{Bzl})$ és Tyr(2BrZ). A két szintézis az első aminosav kapcsolási módjában tér el. Az MBHA hordozóhoz a peptidkémiában használatos kapcsolószerekkel kapcsoltam az első aminosavat, Merrifield polimerhez a $C$-terminális Boc-Arg(Tos) kapcsolásához kétszeres fölöslegben alkalmaztam a védett aminosavszármazékot és négyszeres fölöslegben a KFot $70^{\circ} \mathrm{C}$-on 48 órán át. Minden további aminosav kapcsolása a standard $\mathrm{DCC}$ vagy DCC/HOBt protokoll szerint történt, háromszoros fölöslegben használva a reagenseket. A peptidek folyékony HF-dal $(20 \mathrm{ml})$ hasítottam le a szilárd hordozókról $\left(-5^{\circ} \mathrm{C}, 60\right.$ perc), anizol $(0.4 \mathrm{ml})$, dimetil-szulfid $(1.6 \mathrm{ml})$ és $p$-krezol $(0.4 \mathrm{ml})$ gyökfogók jelenlétében. Hasítás után, a hordozóra kicsapott peptideket éterrel kicsaptam és vízzel oldottam le. A nyers peptidek tisztítása szemipreparatív RP-HPLC-én történt, analitikai jellemzésüket a 24. táblázat foglalja össze. A Betanova peptidek kitermelése $85-88 \%$-os volt.

5.8.2. SETE-peptidek előállítása

A SETE-S3(p) (SES(p)YINPDGTWTKTE-OH) peptidet szilárd fázisú technika segítségével állítottam elő Fmoc-kémiával Wang polimeren $(0.25 \mathrm{mmol}$, borítottság: 0.86 mmol/g). A felhasznált aminosavak védőcsoportjai a következők voltak: Asn(Trt), 
$\operatorname{Asp}\left(\mathrm{OBu}^{t}\right), \mathrm{Glu}\left(\mathrm{OBu}^{t}\right)$, Lys(Boc), $\operatorname{Ser}\left(\mathrm{Bu}^{t}\right), \operatorname{Thr}\left(\mathrm{Bu}^{t}\right)$ és $\operatorname{Tyr}\left(\mathrm{Bu}^{t}\right)$. A C-terminális Fmoc$\mathrm{Glu}\left(\mathrm{OBu}^{\mathrm{t}}\right)$-t a hordozóhoz négyszeres fölöslegben használt aminosav és DCC/HOBt-vel kapcsoltam, 1 ekv. 4-dimetil-amino-piridin hozzáadásával. Minden további aminosav kapcsolása a standard DCC vagy DCC/HOBt protokoll szerint történt háromszoros fölöslegben használva a reagenseket. $\mathrm{A} \mathrm{Ser}^{13}$ oldalláncába a foszfát-észter beépítéséhez: első lépésben a védőcsoport nélküli szerint foszfonáltam $20 \mathrm{ekv}$. tercbutil- $H$-foszfonáttal 40 ekv. pivaloil-klorid jelenlétében 1:1 (v/v) piridin/DMF-et használva oldószerként; ezt követte az oxidáció $\mathrm{I}_{2}$ tartalmú $(1 \mathrm{~m} / \mathrm{v} \%)$ piridin/víz 98:2 (v/v) eleggyel. A peptidet 95:5 (v/v) TFA/víz elegyével $(10 \mathrm{ml}) 2.5$ óra alatt hasítottam le a szilárd hordozóról szobahőmérsékleten, gyökfogóként DTT-t ( $3 \mathrm{~m} / \mathrm{v} \%)$ alkalmaztam. A hordozó szürése után, a peptidet jéghideg éterrel csaptam ki az oldatból. A kicsapott peptidet, szürtem, majd szárítottam. A nyers peptid tisztítását szemipreparatív RP-HPLC-én végeztem. A peptid kitermelése 74\%-os volt.

A SETE (SESYINPDGTWTKTE-OH), SETE-S3E (SEEYINPDGTWTKTEOH), ERVSK (ERVYINPDGTWTVSK-OH), ERISK (ERIYINPDGTWTVSK-OH), ESVSK (ESVYINPDGTWTVSK-OH), ESISK (ESIYINPDGTWTVSK-OH) peptidek szintézise manuális Boc-kémiával történt Merrifield polimeren $(0.5 \mathrm{mmol}, 1.1 \mathrm{mmol} / \mathrm{g})$. A felhasznált aminosavak védőcsoportjai a következők voltak: $\operatorname{Arg}(\operatorname{Tos}), \operatorname{Asp}(\mathrm{OcHx})$, Glu(OcHx), Lys(2CIZ), Ser(Bzl), Thr(Bzl), és Tyr(2BrZ). A C-terminális Boc$\mathrm{Glu}(\mathrm{OcHx})$-t kétszeres fölöslegben használt aminosav és négyszeres fölöslegben használt KF-dal kapcsoltam a szilárd hordozóhoz $70^{\circ} \mathrm{C}$-on 48 órán át. Minden további aminosav kapcsolása a standard DCC vagy DCC/HOBt protokoll szerint történt, háromszoros fölöslegben használva a reagenseket. A peptideket folyékony HF-dal hasítottam le a hordozóról $\left(-5^{\circ} \mathrm{C}, 60\right.$ perc), anizol, dimetil-szulfid és $p$-krezol hozzáadásával. Hasítás után, a peptid éteres kicsapással nyertem ki, ecetsavval és vízzel oldottam le. A nyers peptid tisztítása szemipreparatív RP-HPLC-én történt. A SETE peptidek kitermelése 68$88 \%$-os volt.

A SETE-peptidek analitikai paramétereit a 24. tábl. foglalja össze.

5.8.3. Tc5b foszfo- és glikoanalógok előállítása

A Tc5b-S13(p) (NLYIQWLKDGGPS(p)SGRPPPS-OH) peptid szintézisét manuális szilárd fázisú szintézissel Fmoc-Ser $(t \mathrm{Bu})$-Wang polimeren $(0.2 \mathrm{mmol}$, 
borítottság: $0.83 \mathrm{mmol} / \mathrm{g}$ ) végeztem Fmoc-kémiával. A felhasznált aminosavak védőcsoportjai a következők voltak: $\operatorname{Arg}(\mathrm{Pbf}), \operatorname{Asn}(\operatorname{Trt}), \operatorname{Asp}(\mathrm{O} t \mathrm{Bu}), \mathrm{Gln}(\operatorname{Trt}), \operatorname{Lys}(\mathrm{Boc})$, $\operatorname{Ser}(t \mathrm{Bu})$ és $\operatorname{Tyr}(t \mathrm{Bu})$. A kapcsoláshoz 3-3 ekv. Fmoc-aminosav származékot, DCC-t és HOBt-t használtam. A 13-as pozícióban levő szerinig a szintézist Fmoc-kémiával építettem fel. A Ser ${ }^{13}$-t oldallánc védőcsoport nélkül építettem be, előduzzasztottam a hordozót piridin/DMF 1:1 (v/v) elegyében $(20 \mathrm{ml})$, majd hozzáadtam 20 ekv. ammónium terc-butil $H$-foszfonátot 40 ekv. pivaloil klorid jelenlétében, a reakció oldószere piridin/DMF 1:1 (v/v) volt, a reakcióidő 4 óra szobahőmérsékleten. Ezután a hordozót piridinnel és DMF-dal (20-20 ml) mostam, majd jód tartalmú piridin/víz 98:2 (v/v) eleggyel $(20 \mathrm{ml}, 1 \mathrm{~m} / \mathrm{v} \%)$ oxidáltam 2 órán át szobahőmérsékleten. A szintézis után a szilárd hordozót piridinnel, DMF-dal, MeOH-lal és DCM-nal (15-15 ml) mostam. A Fmoc-hasítás után tovább építettem a peptidláncot a szokásos módon. A kész peptidet TFA/víz/DTT 92:5:3 (v/v/m\%) elegyével $(10 \mathrm{ml})$ hasítottam le a hordozóról 2.5 óra alatt. A nyers peptidet éteres kicsapással nyertem ki a hasítóelegyből és szemipreparatív HPLC-n tisztítottam, analitikailag jellemeztem (ld. 24. táblázat). A Tc5b-S13(p) előállítása 69\%-os kitermeléssel valósult meg.

Tc5b-monoszacharid (Leu-Lys-GlcNAc( $\beta 1-\mathrm{N})$ Asn-Gly-Gly-Pro-OH) glikopeptid Boc-Pro-Merrifield polimeren $(0.2 \mathrm{mmol}$, borítottság: $0.64 \mathrm{mmol} / \mathrm{g})$ készült Bocstratégiával. A beépített aminosavak közül a Lys-t Boc-L-Lys(Z)-OH formájában építettem be. A glikozilált aszparaginsav származék kapcsolása a többi aminosav származékhoz hasonlóan 3-3 ekv. DCC-t és HOBt-vel történt. A peptidet $\operatorname{HBr}$ [33 (v/v\%) -os oldat jégecetben] TFA oldatával $(10 \mathrm{v} / \mathrm{v} \%)$ hasítottam le a hordozóról, gyökfogóként DTT-t ( $2 \mathrm{~m} / \mathrm{v} \%)$ alkalmazva, a hasítási idő 2 óra volt szobahőmérsékleten. A nyers peptidet éteres kicsapással nyertem ki a reakcióelegyből, szemipreparatív HPLC-n tisztítottam és analitikailag jellemeztem (ld. 24. táblázat). A Tc5b-monoszacharid glikopeptid kitermelése $46 \%$-os volt.

Tc5b-diszacharid (Leu-Lys-GlcNAc( $\beta 1-4)$ GlcNAc( $\beta 1-\mathrm{N})$ Asn-Gly-Gly-Pro-OH) glikopeptid Boc-Pro-Merrifield polimeren $(0.1 \mathrm{mmol}$, borítottság: $0.64 \mathrm{mmol} / \mathrm{g})$ készült Boc-stratégiával. A szintézis során Boc- $L$-Lys(Z)-OH-t alkalmaztam. A glikozilált aszparaginsav származék a többi aminosav származékhoz hasonlóan lett beépítve 3-3 ekv. DCC-t és HOBt segítségével. A peptidet HBr [33 (v/v\%)-os oldat jégecetben] TFA 
oldatával $(10 \mathrm{v} / \mathrm{v} \%)$ hasítottam le a hordozóról, gyökfogóként DTT-t $(2 \mathrm{~m} / \mathrm{v} \%)$ alkalmaztam, a hasítási idő 2 óra volt szobahőmérsékleten. A nyers peptidet éteres kicsapással nyertem ki a reakcióelegyből, szemipreparatív HPLC-n tisztítottam és analitikailag jellemeztem. A Tc5b-diszacharid glikopeptid kitermelése 22\%-os volt.

5.8.3.1. Az $N$-[(9-hidroximetil)-2-fluorenil]borostyánkősav linker előállítása

A linker szintézisének egyszerüsített sémáját lásd 49. ábrán.

A szintézis első lépése a 2-(t-butiloxikarbonil-amino)fluorén előállítása. Ehhez a 2-amino-fluorént $(55 \mathrm{mmol})$ feloldottam dioxán:víz-ben 2:1 (v/v), hozzáadtam 2 $\mathrm{mol} / \mathrm{dm}^{3}$-es $\mathrm{NaOH}$ oldatot és jégfürdőben kevertem, majd hozzáadtam $1.1 \mathrm{ekv}$. di-t-butilpirokarbonátot és $25^{\circ} \mathrm{C}$-on kevertem további 24 órán keresztül. A reakció után az oldatot $1 \mathrm{~mol} / \mathrm{dm}^{3}$-es $\mathrm{KHSO}_{4}$-tal savanyítottam $\mathrm{pH} 3$-ig, szürtem és a szilárd fázist mostam vízzel, dioxán:víz-zel 1:1 (v/v), hexánnal, majd szárítottam $\mathrm{P}_{2} \mathrm{O}_{5}$-on.

A második lépés a 9-hidroximetil-2-amino-fluorén előállítása. Az előző lépés termékét, a 2-Boc-amino-fluorént THF-ban oldottam és óvatosan hozzáadtam 4 ekv. NaH-hez, továbbá 3 ekv. etil-formiátot adtam az elegyhez, szintén nagyon óvatosan. A reakcióidő 20 perc volt, ezután az elegyet jéggel hütöttem, hígítottam vízzel, lepároltam a THF-t, majd éterrel extraháltam a kívánt terméket. Az éteres fázist jégecettel savanyítottam $\mathrm{pH} 3$-ig, etil-acetáttal $3 \mathrm{x}$ extraháltam, mostam telített $\mathrm{Na}_{2} \mathrm{CO}_{3}$-tal, telített sóoldattal, szárítottam $\mathrm{Na}_{2} \mathrm{SO}_{4}$-on, majd szürtem a szárítószert, bepároltam a szerves fázist és a terméket $\mathrm{P}_{2} \mathrm{O}_{5}$-on szárítottam.

A szintézis harmadik lépése a redukció. Ehhez feloldottam HPLC-minőségü metanolban az előző lépés termékét és lassan hozzáadtam 1.1 ekv. $\mathrm{NaBH}_{4}$-t, amit előzőleg beoldottam kevés térfogat metanolban. A reakcióidő 3 óra volt. Feldolgozáshoz hígítottam az elegyet vízzel, pH 3-ig savanyítottam ecetsavval, majd a kivált anyagot átráztam etil-acetátba, szárítottam $\mathrm{Na}_{2} \mathrm{SO}_{4}$-on, szürtem a szárítószert, bepároltam és exikátorban szárítottam a terméket.

A következő lépésben lehasítottam a Boc védőcsoportot $4.5 \mathrm{~mol} / \mathrm{dm}^{3}$-es $\mathrm{HCl}$ dioxánnal: jégfürdőn kevertettem 2 órán át, majd további 1 órán keresztül szobahőmérsékleten. Feldolgozáshoz az oldatot bepároltam, aztán hígítottam DCM-nal $0^{\circ} \mathrm{C}$-on és a keletkező csapadékot szürtem, mostam DCM-nal, majd leoldottam vízzel, beállítottam a pH-t 8-ra és a kivált csapadékot extraháltam 3x etil-acetáttal. A szerves 
fázist sóoldattal extraháltam, szárítottam $\mathrm{Na}_{2} \mathrm{SO}_{4}$-on, szürtem a szárítószert, bepároltam az elegyet és a terméket exikátorban szárítottam.

Az ötödik lépés a szabad aminocsoport acilezése szukcinsavanhidriddel. Ehhez feloldottam az előző reakció termékét frissen desztillált THF-ba, majd lassan hozzáadtam a szukcinsavanhidridet 1.1 ekv. mennyiségben, amit előzőleg beoldottam kis térfogat THF-ba. A reakcióidő 2 óra, ezután a reakcióelegyet bepároltam. A kész linkert tömegspektrometriásan és analitikai RP-HPLC-n jellemeztem. A linker kitermelése 45\%os volt.

5.8.3.2. A Tc5b-diszacharid előállítása az N-[(9-hidroximetil)-2-fluorenil]borostyánkősav linker felhasználásával

A MBHA hordozóhoz (borítottság: $1.06 \mathrm{mmol} / \mathrm{g}$ ) 3 ekv. mennyiségben kapcsoltam a $N$-[(9-hidroximetil)-2-fluorenil]borostyánkősav linkert 3 ekv. DCC segítségével. A reakciót 24 órán át kevertettem, majd a szabadon maradt amino csoportokat acetileztem ecetsavanhidriddel. Az első aminosav kapcsolásához ismételt reakciót használtam, 4-4 ekv. aminosavszármazékot, DCC-HOBt-t alkalmaztam 2 ekv. 4dimetil-amino-piridin jelenlétében. A hordozó új borítottságát Gisin-teszttel ellenőriztem: $0.37 \mathrm{mmol} / \mathrm{g}$. A többi aminosav kapcsolása a már leírt módon történt. A kész glikopeptid hasítása a gyantáról piperidin/DCM oldattal $(40 \mathrm{v} / \mathrm{v} \%)$ történt, 1.5 óra alatt. A nyers terméket szemipreparatív HPLC-n tisztítottam és analitikailag jellemeztem (ld. 24. tábl.). A Tc5b-diszacharid glikopeptid kitermelése ezzel a módszerrel 44\% volt. 


\section{Irodalomjegyzék}

1. Jones J.H. J.Pept. Sci. 1999, 5, 465.

2. Du Vigneaud V., Ressler C., Swan C.M., Roberts C.W., Katsoyannis P.G. J. Am. Soc. 1954, 76, 3115.

3. Merrifield R.B. J. Am. Soc. 1963, 85, 2149.

4. $\quad$ Kappe C.O., Dallinger D. Mol Divers. 2009, 13,71.

5. Sabatino G., Papini A.M. Curr. Opinion Drug Discov. Dev. 2008, 11, 762.

6. $\quad$ Palasek S.A., Cox Z.J., Collins J.M. J. Peptide Sci. 2007, 13, 143.

7. Carpino L.A., Han G.Y.J. Org. Chem. 1972, 37, 3404.

8. Atherton E., Clive D.L.J., Sheppard R.C. J. Am. Soc. 1975, 97, 6584.

9. König W., Geiger R. Chem. Ber. 1970, 103, 788.

10. Barany G., Kneib-Cordonier N., Mullen D.G. Int. Pept. Prot. Res. 1987, 30, 705.

11. Fields G.B., Tian Z., Barany G. in Ed.: Grant, G.A. Freeman and Co., New York $1992,77$.

12. Kisfaludy L., Schőn I. Synthesis 1983, 325.

13. Carpino L.A. J. Am. Chem. Soc. 1993, 115, 4397.

14. Carpino L.A., El-Faham A., Minor C.A., Albericio F. J. Chem. Soc. Chem. Commun. 1994, 201.

15. Subiros-Funosas R., Prohens R., Barbas R., El-Faham A., Albericio F. Chem. Eur. J. 2009, 15(37), 9394.

16. El-Faham A., Subiros-Funosas R., Prohens R., Albericio F. Chem. Eur. J. 2009, $15,37,9405$.

17. Walsh C.T., Garneau-Tsodikova S., Gatto G.J. Angew. Chem. Int. Ed. 2005, 44, 7342.

18. Gilbert J. Adv. Enzymol. Relat. Areas Mol. Biol. 1990, 63, 69.

19. Annis I., Hargittai B., Barany G. in Methods Enzymol., 1997, 198.

20. Moroder L., Musiol H.-J., Götz M., Renner C. Biopolymers 2005, 85.

21. Boulege C., Musiol H-J., Prasad V., Moroder L. Chemistry Today 2006, 24(4), 24.

22. Isidro-Llobet A., Alvarez M., Albericio F. Chem. Rev. 2009, 109, 2455. 
23. Kellenberg C., Hietter H., Luu B. Peptide Res. 1995, 8(6), 321.

24. Cuthbertson A., Indrevoll B. Tetr. Lett., 2000, 41, 3661.

25. Akaji K., Fujino K., Tatsumi T., Kiso Y. J. Am. Chem. Soc. 1993, 115, 11384.

26. Barthgate R.A.D., Lin F., Hanson N.F., Otvos L., Guidolin A., Giannakis C., Bastiras S., Layfield S.L., Ferraro T., Ma S., Zhao C., Gundlach A.L., Samuel C., Tregear G.W., Wade J.D., Biochemistry 2006, 45, 1043.

27. Hossain M.A., Lin F., Zhang S., Ferraro T., Bathgate R.A., Tregear G.W., Wade J.D. Int. J. Pep. Prot. Res. 2006, 12(3), 211.

28. Chang J.Y., Li L. Biochemistry 2002, 41, 8405.

29. Chatrenet B., Chang J.Y. J. Biol. Chem. 1993, $268(28), 20988$.

30. Chang J.Y., Biochem J. 1994, 300, 643.

31. Tang J.G., Wang Z.H., Tregear G.W., Wade J.D. Biochemistry 2003, 2731.

32. Tam J.P., Wu C.R., Liu W., Zhang J.W. J. Am. Chem. Soc. 1991, 113, 6657.

33. Kamber B., Hartmann A., Eisler K., Riniker B., Rink H., Sieber P., Rittel W. in Helvetica chimica acta 1980, 63, 899.

34. Ennis E., Handy S.T. Molecules 2009, 14, 2235.

35. Annis I., Chen L., Barany G. J. Am. Chem. Soc. 1998, 120, 7226.

36. Bartholomew M. Sefton Current Protocols in Cell Biology 1998. Unit 14.1

37. Hunter T. Cell. 1995, 80, 225.

38. Tóth G.K., Kele Z., Váradi G. Current Organic Chemistry 2007, 11, 180.

39. McMurray J.S., Coleman D.R., Wang W., Campbell M.L. Biopolymers 2001, 60, 3.

40. Perich J.W., Ruzzene M., Pinna L.A., Reynolds E.C. Int. J. Pept. Prot. Res. 1994, $43,39$.

41. Kupihár Z., Kele Z., Tóth G.K. Org. Lett. 2001, 3, 1033.

42. Kitas E.A., Wade J.D., Johns R.B., Perich J.W., Tregear G.W. J. Chem. Soc. Chem. Commun. 1991, 338.

43. Wade J.D., Bedford J., Sheppard R.D., Tregear G.E. Pept. Res. 1991, 4, 194.

44. Xu Q.H., Ottinger E.A., Sole N.A., Barany G. Lett. Pept. Sci. 1997, 3, 333.

45. Kupihár Z., Váradi G., Monostori E., Tóth G.K. Tetrahedron Lett. 2000, 41, 4457. 
46. Dallman M.F., Ahana S.F., Cascio C.S., Darlington D.N., Jacobson L., Levin N. Recent Prog. Horm. Res. 1987, 43, 113.

47. Vale W., Spiess J., Rivier C., Rivier J. Science 1981, 213(4514), 1394.

48. Lewis K., Li C., Perrin M.H., Blount A., Kunitahe K., Ponardson C., Vaughan J., Reyes T.M., Gulyas J., Fischer W., Bilezikjian L., Rivier J, Sawchen P.E., Vale W.W. Proc. Natl. Acad. Sci. USA 2001, 98(13), 7570.

49. Hsu S.Y., Hsu A.J. Nat. Med. 2001, 7, 605.

50. Zorilla E.P., Koob G.F. Expert. Opin. Investig. Drugs 2004, 13, 799.

51. Venihaki M., Sakihara S., Subramanian S., Dikkes P., Weniger S.C., Liapakis G., Graf T.T., Majzonb J.A., J. Neuroendocrinology 2004, 16, 411.

52. Amat J., Tamblym J.P., Paul E.D., Bland S.T., Amat P., Foster A.C., Watkins L.R., Meier S.F. Neuroscience 2004, 129, 509.

53. Sakurai T., Amemiya A., Ishii M., Matsuzaki I., Chemelli R.M., Tanaka H., Williams S.C., Richardson J.A., Kozlowski G.P., Wilson S., Arch J.R.S., Buckingham R.E., Haynes A.C., Carr S.A., Annan R. S. , McNulty D.E., Liu W., Terrett J.A., Elshourbagy N.A., Bergsma D.J., Yanagisawa M. Cell. 1998, 92(73), 585.

54. Jászberényi M., Bujdosó E., Pataki I., Telegdy G. J. Neuroendocrinology 2000, $12,11174$.

55. Telegdy G., Adamik A. Regulatory Pept. 2002, 104, 105.

56. Medzhitov R., Janeway C.A. Jr. Current Opinion in Immunology 1997, 9, 4.

57. Chandy K.G., DeCoursey T.E., Cahalan M.D., McLaughlin C., Gupta S. J. Exp. Med. 1984, 160, 369.

58. Leonard R.J., Garcia M.L., Slaughter R.S., Reuben J.P. Proc. Natl. Acad. Sci. USA 1992, 89, 10094.

59. Lewis R.S., Cahalan M.D. Annual Rev. Immunol. 1995, 13, 623.

60. Lewis R.S., Annual Rev. Immunol. 2001, 19, 497.

61. Chandy K.G., Wulff H., Beeton C., Pennington M., Gutman G.A., Cahalan M.D. Trends Pharmacol. Sci. 2004, 25, 280.

62. Panyi G., Varga Z., Gáspár R. Immunol. Lett. 2004, 92, 55.

63. Erdei A., Andreev S., Pecht I. Int. Immunology 1995, 7(9), 1433. 
64. Erdei A., Tóth G.K., Andrásfalvy M., Matkó J., Bene L., Bajtay Zs., Ischenko A., Rong X., Pecht I. Immunology Letters 1999, 68(1), 79.

65. Andrásfalvy M., Péterfy H., Tóth G.K., Matkó J., Abramson J., Kerekes K., Vámosi Gy., Pecht I., Erdei A. The Journal of Immunology 2005, 175, 2801.

66. Erdei A., Andrásfalvy M., Péterfy H., Tóth G., Pecht I. Immunology Letters 2004, $92,39$.

67. Barford D., Neel B.G. Structure 1998, 6(3), 249.

68. Holgado-Madruga M., Emlet D.R., Moscatello D.K., Godwin A.K., Wong A.J. Nature 1996, 379, 560.

69. Hof P., Pluskey S., Dhe-Paganon S., Eck M.J., Shoelson S.E. Cell 1998, 92(4), 441.

70. Zhang S.Q., Yang W., Kontaridis M.I., Bivona T.G., Wen G., Araki T., Luo J., Thompson J.A., Schraven B.L., Philips M.R., Neel B.G. Mol. Cell 2004, 13(3), 341.

71. Cunnick J.M., Mei L., Doupnik C.A., Wu J. J Biol Chem. 2001, 276(26), 24380.

72. Koncz G., Tóth G.K., Bökönyi G., Kéri G., Pecht I., Medgyesi D., Gergely J., Sármay G. Eur J Biochem. 2001, $268(14), 3898$.

73. Patent AU2006225288; US2006003937

74. Tanaka M., Telegdy G. Brain Res. Bulletin 2008, 75, 509.

75. Tanaka M., Telegdy G. Brain Res. Bulletin 2008, 77, 301.

76. Patil B.S., Vasanthakumar G.R., Sureshbabu V.V. J. Org. Chem. 2003, 68, 7274.

77. Dutta A.S., Morley J., J. Chem. Soc., Perkin Trans. 1 1975, 1712.

78. Nowick J.S., Holmes D.L., Noronha G., Smith E.M., Nguyen T.M., Huang S.J. J. Org. Chem. 1996, 61, 3929.

79. Sureshbabu V.V, Chennakrishnareddy G., Narendra N., Tetrahedron Lett. 2008, 49, 1408.

80. Myers A.C., Kowalski J.A., Lipton M.A. Bioorg. Med. Chem. Lett., 2004, 14, 5219.

81. Chong P.Y., Petillo P.A. Tetrahedron Lett. 1999, 4501.

82. Chong P.Y., Janicki S.Z., Petillo P.A. J. Org. Chem. 1998, 63, 8515.

83. Gante J. Synthesis 1989, 405. 
84. Ragnarsson U. Chem. Soc. Rev. 2001, 30, 205.

85. Le Berre A., Porte C. Bull. Soc. Chim. Fr. 1978, 11-12 (Part 2), 602.

86. Gray C.J., Quibell M., Jiang K.-L., Baggett N. Synthesis 1991, 141-146

87. Gray C.J., Quibell M., Baggett N., Hammerle T. Int. J. Peptide Protein Res. 1992, 40,351 .

88. Gray C.J., Ireson J.C., Parker R.C. Tetrahedron 1977, 33, 739.

89. Söll R., Beck-Sickinger A. J. Pept. Sci. 2000, 6, 387.

90. Radács M., Molnár A.H., László F.A., Varga C., László F., Gálfi M. J. Mol. Neurosci. 2010, 42(1), 59.

91. Nagyéri G., Gálfi M., Radács M., Molnár A.H., László F., László F.A. Regul. Pept. 2009, 155(1-3), 76.

92. Radács M., Gálfi M., Nagyéri G., Molnár A.H., Varga C., László F., László F.A. Regul. Pept. 2008, 148, 1.

93. Bagdány M., Batista C.V.F., Valdez-Cruz N.A., Somodi S., Rodríguez de la Vega R.C., Licea A.F., Varga Z., Gáspár R., Possani D.L., Panyi G. Molec. Pharmac. 2005, 67, 1034 .

94. Panyi G., Possani L.D., Rodriguez de la Vega R.C., Varga Z., Gáspár R. Current Pharmaceutical Design 2006, 12, 2199.

95. Batista C.V.F., Gómez-Lagunas F., Rodríguez de la Vega R.C., Hajdu P., Panyi G., Gáspár R., Possani D.L. Biochimica et Biophysica Acta 2002, 1601, 123.

96. Sármay G, Angyal A, Kertész A, Maus M, Medgyesi D. Immunol Lett. 2006, 104(1-2), 76 .

97. Kertész A., Takács B., Váradi G., Tóth G.K., Sármay G., Ann N.Y. Acad Sci. 2006, 1091, 437.

98. Jiang Y., Breslav M., Khare R.K., McKinney A., Becker J.M., Naider F. Int. J. Pept. Prot. Res. 1995, 45, 106.

99. Santiveri C.M., Rico M., Jiménez M.A. Protein Sci. 2000, 9, 2151.

100. Santiveri C.M., Pantoja-Uceda D., Rico M., Jiménez M.A. Biopolymers 2005, 79, 150.

101. De Alba E., Jiménez M.A., Rico M., Nieto J.L. Folding \& Design 1996, 1, 133.

102. Ramirez-Alvarado M., Blanco F.J., Serrano L. Nat. Struct. Biol. 1996, 3, 604. 
103. Neidigh J.W., Fesinmeyer R.M., Andersen N.H. Nat. Struct. Biol. 2002, 9, 425.

104. Colombo G., Roccatano D., Mark A.E., Proteins: Structure, Function, and Genetics 2002, 46, 380.

105. Hudáky P., Stráner P., Farkas V., Váradi G., Tóth G.K., Perczel A., Biochemistry 2008, 47, 1007.

106. Kerékgyártó J., Ágoston K.. Batta G.., Kamerling J.P., Vliegenthart J.F.G. Tetrahedron Lett. 1998, 39, 7189.

107. Rabanal F., Pastor J.J., Nicolás E., Albericio F., Giralt E. Tetrahedron Lett. 2000, $41,8093$.

108. Rabanal F., Albericio F., Giralt E. Tetrahedron 1995, 51(5), 1449.

109. Kaiser E., Colescott R.L., Bossinger C.D., Cook P. Anal. Biochem. 1970, 34, 595.

110. Kaiser E., Bossinger C.D., Colescott R.L., Olser D.B. Anal. Chem. Acta. 1980, 118,149 .

111. Tam J.P., Heath W.F., Merrifield R.B. J. Am. Chem. Soc. 1986, 105, 6442.

112. Aberico F., Kneib-Cordonier N., Biancalana S., Gera L., Masada R.I., Hudson D., Barany G. J. Org. Chem. 1990, 55, 3730.

113. Gairi M.I., Lloyd-Williams P., Albericio F., Giralt E. J. Am. Chem. Soc. 1995, 89, 181. 


\section{Összefoglalás}

Doktori munkám eredményeit összefoglalva elmondható:

- Előállítottam a stresszválasz szabályozásában hatékonyan résztvevő urokortin 3 (Ucn 3) neuropeptidet, valamint fragmenseit. Ezen fragmenseket emelt keresztlabirintus (EPM) és módosított erőltetett úszás tesztekben (FST) vizsgáltuk. A molekula antidepresszáns és anxiolitikus hatásáért felelős aktív centrumának az Ucn $3 C$-terminálisán elhelyezkedő Ala-Gln-Ile- $\mathrm{NH}_{2}$ tripeptidet találtuk.

- Az Uen 3 (36-38) szekvencia alapján több mint 20, nagyobb részben peptidomimetikum származékát terveztem és állítottam elő. Ezen analógok biológiai vizsgálat során megállapítottuk, hogy némelyik peptid orális adagolásra is alkalmas.

Az Ucn 3 fragmenseinek és analógjainak előállítása és terápiás felhasználhatósága depresszió és szorongás kezelésében szabadalmi védelem alatt áll.

- Az orexin A szintéziséhez optimalizáltam az „oxidatív folding” körülményeit és egy szilárd hordozóhoz kötött oxidálószert - a Clear-ox ${ }^{\mathrm{TM}}$ gyantát - használva mintegy két óra alatt izolálható volt a natív izomer, mint fő reakciótermék. Megállapítottuk, hogy az orexin A-t közvetlenül agykamrába adva fokozódik a patkányok táplálék- és vízfelvétele és nő a vizeletürítésük. Az eredmények alapján feltételezhetően a polidipszia ill. a poliuria a vazopresszin rendszertől függetlenül jön létre. Az in vitro vizsgálatok eredményei felvetik azt a lehetőséget, hogy a vazopresszin kiválasztást növelő anyagok (állapotok) hatásának orexin okozta mérséklődése szerepet játszhat a polidipszia, poliuria kifejlődésében.

- A természetes és adaptív immunrendszer közötti jelátviteli folyamatokban szelektíven ható szintetikus peptideket állítottam elő, amelyek különböző immunológiai betegségekre ható gyógyszer-készítmények fejlesztésének alapját képezhetik:

- Ma már számos kísérlet bizonyítja, hogy a T-sejt aktivációhoz szükséges $\mathrm{Ca}^{2+}$ jel létrehozásában kulcsszerepet betöltő $\mathrm{K}^{+}$csatornák gátlásán keresztül a T-sejtek proliferációja in vitro és in vivo is gátolható. Munkám során anuroctoxin és Tc32 skorpió peptid toxinokat állítottam elö, amelyek nagy affinitással kötődnek egyes csatornákhoz. 
○ Az anuroctoxin (AnTx) esetében kíváló szelektivitással állítottam elő a natív izomert és optimalizáltam az oxidáció körülményeit. Biológiai mérésekkel igazoltuk, hogy a lineáris peptid legnagyobb része már egy óra után a helyes konformációs formában található, valamint, hogy a szintetikus és natív toxin elektrofiziológiai tulajdonságai teljesen megegyeznek. Az AnTx már 730 pM-os koncentrációban gátolja a Kv1.3 csatornát, ennek ellenére nem elég szelektív, hiszen kisebb affinitással ugyan, de gátolja a Kv1.2 csatornát is.

○ Előállítottam az AnTx több analógját a Kv1.3 ioncsatorna korábbiaknál szelektívebb gátlása céljából. Az egyszeres és kétszeres pontmutációkat tartalmazó peptidek biológiai eredményei azt mutatják, hogy mindhárom toxin (AnTx F32T, AnTx F32T K16D, AnTx F32T N17A) szelektivitása nagy mértékben javult a vad-típusúhoz képest, ugyanakkor a Kv1.3 iránti affinitásuk kis mértékben csökkent. A legjobb tulajdonságú toxin (AnTx F32T N17A) 1 nM-os koncentrációban a Kv1.3 csatornák mintegy 50\%-át gátolta, míg a Kv1.2 csatornákon még 100 nM-os koncentrációban sem volt mérhető hatása. A továbbiakban az általunk először elöállított toxinok vizsgálata a cél, hiszen a tripla ill. többszörös mutánsok remélhetőleg mind affinitásban, mind szelektivitásban felülmúlják a natív toxint, így újabb potenciális terápiás felhasználás lehetőségét kínálják autoimmun betegségek kezelésében.

○ A Tc32 peptid toxin „oxidatív folding”-gal és konvergens szintézissel végzett előállítása nem a megfelelő diszulfid híd mintázattal rendelkező izomert eredményezte. A lépésenkénti regioszelektív cisztein párosítások módszere sem hozta a kellő szelektivitást, mert a választott védőcsoportok egyike nem teljesítette az ortogonalitás feltételeit. A $\mathrm{StBu}$ csoport hasítását szilárd fázison az irodalomból ismert módszerekkel nem sikerült megvalósítani, így a későbbiekben az oldat fázisban szabad tiol csoportokkal végrehajtott hasítás a diszulfid hidak keveredését eredményezhette. A különböző szintézisek főterméke mindig egyazon izomert eredményezte, mely nem azonos a natív izomerrel, ezen eredmények alapján felmerül a diszulfid hidak helyének meghatározási pontossága. A továbbiakban tervezzük újabb ortogonális védőcsoport kombináció kipróbálását a lépésenkénti regioszelektív cisztein párosítások módszerével a fenti feltételezésünk igazolására. 
○ Előállítottam rendkívül jó hozammal, lépésenkénti regioszelektív cisztein párosítások módszerével a C3a9 szekvencia szimmetrikus dimerjét annak a feltételezésnek az igazolására, hogy az allergiás reakciók gátlásáért a C3a9 peptid intermolekuláris diszulfid hidakkal stabilizált dimer formája a felelős. A dimer tesztelése biológiai rendszerekben folyamatban van.

○ Előállítottam a Gab1 adapter fehérje eredetü GDLDpe (621-633) szekvenciáját, valamint ennek rövidebb foszfopeptid fragmenseit és módosított változatait. A foszfatáz aktivitás méréshez ill. a különböző jelátviteli molekulákhoz való kötődési vizsgálatokhoz biotinnal jelöltem a peptideket A kiválasztott Gab1-peptidek sejtbe juttatásához $N$ terminálisan oktanoil-R8C peptidet kapcsoltam egy hosszabb szénláncot tartalmazó távolságtartón keresztül. Az eredmények alapján úgy gondoljuk, hogy a sejtpermeábilis foszfopeptidek képesek gátolni a Gab1/SHP-2 és Gab1/PI3-K fehérje kölcsönhatások kialakulását és ezáltal módosíthatják a proliferációs, apoptotikus és túlélési szignálokat.

- $\beta$-modellpeptideket (SETE-peptidek) és minifehérjéket (Betanova, Tc5b foszfo- és glikoanalógjai) is előállítottam és vizsgáltuk ezek konformációs egyensúlyát. Megállapítható, hogy ezen peptidek belső mozgékonysága még mindig jelentős, tehát szükség van további módosításokra egy még stabilabb szerkezet eléréséhez. A vizsgált modellpeptidek nem rendelkeznek egyetlen, helyesen jellemezhető téralkattal, azonban sikerült leszükíteni a lehetséges szerkezetek számát SETE-S3E modellpeptid esetében. Ez a peptid a továbbiakban hasznos modellként szolgálhat $\beta$-hairpin rendszerek tanulmányozására.

Az eredmények azt mutatják, hogy a körültekintően kiválasztott szintézismódszerek segitségével sikerült olyan módositott biológiailag aktív peptideket elöállítani, amelyek növelt szelektivitással rendelkeznek, ill. általuk fokozható a natív szekvenciák biológiai hatása. Piackutatási tanulmányok adatai szerint az elmúlt években újra fokozott érdeklödés mutatkozik a peptidalapú hatóanyagok iránt, tehát a módositott biológiailag aktív peptidek jó eséllyel vetélytársai a szintetikus gyógyszerjelölt kismolekuláknak. 


\section{Summary}

Summaryzing my doctoral work, I achieved the followings:

- The urocortin 3 (Ucn 3) neuropeptide and its fragments with targeted deletion of amino acids were synthesized. These peptides were tested in elevated-plus-maze test (EPM) and modified forced swimming test (FST). The active center of the molecule that preserves the antidepressive and anxiolytic action of the longer sequence was found to be the $C$-terminal Ala-Gln-Ile- $\mathrm{NH}_{2}$ tripeptide. On the basis of this Ucn 3 (36-38) sequence, I designed and synthesized more than 20, mainly peptidomimetic analogues. Most of these analogues have been investigated in biological tests and some of them showed to be suitable even for oral administration.

The preparation and the potential use in therapy of depression and anxiety of the Ucn 3 fragments and analogues are protected by our Hungarian and international patents.

- The oxidative folding conditions for the synthesis of orexin A were optimized. The native isomer can be isolated as the major reaction product by using a polymer-supported oxidant the Clear-ox ${ }^{\mathrm{TM}}$ resin within two hours. The effect of Orexin A was tested on water metabolism in vivo and on vasopressin secretion in vitro. It was found that intracerebroventricular (i.c.v.) administration of orexin A enhanced the food- and waterintake and urination of rats. According to our results, polidipsia and poliuria presumably are independent of the vasopressin-system. Results of in vitro experiments suggested that moderating the effect of compounds that increase vasopressin secretion with orexins could have a role in development of polidipsia, poliuria.

- Peptides that can selectively act in the signal transduction pathways between the innate and adaptive immune system were synthesized. They can serve as potential drug candidates in treating different immunological diseases:

- Several studies in vivo and in vitro underlie the essential role of $\mathrm{K}^{+}$channel blockers in prevention of T-cell activation and proliferation through the $\mathrm{Ca}^{2+}$ signal. In my work, I focused on the synthesis of anuroctoxin (AnTx) and Tc32.

- The AnTx was synthesized with high selectivity, and the folding conditions were optimized. The majority of the linear peptide folds in cyclic form with all four disulfide 
bonds in the correct form within 1 hour. The regioselectivity was verified with measurements that prove the identity of the electrophysiological properties of the native and synthetic toxin. The AnTx blocks the Kv1.3 channel in 730 pM concentration, although AnTx is not selective enough since it also blocks the Kv1.2 channels with smaller affinity than Kv1.3 channel.

Analogues of AnTx were designed to increase the inhibition selectivity for the Kv1.3 ion channels. Results of biological measurements of analogues with single or double point mutation show that selectivity of all three toxins (AnTx F32T, AnTx F32TK16D, AnTx F32T N17A) are increased compared to the wild-type toxin, and their affinity to the Kv1.3 channels slightly decreased. AnTx F32T N17A, the most effective toxin blocks $50 \%$ of the Kv1.3 channels in $1 \mathrm{nM}$ concentration, while it has no effect on the Kv1.2 channels in $100 \mathrm{nM}$ concentration.

Further measurements are needed to prove that the double, triple, and multiple mutants of the prepared analogues surpass both the affinity and selectivity of the native toxin, and accordingly, they enhance the possibility of their therapeutical use in treating autoimmune diseases.

- The preparation of Tc32 with oxidative folding and convergent synthesis did not resulted in peptides with the desired disulfide bridges. The product of the stepwise, regioselective cysteine pairings method did not show the selectivity, because one of the chosen protecting groups did not fulfiled the required orthogonality. The cleavage of the $\mathrm{St} \mathrm{Bu}$ group failed in solid-phase with the methods known from the literature. The cleavage of the $\mathrm{S} t \mathrm{Bu}$ group in liquid phase with compounds having free tiol group could have caused a scrambling of the disulfide bridges. According to the biological results, the different synthetic methods resulted in the same inactive isomer as main product. This points to presumably innacurate previous determination of the disulfide bridge connections in the toxin Tc32. Henceforward, we plan another protecting group scheme with stepwise regioselective cysteine pairings method to prove our presumption.

- The C3a peptide blocks the activation of the mucosal type of mast cells and the release of the content of the granules such as histamine that cause immediate hypersensitivity (allergic reaction). 
In order to prove the presumption, that the dimeric form of $\mathrm{C} 3 \mathrm{a} 9$ stabilized by intermolecular disulfide bridges is responsible for the inhibition of allergic reactions, the symmetrical dimer of the $\mathrm{C} 3 \mathrm{a} 9$ peptide was synthesized with the stepwise regioselective cysteine pairings method in high yield. The testing of the dimer compound in biological systems is in progress.

- The SHP-2 phosphatase has positive regulatory function in cell growth and hence this enzyme might be attractive target in the therapy of malignant cell growth. Our main goal was to synthesize cell membrane permeable phosphopeptides („,baits”) that could inhibit the growth of tumors.

The GDLDpe (621-633) peptide that is derived from the Gab1 adaptor protein and its shorter fragments and modified sequences were prepared. Biotinylated peptides were used for measurements of the phosphatase activity. In order to transport the chosen Gab1 derived peptides into the living cells, they were conjugated with membrane permeable carriers through a linker (octanoyl-R8C). Our results suggests that the cell penetrating phosphopeptides may regulate the Gab1/SHP-2 and Gab1/PI3-K interactions and modulate intracellular signaling that lead to cell proliferation and cell survival.

- $\beta$-model peptides (SETE-peptides) and miniproteins (Betanova, some glyco- and phospho-analogues of $\mathrm{Tc} 5 \mathrm{~b}$ ) were also synthesized. We found that these peptides still show significant mobility. Accordingly, further modification is needed in order to obtain a more stable structure. A single structure can not correctly describe these model peptides, however we managed to restrict the number of possibilities for the SETE-S3E peptide. This peptide could serve hereafter as a useful model for $\beta$-hairpin studies.

Our results prove that modified biologically active peptides with greater selectivity and improved activities of the native sequences can succesfully be synthesized by careful selection of the synthetic methods. Recent studies on market research show that the potential use of peptide therapeutics has increased, so the modified biologically active peptides can be valuable alternatives of the small synthetic drug candidates. 


\section{Köszönetnyilvánítás}

Köszönetemet szeretném kifejezni Prof. Tóth Gábornak egyrészt mint témavezetőmnek, hogy néhány évnyi munkám alatt annyi mindent átadott sokévi tapasztalatából, tudásából, másrészt mint intézetvezetőnek, hogy lehetőséget biztosított az SZTE ÁOK Orvosi Vegytani Intézetében a doktori munkám elvégzéséhez.

Köszönettel tartozom az SZTE TTIK Kémia Doktori Iskolának, hogy a Bioorganikus Kémia doktori program keretein belül lehetőséget kaptam a Ph.D. fokozat megszerzésére. A biológiai mérésekért köszönettel tartozom Prof. Telegdy Gyulának, Prof. Ferenc Lászlónak, Prof. Panyi Györgynek, Prof. Sármay Gabriellának, Prof. Erdei Annának és munkatársaiknak, az NMR- és CD-spektroszkópiai mérésekért Prof. Perczel Andrásnak és munkatársainak.

Külön köszönettel tartozom Dr. Zarándi Mártának a sok hasznos tanácsért amellyel hozzájárult a doktori értekezésem elkészítéséhez.

Köszönöm labortársaimnak, Dósai Molnár Évának, Nagy Katalinnak, Szolomájer-Csikós Orsolyának, Hegyi Orsolyának, Váradi Györgyinek és a többieknek, akik a szakmai segítségen túl emberileg is sokat nyújtottak számomra az elmúlt években.

Köszönöm továbbá az Orvosi Vegytani Intézet összes munkatársának a segítséget és a felejthetetlen hangulatot.

Végül, de nem utolsó sorban szeretném férjemnek, családomnak megköszönni a türelmet, támogatást, szeretet, amivel tanulmányaimat segítették. 